\title{
Competing States:
}

The Use of Public Policy by Minority and Majority Nations

by

\section{Alexandre Couture Gagnon}

A thesis submitted to the Faculty of Graduate and Postdoctoral Affairs in partial fulfillment of the requirements for the degree of

\section{Doctor of Philosophy}

in

\section{Public Policy}

\author{
Carleton University \\ Ottawa, Ontario
}

(C) 2013

Alexandre Couture Gagnon 


\section{Abstract}

Since the mid-1900's, minority nationalistic movements within larger states have grown throughout the industrialized world. The rise of these minority nations' consciousness confronts their respective majority nation's self-definition. Within a given country, both the minority nation and the majority one thus engage in competition for loyalty. This competition is played out at the level of the state, that is, the minority nation's and the majority nation's governments fight for their citizens' loyalty through public policies. In order to study this phenomenon, this dissertation examines two case studies: Catalonia in Spain and Québec in Canada. A model has been developed to describe the dynamics of competition via public policy between the minority nation and the majority nation.

Three policy areas are studied: language, foreign affairs, and immigration policy. The key element to the competition between the minority nation and the majority nation is the incrementalism of the minority nation's request for more power from the majority nation. The smaller the change required, the more the minority nation gains in the long term. Confrontation between a minority nation's and a majority nation's governments will take place when a government thinks that it has an advantage or when it wants to advance a public policy in a significant manner. Macro-confrontation, that is, confrontation across policy fields, happens around referendums on sovereignty and periods of high political tension.

This research's objective is two-fold. First, it portends to describe competition between the minority nation's and its respective majority nation's governments over the 
citizens' loyalty through public policies. Second, it asserts that the competition may be modeled for most industrialized federal states. 


\section{Acknowledgements}

Writing this thesis was challenging both intellectually and emotionally. It would have taken longer and the quality would be lesser without the support from dedicated professors, the financial support from organizations, and my family.

It will never be possible to thank Leslie Pal enough for his supervision of my thesis. I cannot imagine the suffering associated with reading the numerous drafts of badly-written chapters with ideas that did not hold together. It is impressive that someone could succeed at providing comments that allowed the improvement of what ended up a dissertation without becoming discouraged or without discouraging the student. On top of that, Dr. Pal wrote many, (many, many!) recommendation letters and filled out no small number of scholarship forms. Thank you a thousand times.

Interesting and long conversations occurred with André Lecours and Stanley Winer throughout the writing of this dissertation. Dr. Lecours' knowledge of Spain and autonomous communities was essential to the beginning of this research. Conversations on federalism and the tensions between Madrid and Barcelona were enlightening and, without these, this dissertation would have missed important facts. Dr. Winer's interest for rational models kept my interest and confidence that I could structure my own ideas. I would have given up the model in this dissertation had it not been for the book recommendations, our lengthy discussions, and just feeling that he thought that I could do it.

Warm thanks go to Tove Malloy and the European Centre for Minority Issues 
(ECMI) in Flensburg, Germany, for welcoming my husband and me during the summer of 2010. The nice working environment as well as the great comments during the workshop in which I participated, made the journey fruitful for my dissertation. What is more, the organized visits to national minorities in the area awakened me to the ways in which Catalonia and, perhaps more, Québec serve as models for other national minorities' aspirations.

The professors at the School of Public Policy and Administration are exceptional. The courses with Frances Abele, Rianne Mahon, Phil Ryan, and Saul Schwartz were particularly important for widening my horizons and helping me learn how to write academically. Formative teaching assistantships took place with Allan Maslove and Stephan Schott. Graeme Auld made the organization of the First David Wink SPPA Ph.D. Conference, with Nick Falvo, easy and fun. Many short and long talks happened in hallways with other faculty members (Calum Carmichael, Marc-André Gagnon, Alexandra Mallett, and Jennifer Stewart) who showed genuine interest.

Thank you to Donna Patrick at the School of Canadian Studies at Carleton University for conversations early in the research process and the great course on Language, Culture, and Power in Canada.

Thank you very much to the amazing personnel at the School of Public Policy and Administration (SPPA) at Carleton University: Meghan Innes, Nicki Enouy, Tabbatha Malouin, and Mary Au. From helping with scholarship deadlines, academic registration, to organizing a students' conferences, I always felt - and tested a few times - that they genuinely cared and wanted me to finish a great dissertation. 
Merci à la professeure Lynda Khalaf du Département d'économique de l'Université Carleton pour l'accueil chaleureux (et le délicieux café) ainsi que les conseils judicieux dans les moments difficiles des premières années du doctorat.

Merci au professeur James Meadowcroft et à Stephanie DuRant pour les encouragements, les bons repas et les discussions fascinantes.

Merci à mes anciens professeurs de l'École nationale d'administration publique, en particulier Luc Bernier et Filip Palda, qui ont toujours eu à coeur mon succès et ont guidé mes décisions académiques, bien après mes études à Québec.

Moltes gracies a la Thaïs Martín per a les classes de català. Gràcies a vostè, vaig aprendre molt sobre la cultura catalana i això em va ajudar amb les entrevistes a Barcelona.

Thank you to Jenn Hartzog for the amazing proof-reading. She proof-read the whole dissertation at a fast pace and gave me an advanced English class at the same time. I knew that she cared about my dissertation and felt "en confiance" during the whole process.

The doctoral studies that led to the completion of this dissertation have been funded by the Fonds québécois de la recherche sur la société et la culture (FQRSC), the Social Sciences and Humanities Research Council (SSHRC), and the Ontario Graduate Scholarships (OGS). Moreover, various organizations provided financial help to attend conferences and visit the ECMI, thus fostering the research of this thesis: Carleton University, the Association internationale d'études québécoises (AIEQ), and the Centre 
for European Studies at Carleton University (the latter involving a partial contribution from a European Union grant). Many participants to academic conferences provided thorough comments of parts of this dissertation. Most notably, in 2011, Alain-G. Gagnon invited me at the Séminaire de la relève of the Groupe de recherche sur les sociétés plurinationales (with the collaboration of the Chaire de recherche du Canada en études québécoises et canadiennes), where I was challenged by academics who I admired (Alain Dieckhoff, Alain-G. Gagnon, and Michel Seymour) in a friendly setting; Guy Laforest discussed enthusiastically the chapter on foreign policy at the conference of the Société québécoise de science politique and suggested the concept of macro-confrontation which filled previous gaps in my dissertation. Linda Cardinal engaged me in a very detailed and a helpful conversation of the chapter on linguistic policy.

All incoherences, all mistakes, and all opinions in this dissertation are my sole responsibility.

Sur une note plus personnelle (et je ne m'épancherai pas, vous savez déjà que je suis trop sensible), je dois la fin de ce grand projet d'études à ma famille. Mes grandsparents ont souligné mes moindres succès depuis ma naissance et m'ont toujours enveloppée d'un amour inébranlable. L'un de mes grands-pères m'a donné très jeune envie d'apprendre l'anglais. L'autre de mes grands-pères adore la politique; j'aimerais en connaître autant que lui. Mes grands-mères m'ont souvent raconté qu'elles avaient étudié autant qu'il ne leur était permis à leur époque; ces histoires m'ont donné envie d'aller à l'école aussi longtemps que possible.

Owen chéri, merci pour les discussions intelligentes et critiques, les corrections de 
tonnes de versions et de courriels ainsi que les encouragements quotidiens, même dans les pires épisodes d'abattement. Merci surtout pour l'inspiration journalière.

Chers parents, ah !, je vous dois tout. Vous m'avez donné le goût d'apprendre, payé mes études, encouragée chaque fois que je voulais laisser tomber, instillé la confiance nécessaire à l'achèvement d'un projet de plusieurs années. Votre joie de vivre et l'importance que vous accordez à l'équilibre m'ont permis de demeurer saine d'esprit pendant le doctorat.

Élaine et Serge, je ne pourrai jamais vous remercier de tout ce que vous avez fait pour moi. Vous m'avez accueillie dans les grands stress de fins de session pour des repas de homard; vous avez assisté à la soutenance de mon mémoire; vous m'avez recueillie après mon bénévolat sud-américain. Et vous avez offert votre demeure pour la réception de notre mariage, à Owen et à moi. Maintenant que je suis adulte (!?), vous continuez de m'accueillir. Sans vous, mon parcours universitaire aurait été pénible.

Xav, merci de toutes les copies de ma thèse, de tes excellentes blagues et de prendre soin de mon chat adoré, toujours à la dernière minute. Ton souci du détail, ton perfectionnisme sont au-delà de ce que je ne pourrai jamais atteindre.

Lolo, merci des encouragements à profusion et en continu, même de l'autre bout du monde, de tes notes de cours sur l'ex-URSS et de l'organisation de mes premières entrevues avec tes voisins de bureau de la Catalogne à New York. Ta connaissance du soviétisme et ta maîtrise du russe constituent des preuves que l'adoption d'une sousculture est à portée de la main moyennant un désir profond. 
Merci à Henriette Dumont du Secrétariat du Conseil du trésor du Québec de m'avoir encouragée à poursuivre au doctorat. Dans la même veine, merci à André Plourde pour la poussée bien sentie : « Dans la vie, on ne peut compter que sur soi-même. »

Merci à mes amis, en particulier Helen, Isabelle, Julie, Joël et Myra, pour les moments relaxants, les oreilles empathiques et les encouragements soutenus.

Merci à mon collègue du doctorat, feu David Wink, pour les rires et les discussions pas trop sérieuses pendant la première année. Ta thèse aurait été bien meilleure que celle-ci. 


\section{Table of Contents}

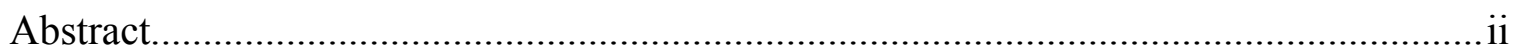

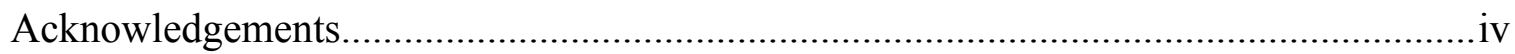

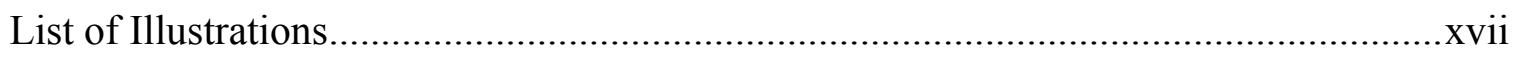

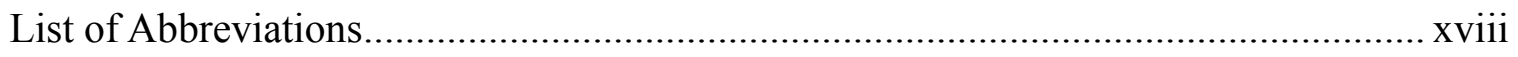

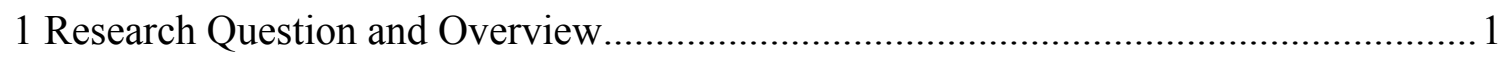

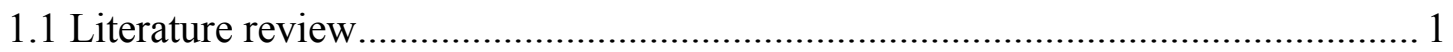

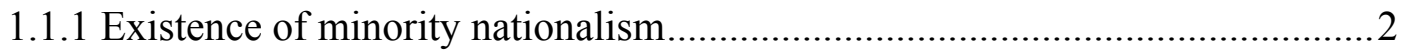

1.1.2 Current situation in Québec-Canada and Catalonia-Spain...............................5

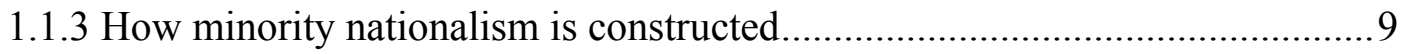

1.1.4 Competing majority and minority nationalisms.......................................... 12

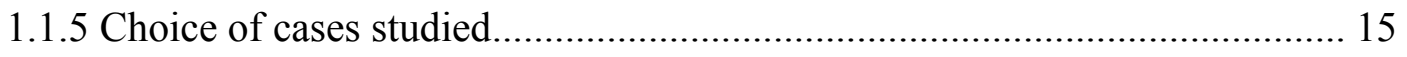

1.2 Layout of the dissertation.................................................................................. 17

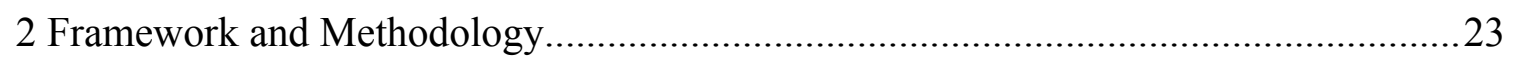

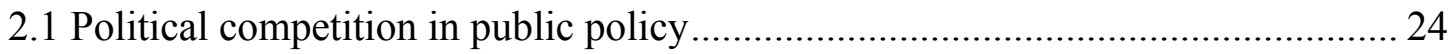

2.1.1 Evolution of minority nationalism...........................................................24

2.1.2 Management of minority nationalism by the majority nation's government..28

2.2 A model of political competition in public policy ................................................34

2.2.1 Definition of "public policy"............................................................................

2.2.2 Governments and citizens' loyalty .................................................................

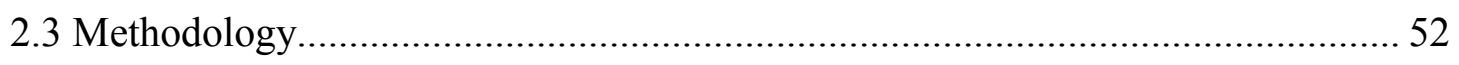

2.3.1 Rationale for the choice of public policies....................................................5 
2.3.2 Classification of the competition via public policies

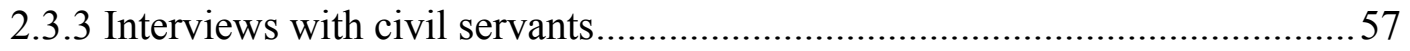

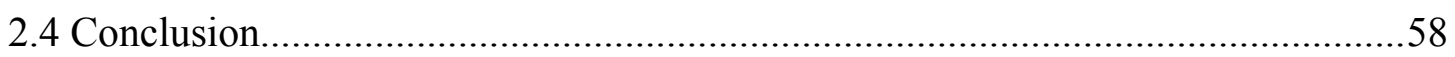

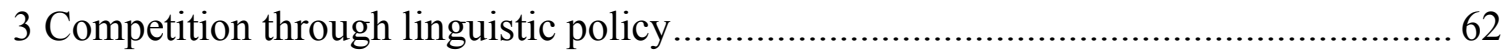

3.1 Linguistic policies in Québec and in Canada................................................... 64

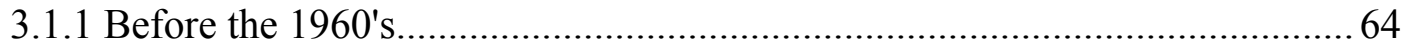

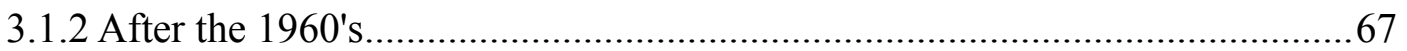

3.1.2.1 Commission royale d'enquête sur l'enseignement dans la province de

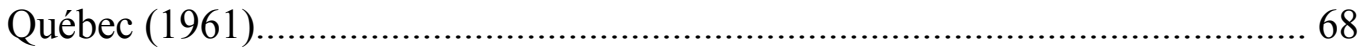

3.1.2.2 Royal Commission on Bilingualism and Biculturalism (1963).............69

3.1.2.3 Crisis of Saint-Léonard (1968-9) ......................................................... 71

3.1.2.4 Commission of Inquiry on the Situation of the French Language and

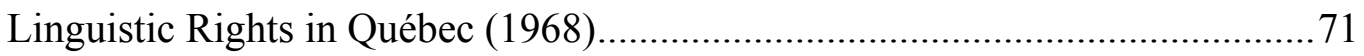

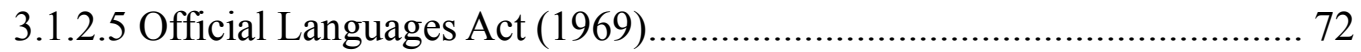

3.1.2.6 Act to promote the French Language in Québec (1969)........................73

3.1.2.7 Policy of Multiculturalism (1971) ................................................. 74

3.1.2.8 Official Language Act (1974) .................................................... 76

3.1.2.9 Charter of the French Language (1977).............................................77

3.1.2.10 Changes to the Charter of the French Language by the Supreme Court

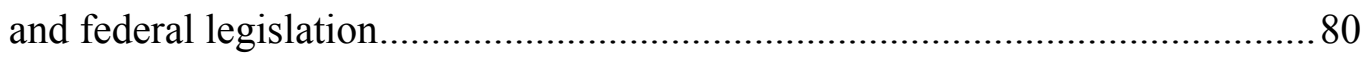

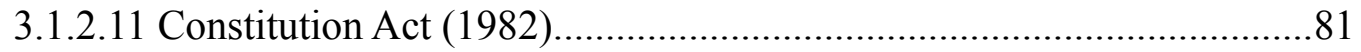

3.1.2.12 Official Languages Act (1985)................................................. 83 


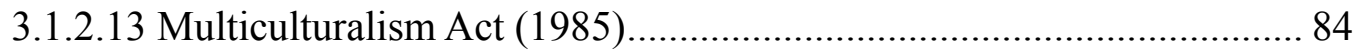

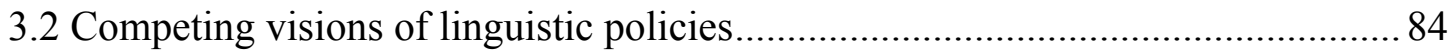

3.2.1 Competition between Québec and Ottawa in linguistic policy......................86

3.3 Linguistic policies in Catalonia and in Spain.......................................................... 89

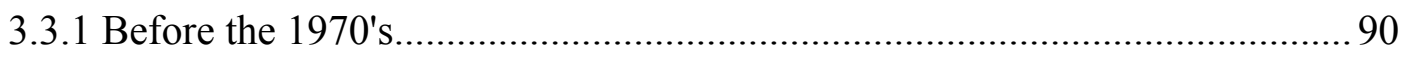

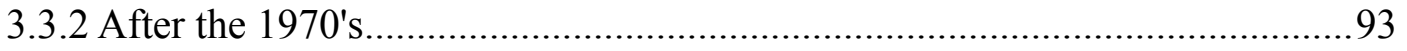

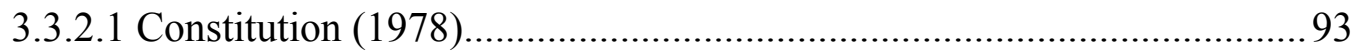

3.3.2.2 Statute of Autonomy (1979)................................................................. 94

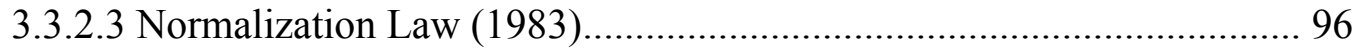

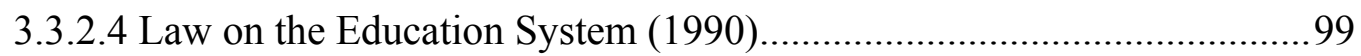

3.3.2.5 Decree that establishes the structure of the mandatory education in

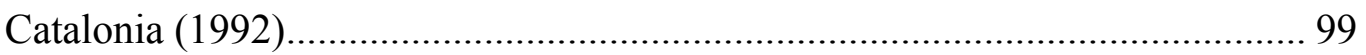

3.3.2.6 Linguistic Policy Act (1998).................................................................. 100

3.3.2.7 European Charter for Regional or Minority Languages (2001) …......102

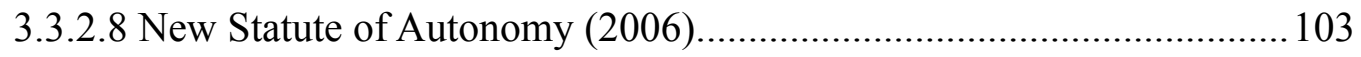

3.3.2.9 Sentence of the Constitutional Court (2010).......................................106

3.4 Competing visions of linguistic policies............................................................. 107

3.4.1 Competition between Barcelona and Madrid in linguistic policy.................108

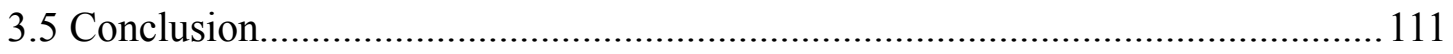

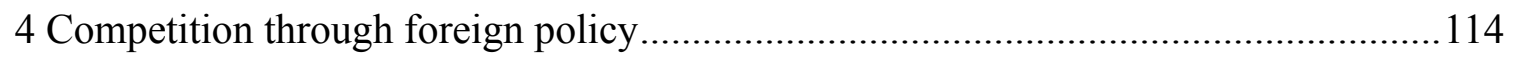

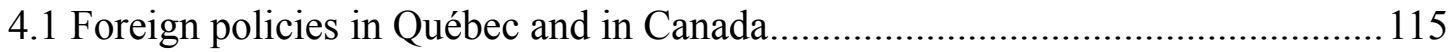

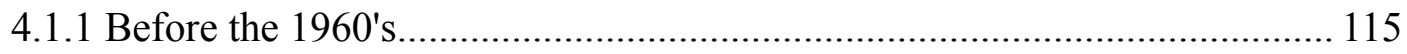




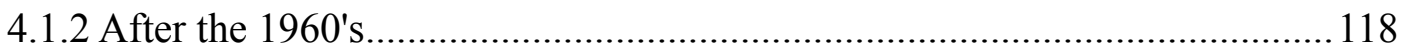

4.1.2.1 Education Agreements with France (1965)...........................................119

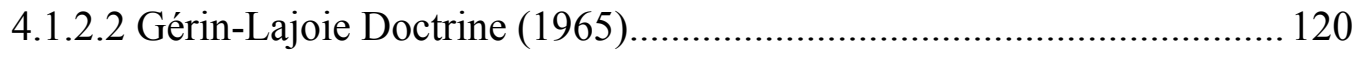

4.1.2.3 Conference of the Ministers of Education of French African Countries in Gabon (1968) and General Conference of the Francophonie in Paris (1968)...122

4.1.2.4 Federalism and International Relations (1968)...................................123

4.1.2.5 Agence de coopération culturelle et technique (1970)..........................125

4.1.2.6 Conférence des chefs d'État et de gouvernement des pays ayant en commun l'usage du français (1985)............................................................... 126

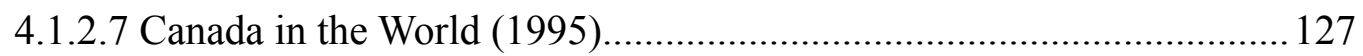

4.1.2.8 Response of the Québec government (1999 to 2002)...........................128

4.1.2.9 Agreement concerning UNESCO (2006)............................................131

4.2 Competing visions of foreign policies.............................................................. 133

4.2.1 Competition between Québec and Ottawa in foreign policy........................133

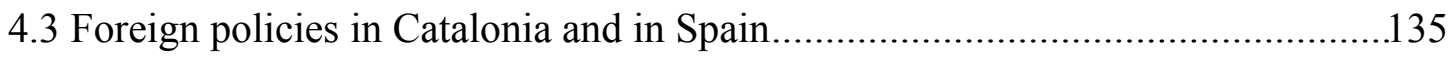

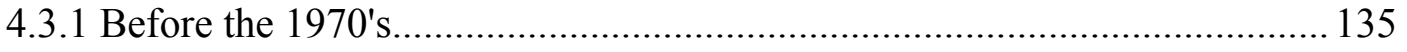

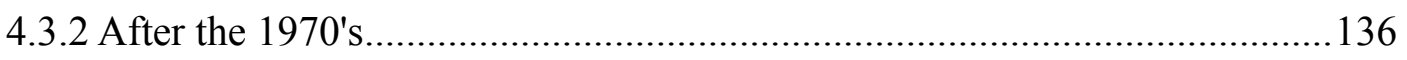

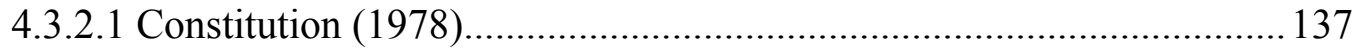

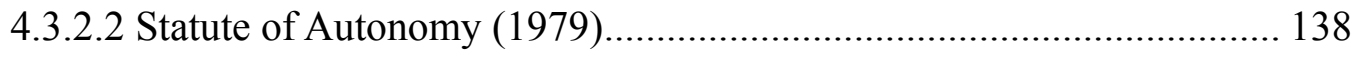

4.3.2.3 Judgment 137 of the Constitutional Court (1989)...............................139

4.3.2.4 Judgment 153 of the Constitutional Court (1989)................................139

4.3.2.5 Treaty of the European Union (1992).................................................. 140 
4.3.2.6 Judgment 165 of the Constitutional Court (1994).

4.3.2.7 Agreement of CARCE on the participation of the AC's in the European

Communities' issues via the sectoral conferences (1994)...... 144

4.3.2.8 Act that regulates CARCE (1997). 144

4.3.2.9 Agreement of CARCE on representation on the EU Council of Ministers (2004) 145

4.3.2.10 Revised Statute of Autonomy (2006)..... 147

4.3.2.11 Judgment of the Constitutional Court (2010). 148

4.4 Competing visions of foreign policy

4.4.1 Competition between Barcelona and Madrid in foreign policy. 150

4.5 Conclusion 153

5 Competition through immigration policy. 156

5.1 Immigration policies in Québec and in Canada 158

5.1.1 Before the 1960 's 158

5.1.2 After the 1960 's. 160

5.1.2.1 Ministère de l'Immigration (1968). 160

5.1.2.2 Cloutier-Lang Agreement (1971) 161

5.1.2.3 Bienvenue-Andras Agreement (1975). 162

5.1.2.4 Immigration Act (1976). 164

5.1.2.5 Couture-Cullen Agreement (1978). 165

5.1.2.6 Immigration Policy (1990). 166

5.1.2.7 Gagnon-Tremblay-McDougall Agreement (1991). 167 
5.2 Competing visions of immigration policies.....

5.2.1 Competition between Québec and Ottawa in immigration policy.

5.3 Immigration policies in Catalonia and in Spain.....

5.3.1 Before the 1970 's 174

5.3.2 After the 1970 's

5.3.2.1 Interdepartmental Immigration Committee (1993). 176

5.3.2.2 Act on Rights and Liberties of Foreigners in Spain and their Social Integration (2000)

5.3.2.3 Secretariat for Immigration (2000) and 2001-2004 Immigration Plan $(2000)$

5.3.2.4 Revised Statute of Autonomy (2006)..... 181

5.3.2.5 National Agreement on Immigration (2008)

5.3.2.6 Citizenship and Immigration Plan (2009). 184

5.3.2.7 Revised Act on Rights and Liberties of Foreigners in Spain and their

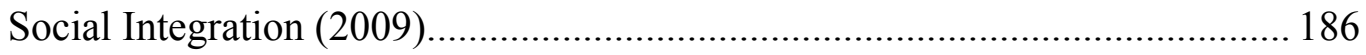

5.3.2.8 Judgment of the Constitutional Court (2010)...................................188

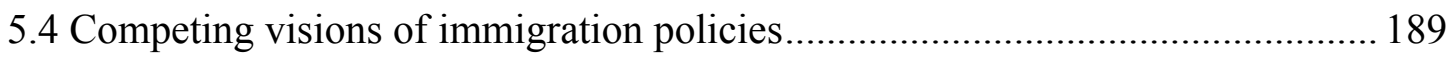

5.4.1 Competition between Barcelona and Madrid in immigration policy ...........190

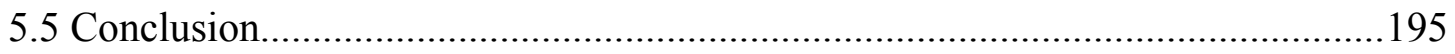

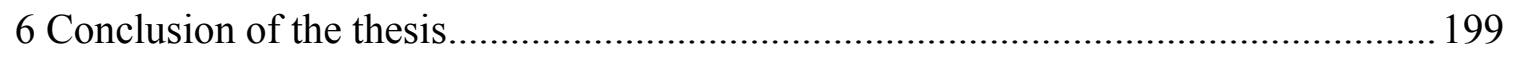

6.1 Importance of the comparison between Catalonia and Québec..........................200

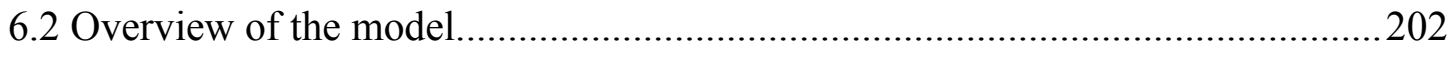




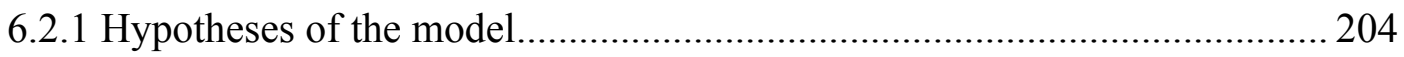

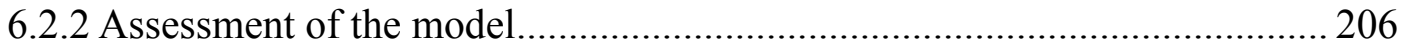

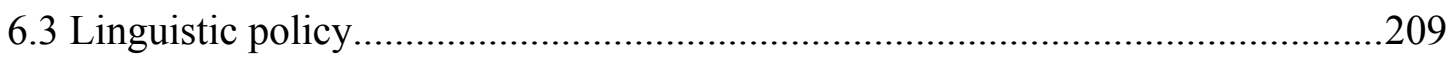

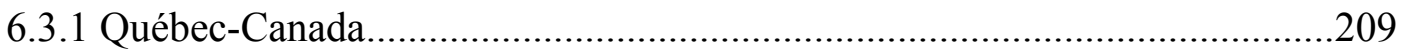

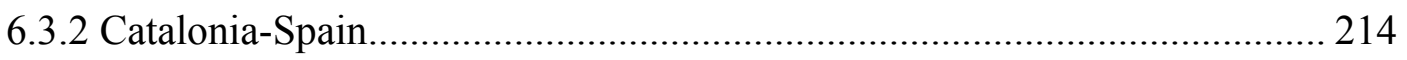

6.3.3 Conclusion on linguistic policy ...........................................................2217

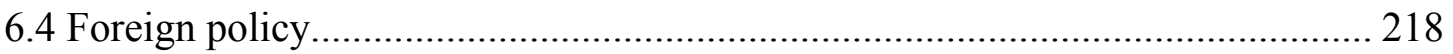

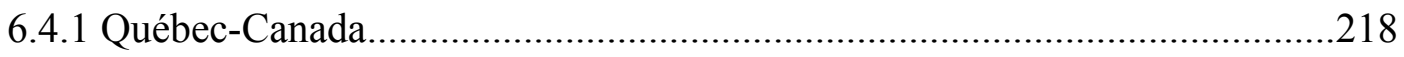

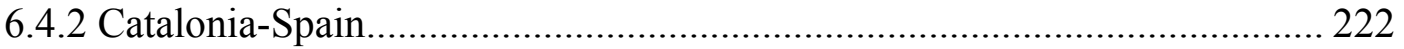

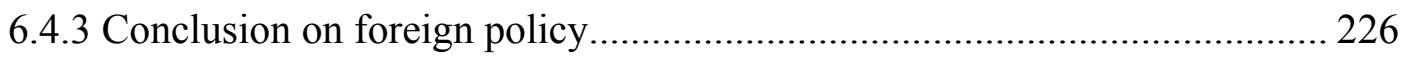

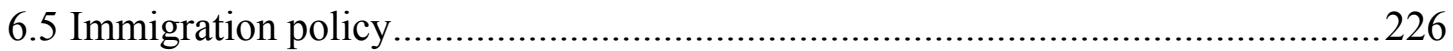

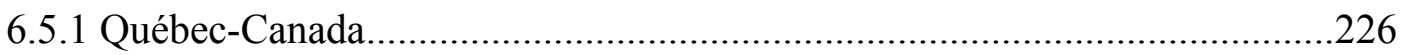

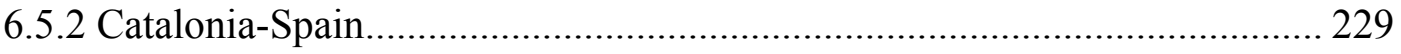

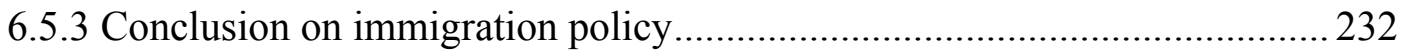

6.6 Current macro-confrontation in Catalonia-Spain...............................................23

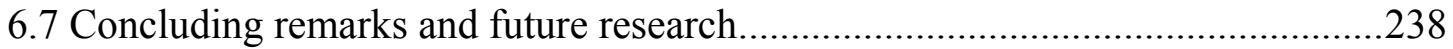

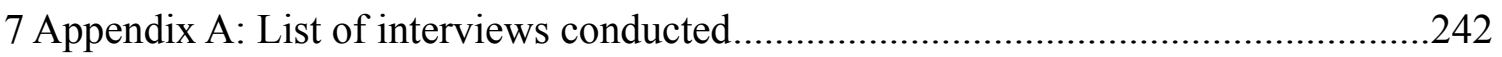

8 Appendix B: Chronologies of Québec-Canada and Catalonia-Spain (accompanying CD

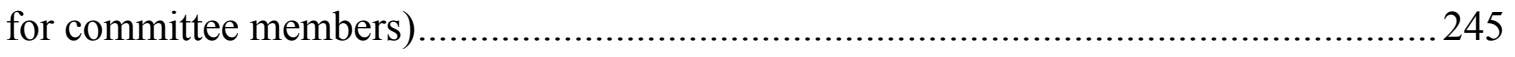

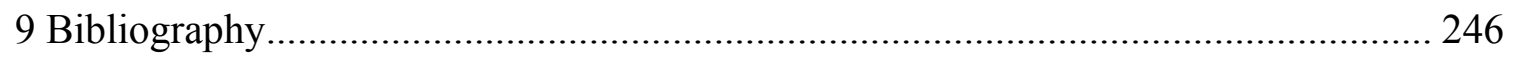




\section{List of Illustrations}

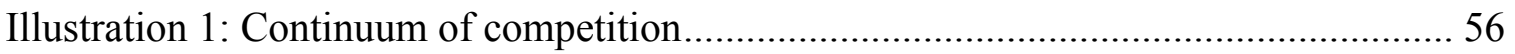

Illustration 2: Time Line of Actions in Linguistic Policy in Québec and Canada..............87

Illustration 3: Time Line of Actions in Linguistic Policy in Catalonia and Spain...........109

Illustration 4: Time Line of Actions in Foreign Policy of Québec and Canada................134

Illustration 5: Time Line of Actions in Foreign Policy of Catalonia and Spain...............151

Illustration 6: Time Line of Actions in Immigration Policy in Québec and Canada.......172

Illustration 7: Time Line of Actions in Immigration Policy in Catalonia and Spain.......191 


\section{List of Abbreviations}

\section{Political parties in Québec and Canada}

BQ: Bloc Québécois

PQ: Parti Québécois

\section{Political parties in Catalonia and Spain}

CC: Coalición Canaria

CiU: Convergència i Unió

ERC: Esquerra Republicana de Catalunya

ETA: Euskadi Ta Askatasuna

PNV: Partido Nacionalista Vasco

PP: Partido Popular

PSOE: Partido Socialista Obrero Español

\section{International organizations}

ACCT: Agence de coopération culturelle et technique

EU: European Union

GATT: General Agreement on Tariffs and Trade

NAFTA: North American Free Trade Agreement

OIF: Organisation internationale de la Francophonie

UN: United Nations

UNESCO: United Nations Educational, Scientific and Cultural Organization 


\section{Other abbreviations}

AC: autonomous community

AC's: autonomous communities

BNA Act: British North America Act

CARCE: Conferencia para Asuntos Relacionados con las Comunidades Europeas

CARUE: Conferencia para Asuntos Relacionados con la Unión Europea

N-VA: Nieuw-Vlaamse Alliantie (Flemish political party)

REPER: Representación Permanente de España ante la UE 


\section{Research Question and Overview}

The purpose of this research is to develop a model that describes the dynamics of competition between the minority nation and the majority nation for the loyalty of their citizens through the use of public policy. The remainder of this chapter first introduces the academic literature from which the research departs: it covers the existence of minority nationalism, the current situation in Québec-Canada and in Catalonia-Spain, how minority nationalism is constructed, competition between majority and minority nationalisms, as well as some important data on the two cases being studied (Catalonia in Spain and Québec in Canada). An overview of the successive parts of this dissertation closes the present chapter.

\subsection{Literature review}

The existing academic work on minority nationalism has tended to focus on the challenges that such nationalism poses to the central government. It has neglected the competition between minority nationalism and majority nationalism in terms of public policy. Most scholarly work has focused on the reasons for the existence of minority nationalism and on the legitimacy of minority nations' demands (Anderson 2006; Gagnon 2008; Keating 1996, 2004), as well as on the incapacity of most countries to accommodate minority nations and the lacunae of federalism (Nootens, Gagnon, and Lecours 2007).

Majority nationalism refers to the central state's projection of itself (Lecours and Nootens 2007, 21-22). Put simply, majority nationalism is the nation-building emanating 
from the central government, and it reflects the majority culture. It occurs because the central government aims at greater loyalty from its citizens, which in turn increases the legitimacy of the central government. Majority nationalism is somewhat "hidden," that is, it presumes that the state is neutral in relation to the cultural traits of its citizens (Lecours and Nootens 2007, 28). In that sense, it benefits from the "myth of cultural neutrality": it presumes a distinction between the use of culture to consolidate the central state, that is, majority nationalism, and the use of culture by minorities to fight against this order, that is, minority nationalism (Lecours and Nootens 2007, 29). Majority nationalism is "hidden" or hard to discern for two reasons. First, the country allegiance (majority nationalism) is seen as patriotic, while the country contestation (minority nationalism) is perceived as regressive. Second, the country is said to organize egalitarian rapports between citizens; this is convenient for the majority group and groups that are dispersed over the territory (religious minorities, immigrants, etc.), but not for groups that are in the same territory because they feel that the majority nationalism dilutes their own identity (Dieckhoff 2007, 60). According to Alain-G. Gagnon, Ottawa behaves as if it personified alone the Canadian identity and claims to be the only one mandated to do so (2008, 175-176). Now that majority nationalism has been defined, this chapter turns to minority nationalism.

\subsubsection{Existence of minority nationalism}

Minority nationalism deserves interest because it may lead to secession of countries, and because central governments have a duty to take into account national minorities to ensure representation. First, secession is menacing - to various degrees - in some 
countries with minority nations. For example, Québec had two referendums on secession, with almost $50 \%$ of the pro-separation votes in the last one (in 1995). Catalonia's last election in November of 2012 was held with the main political party, the Convergència $i$ Unió (CiU), promising to have a referendum in the next few years. As another example, Belgium's two minorities, Flanders and Wallonia, make for a hardly functioning federation given how long it took to form a government after the 2010 elections (Stroobants 2011). Second, central governments have a duty to strive to represent all of their citizens - if only because it eases the burdens of governance and enhances legitimacy.

Both domestic and global factors foster minority nationalism. The minority nation's sentiment of difference from the majority nation is partly explained by the definition of "minority nations" itself:

"groups that formed functioning societies, with their own institutions, culture, and language, concentrated in a particular territory, prior to being incorporated into a larger state. The incorporation of such national minorities is usually involuntary, as a result of colonization, conquest, or the ceding of territory from one imperial power to another, but may also occur voluntarily, through some treaty or other federative agreement" (Kymlicka 2001b, 72).

Domestic historical or economic circumstances encourage minority nationalism. There is often a story of oppression or subjugation from the majority nation over the minority nation. In the case of Catalonia, the two dictatorships - Primo de Rivera from 1926 to 1931 and Franco from 1939 to 1975 - banned the public use of the Catalan language (Mar-Molinero 2000, 46, 84). In Québec, monolingual and bilingual Francophones had much lower earning opportunities than monolingual Anglophones until the late 1970's (Vaillancourt et al. 2007). 
Minority nationalism is also encouraged by geopolitical circumstances which increase the insecurity of minority nations: a) the boundaries of minority nations do not always match the legal ones (for example, the Catalan Countries encompass more than the autonomous community (AC) labeled "Catalonia" in Spain); b) the separation of powers between different levels of government, as stated in constitutional texts, is often not respected; and c) the political system of federalism does not prevent a threat of secession (Kymlicka 2001b, 93). All these domestic factors lead to the minority nation's request for more recognition and power within the majority nation.

One way through which minority nationalism is expressed is public policies. Linguistic policy offers a prominent illustration. Language is often used by minority nations as a tool to distinguish themselves from their respective majority nations. A minority nation's own language is more than just a tool that members use to communicate with each other: "Seeing language as simply a means of communication is misleading. A language is the expression of a community, carrying its own experience, vision of the world, and system of values, a unique treasure accumulated through ages" (R. Breton 1996, 163). Indeed, many minority nations use their specific language as a means to construct or affirm a boundary between them and their respective majority nations. To minority nations, language is pivotal to the sentiment of identity: "Language is the primary semiotic tool for representing and negotiating social reality, and it is thus at the centre of social and political life" (Bailey 2007, 257). Put differently, language is a core component of the authenticity of a minority nation, linking "the speech community of today and its (real or imaginary) counterparts yesterday and in antiquity" (Fishman 1989, 
274). In sum, minority nations promote linguistic policies that maintain or enhance their vernacular language. Part of the reason they do so is to foster their nationalistic project: "Nationalism intends that language use and language planning both should encourage and facilitate behaviors of broader unity, deeper authenticity, and various modern implementations of sociocultural and political-organizational integration" (Fishman 1989, 299). Foreign policy is also a way of expressing minority nationalism. After all, if a minority nation can be seen in arenas where countries deliberate, it looks like a world player, too. Foreign action gives international recognition to minority nations (Paquin 2008). As for immigration policy, it is pivotal in the survival of minority nations. Minority nations are afraid that most immigrants will integrate into the majority nation, lessening their demographic importance in the long term. Yet, immigration policy, like foreign policy, must be played out diplomatically on the international scene. Minority nations are prudent to appear as respecting individual rights, as being not xenophobic. Québec even limited its collaboration with the Basque Country to toponymy for fear of being associated with violent nationalism (Interview with Guy Dumas 2012).

\subsubsection{Current situation in Québec-Canada and Catalonia- Spain}

The current situation in Catalonia-Spain is one of macro-confrontation. ${ }^{1}$ Catalonia's nationalism has traditionally been autonomist, that is, not formally pro-independence, but rather focused on gaining more power for the $\mathrm{AC}$ while remaining part of Spain. However, in the last few years, Catalonia's nationalism has geared towards independence.

1 Merci infiniment au professeur Guy Laforest d'avoir suggéré cette expression. 
The main reason for this change is the rebuttal in 2010 by the Constitutional Court of the revised Statute of Autonomy of Catalonia. Catalonia's Parliament passed a revised version of its 1979 Statute of Autonomy in 2005. This version was then brought before Spain's Parliament and negotiated between all deputies. The result was a lesser autonomist version which, most notably, did not include the word "nation" anymore and substituted it with the lesser "nationality." In 2006, the Spanish Parliament approved the lesser revised version of the Statute of Autonomy, which was approved the same year by the Catalan population through referendum. The political party PP (Partido Popular, right wing conservative) brought the 2006 Statute before the court, claiming that parts of it were not constitutional. After four years of tergiversations, in 2010, the Constitutional Court judged most of the important advances for Catalonia's autonomy to be not constitutional or gave them an interpretation that did not please the AC. On top of that, the economic crisis in Spain increased the grievances of Catalonia towards the central government. Essentially, Catalonia blames Madrid for unfair redistribution between Spain's AC's (this is discussed in chapter 6).

To put it simply, Catalonia does not feel treated fairly in economic terms by Madrid. And it has a similar feeling, that its identity is not respected by Madrid (Interview with Carles Viver 2012). Catalans are well aware that, at the other end of the European Union (EU), Scotland is pragmatically discussing with England its 2014 referendum (F.-A. D. Michaud, Plante, and Taillon 2012). Catalans wonder, Why not the same recognition from Madrid towards Barcelona? The share of Catalonia's population that is pro-independence is rising. The last Catalan elections on November 25 of 2012 
resulted in a drastic increase in the long-time separatist party Esquerra Republicana de Catalunya's (ERC) votes and strong support for the formerly-autonomist-now-separatist party $\mathrm{CiU} .{ }^{2} \mathrm{The} \mathrm{CiU}$ has promised to hold a referendum on its sovereignty in the next few years. Yet, Madrid, whose president is from the PP, keeps a discourse that AC's spend too much. A civil servant interviewed at the Spanish Embassy in Ottawa said that AC's spend too much because doing so favors their image to the citizens (Interview with Ignacio Sánchez de Lerín García-Ovies 2012). Madrid also portrays itself as rigid towards Catalan nationalism and has made clear that it would not recognize an eventual Catalan referendum on sovereignty ("Umbrage in Catalonia. Even though the spectre of secession is an unwelcome distraction, Spain still needs to change" 2012). Needless to say, the current tension augurs badly for the rapport between Catalonia and Spain in the years to come.

The current situation in Québec-Canada is probably as close to cooperation as possible in an industrialized country with minority nationalism. The two governments have displayed cooperation in their linguistic and foreign policies since the early 2000's and before that for immigration policy. There are sporadic frustrations of both governments towards one another, but the agreements for each policy field studied in this dissertation are not being seriously questioned. Québec has had since the 1990's two main nationalist parties: one in the Québec Parliament and one in Ottawa's Parliament. The last election in Québec, on September 4 of 2012, put the pro-sovereignty party in Québec City, that is, the PQ (Parti Québécois), in power, but with a minority government. The

2 The ERC won 21 seats and the $\mathrm{CiU}, 50$. Together, they have 71 of the 135 seats at the Parliament of Catalonia (Sallon 2012). 
Québec nationalist party in Ottawa, that is, the BQ (Bloc Québécois), lost almost all its seats in the last federal election on May 2 of 2011. More importantly, the discourse is changing within those two main nationalist parties of Québec. A future referendum on sovereignty has been put "on hold" in the program of the PQ of 2011: it will take place "à la suite d'une consultation de la population par référendum tenu au moment jugé approprié par le gouvernement" (Parti Québécois 2011, 3). However, a new political party, Option nationale, has picked up the sovereignty issue, making that its main objective. Québec solidaire, a party created in 2006, also promotes Québec's sovereignty, although that is not its main focus. These two parties obtained fewer than $8 \%$ of the votes in the last election, but their votes are on the rise (Directeur général des élections du Québec 2012). This dissertation would argue that Québécois do not care too much for another referendum. Surveys show that a good proportion of Québécois are prosovereignty (Lessard 2012). Yet, it seems reasonable to assume that they are well aware of the negative consequences of a failed referendum. After the 1980 one, they suffered the imposition of the 1982 Charter of Rights and Freedoms. After the 1995 one, they faced the 2000 Clarity Act. More importantly, one could argue that they do not trust the "classe politique" or politicians as a whole. In the early 2000's, Québécois witnessed the Commission of Inquiry into the Sponsorship Program and Advertising Activities (Gomery Commission) in the federal government. Since around 2010, they have been witnessing journalists' reports of collusion, corruption, and more in both the provincial and municipal governments. Starting in May of 2012, they were learning on a regular basis about the scope of corruption as the Commission d'enquête sur l'octroi et la gestion 
des contrats publics dans l'industrie de la construction (Commission Charbonneau) hears from witnesses. They have stopped believing, at least for some time, that politicians have altruistic reasons for seeking votes. They do not want to say goodbye to sovereignty nor revive the debate - they just want decent use of their income and consumption taxes. In sum, there is currently macro-confrontation between Catalonia and Spain while Québec and Canada face cooperation in the three policy fields studied.

\subsubsection{How minority nationalism is constructed}

Minority nationalism is a phenomenon that seems destined to exist when a group of citizens recognize themselves as similar among each other and different from a larger ensemble in which they find themselves. A well-known description of a "nation" is that of Benedict Anderson. He labels it an "imaginary community." "It is "imagined" because the members of even the smallest nation will never know most of their fellow-members, meet them, or even hear of them, yet in the minds of each lives the image of their communion" (Anderson 2006, 6). And it is "imagined" in two ways: as limited (because even the largest nations recognize "finite" boundaries and do not aim at conquering the whole human race) and as sovereign ("nations dream of being free") (Anderson 2006, 7). As for the term "community," it refers to the idea of an existing comradeship between citizens, even though there is inequality among themselves. Anderson's explanation is in line with the one formulated by Immanuel Wallerstein as to why sub-national movements emerge. In Race, Nation, Class: Ambiguous Identities, Wallerstein claims that all sovereign states (countries) and subgroups (within the former) have an interest in promoting a "national" sentiment in order to lessen the respective threats of internal 
disintegration and external aggression (Wallerstein 1991, 81-82). Moreover, he suggests that the rise of nationalism is explained by the idea that, "For a state not to be a nation is for that state to be outside the game of either resisting or promoting the alteration of its rank [relative to other states]" (Wallerstein 1991, 82). In the same line, Alexander Wendt claims that the state has intrinsic interests that are not socially constructed, that are simply inherent to each of them. In other words, nationalist actions are essential to the preservation of a nation. These interests force the state to act upon them; the state cannot ignore them. Specifically, they are "underlying needs [that] are common to all states and must somehow be addressed if states are to reproduce [develop, maintain] themselves" (Wendt 1999, 235). Moreover, Wendt claims that once states exist, "they acquire interests in reproducing [developing, maintaining] themselves that create resistance to disappearing of their own accord. This creates substantial path-dependency and 'stickiness' in international politics" (Wendt 1999, 238). In that sense, Catalonia and Québec are "states," as are Spain and Canada. The former were (or consider that they were) states-almost-countries before being incorporated into the latter. Catalonia considers that it was an independent entity before the dynasty of the Bourbons in 1715; Québec was independent (although colony of France) until the Treaty of Paris of 1763. Since Catalonia and Québec are states ${ }^{3}$, they are bound to "reproduce" Wendt's interests of the state: 1) physical survival (survival of a state's core territory); 2) autonomy (in the allocation of resources and choice of government); 3) economic well-being; and 4)

3 The word "state" in English cannot be translated to "État" in French. The former refers to a country, while the latter is much broader. For example, a province is an "État," but one could hardly argue that it is a "state." Thus, Québec is undeniably an "État," while the case needs to be made that it is a "state." It is probably a "sub-state" and an "État" at the same time. 
collective self-esteem. The last is relevant for the present paper. It is defined as "a group's need to feel good about itself, for respect or status" (Wendt 1999, 236). It is a basic need for states, just as it is for individuals. And the self-image of a state can be either positive or negative, depending on its relationship with other states, "since it is by taking the perspective of the Other that the Self sees itself" (Wendt 1999, 236). On the one hand, negative images cannot be tolerated for a long time because they lower the "collective self-esteem." If states are confronted with such negative images, "they will compensate by self-assertion and/or devaluation and aggression toward the Other" (Wendt 1999, 237). On the other hand, positive images - or recognition - "[reduce] the need to secure the Self by devaluing of destroying the Other" (Wendt 1999, 237). Put differently, if a state is not recognized by the "other" state, Wendt predicts competition between these two states. However, if there is recognition, one may expect cooperation.

Minority nationalism does not per se entail the goal for independence as a country. If the majority and the minority nations' governments can maintain policies that allow citizens to display a double identity, there is cooperation between the two governments and the minority nation can gain more power in specific policy fields. In Plurinational Democracy, Michael Keating argues that citizens in "stateless nations" (those within United Kingdom, Spain, Canada, and Belgium) display multiple identities - and a multiple nationalist loyalty - but that politicians have not yet understood the current postsovereignty era, hence still think that citizens equate "nation" with "statehood" and seek strict independence when belonging to a stateless nation. To be sure, Keating writes that "many nationality movements do not want a state on traditional lines at all, but seek other 
expressions of self-determination" (Keating 2004, 8). In other words, claims for nationality do not entail claims for statehood; Keating refers to this idea as "postsovereignty era." Keating lists three grounds for nationalistic claims: the first one, which is fading, is that, "the nation is a self-evident sociological category or an immanent community of fate"; the second one refers to the nation as being a historically selfgoverning community; and the third one argues that people of a nation, "see themselves as a nation and wish to determine their future as a collectivity" (Keating 2004, 3). According to Keating, the first two claims "have been used to catch nationalities in a logical trap - they cannot claim self-determination without proving that they are 'different,' yet if they are different they are condemned as ethnic particularists unworthy of self-determination rights" (Keating 2004, 4). In short, if the minority nation can preserve its identity within the majority nation - if it can foster its characteristic public policies - then cooperation probably reigns with the majority nation.

\subsubsection{Competing majority and minority nationalisms}

Minority nationalism occurs partially because of the minority nation's malaise within the majority nation. All majority nations' governments and minority nations' governments have an interest in promoting a "national" sentiment in order to lessen the respective threats of internal disintegration and external aggression (Wallerstein 1991, 81-82). Yet, the strong secessionist movements among Flemish, Scots, and Québécois are living illustrations that the contemporary majority nations' governments have not found ways to accommodate minority nations (Kymlicka 2001b, 91-92). Even though these minority nations are part of federations - which are "successful in the sense of fairly managing 
these conflicts in a peaceful and democratic way, while protecting individual rights and prosperity" (Kymlicka 2001b, 93) - they feel the urge to not only resist the trends set by the majority nation, but also to engage in their own nation-building. They do so in order to sustain their national culture, that is, to promote equality of opportunity and political solidarity (Kymlicka 2001b, 159). Contemporary majority nations' governments have not found ways to accommodate minority nations because the majority nations' governments envision a single-nation (unitarian) state project, while minority nations similarly view themselves as distinct (Gagnon 2008, 21). Majority nations tend to treat all citizens identically, which prevents all national communities within the state of achieving the same level of fulfillment (Gagnon 2008, 15-16). Minority nations do not adhere to their majority nation's unitarian state project, because the national minorities no longer tolerate their "evisceration" by the majority nations' governments, which is done in order to further the idea of the homogeneity of the nation-state: "What such minorities are asking is simple and direct - why should the notion of a homogenous national identity, represented by the language and culture of the dominant ethnie, invariably replace cultural and linguistic identities that differ from it?" (May 2008, 307, emphasis in the original).

One idea used by central governments to curb the minority nationalism problem is multiculturalism. However, this latter fails to fully address the issue of sub-state identity, "which [carries] normative ideas of self-determination and the scope of political authority" (Keating 2004, 17). Put simply, minority nations, such as Québec and Catalonia, seek stronger expressions of self-determination (Keating 2004, 8). And if they 
are not granted more autonomy to develop their identities, Scotland, Catalonia, or Québec might separate from their current majority nations (Gagnon 2011, 4).

The central government's actions partly determine the response of the minority nation and vice versa:

"Nationalist claims must be historically situated. They are made in relation to a particular state form and balance of political and social forces and face a particular array of opportunities and barriers in each case. Contrary to much writing on the subject, nationalist claims are negotiable and have historically been negotiated, managed and compromised. Whether they can be so negotiated depends both on the character of the majority nationalism which they are confronting and on the circumstances of the time" (Keating 1996, 20).

As mentioned in this quote, the study of majority nationalism to counteract minority nationalism is new and not well informed (see also Nootens, Gagnon, and Lecours (2007)). More importantly, the use of public policies in this competition between the minority nation government and the central one - has not been thoroughly researched.

Majority nationalism, or nation-building, may be fostered through: a) education; b) military service, wars, colonialism; c) political practices, traditions, institutions; and d) symbols and myths (Lecours and Nootens 2007, 33-40). Minority nationalism is promoted through public policies as well, through control over education programs, language planning, requirements of immigration, etc. (Kymlicka 2001b, 28, 159).

However, in the academic literature, there is no thorough comparative treatment of public policy of these minority nations. Paquin (2004) compares international relations of Québec and Catalonia. Mar-Molinero (2000) briefly mentions the 1977 Charter of the French Language in Québec when discussing the 1983 Normalization Act in Catalonia. 
Zapata-Barrero (2009b) states that Catalonia is similar in the power it has over immigration to a region of France (that is, very little power) rather than to Québec (which has more power).

\subsubsection{Choice of cases studied}

This dissertation examines two case studies - Catalonia and Québec - to illustrate the variation over the competition between a minority nation's government and that of its majority nation. These two minority nations possess extensive institutional organization to defend their identity (Colomer 2007; Keating 2004, 99). As for language, both Québec and Catalonia have government-created offices that regulate their language, respectively French and Catalan. Québec has the Office québécois de la langue française and Catalonia, the Institut Ramon Llull. Moreover, both Québec and Catalonia affirm their presence internationally. Québec has seven general delegations, five delegations, nine bureaus, four trade branches, and two offices for representation in multilateral affairs (Ministère des Relations internationales du Québec 2012). Catalonia has five delegations, one "house" in Perpignan (France), seventeen centers for the promotion of business, and many more offices that carry different tasks (promotion of the language, tourism, etc.) (Generalitat de Catalunya 2012a). And Canada and Spain have comparable economic standard of living. The GDP per capita of Canada (in purchasing power parity) was $\$ 41,100$ in 2011 and, in Spain, was at $\$ 31,000$ for the same year (CIA - The World Factbook 2011). ${ }^{4}$ On top of that, they are part of a federal (Canada) or quasi-federal

4 The GDP per capita in PPP (the most useful tool for comparison of quality of life) is readily available for countries. Data that are calculated in a comparable manner for Québec and Catalonia have not been found. Québec's GDP per capita in PPP is traditionally lower than the Canadian average and Catalonia's same measurement is higher than the Spanish average. 
(Spain) system (F. Rocher and Lecours 2007, 57). Finally, the comparison of Québec and Catalonia is apt in that they occupy a territory in which a significant proportion of speakers use a language that is unique to their state. 79.6\% of Québécois have French as their mother-tongue as of 2006, while $31.6 \%$ of Catalans have Catalan has their mothertongue as of 2008 (Generalitat de Catalunya 2008c; Secrétariat à la politique linguistique 2009).

It is worth underscoring that Catalonia and Québec both represent a minority nation that is geographically concentrated, thus making their demands for more powers to their minority nation similar. On the other hand, for example, the Roma people, which find themselves across Europe, are not geographically concentrated, have fewer formal institutions to promote their identity, and also have fewer powers over public policy. The same could be said about Jews in Europe, as well as other national minorities which are spread over large territories.

The strength of nationalism is harder to compare between Québec and Catalonia. Nevertheless, there are data on the proportion of the population that identifies as "Only Québécois/Catalan" and as "More Québécois/Catalan than Canadian/Spanish." This "Moreno Question" indicated in 1990-1995 that more than 31\% of Catalans pertained to one of the two above-mentioned categories (Moreno 2001, 115-116). The percentage was more than 51\% in 2007 in Québec (Lachapelle 2007, 603). These data must be used carefully: the methodology was different for the two cases and the years of survey are a decade apart. Yet, a significant part of the population in both minority nations sees itself as different from the rest of the country. In 2004, Keating wrote that whilst Catalan 
nationalism "has historically been more moderate and generally disavows separatism, seeking to project Catalonia as a nation within a reconfigured state" $(2004$, vi), the French Canadian identity has "evolved into a territorial-linguistic identity based on the province of Quebec and a search for recognition as a distinct nation" (2004, vii). This might not be accurate anymore. Since the revision of the Statute of Autonomy of Catalonia in 2006, there has been without a doubt a serious rise of separatism in Catalonia (Interview with Carles Viver 2012; Interview with Xavier Bernadí Gil 2012). The frustration of Catalonia towards Spain is widely palpable, as evidenced by the joint editorial of twelve newspapers on November 26 of 2009 titled "The dignity of Catalonia" (translated from Castilian to French in Gagnon 2011, 187-190; "La dignidad de Catalunya" 2009). In Québec, many would agree that separatism is not on the rise at the moment (Radio-Canada 2011). In sum, Catalonia and Québec share enough in common to be comparable, yet their nationalistic dynamics are sufficiently different that there is much to learn from their comparison.

\subsection{Layout of the dissertation}

The rest of this dissertation is composed of five chapters. Chapter 2 discusses the literature on public policy and minority nationalism. The academic literature does not touch on the competition that takes place between the minority nation's and the majority nation's governments via the use of public policy. The chapter then presents how this dissertation fills this gap with a model. This model divides actions that form public policies in three categories: cooperative, neutral, and confrontational. Two main conclusions are derived. First, cooperation - in the form of incremental actions by the 
minority nation's government - yields higher returns in the long run for both governments, thus they will eventually go back to this type of action. Second, confrontation does happen when a government thinks that it has an advantage or when it wants to advance a public policy in a significant manner.

Chapters 3, 4, and 5 constitute the empirical part of the dissertation: each chapter focuses on one policy field and studies the policy actions that compose the competition between Québec-Canada and Catalonia-Spain from the 1960's or 1970's up to now. Chapter 3, on linguistic policy, shows the continuous competition that took place between Québec and Canada from the 1960's up to the 1990's. One government would enact a policy action and the other government would reply with another policy action. The most emblematic case of competition between minority and majority nations' governments through public policy is Québec's 1977 Charter of the French Language which was followed by Canada's 1982 Charter of Rights and Freedoms. While the former aimed at obligating all children from English Canada to attend French public schools in Québec unless Québec had an agreement with their province of origin, the latter stipulated that children whose parents were taught in English anywhere in Canada could attend English public schools in Québec. This is clear competition using public policy. Québec used confrontation in 1977 because it sought to advance its linguistic policy with a big step as it did not think that the federal government could protect the French language in Québec and decided to take charge; Ottawa replied with confrontation. Since the 1990 's, after a series of court rulings over linguistic legislation, cooperation has resumed between Québec and Ottawa over linguistic policy. Canada's Commissioner of Official Languages 
said, in an interview, that both governments now treat linguistic policy as their own domain, without discussing it with one another (Interview with Graham Fraser 2012). In Catalonia-Spain, linguistic policy was managed in a cooperative manner until Catalonia decided to take a big step to advance its linguistic policy, in the late 1990's. After Franco's dictatorship (during which Catalan was essentially forbidden), encouraging the use of Catalan was seen as a way of moving towards democracy, away from Franco. However, as Catalan regained vigor, being used and learned more, Catalonia decided to make it the AC's "own language." This meant promoting its use in education and in the public sphere. In 1992, the "Decree that establishes the structure of the mandatory education in Catalonia" made Catalan the main language of education in Catalonia. There was an outcry of those who wanted their children taught in Castilian in Catalonia, but there was not explicit confrontation between Madrid and Barcelona. In 2006, however, Catalonia enacted a revised version of its Statute of Autonomy and this commenced the current macro-confrontation that is occurring in many policy fields between Barcelona and Madrid. In 2010, the Constitutional Court of Spain declared many parts of the new Statute not constitutional, weakening the advancement of linguistic policy for which Barcelona was hoping. For example, the new Statute planned for the right to communicate in Catalan with businesses in Catalonia and the Constitutional Court judged this unconstitutional.

Chapter 4, on foreign policy, shows confrontation between Québec and Ottawa from the 1960 's to the late 1990 's. Québec wanted to advance its foreign policy in a significant way in the 1960 's, putting into place the Gérin-Lajoie doctrine which 
stipulated that provincial jurisdictions were to be managed by Québec on the international scene. Ottawa disagreed, claiming that international relations were its jurisdiction according to paragraph 132 of the British North America Act (BNA Act). On a few occasions, France helped Québec gain presence in international meetings in the 1970's. Eventually, Ottawa and Québec resumed cooperation beginning in the early 2000's. After Franco's death, in 1975, Catalonia willingly accepted that Spain had all powers related to international relations as stipulated in the 1978 Constitution. However, as Spain increased economic exchanges, with Catalonia at the forefront of AC's, this became less of an acceptable situation for Barcelona. Eventually, in 1994, the Constitutional Court judged that AC's, including Catalonia, could carry "external relations" but not "international relations." In essence, AC's were allowed to have lobbying offices in Brussels. Unlike Québec-Canada, where France was an important player in advancing Québec's foreign policy, the adhesion of Spain to the EU did not lead to more power in foreign policy for Catalonia. The 2006 revised Statute of Autonomy of Catalonia planned for a seat at UNESCO (United Nations Educational, Scientific and Cultural Organization) for Catalonia, a bilateral Catalonia-Spain commission on international affairs, and a right for Catalonia to ask Madrid to sign international treaties related to its jurisdictions. These were deemed unconstitutional by the Constitutional Court in 2010. The confrontation in foreign policy between Barcelona and Madrid that commenced in 2006 is still going on as of Summer 2013.

Chapter 5, on immigration policy, shows continuous cooperation between Québec and Ottawa from the 1960's up to the present. Using incremental changes in its 
immigration policy, Québec gained more and more power. As of Summer 2013, Québec appears totally satisfied with its relationship with Ottawa when it comes to immigration policy. ${ }^{5}$ On the contrary, there is confrontation between Barcelona and Madrid over immigration policy. In 1978, when Spain enacted its Constitution, there was net emigration in the country. Starting in the 1990's, however, Spain and especially rich Catalonia were net immigration territories. Catalonia sought to gain more power over this policy. Beginning in 2000, it took measures related to its own jurisdictions, education and social services (for immigrants), and held wide consultations on immigration in Catalonia. Madrid did not try to stop Catalonia. However, when the judgment of the revised Statute of Autonomy came in 2010, many parts of Catalonia's immigration policy were deemed unconstitutional. Moreover, the central government has drastically reduced integration funding (done by AC's) and Catalonia finds itself with no money to take care of immigrants as of Fall 2012 (Interview with Xavier Bosch 2012).

Chapter 6 concludes the dissertation. It summarizes the dissertation and discusses the model in light of the empirical chapters. One of the most important conclusions is that incremental changes for a minority nation's government are more likely to yield larger powers and drastic changes in the long term. With incremental changes, the majority nation's government has small changes to do on its end. Moreover, incremental changes are less likely to appear as favors to other provinces or AC's. Another important

5 I emailed and phoned the ministère de l'Immigration et des Communautés culturelles du Québec for three months (February - May 2012), after which I was granted a 30-minute interview (the minimum it could last according to my Ethics Clearance) with two civil servants who handed me a three-page document in answer to my previously sent questionnaire. These three pages contained only basic information on immigration that could be easily found on the ministry website. During the interview, the two civil servants replied to every question by reading their three pages of answers. Regrettably, contacts with this ministry did not provide useful information for this dissertation. I contacted the ministère again in October 2012, after the election of the PQ. My request for an interview was refused. 
conclusion is that confrontation between a minority nation's and a majority nation's governments occurs when a government thinks that it has an advantage or when it wants to advance a public policy in a significant manner; macro-confrontation, that is, confrontation across policy fields, can ensue. 


\section{Framework and Methodology}

This chapter consists of the full presentation of the framework that will be used to describe the competition occurring between the minority nation's government and the (majority nation) central government through public policies. Following the presentation of the framework is a description of the methodology of the research.

The framework links: a) the competition that exists between the central government and the minority nation's government; with b) the public policies that both employ. The competition is played out at the level of public policies. The core of the model is the incrementalism of the requests for more powers by the minority nation's government to the majority nation's government. To make this model tangible, this dissertation uses a historical description of the three fields of policy selected, beginning in the 1970 's. Each action composing a public policy since the 1970's is labeled as "cooperative," "neutral," or "confrontational." These labels demonstrate that a series of cooperative and neutral actions, which are generally incremental, on the part of the minority nation's government favor a similar, that is, a cooperative or neutral response from the majority nation's government. Conversely, confrontational actions on the part of the minority nation's government seem to generate confrontational responses on the part of the majority nation's government. When confrontational actions do occur, they sometimes successfully modify the policy of both governments; at other times, they commence a series of confrontational actions between the two governments. Eventually, both governments return to cooperative or neutral actions. Otherwise said, if the minority 
nation wants more power, in the long term, cooperative and neutral actions are more likely to yield results.

Three situations are likely to see the use of confrontation: when a government sees an advantage, a momentum; when a minority nation's government thinks that it does not have a choice but to use confrontation in order to advance a policy; and in episodes of macro-confrontation, that is, when confrontation remains unsolved.

\subsection{Political competition in public policy}

This section commences by a description of the academic literature relevant to the thesis, that is, literature on competition between the minority nation and the majority nation. After highlighting the gap in the literature that this dissertation wishes to fill, it continues with a model of competition in public policy that will serve as a framework for the analysis of the cases studied.

\subsubsection{Evolution of minority nationalism}

How does minority nationalism evolve? What is interesting about minority nationalism is its correlation with important changes in history. Otherwise said, nationalism does not advance or change during status quo; it changes as a reaction to larger changes that affect the world. This dissertation argues that four stages can be identified throughout the history of nationalism. The first stage prepared the way for the next ones by allowing future nationalism to center around language. The invention of the printing press in the $15^{\text {th }}$ century and the Protestant Reformation in the $16^{\text {th }}$ century are key elements of this first stage. In order to make monetary profit, printers could not publish books only in 
Latin, a market that was fast saturated. Thus, they published in vernacular languages. However, publishing in all vernaculars would have meant no profit. They could publish in a few vernaculars, knowing that surrounding ones would still understand (and they would sell books). For example, in a region where three vernaculars were spoken, publishing in only one of these meant that people speaking any of the three vernaculars could understand enough to buy the book. Some vernaculars became more prominent, because they were used in published works. Moreover, the Reformation encouraged the publication of the Bible in vernacular languages. Anderson reports that: "Between 1522 and 1546, a total of 430 editions (whole or partial) of his [Martin Luther's] Biblical translations appeared" $(2006,39)$. The replacement of Latin by vernacular languages in Europe was central for the next stage of nationalism.

The second stage occurred when the concept of "nation" became widely accepted in the $18^{\text {th }}$ century (Hastings 1997, 119; Smith 1993, 85). Anne-Marie Thiesse (2001) demonstrates, for almost every European country, the construction of the nation in the $18^{\text {th }}$ century:

"Les nations modernes ont été construites autrement que ne le racontent leurs histoires officielles. Leurs origines ne se perdent pas dans la nuit des temps, dans ces âges obscurs et héroïques que décrivent les premiers chapitres des histoires nationales. [...] Les premiers exemples ne sont pas antérieurs au XVIII ${ }^{\mathrm{e}}$ siècle : pas de nation au sens moderne, c'est-à-dire politique, avant cette date" (Thiesse 2001, 11).

With incredible consistency across European nation-states, Thiesse (2001) shows that a book of poems glorifying the countryside of the nation is "discovered," then painters concentrate on elements that differentiate their nation from others, after which national costumes and dishes are pinpointed, and so on. Essentially, "nations" were man-made 
throughout Europe in the $18^{\text {th }}$ century, all following the same toolkit. Why did the "nation" become prevalent in the late $18^{\text {th }}$ century? Because of the economic change (Anderson 2006; Hastings 1997; Thiesse 2001), along came increases in the expenses of the state and the size of its bureaucracy (Anderson 2006, 76-78; Breuilly 2005, 37-38). The state communicated with its dwellers using one vernacular over others and promoting itself, the "nation."

The third stage corresponds to the end of the Second World War and the economic affluence that ensued in the 1960's and 1970's when minority nationalism became prevalent in the world. This is when Basques, Catalans, Irish, Scots, Flemish, and Québécois saw the development of strong nationalist movements. (In the cases of the Basque Country and Catalonia, nationalism could hardly be displayed before the end of Franco's dictatorship in 1975.) Keating claims that these nationalisms are directly related to changes in the power of the state: "For the most part, the peripheral nationalisms of developed western societies represent attempts to come to terms with the changing constellation of power and to reconstitute politics on a territorial basis which is legitimated historically but which can be used to confront contemporary political and economic realities" (Keating 1996, 53). To be sure, Keating links the rise of nationalism since the mid-1900's to globalization and writes that:

"The state's powers and competences are being eroded in three dimensions. From above, the state's power is eroded by global economic change and continental integration. From below, it is challenged by a re-assertion of substate identities and the emergence of policy issues with which it is illequipped to deal. Laterally, it is being eroded by its declining ability to mobilize collective action and consciousness" (Keating 1996, 24).

Dieckhoff (2000) comports with the idea that the minority nationalisms that flourished in 
the 1960's and the 1970's did so as humans were becoming more similar that they ever were before (via communication, traveling, mass media, etc., discussed later). He suggests two main explanations for the rise of minority nationalism. He claims that, as Québécois, Catalans, and other minority nationalists perceive that people are increasingly homogenous, small differences become more important. Or perhaps minority nationalists are afraid of the world becoming "un magma social informe" (Dieckhoff 2000, 30). In either case, the fact that people are more and more similar seems to be the cause of the rise of minority nationalism in the 1960's and 1970's.

The fourth stage of change in nationalism might be taking place now. One could argue that, in the midst of the aftereffects of the current European financial crisis, impacted nationalist movements will be increasingly directed towards independence. As of Summer 2013, the three most prevalent nationalist movements of Europe, i.e. Catalonia, Scotland, and Flanders, all plan - to various degrees of seriousness - to make a step further in nationalism towards "independence." Catalonia's Parliament voted a resolution stipulating its right to hold a referendum on auto-determination in September of 2012 (Generalitat de Catalunya 2012b, sessió núm. 39.1 2012). Scotland is planning a referendum in 2014 (Le Monde.fr and AFP 2012). Flanders' rising political party N-VA (Nieuw-Vlaamse Alliantie) envisions the "dissolution" of Belgium in the near future (Franco 2012). These referendums and dissolution have yet to be concretized, but they are, indeed, new in the sense that they were not such significant parts of the political agenda a few years ago. 


\subsubsection{Management of minority nationalism by the majority nation's government}

In its most basic form, there are two types of actions that a central government can take to deal with minority nationalism. First, it can try to "crush" it, that is, try to make it disappear. To do so, the central government can use military action against minority nationalism. It can also employ financial tools, or financial menace. For example, a central government could openly decide to put an embargo on the territory where minority nationalism is present. It could outwardly forbid the use of the minority nation's language. Or it could be more subtle and use assimilationist measures, such as increasing immigration where there is minority nationalism or promoting majority nationalism's traits as offering more potential, more guarantee of a successful life. It could even ignore the minority nationalism: refusing to deal with it might eventually lead to its end. The central government could also decide to impose its rules on the minority nationalism. For example, Ottawa's Clarity Act of 2000 stipulates that, after a referendum on sovereignty in Québec, the Parliament of Ottawa would decide by itself whether the question was clear and the polls high enough to start negotiating the separation of Québec (F.-A. D. Michaud, Plante, and Taillon 2012). On the one hand, this strategy may indeed destroy the minority nationalism due to, on a full spectrum, either deaths of the minority nationalists or mere assimilation. On the other hand, this strategy may strengthen the minority nationalism; again on a wide spectrum, the minority might get international support or protection, or threat of disappearance may act as a catalyst for the minority nation to create its own institutions and become more perennial than before. 
Second, the central state can give the minority nationalism what it seeks. It can push decentralization, giving more powers and full financial autonomy to the minority nationalism. A potent illustration of this strategy is Belgium, where the federal government only has responsibility in army, central banking, and a limited one in international actions - the remaining competences belong to communities and regions of Belgium. On the one hand, this strategy satisfies the minority nationalism, giving it was it asks for, that is, more autonomy. On the other hand, once the minority nation has so much autonomy, there is a small step remaining before becoming a full state itself and independence would require "little" work.

This is what Kymlicka (2001b) labels the "paradox of multination federalism": it seems that for the central state, there is no strategy that allows for minority nationalism to be managed. This paradox might explain why states seem to have such trouble dealing with their minority nations. Kymlicka (2001b) examines the situation of minority groups in Western democracies. He concludes from studying the strong secessionist movements of the Flemish, Scots and Québécois, that contemporary states have not yet found ways to accommodate minority nations (Kymlicka 2001b, 91-92). Federalism is somewhat successful in accommodating minority nations, that is, "successful in the sense of fairly managing these conflicts in a peaceful and democratic way, while protecting individual rights and prosperity" (Kymlicka 2001b, 93). But it is no panacea, namely because the borders of sub-nations do not always match the legal ones ${ }^{6}$, because the separation of powers between different levels of government is not respected, and because federalism does not prevent a threat of secession. On the bright side, federalism does create a loose

6 For example, the territory where Catalan is spoken is larger than the Spanish AC called Catalonia. 
sense of "togetherness," even if it involves questioning the federation (Kymlicka 2001b, 93-94). Indeed, "the paradox of multination federalism [is that] while it provides national minorities with a workable alternative to secession, it also helps to make secession a more realistic alternative to federalism" (Kymlicka 2001b, 118).

All central governments display some majority nationalism, and if the minority nationalists do not also promote their nation, then majority nationalism will supersede the minority nationalism, eventually leading to the disappearance of the latter. Kymlicka illustrates this phenomenon with findings on the specific case of Québec. He suggests that Québec is a model of a minority nation that has resisted nation-building from the majority nation - through nation-building itself (Kymlicka 2001b, 156-158). According to Kymlicka:

“it is not enough for a minority to simply resist the majority's efforts at diffusing a single common language. The minority must also engage in its own competing form of state-sponsored nation-building. Nationalists in Quebec or Puerto Rico realize that to sustain their national culture, they too must seek to diffuse a common culture and language throughout their society so as to promote equality of opportunity and political solidarity. And they must use the same tools that the majority nation uses in its program of nationbuilding-i.e. standardized public education, official languages, including language requirements for citizenship and government employment, etc." (Kymlicka 2001b, 159).

Of these two strategies that the central government can use to deal with minority nationalism, Alain-G. Gagnon (2008) favors the second one. He studies how in federal states the pursuit of identical rights for everyone - a unity vision toward which federal states tend - can be accommodated with the ideal for people in minority states who seek a community identity. Gagnon writes that federal states are incapable of making everyone adhere to a national (unitarian) state project $(2008,21)$. He recommends that federal 
states move from a "territorial federalism" to a "multinational federalism." While the former treats all citizens identically, the latter offers the same possibilities of fulfillment to all national communities within the state (Gagnon 2008, 15-16). He claims that this transition is the freedom condition par excellence for minority nations (Gagnon 2008, 17). According to Gagnon, four key elements explain federalism and the way it deals with internal conflicts: 1) non-superposition of powers between government levels in order to respect their shared sovereignty; 2) autonomy of political entities while encouraging collaboration between them; 3) hence confidence ("lien de confiance"); and 4) its corollary, federal loyalty and solidarity (2008, 18-19). Gagnon argues that nonrecognition of a nation leads to a feeling of oppression, and that the recognition of the institutions of a nation is crucial $(2008,30)$.

Kymlicka (2001a) also shows an interest for rights and individual fulfillment within minority nations. He claims that countries that protect only individual rights and not minority nations' rights do not treat all individuals equally. Central states promote one culture over another, that is, the majority nation's culture: “Inévitablement, l'État fait la promotion de certaines identités culturelles qui, par là même, portent préjudice aux autres. Une fois que l'on accepte cela, il reste à repenser la légitimité des revendications formulées par les minorités" (2001a, 158). Kymlicka argues that national minorities do not have the economic nor demographic powers that are necessary to defend their cultural identities when politics required for their survival are being discussed (2001a, 160). The author calls the defense of minority nations' rights a "liberal conception of the rights of minorities" (“conception libérale des droits des minorités”) (2001a, 113). According to 
him, so-called liberals oppose the recognition of national rights and favor individual rights since the end of the Second World War due to three events: 1) Nazis used the feeble protection of Germans (a national minority) in Poland and the Czech Republic to invade these countries; 2) the American movement against racial segregation (i.e., the Brown v. Board of Education court case) was centered on individual rights; and 3) some immigrant groups experienced an "ethnic revival" in the U.S.A. after the Second World War and expressed an anti-conformist (i.e., anti-integration) attitude towards the country (2001a, 87-88). These events encouraged the so-called liberals to favor individual rights over national minorities' rights. Kymlicka (2001a) deems it unfair to national minorities' individuals.

Stephen May is in favor of the same strategy of the central government towards minority nations as Alain-G. Gagnon and Kymlicka. May "attempts the unenviable and increasingly unfashionable task of defending the ongoing relevance and importance of minority languages in the modern world" $(2008,1)$. May argues that the national minorities no longer tolerate their "evisceration" by the central government, which is done in order to further the idea of the homogeneity of the nation-state, itself based on the basis of political cohesion and "civism." According to May, the problem comes from the majority nation's government: "It is not the cultural, linguistic and political expression or mobilisation of (minority) ethnicities and nationalisms which are the cause of so much contemporary mayhem in the modern world, but their disavowal" (May 2008, 308, emphasis in the original). Hence, May suggests a reconfiguration of the nation-state "in order to accommodate greater cultural and linguistic diversity" (May 2008, 311). 
In sum, minority nationalism poses a menace to the majority nation's central government. Since the 1960's and 1970's, minority nations (at least in industrialized Western countries) have wanted more autonomy, more power - not necessarily independence - and they use the same tools as the majority nation to promote themselves, most of which are public policies. This threat for the central government can be managed in two main ways: the central government can try to annihilate minority nationalism or it can try to appease it by granting more powers to the minority nation. Gagnon (2008), Kymlicka (2001a, 2001b), and May (2008) favor the latter.

The academic literature discusses how minority nationalism has evolved over the years. This dissertation has argued that minority nationalism changes when larger changes take place in the world and has dissected the history of minority nationalism in four stages. Central governments faced with minority nationalism can use two broad options to manage it. They may try to eliminate it or they may try to manage it. The former might strengthen minority nationalism while the latter risks fostering independence in the long run. Prominent scholars of minority nationalism unambiguously favor the latter because it allows minority nationalists more equality and higher fulfillment. The academic literature does mention public policies such as education, language, and literature as instruments of both minority and majority nationalisms. But it does not discuss their use by minority and majority nations' governments in the competition that they have over the loyalty of their citizens. How do they use these policies? What are the dynamics? This is the academic gap that this dissertation hopes to fill. 


\subsection{A model of political competition in public policy}

In order to describe the competition between minority and majority nations' governments via public policies, a model has been developed.

\subsubsection{Definition of "public policy"}

In line with Leslie A. Pal, this dissertation defines "public policy" as "a course of action or inaction chosen by public authorities to address a given problem or a set of problems" $(2009,2)$. Pal asserts that the problem definition, its goals, and its instruments constitute a "policy" (2009, chap. 1). Two elements related to the definition are worth underlining in the context of minority nations. First, policies are often enacted without a thoroughly rational process: "we presume that our governments are doing more than rambling, that they have a plan $[\ldots]$ This presumption will often be proven wrong - government actions may be the result of accident, instinct, or habit, rather than policy" (Pal 2009, 14). Policies which are changed during periods of high tension between a minority nation's and a majority nation's governments are susceptible of non-rational decisions because they are taken at times rife with conflict. The argument of this dissertation is based on the premise that people, including those who compose the government, feel loyalty to one or both governments; thus, the fact that people's conception is shaken during episodes of macro-confrontation is not conducive to rational decisions. Second, policies are in large part symbolic. Governments sometimes do not use policies to fix a problem: "Politicians may decide that they want to 'send a message' rather than solve a specific problem" (Pal $2009,8)$. Arguably, this is very much the case in countries with a minority nation. Writing 
specifically about minority nations, Malloy argues that a public policy in a specific field represents the position of the government that enacts it $(2005,35)$. Minority nations' governments seek to preserve the peculiar identity of the minority nation they represent by enacting policies favorable to the development of these peculiar characteristics. Majority nations' governments will also seek to promote a national identity that encompasses the minority nation's inhabitants. Hence, public policies that are deemed representative of identity are, at least in part, symbolic.

For the purposes of this dissertation, a public policy is made of a series of actions taken by a government to address an issue or a set of issues, and symbolizes the position of the government behind it. This implies that a policy in a specific field maintains the same label over time. For example, the immigration policy of Catalonia has not changed over the years. The actions that constitute it, however, can change. The objectives of the policy are malleable as time goes by, as elected government representatives are replaced, and as values within the population evolve. The policy can more or less align with that of the corresponding minority or majority nation. In other words, there is only one, as an illustration, foreign policy in Spain for the whole period covered in this dissertation. Sometimes, its actions are in confrontation with the foreign policy of Catalonia and, at other times, Spain's foreign policy's actions are in cooperation with Catalonia's foreign policy.

\subsubsection{Governments and citizens' loyalty}

The minority nation's citizens seek to maintain or develop their own identity. Thus, they will grant their loyalty to a specific government based on this prominent need. Citizens 
can assess governments mainly through their actions and these governments' actions are what compose public policies. As for governments, they have an incentive to replicate the identity of their citizens through public policies because the loyalty that they hence obtain is convenient for them in practical terms.

What is loyalty? Identity and loyalty have a long pedigree in the study of democratic systems (Lijphart 1977). In this dissertation, loyalty refers to the nationality which citizens admit towards one government or two governments. In other words, loyalty consists of the self-description of oneself: one either adheres to being Catalan or Spaniard or both. Maalouf's Les identités meurtrières discusses the complex issues that surround one's identity. Identity is generally presented in opposition to another one (Maalouf 1998, 21). For example, if a group of people's religion is threatened, this group will define its identity in opposition to another group's religion. This definition of identity by opposition to another group works not only with religion, but also with language. Language is very likely to determine one's identity because it is the medium through which one envisions the world (Maalouf 1998, 152-160). Maalouf writes that "De toutes les appartenances que nous nous reconnaissons, [la langue] est presque toujours l'une des plus déterminantes" of the elements that make one's identity $(1998,152)$. It is a tautology to assert that loyalty is difficult to measure. Yet, quantitatively, loyalty can been approached by the Moreno Question (discussed earlier) that asks one's feeling of national belonging. Occasional surveys as to whether people would vote for independence also bring information as to whether citizens feel more loyal to one government or another or both. In sum, citizens are likely to give their loyalty to the government or the two 
governments that they sense represent(s) or defend(s) best their identity. Some elements are core components of one's identity: this dissertation focuses on language (and immigration, by extension) as well as international image.

Loyalty is crucial to determine a government's potential room to maneuver. The more citizens' loyalty a government possesses, the more easily it can enact the specific public policies that it wants to implement because citizens assert that the government does match their needs, that it is legitimate. In this dissertation, governments are seen as composed of individuals who stay for a certain time in the government and care deeply about one issue or a few ones (but not all issues that a government does face). The individuals who make a government seek to advance this or these specific issue(s) that are so important to them. In order to further these few issues, they need citizens' support, which can be gained for a short or for a long term. To gain support for a short time, a government can lower taxation or build an important building for a sports team, for example. This momentary support might not be enough to allow a government to implement a significant policy, but it might be enough to be reelected and gain prestige. To gain support in the long run, however, a government has to obtain citizens' loyalty. This loyalty allows a government to implement more significant public policies that have the power of changing the nation. The citizens' loyalty is a capital good that can be depreciated or augmented. In order to procure it, both the minority nation's government and the majority nation's government seek to represent as many components as possible of the identity of their respective citizens through government action, that is, public policies. $^{7}$

7 It is outside the scope of this project to discuss the construction of the citizens' identity by governments. 
Most democratic governments seek the maximization of their citizens' loyalty. Citizens are loyal to their government (be it the minority nation's one or the majority nation's, or both) because they believe that it is better for them or that it will become better for them than the other option available. Hirschman claims that "nationalist" loyalty can be envisioned the same way as political convictions, church denominations or tribes (Hirschman 1970, 33). ${ }^{8}$ To put it simply, nationalist loyalty is a profound sentiment which is difficult to modify. What people ultimately seek in a national identity is a arduous question. The main academic literature on the topic converges towards some necessary feeling of group belonging (Smith 1993, 74). This dissertation hastens to dissent that this group-belonging explains nationalism. If citizens merely wanted to feel like they belonged to a group, national minorities' citizens could simply transfer this belonging need from their state to a transnational community; for example, if all that Catalans needed was a sense of group-belonging, they could adhere to the international pro-ecology community or to the fair trade movement. Moreover, the rise of minority nationalism in the 1960 's arguably corresponds with the progression of globalization, hence the more transnational movements available for national minorities from which to choose. But national minorities' citizens are not satisfied with the perspective of simply belonging to a transnational issue group.

Akerlof and Kranton (2005) theorize that citizens do not only have pecuniary interests. In fact, their utility function (or well-being) is shaped by what they envision as an ideal (Akerlof and Kranton 2005). This may include religious values, cultural values,

8 In that sense, "being loyal" means that, even after betrayal, people remain loyal to their government. For example, even though the Québec government forced municipal fusions under Québec's Premier Lucien Bouchard, the affected (yet unhappy) citizens still define themselves as more Québécois than Canadian. 
or others. Put differently, the economic wealth is not all that matters. For example, having one's descendants be fulfilled because they speak the language of their parents might count, too. This dissertation suggests that national minorities demand recognition because they wish to raise their descendants in their language and identity. Why? Because they believe that these will give their descendants the most fulfillment, the greatest happiness. An alternative explanation would be that national minorities' parents are self-interested and seek to maintain strong ties with their children, grandchildren, and greatgrandchildren, thus the need for these latter to speak the same mother-tongue and to share similar values and identity with their ancestors. As evidence, national minorities are not satisfied with "linguistic security" - the linguistic notion of being able to carry one's daily obligations in one's language. Rather, national minorities seek "linguistic survival"; current citizens of national minorities want their language and identity to be maintained or developed throughout time. National minorities are not satisfied with mere language laws that grant them the right to pursue their lives in their language; they want power over laws that affect their identity in order to secure power to influence, to orient their identity. What is more, they want to possess their own institutions to protect and develop the key elements of their identity. The government that offers the strongest potential for perpetuating one's language and identity will receive one's loyalty. Hence, citizens will be loyal to the government that offers the highest potential of long-term maintainability of their language and identity.

To summarize, governments seek their citizens' loyalty; it is useful for enacting not so popular policies or ones about which a government really cares. In return, citizens 
may assess their governments (and whether they want to give them their loyalty) mainly thanks to their policy actions. Thus, public policies are at the center of the rapport between citizens and governments. Citizens in national minorities do not want to be granted the right to speak their language at home. Rather, they want to be sure that their descendants will be geared by public policies towards speaking it, too. This way, their descendants will have the highest potential of fulfillment (if the parents are altruistic) or the greatest chance of speaking their parents' language (if their parents are selfinterested).

Identity may be envisioned as a bundle of many characteristics. Thus, identity, like any other good, should not be thought of as a single object, but rather as a set of joined mini-goods. In a famous example, Kelvin Lancaster lists a car's characteristics (accommodation, ride qualities, handling and steering, engine, brakes, frequency of repair record, and retail price) and demonstrates that some of these characteristics are more important for a given individual than are other characteristics (Lancaster 1971, 170). In the case of the cars analyzed by Lancaster, ride qualities and brakes were, surprisingly, the least important characteristics for a majority of respondents $(1971,174)$. The lesson from this research is that what matters to an individual or to a government may appear frivolous or irrelevant to a peer. Nevertheless, one's assessment of the value of specific characteristics is as relevant as another one's assessment of the same characteristics. Identity, in that sense, is conceived of as a mix of various elements. In the case of national minorities (Québec, Catalonia), language can be said to be a component of identity. Language and international presence might be viewed as primordial for minority 
nationalists, while security and transportation carry more importance for the majority nation's government.

Many sub-states perceive a difference between their collective identity and that of the majority nation. For example, the citizens of Andalusia call themselves Andalusian Spaniards, meaning that they self-identify both with Spain and with Andalusia. That said, this difference between the country-as-a-whole's identity and the sub-state's identity is more acute in minority nations, notably where the language spoken is specific, as is the case in Catalonia and in Québec. In other words, the citizens of a minority nation as Andalusia may display the identity $\mathrm{I}_{\mathrm{A}}=\left\{\mathrm{a}_{1}, \mathrm{a}_{2}, \mathrm{~s}_{1}, \mathrm{~s}_{2}\right\}$, where $\mathrm{a}_{\mathrm{i}}$ are components proper to the identity of Andalusians, and $s_{i}$ are components of the identity of all Spaniards. By contrast, the identity of Catalans would look like $I_{C}=\left\{c_{1}, c_{2}, c_{3}, c_{4}, s_{1}, s_{2}\right\}$. Hence, the proper identity of Catalans is larger (or more prominent) than the Andalusian one: $\left\{c_{1}, c_{2}\right.$, $\left.\mathrm{c}_{3}, \mathrm{c}_{4}\right\}>\left\{\mathrm{a}_{1}, \mathrm{a}_{2}\right\}$

By their own nature, citizens identify with a government if it represents what they believe to be their identity. The central government may display its representation of the minority nation through public policies that match the minority nation's citizens' reality, but it is limited because it must represent the citizens of the entire country. Madrid could try to enact policies in $\mathrm{c}_{3}$ or $\mathrm{c}_{4}$, but it would have to do it to for other regions at the same time, such as Andalusia, where there exists no equivalent of $c_{3}$ nor $c_{4}$. Thus, if Madrid sought to interact with a minority nation's identity, it would be restricted to components 
that are prevalent in all of its minority nations, such as $a_{1}, a_{2}$ and $c_{1}, c_{2}-$ and then Madrid could not possibly match these components, because $a_{1} \neq c_{1}$ and $a_{2} \neq c_{2}$ by the definition of a minority nation. The minority nation's government is advantaged in that it can show that it represents this proper identity of the citizens via the enactment of policies that address specifically the minority nation's identity, particularly linguistic policy. In other words, it is easy for Barcelona to address public policy in the specific fields $c_{1}, c_{2}, c_{3}$, and $\mathrm{c}_{4}$. Even more, this government can invest the public policy of $\mathrm{s}_{1}$ for the territory of Catalonia alone.

The characteristics specific to a minority nation's identity and different from the majority nation's identity are probably fewer than in the past in Québec and Catalonia (Dieckhoff 2000). Humans (at least in the industrialized world) are more and more subject to the same cultural media; travel more; and communicate more with people from outside their own region. Yet, as globalization has been impacting Québécois since around the 1960's and Catalans since around the late 1970's, minority nationalism has grown, as discussed earlier. What really matters is that citizens of the minority nation think of themselves as different from the majority nation and that this is encouraged by the minority nation. For example, Béland and Lecours show for Flanders and Québec that both minority nations have developed a different social policy than their majority nation and that both frame it as part of their minority nationalism: "les politiques sociales formulées par des gouvernements régionaux [la Flandre et le Québec] peuvent participer à la formation d'une identité distincte de celle associée à l'État central” (2004, 320). To 
put it simply, Flanders and Québec both foster and promote their differences from the majority nation through social policy. This dissertation does not dare to list which characteristics Québécois and Catalans list to differentiate themselves from their respective majority nations.

In practical terms, a government's policies ought to fit the characteristics deemed important for a citizenry's identity. This can be seen as an investment in the citizens' loyalty to the government. A policy that would not fit the characteristics of a citizenry's identity would be a disinvestment in the loyalty of the citizens (A. Breton and Wintrobe 1982, 74). Governments want to preserve or increase their citizenry's loyalty because its gives them more leverage to implement the policies that are important to them, or policies that would otherwise be unpopular (or simply because they like the power that they can potentially impose on their citizenry). Put differently, when the time comes to implement a new policy, less marketing will be required on the part of the government thanks to an existing loyalty. This concurs with Margaret Levi's conclusion from her study of military service (i.e., conscriptions) in France, Britain, the U.S.A., Canada, New Zealand, and Australia, according to which citizens will be loyal to their government provided the latter makes credible commitments (based on historical precedents) and uses fair/legitimate procedures for implementing public policy (Levi 1997, 20-21). The competition between majority nation's and minority nation's governments for their citizens' loyalty does occur through public policies because these are all that citizens have to assess governments. What the citizens see of their governments are their actions. Citizens thus can only assess their governments based on their actions, that is, based on 
their public policies.

At the equilibrium, both the central and the minority nation governments represent the citizens, in a differentiated and complementary way. Citizens are loyal to both governments, although each belongs to a specific sphere, that is, takes care of policy fields separately from the other government. Otherwise, citizens would be loyal to only one government for all policy fields: if citizens were loyal to only the minority nation government, then the minority nation would secede; if citizens were loyal to only the majority nation government, then the minority nationalism would not survive. The one of these three possibilities that guarantees the highest stability is the first one, as the other two are paths towards never-ending confrontation between the minority nation government and the majority nation one.

Thus, at the equilibrium, one may envision that the minority nation government specializes, for example, in linguistic policy, while the central government enacts policies in monetary regulation. At the equilibrium, the minority nation government of Catalonia will carry matters in $c_{1}, c_{2}, c_{3}$, and $c_{4}$ and the government of Spain as a whole will be in charge of $\mathrm{s}_{1}$ and $\mathrm{s}_{2}$.

This dissertation argues that, the more incremental the minority nation's requests towards the majority nation are, the more likely the minority nation is to be granted more powers. Therefore, incrementalism is a tactic that the minority nation's government can use to obtain more powers from the majority nation's government. Why is incrementalism a better way than radical change or demands for achieving more powers for a minority 
nation? Firstly, smaller changes are easier for the central government. Smaller changes require less work on the part of the civil service, or administration, of the government. Charles Lindblom claims that:

"[incremental politics] reduces the stakes in each political controversy, thus encouraging losers to bear their losses without disrupting the political system. It helps maintain the vague general consensus on basic values (because no specific policy issue ever centrally poses a challenge to them) that many people believe is necessary for widespread voluntary acceptance of democratic government" $(1979,520)$.

Otherwise said, "[incremental steps] do not rock the boat, do not stir up the great antagonisms and paralyzing schisms as do proposals for more drastic change" (Lindblom 1979, 520). Indeed, smaller changes are also smoother politically. Other provinces in Canada or other AC's in Spain are less likely to complain when Québec or Catalonia is granted more small powers than if the change is larger. Opposition parties are, too, less likely to complain if the change is small - other issues on the agenda will look more pressing than a little more power transferred to Québec or Catalonia.

Of course, sometimes, even a small change will be interpreted like a big change. As an illustration, when Catalonia added symbolically that it was a "nationality" in the preamble of its revised Statute of Autonomy of 2006, many voices complained in Spain (Marín 2010). In strategic terms, the central government might frame all powers granted to the minority nation as small changes. For example, when Canada's Prime Minister Harper declared Québec a "nation" in 2006, his office did not release a press communiqué (Gouvernement du Canada 2006) and the news was downplayed even in Québec (Brun 2006).

Secondly, smaller changes foster success, which itself fosters success. A 
cooperative action that leads to the alignment of the majority nation's and the minority nation's policies in one field will encourage both sides to repeat this cooperation. Both can appreciate that this cooperation is more pleasant that confrontation, and both want to continue on this path. Success breeds success. In game theory with a repeated game when the two players do not know how many times the game will be played, the most beneficial strategy for both players in the long run is to cooperate rather than to defect (Axelrod 1992). In this "tit for tat" game, the cooperative action is responded to by a cooperative action.

The reasoning behind cooperation as the best strategy is simple. If player A does not cooperate once, he earns higher benefits. Yet, player B will likely retaliate and not cooperate next time or the next few times. Player A has higher earnings when player B cooperates, no matter whether player A cooperates or not. The two players can continue not cooperating, but the earnings are lower than if both cooperated. Since each player can retaliate the non-cooperation of the other player and since each player knows that the other player can retaliate later and even multiple times (provided the game is over the long run), eventually, they will both cooperate every time they play. Transposed to the relationship between minority and majority nations' governments, each government is encouraged to cooperate with the other, that is, to use cooperative or neutral actions that do not disturb the policy of the other government. Otherwise, their earnings will be lower in the form of time and resources spent in confrontation (political and judicial), which will allow them less time and resources to implement policies that are important for them. Yet, there will not always be continuous cooperation between the two 
governments. The opposite of continuous cooperation and its usual corollary, incrementalism, is confrontation and its usual corollary, big changes in policy. Generally, a minority nation's government or a majority nation's government will enact a policy action that constitutes a big step when the public agenda brings it among its priorities. Jones claims that the "collective attentiveness" is brief and reports research by Shaw and McCombs that found that the public agenda can be occupied by at most seven issues at a time. This is representative of the big changes that took place both in Catalonia-Spain and in Québec-Canada. When Catalonia put in place its 2008 National Agreement on Immigration, the issue of immigration had already been at the forefront of the public agenda for a few years. As an illustration, former President of Catalonia Jordi Pujol said that managing immigration was crucial for the future of Catalonia in 2006 (Boire and Roy 2009). As another illustration of the concern of Catalans about immigration, one may simply look at one of Catalonia's main daily newspapers, La Vanguardia. The famous (very visible) journalist Lluís Foix published in 2008 an article titled "Blaming the immigrant" (author's translation) in which he described how most political parties of Spain blame (condemn) immigrants for the problems within the country and the AC. He writes: "It is very dangerous, the language of the discourse over immigration that since a few years has dominated the Spanish public opinion" (Foix 2008, author's translation). Foix cites leaders of the main political parties of Spain (that is, PP and PSOE, Partido Socialista Obrero Español) and criticizes their public statements regarding immigrants. What Foix's text describes is a concern across Spain that immigrants are a cost for the country. In Catalonia specifically, this concern is enlarged because Catalans were (and 
still are) concerned about immigrants coming to their $\mathrm{AC}$ and not learning their language, not embracing their identity. When Catalonia requested more power in immigration in 2006 with the revised Statute of Autonomy and again in 2008 with the National Agreement on Immigration, this big step in immigration policy was catalyzed by public opinion.

Québec-Canada can also illustrate the big step that occurs when an issue is prominent on the public agenda. In 1985, when Prime Minister Mulroney signed the "Entente entre le gouvernement du Québec et le gouvernement du Canada relative au Sommet francophone" with Québec, the issue of Québec in international forums was also part of the public agenda. In fact, the issue of the relations between Québec and Ottawa was at the forefront of public agenda since the province had, in 1982, been the only one that had not signed the Constitution Act. The macro-confrontation that occupied the two governments was widely discussed in the public agenda. Moreover, Mulroney ran his elections on a platform that Canada would significantly increase international trade (Parti progressiste-conservateur du Canada 1984). The 1984 program of the party read: "Nous allons lutter contre le protectionnisme mondial et appuyer la tenue d'une nouvelle ronde de négociations multilatérales dans le cadre du GATT (Accord général sur les tarifs douaniers et le commerce) en 1985 ou 1986" (Parti progressiste-conservateur du Canada 1984, 43). And this was to happen in collaboration with provinces: "Nous allons travailler en étroite collaboration avec les gouvernements provinciaux et les industries régionales pour lancer des initiatives locales qui vont à la fois accroître les exportations et renforcer l'économie des régions" (Parti progressiste-conservateur du Canada 1984, 43). Arguably, 
Mulroney was elected partially due to his promise of bringing back Québec in the Constitution "with honour and enthusiasm." This example, the 1985 agreement between Ottawa and Québec on international forums, was a big step in a public policy field, foreign relations, and shows that big steps can sometimes take place without confrontation. In sum, a big step - that is, a major policy action in a policy field - occurs when a policy field is brought into the public agenda. Most times, these big changes, as opposed to small changes, will be accompanied by confrontation between the two governments for reasons discussed above.

Specifically, confrontation (and, usually, its corollary, that is, a big step in a policy action) will occur in three main situations. First, at various points in time, one of the two governments will perceive the circumstances as being favorable to it. In these moments, perhaps the other government is vulnerable or perhaps there is a momentum of some sort. ${ }^{9}$ For example, when Catalonia enacted its Linguistic Policy Act in 1998 - a confrontational action - it thought that it had a chance of making a big step forward in its linguistic policy. Catalonia had learned from the disputed clauses of the previous language law and integrated the changes, ensuring that the next law would not be challenged in court (Mar-Molinero 2000, 165). Also, the Catalan political party, the CiU, was important in maintaining the Madrid government in power (Mar-Molinero 2000, 167). ${ }^{10}$ Indeed, the Spanish government did not retaliate the Catalan action.

Second, the minority government will use confrontation to advance policies in a

9 This is partly inspired by Keohane and Nye (2001) who claim, in particular, that a state has power when it is sensitive to coming changes and when other states are more vulnerable than it is.

10 The selection of Aznar as the president of Spain by the Cortes, following the 1996 general election, was possible thanks to a coalition of the political parties PP (156 deputies), CiU (16 deputies), PNV (Partido Nacionalista Vasco, 5 deputies), and CC (Coalición Canaria, 4 deputies) (Lozano 2011). The CiU was one of the main political parties of Catalonia - without its support, Aznar could not have a coalition. 
significant way, that is, with a big step, when it thinks that it does not have a choice. As an illustration, when Québec put in place the Gérin-Lajoie doctrine in 1965, it was a confrontational action in foreign policy, that is, Ottawa's policy in the same field was being challenged. It could not have been an incremental action. Québec wanted to be present on international forums; Ottawa did not want Québec present. This first step had to be a big one; it could not have been incremental. Confrontational actions followed in both camps. Nevertheless, both governments eventually returned to cooperative and neutral actions in the 2000's. This is representative of what was argued earlier: both players go back to cooperation because it yields higher earnings in the long term. For either player, it is more profitable to eventually forgive the other player's confrontation than to keep on not cooperating.

As another example, when Barcelona voted its new Statute of Autonomy in 2006, the changes proposed were not incremental in linguistic, foreign, and immigration policies, and they were also all-encompassing: Barcelona wanted much more power from Madrid. One would argue that Barcelona did not have a choice, that it could not request incremental changes in these three policy domains separately. To take the example of foreign policy alone, Barcelona wanted more say for its own jurisdictions on the international scene. It requested, all at once, a bilateral commission with Madrid, a seat at UNESCO, and the right to ask Madrid to sign international treaties related to its own jurisdictions. Could Barcelona have demanded these changes in a more incremental manner? This change corresponded with what Barcelona was seeing within other minority nations (such as Québec and Flanders). Moreover, Barcelona had obtained the 
consensus of its population via a referendum and approval from the Cortes, the Spanish Parliament (Turp 2010). Thus, this dissertation would argue that, no, it could not use incrementalism. Unlike the cooperation that eventually followed the Gérin-Lajoie doctrine in Québec-Canada, the revised Statute of Autonomy in 2006 led to a third type of confrontation, that is, macro-confrontation.

In some cases, macro-confrontation between the minority and the majority nations' governments is inevitable. When Québec held a referendum in 1980 and 1995, there was confrontation between Québec and Ottawa and it impacted all policy fields. It could hardly have been otherwise given the serious menace of a political breakdown of the country that was in the air. The same is happening between Barcelona and Madrid as of Summer 2013: the tension between Catalonia and Spain is very acute. The judgment of the Constitutional Court in 2010 over the revised Statute of Autonomy of Catalonia of 2006 dismantled many if not most of Catalonia's actions to develop its linguistic, foreign, and immigration policies. Spurred by this judgment and the economic crisis, there exists a separation menace in Catalonia. Many districts of Catalonia have held referendums since September of 2012 and then declared themselves, in accordance with the polls, Territori Català Lliure, that is, Free Catalan Territory. Some Spanish personalities have vehemently shown their ideas against Catalan independence. For example, the head of the Spanish Army, Francisco Alamán Castro, when asked about Catalonia's independence, replied: "Catalonia's independence? Over my dead body"11 (Fort 2012; La Vanguardia 2012). This current macro-confrontation between Catalonia and Spain prevails across all policy fields studied in this dissertation and was inevitable given the judgment of the

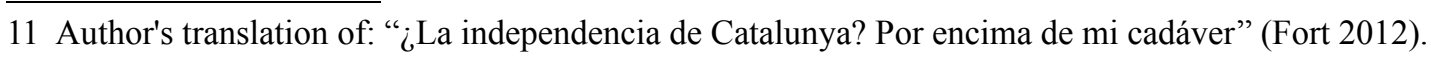


Constitutional Court and the fiscal constraints. In 2010, as Catalonia thought that it would have more powers in linguistic, foreign, and immigration policies, the Constitutional Court rejected its aspirations. On top of that, Madrid will not reimburse the money it owes Catalonia and has developed a rhetoric of making the AC's guilty of "overspending" (García 2012a).

\subsection{Methodology}

This dissertation examines three policy areas over time: language, foreign affairs, and immigration. These choices are mainly informed by Keating (1996). Keating's Nations against the State: The New Politics of Nationalism in Quebec, Catalonia and Scotland (1996) is pivotal in the academic literature on minority nationalism. It is one of the first books attempting an empirical study of comparing minority nationalisms in industrialized countries. Keating's main claim is that minority nationalism is a corollary of modernization $^{12}$ :

"The argument presented here is that nationalism is precisely a mechanism for coping with these [modernization's] dilemmas. It is a way of linking the individual to the collective; for bridging the past and future, tradition and modernity; for reconciling the universal with the particular. This explains its ambiguities and contradictions, reflecting these factors in the modern condition itself. It also links the discrete domains into which modernization divides human existence; the political, the economic, the social and the cultural" $(1996,2)$.

As expressed earlier in this chapter, with modernization, the state is being challenged and, either as a cause or as a result, minority nationalism has been emerging in

12 Keating's (1996) definition of "modernization" as a time period could not be found. In the book, the period of change of the state is not expressed explicitly. I assume it commenced in the 1960's, which makes Keating's definition of "modernization" different than that of other authors discussed earlier in this chapter (who referred to the industrialization in the $18^{\text {th }}$ century). 
the industrialized world. There are multiple illustrations of the lessened power of the central state: it can no longer easily assimilate its population because technology blends borders and lowers the cost of cultural production as well as transmission; it cannot gain as much legitimacy by claiming to create economic wealth because globalization lessens its capacity to act unilaterally; nor can it promote itself by a larger-than-its-neighbors welfare net; it can hardly act "to regulate land use, to segregate economic activities and to control environmental change" (33); the war threat that could be used to strengthen national unity has been replaced by international diplomacy; and international organizations lower the state's capacity in some competences (Keating 1996, chap. 2). This is where minority nationalism appears: "For the most part, the peripheral nationalisms of developed western societies represent attempts to come to terms with the changing constellation of power and to reconstitute politics on a territorial basis which is legitimated historically but which can be used to confront contemporary political and economic realities" (Keating 1996, 53).

From Keating's book, at least two main factors can be identified as determining the type of minority nationalism - that is, autonomist (arguing for more powers for the minority nation's government) or separatist (arguing for a sovereign country for the minority nation) - met by the majority nationalism. First is the "character of the majority nationalism" (Keating 1996, 20). For example, a majority nationalism that recognizes multiple identities rather than one "national" identity will most likely face smoother minority nationalism (Keating 1996, 24). Second are the "circumstances of the time" (Keating 1996, 20). In other words, some random events impact the type of minority 
nationalism. For example, as Catalonia and Spain face the Constitutional Court's judgment of 2010, the economic crisis affects their rapport differently than if there had been no financial struggle. Spain claims to have no room in its finances to pay back a debt it owes Catalonia. Catalonia claims to be faced with the crisis because of Spain's bad management of its fiscal revenues. Without the current crisis, there is little doubt that Catalonia's nationalism would not be as agitated as it currently is.

Keating identifies three policy fields involved in the "nation-building project" of the three cases he studies (Québec, Catalonia, and Scotland): economic; social culture and language; and international relations $(1996,55)$. His main conclusion is that Québécois, Catalan, and Scottish nationalisms have been built thanks to these policy areas: "They are the result of nation-building strategies, conducted within the shell of the existing state; and they draw on historic traditions and identities" (Keating 1996, 217). Restating his central argument in the conclusion, the author confirms that they are a way of apprehending the state in the contemporary world: "National culture is promoted and developed, not as a hegemonic set of ideas, but as a mechanism for promoting common values while permitting debate on the nature of the society itself" (Keating 1996, 219). In brief, according to Keating (1996), minority nationalism exists because the state has less power than before the 1960's - it is a compensation instrument.

\subsubsection{Rationale for the choice of public policies}

Language policy is ubiquitously recognized as a core element of national identity in the literature on minority nationalism, and is at stake in minority nations' demands (Kymlicka 2001b). It is also the minority government's jurisdiction in both countries and it is not 
managed the same way in Canada and Spain. The Official Languages Act of Canada renders the country officially bilingual from coast to coast (Canada 1985b); Spain's Constitution states that all Spaniards have the duty to know Castilian, while letting AC's apply bilingualism if they wish (Cortes Generales de España 1978). The second policy area, foreign affairs, is also very prominent in the literature on minority nations. Although foreign affairs are officially part of the central government's jurisdiction in both Canada and Spain, both national minorities are very active in this field (Paquin 2004). Moreover, international actors may play a role in the powers accorded to minority nations: while the Maastricht Treaty "forces" Spain to give some apparent powers to Catalonia through the EU's Committee of the Regions (Keating 2004, 99), Québec has benefited from France's support to develop its international presence (Bernier 1996). Finally, immigration seems relevant. Immigration policy is related to linguistic policy. In order to maintain their language in the long term, and thus their national identity, minority nations must ensure that immigrants choose to learn the minority nation's language. This observed necessity was an impetus in the case of the Charter of the French Language in Québec in 1977. Immigration policy is also related to foreign policy. To look "good" on the international scene, minority nations must demonstrate that they are contemporary societies that can thrive while accepting immigrants. Furthermore, just like their respective majority nations, minority nations need immigrants to ensure demographic-economic development. ${ }^{13}$

13 The argument according to which immigration benefits economic development has recently been contradicted by the essay Le Remède imaginaire: Pourquoi l'immigration ne sauvera pas le Québec (Dubreuil et Marois 2011). It has not led to much political debate about the current immigration policy in Québec, but most media mentioned it. 


\subsubsection{Classification of the competition via public policies}

The actions related to each public policy are classified on a continuum depending on the nature of competition. The actions rank from cooperative to confrontational as illustrated below.

Illustration 1: Continuum of competition

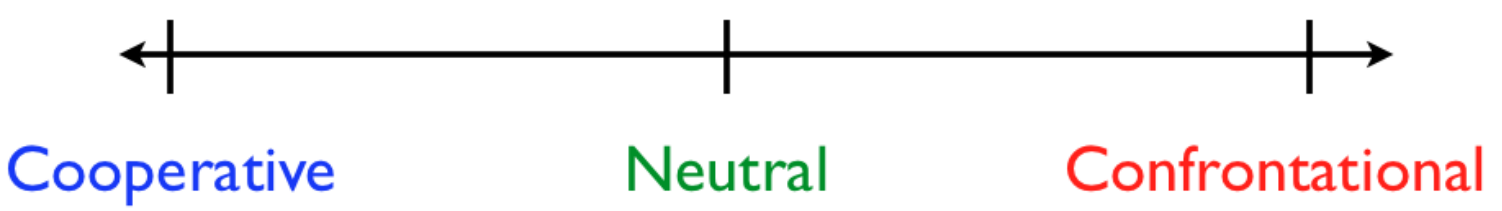

Each action of a policy field is labeled as "cooperative," "neutral," or "confrontational." The labeling is done according to whether the action gears the policy of the government that takes it closer to the other government's policy or farther from it. If the two governments' policies in one field are close, then citizens will be able to be loyal to both governments. However, if the two governments' policies in one field are far from each other or contradict one another, then citizens face conflict and must take sides between the two policies that the two governments present.

A "cooperative" action completes or reinforces the current policy of the other government, thus citizens can be loyal to both governments. A "neutral" action does not affect the policy of the other government; it is often informative or of a lesser impact. It does not affect to which government the citizens are loyal. A "confrontational" action offers an alternative to the policy of the other government; it is in contrast with the government's policy, and forces citizens to decide to which government they are loyal. 
Cooperative and neutral changes are more likely to be incremental than confrontational changes. Neither of them disrupts the other government's policy in a given field. They are incremental by definition because they do not represent big steps. If they did represent big steps, then they would be more likely to suggest an alternative to the other government's policy - they would be confrontational rather than cooperative or neutral. The premise is that ranking the actions for each public policy in this manner will allow for generalizations.

As the next empirical chapters will demonstrate, cooperative and neutral actions are generally followed by actions of a similar nature by the other government. On the contrary, confrontational actions by one government usually lead to a series of such actions by one or the two governments. Moreover, in the long run, cooperative and neutral actions tend to yield more powers for the minority nation's government.

\subsubsection{Interviews with civil servants}

This dissertation was informed partly through nineteen interviews with civil servants working in one of the three public policy fields of language, foreign relations, and immigration. The list of interviews is displayed in Appendix A of this dissertation.

These interviews proved fruitful for the dissertation. They were conducted after the core of the dissertation was written and were thus used in three main ways. First, they were used to confirm specific information on policy actions, such as particular relations between civil servants of the minority nation's and the majority nation's governments. For example, in terms of foreign relations, the role played by Catalonia in the EU remained 
unclear after the literature review. Most of the literature claimed that Catalonia had large powers in the EU's institutions, while it was not specific. The interviews evidenced that the powers of Catalonia were rather smaller than read otherwise in the academic literature. (This is discussed in chapter 4.) Second, the interviews were used to inform the current macro-confrontation occurring between Catalonia and Spain. Even though one can read newspapers from Ottawa, there is nothing quite like having the tensions described by an enthusiastic Catalan civil servant who provides a synthesis of the important elements of confrontation. Third, the interviews were used to discuss the model described in this chapter.

\subsection{Conclusion}

The empirical chapters that follow are centered on the competition that occurs between the minority nation's government and the majority nation's government via public policy. The two governments compete for the loyalty of the citizens. Governments want this loyalty because it gives them power to enact specific policies about which they care. They try to obtain this loyalty through public policy actions that will please the citizens. Citizens give their loyalty to the government that represents their identity the best because they want their descendants to have the same attributes as them. They believe that their descendants will be more fulfilled if they do so (altruistic explanation) or do not want to have to change in order to communicate with their descendants (self-interested explanation).

The minority nation's government is likely to gain more power in the long run if it enacts actions that induce incremental changes in public policy, that is, if it uses 
incrementalism as a tactic to obtain more powers from the majority nation's government. Incremental changes are cooperative or neutral, that is, are changes that do not make the minority nation's policy an alternative to the other government's policy. These changes appear smaller to the majority nation's government and to potential opponents (in the civil service or in other provinces or AC's). The success brought by incremental changes encourages further cooperation between the minority nation and the majority nation. Part of the central government's task to facilitate a long-term cooperation with the minority nation's government consists in making changes appear small to other provinces or AC's. Even when these changes are indeed incremental, other provinces or AC's might envision them as large and important.

There are three situations when incremental changes are not possible. Some policies require wide changes in order to be valid and macro-confrontation leads to inevitable confrontation between the two governments in most policy fields. Sometimes, a minority nation sees the circumstances as being favorable to a big step. At other times, a minority nation's government thinks that it has an advantage or thinks that it does not have a choice but to further its policy, thus it tries to develop its policy with a substantial step. This most likely leads to confrontational for a certain time between the two governments. Yet, both eventually return to cooperation. Cooperation is more beneficial for each government in the long term: each can avoid spending resources and time on confrontation. There is another situation when confrontation occurs. When the confrontation between the two governments does not resolve in cooperation, when a minority nation's government does not see any other issue, macro-confrontation comes 
up. The tension between the two governments is then palpable across policy fields and the minority nation's government will usually decide or threaten to go ahead with a referendum on sovereignty.

Eventually, three outcomes are possible. Either the citizens give their loyalty entirely to the minority nation, which leads to independence; or they give it entirely to the majority nation, which means the disappearance of the minority nationalism; or the minority nation's government and the majority nation's government split the policy fields.

The following chapters describe the policy actions that constitute public policy in all three fields of language, foreign relations, and immigration. In each chapter and for each couple of minority nation's and majority nation's governments (that is, QuébecCanada and Catalonia-Spain), a time line presents the policy actions and identified whether they are confrontational (red), neutral (green), or cooperative (blue). The model predicts that a minority nation's government that uses incremental changes, that is, cooperative or neutral actions, will obtain more powers from the majority nation's government in the long term than a minority nation's government that presents multiple demands at the same time. The equilibrium is reached when the two governments split the public policy fields (each taking care of some) or when the minority nation's government separates from the majority nation's government, or, alternatively, when the minority nationalism terminates. This model is unique in two ways. First, it describes the competition between a minority nation's and a majority nation's governments (QuébecCanada and Catalonia-Spain) via the use of public policy, that is, by decomposing three public policy fields into policy actions. Second, it offers a potential model for 
understanding other minority nations in industrialized countries. 


\section{Competition through linguistic policy}

This chapter describes the competition in Québec-Canada and in Catalonia-Spain, in light of the model presented earlier, for the specific field of linguistic policy.

Linguistic policy is of vital importance for minority nations. In the case of most industrialized countries, language is the main characteristic that minority nations cite as a difference from the majority nation. ${ }^{14}$ (Scotland constitutes the main exception to this assertion..$\left.^{15}\right)$

At first sight, the linguistic policies of Québec and Canada appear to conflict. Québec's policy dwells on making its territory primarily French in every sphere of public life. Canada aims at supporting the individual rights of its citizens to speak French or English. In practice, this means supporting the French minorities outside of Québec and the English minority in Québec. There is no constitutional recognition by the central government of Québec as a minority nation nor of the specificity of its language. ${ }^{16}$ From the same superficial perspective, the linguistic policies of Catalonia and Spain seem to complement each other. Catalonia claims that its territory is Catalan and, very much like Québec, aims at making Catalan the language in every sphere of public life. Spain, on the other hand, affirms that every citizen has the duty to know Castilian - a premise that

14 Race is arguably a more visible characteristic than language. In the industrialized countries, the most significant use of the ethnicity rhetoric in a nationalist discourse was in the Basque movement a century ago. Basque nationalism was developed under Sabino Arana (1865-1903) who praised the purity of the Basque blood (Conversi 2000) (Lecours 2007). Mainstream Basque nationalism does not resort to this argument nowadays.

15 Less than 4\% of the population of Scotland speaks Scots or Scottish Gaelic according to Leclerc (2008).

16 On November 27 of 2006, the Parliament of Canada unanimously voted a motion stipulating "That the Québécois form a nation within a united Canada." It was not accompanied by any additional rights for Québec. But it could potentially be used in future debates over a reform of the Senate (strengthening the opposition of Québec to equal number of seats for each province), a right to speak in international forums (more than other provinces), or in a Supreme Court decision on the possible infringement of provincial jurisdictions in Québec (Brun 2006). 
allows the central government to address everyone in this language. ${ }^{17}$

Aside from this first-sight analysis, how do the minority and majority nations' governments interact when it comes to linguistic policy? How have the competitive dynamics played out since the rise of nationalism in the 1970's?

The rest of this chapter is divided into two parts, following the respective cases studied. It begins by describing the linguistic policies of Québec and Canada since the 1960 's, the period that corresponds to the rise of the Québec nationalistic movement. Then, it describes the linguistic policies of Catalonia and Spain since the late 1970's, commencing with the end of Franco's dictatorship. Finally, it presents the results in a time line summarizing the actions for each case.

After a historical review, the events of a linguistic policy are placed in a time line in which the actions are ascribed to one of three categories: cooperative, neutral, and confrontational. This chapter aims to depict the retaliatory competition that takes place in the two cases chosen. In a dynamic of tit-for-tat or zigzag, each government seems to respond to the other government's action by moving forward towards one extreme of the continuum. The pace of the minority nation's demands allows one to predict the response from the majority nation. The more gradual the demands from the minority nation, the more likely the majority nation is to acquiesce.

17 This dissertation will not discuss directly the protection of the linguistic minorities within Québec and Catalonia. In Québec, since 1983, an amendment to the Charter allows municipalities where more than $50 \%$ of the population is Anglophone to be labeled "bilingual" and the Native communities and languages have been protected since 1975, and more officially in the Charter. In Catalonia, protection is granted to the Aranese, a variant of Occitan spoken by roughly 4,000 people. Without trying to disguise the variety that exists within Québec and Catalonia, this dissertation nonetheless seeks a modelized vision of the dynamics, thus focuses on the minority nation of Québec, that is, its Francophone population, and on the minority nation of Catalonia, that is, its Catalan-speaking population. 


\subsection{Linguistic policies in Québec and in Canada}

From the 1960's to the 1990's, linguistic policies in Québec and in Canada epitomized the constitutional struggle that characterized Canada's politics. It was a period of high political tension, with climaxes around the two referendums, during which the integrity of the country was seriously contested. From the 1960 's to the late 1970 's, the linguistic policies of Québec and Canada were increasingly confrontational, culminating with the 1980 referendum. The 1980's and the 1990's were similarly confrontational, interrupted by constitutional discussions. The status of linguistic policies in Québec and Canada currently seems (mostly) settled. This section will offer a historical description of the linguistic policies of Québec and Canada from the 1960's to the present.

\subsubsection{Before the 1960's}

Before studying the period that interests us, a brief historical summary of Québec is warranted. The colonization of the Americas by France commenced in 1608 with the arrival of Samuel de Champlain. France then occupied a vast part of the Americas including the then-called Louisiana. The Treaty of Paris in 1763 mandated that France cede the territory then called Canada (presently corresponding to parts of Québec) to Great Britain. ${ }^{18}$ The British common law replaced all civil laws; as a result, Catholic Canadians (namely, those of French descent) lost access to public office (charges publiques). In 1774, the Québec Act reestablished French civil laws, but nothing was specified on the status of languages. In 1791, Canada was divided into Lower Canada (mainly French-speaking) and Upper Canada (mainly English-speaking) - again with no 18 The Treaty of Paris is available here: http://www.axl.cefan.ulaval.ca/amnord/cndtraite_Paris_1763.htm 
stipulation on the status of languages. Following the Rebellions of 1837-1838 in Lower and Upper Canadas - during which citizens led by Louis-Joseph Papineau and William Lyon Mackenzie asked for less (British) colonial domination of Canada - London sent Lord Durham to assess the situation. His report recommended the assimilation of French Canadians, the union of the two Canadas, and a unique English-functioning parliament. Durham's rationale was that French Canadians were dependent on English Canadians for their economic well-being and that the current difference between the two peoples was the cause of political problems (Ajzenstat 2007; Craig 2007; Laforest 2007).

London listened to Durham. The Union Act of 1840 stipulated, in article 41, that English was the sole official language of Canada. Protests against this article abounded, so much that it was revoked in 1848. But the real recognition of French in Canada arrived in 1867, with the BNA Act. The Canadian constitution stipulated that the provinces were granted rights that would preserve the minority nation: namely, justice (civil law was maintained in Québec while the rest of Canada worked under common law), and education (in order to maintain the Catholic faith in Québec) were henceforth under the jurisdiction of provinces (Pelletier 2008, 9-21). Bilingualism, in Québec and Ottawa parliaments, as well as before federal and Québec's courts, was mandated under article 133.

The first clear statement of a political desire of national autonomy can be attributed to Premier of Québec Honoré Mercier (1887-1891) who wanted Québec to be "une nation française et catholique" in 1887. Québec's intellectuals also promoted nationalism in their works, and many associations advocating it were created. 
Legislation promoting French in Québec first came into force in 1910, with the Lavergne Law that stipulated that public utility companies had to offer bilingual (as opposed to monolingual English) services in Québec.

Meanwhile, in the rest of Canada, teaching children French became discouraged: Nova Scotia stopped funding Catholic French schools in 1864; New Brunswick doubled the tax for French schools starting in 1871 and this decision was not revoked by the federal Parliament; Prince Edward Island enacted a law creating one unique school system, mandatory, non confessional, and monolingual Anglophone in 1877; Manitoba impeded French schools and the use of French in justice and in its Parliament altogether in 1890 (Official Language Act) even though its creation in 1870 (article 22 of the Manitoba Act) stipulated the opposite, and fully prohibited the use of French in schools in 1916; the Northwest Territories made English the only language of justice and schools in 1892 even though the Act on NWT of 1877 guaranteed bilingualism in its Parliaments and tribunals; French had no protection in Alberta when the province was created in 1905 (even though it was recognized as an official language in 1877 under the Act on NWT); from 1929 onwards, English was the only language in schools of Saskatchewan and Alberta $^{19}$; and Ontario prohibited French after the second grade in schools in 1912 (Bylaw 17) and the article 93 of the BNA Act proved to be of no use to prevent this decision (Arès 1967, 563; Leclerc 2011).

In 1917, the Judicial Committee of the Privy Council declared that religious - not linguistic - rights were guaranteed by article 93 of the $B N A$ Act, and that, while article

19 Alberta and Saskatchewan stopped being part of the Northwest Territories, thus becoming provinces, in 1905. 
133 of the BNA Act guaranteed linguistic rights, it did not do so in terms of education. In short, French schools were not protected under the BNA Act (Arès 1967, 540). When Newfoundland joined Canada, in 1949, no protection was planned for the French minority (Arès 1967, 548).

Until the 1960's (and for a few years/decades afterwards depending on the measuring tool used), the socioeconomic status in Québec (particularly for Francophones) was lower than in most of Canada (Vaillancourt et al. 2007). In fact, French Québécois' relative status was similar to that of American Blacks: in 1961, French Québécois earned 52\% of the salary of English Québécois and Black Americans earned $54 \%$ of the salary of White Americans (Fortin 2010, 2). Part of the so-called Great Darkness era occurred under Premier Maurice Duplessis who ruled Québec from 1936 to 1939 and from 1944 until his death in 1959. He was fiercely opposed to state interventionism, allowing the Catholic Church to govern education, welfare, healthcare, and social norms (Laporte 1960, 139). The subsequent era of Québec's history is referred to as the Quiet Revolution, which was characterized by: 1) wide reforms in education, welfare, and Québec's state apparatus; 2) a renewal of the nationalist movement; and 3) the decline of the Catholic Church in Québec (Gélinas 2007, 336). All that in a short period (Linteau 2000, 34-5).

\subsubsection{After the 1960's}

Most historians agree that the Quiet Revolution was a turning point for Québec's nationalism. Plourde and Georgeault write that: "La Révolution tranquille fait sauter le couvercle et donne libre cours à un vigoureux discours d'affirmation et de revendication 
sur la langue, en fonction des inégalités dont sont victimes les Canadiens français" (2008, 35). The government in Québec became active in all fields of public policy, replacing the Church as the dominant institution in society. This switch was most sweeping in education - the ministère de l'Éducation was created in 1964 - but the government became more active in numerous facets of the society, nationalizing Hydro-Québec (1963), creating the pension plan Régie des rentes (1965), the Caisse de dépôt et de placement (1965), and others. The government's intervention in the standardization of French spoken in Québec was substantial: it created the Office de la langue française the same year as the ministère des Affaires culturelles (1961).

\subsubsection{Commission royale d'enquête sur l'enseignement dans la province de Québec (1961)}

In 1961, the government established the Commission royale d'enquête sur l'enseignement dans la province de Québec (also called the Parent Commission). The Commission's recommendations were twofold. First, it recommended the improvement of French language curriculum in schools. Second, it recommended the intervention of the government of Québec to protect the status of French in the public sphere: "Le gouvernement du Québec tout entier doit [...] adopter des mesures très fermes pour protéger le français non seulement dans les écoles et universités, mais dans toute la vie publique. C'est particulièrement urgent à Montréal" (Parent 1965, t.2, vol.3, chap.XII, p.44-5, par.621).

Signs of nationalism appeared everywhere among Québec's population. The Rassemblement pour l'indépendance nationale (RIN) published the pamphlet titled "Le 
bilinguisme qui nous tue" in 1962. From 1963 to 1965, the Société Saint-Jean-Baptiste de Montréal led the "Opération visage français" and the RIN used the Black American "sit in" technique to force Anglophone companies to allow for customers to be served in French. In 1967, the Mouvement Souveraineté-Association was created, followed the next year by the PQ. The 1965 "Livre blanc sur la culture" by Minister Pierre Laporte suggested that French be made the only official language of Québec, but Premier Jean Lesage blocked its publication (Robert 2008, 304). The General Estates of French Canada were organized in 1966, 1967, and 1969 by the Ligue d'action nationale; its participants adopted a resolution according to which Québec was entitled to self-determination and planned on writing a constitution for Québec. The World Exposition of 1967 in Montréal gave visibility to Québec, and Charles de Gaulle's "Vive le Québec libre !" triggered Québec's self-interest for its language and status.

\subsubsection{Royal Commission on Bilingualism and Biculturalism (1963)}

Faced with a growing nationalism in Québec, the federal government decided to intervene. André Laurendeau criticized in the newspaper Le Devoir the "crumbs" (miettes) granted to French Canadians. He wrote about the French Canadian problem and the separatist menace:

"il y a le malaise canadien-français, de plus en plus ressenti, de plus en plus aigu. L'estimerait-on si peu important qu'on puisse se permettre de le laisser pourrir indéfiniment? À l'heure actuelle, ce champ est abandonné aux séparatistes; les autres se contentent de dire qu'il y aurait lieu de réformer la Confédération; mais personne ne dit comment et jusqu'où" (Laurendeau 1962).

Laurendeau recommended a commission of inquiry on bilingualism. Lester B. Pearson, 
Prime Minister of Canada, established the Royal Commission on Bilingualism and Biculturalism (also called the Laurendeau-Dunton Commission) - and invited Laurendeau to co-preside it - in 1963.

This commission constituted the beginning of the intervention of the federal government in linguistic matters: "Ce sera la première intervention publique majeure d'un gouvernement canadien dans les questions de langue" (Gémar 2008, 311). The mandate of the Royal Commission on Bilingualism and Biculturalism was to study bilingualism in the federal civil service, the role of institutions (public and private) in the promotion of bilingualism, and the means to foster bilingualism within the population. Among its conclusions, it stated that Francophones held far fewer top federal government positions than Anglophones, that education for French minorities outside of Québec did not measure up to schooling provided for Anglophones in Québec, and that $95 \%$ of Francophones lived in Québec, New Brunswick or Ontario. One of its conclusions (from the preliminary report) was that:

"All that we [the members of the Commission] have seen and heard has led us to the conviction that Canada is in the most critical period of its history since Confederation. We believe that there is a crisis, in the sense that Canada has come to a time when decisions must be taken and developments must occur leading either to its break-up, or to a new set of conditions for its future existence" (Royal Commission on Bilingualism and Biculturalism 1965, 133, par.129).

The commission recommended that, given the principle of equal partnership between the "two founding peoples," federal institutions, that is, those shared by all Canadians, had to be bilingual (Dunton, Laurendeau, and Gagnon 1967, 91). It specifically recommended that French and English be formally declared official languages in the Parliament, federal 
courts, and the federal (civil service) government.

\subsubsection{Crisis of Saint-Léonard (1968-9)}

In the Saint-Léonard district of Montréal, $90 \%$ of the immigrant population preferred bilingual classes over French classes. The result was that most of the so-instructed children mastered only the English language. The School Board decided that it had to remedy this situation and, in June of 1968, announced it would abolish bilingual classes and gradually offer only classes in French. Allophone parents (backed up by the Anglophone population) protested. In response to their dissatisfaction, Premier JeanJacques Bertrand introduced, in November of 1968, Bill 85 which permitted free choice of the language of instruction (Leclerc 2010a). Consequently, the decision of the School Board was nullified and immigrants could choose to be instructed in English.

A violent demonstration of Francophone and Italian parents led to the promulgation of the Riot Act in September of 1969. The Crisis of Saint-Léonard instigated action in linguistic policy by both governments for a decade, as discussed in the following section.

\subsubsection{Commission of Inquiry on the Situation of the French Language and Linguistic Rights in Québec (1968)}

The federal government had its Laurendeau-Dunton Commission on linguistic policy and the Québec government needed to show that it was active in this field too. The government of Québec had to decide what to do on its own territory (Gémar 2008, 312). In December of 1968, Premier Jean-Jacques Bertrand established the Commission of 
Inquiry on the Situation of the French Language and Linguistic Rights in Québec (Gendron Commission). Its mandate was to recommend actions to protect: "1- les droits linguistiques de la majorité aussi bien que la protection des droits des minorités. 2- le plein épanouissement et la diffusion de la langue française au Québec dans tous les secteurs d'activités à la fois sur le plan éducatif, culturel, social et économique" (Lesage 1968, 1). Its report, submitted in 1973, recommended that French be the common and official language of Québec. The rationale invoked was that there was little hope that the adult immigrant would make any effort to learn French if the language were not necessary to find work - the situation in Saint-Léonard epitomized this diglossia between

French and English, particularly prevalent in Montréal. According to Gémar, the report of this commission was the first substantial document that set the foundations of a serious linguistic policy in Québec (2008, 313).

The report seemed too weak in the public opinion; it recommended the proclamation of French as the "official language" of Québec and, at the same time, French and English as "national languages" of Québec (Gémar 2008, 314). Nevertheless, it led to the enactment of Québec's Official Language Act (Act 22) in 1974, which is discussed later in this chapter.

\subsubsection{Official Languages Act (1969)}

Ottawa was facing a growing nationalist menace from Québec: the Crisis of SaintLéonard, perturbations by the Front de libération du Québec (FLQ), and more independence movements (Gémar 2008, 315). It was an opportunity to create a new element of the Canadian identity: the federal government would become the protector of 
linguistic minorities across the country. The government of Canada enacted the Official Languages Act in June of 1969. The Official Languages Act stipulates that: a) the federal civil service has to offer bilingual services and work in both languages in specific regions (mainly Ottawa-Gatineau, Montréal, and New Brunswick); b) that the Parliament functions in both languages; that both languages can be used in federal $\operatorname{courts}^{20}$; c) that Francophone minorities outside Québec and Anglophone minorities within Québec are be protected by the federal government; and d) that both versions of laws would have equal validity (Canada 1985b).

This corresponds to the beginning of the divergence between the visions of linguistic policies between Québec and Ottawa. The former believed that a bilingual Canada was a vain or irrelevant wish and that the only way to ensure that some people could live in French in Canada was to build a strong Québec where French dominated in all spheres. The latter sought to offer bilingual services a mari usque ad mare; this was the new foundation of Canada, including in Québec.

\subsubsection{Act to promote the French Language in Québec (1969)}

Premier Jean-Jacques Bertrand's Bill 85 (in 1968) infuriated the Francophone majority and did not solve the conflict over the language of instruction in Québec. The Premier was planning on waiting for the report of the Gendron Commission (in 1973) before presenting another linguistic bill. But tensions between Francophones and Anglophones (in tune with Allophones) - the Crisis of Saint-Léonard - induced him to present the Act

20 Article 16 of the Official Languages Act stipulates that the judge has to understand the language(s) chosen by the parties for proceedings without an interpreter, except in the case of the Supreme Court. Bill C-232 died on the Order Paper (Hudon et Lecomte 2011). 
to promote the French Language in Québec (Bill 63) in November of 1969.

The act had three objectives: a) promotion of French in the workplace; b) French as the main language in public signs; and c) mandatory teaching of French in English schools. Nevertheless, article two of the Act to promote the French Language in Québec stipulated that parents may choose the language of instruction of their children:

"[Courses] shall be given in the English language to any child for whom his parents or the persons acting in their stead so request at his enrolment; the curricula and examinations must ensure a working knowledge of the French language to such children and the Minister shall take the measures necessary for such purpose" (Québec 1969).

Thus, it pleased the Allophone and Anglophone populations, but angered Francophones who thought that the law was insufficient to protect their language in the long-run (Robert 2008, 306-7,314).

\subsubsection{Policy of Multiculturalism (1971)}

In his "Announcement of Implementation of Policy of Multiculturalism within Bilingual

Framework" in 1971, Trudeau dissociated language from culture:

"For although there are two official languages, there is no official culture, nor does any ethnic group take precedence over any other. No citizen or group of citizens is other than Canadian, and all should be treated fairly. The royal commission [on Bilingualism and Biculturalism] was guided by the belief that adherence to one's ethnic group is influenced not so much by one's origin or mother tongue as by one's sense of belonging to the group, and by what the commission calls the group's 'collective will to exist'. The government shares this belief" (Canada 1971).

Leslie Pal recalls the objective of the policy: "The 1971 policy affirmed in essence that while Canada would be officially bilingual it would never be merely bicultural and that it valued its multicultural character" (1995a, 115). Via 
multiculturalism, a Canadian cultural duality would be avoided, thus lessening the relevance of the Québec nationalistic argument that Francophones were mostly located in its territory (Pal 1995a, 115).

Most scholars contend that a "diglossed" (or second-rank) language needs the support of a nation to be maintained and to flourish. Language planning and standardization are important for states to maintain their specific language (McColl Millar 2005, 30). Stephen May claims that the "nation-state congruence" has become important since the French Revolution, since which time we associate the nation with a single language and a corresponding (thus also unique) culture (May 2008). In the same vein, Will Kymlicka posits that language is determinant in the construction of democratic political communities; the culture and the nation are the core units of the political liberal theory $(2001 \mathrm{~b}, 16)$. He claims that, "Language is one of the fundamental markers of people's identity, and so people view any denigration in the public status of their mothertongue as an assault on their identity" $(2001 \mathrm{~b}, 217)$.

The objectives of this federal "Policy of Multiculturalism" were essentially to promote the emancipation of all cultural groups and to help immigrants learn one of the two official languages. For any given immigrant, it is more immediately rewarding to learn the language of the dominant group than the language of the minority group (the diglossed language), thus the effect of this policy was to widen the gap between the two groups.

Réjean Pelletier argues that the 1969 federal Official Languages Act and the 1971 federal "Policy of Multiculturalism" did not protect the language and culture of Québec, 
and that they led to the enactment of the Charter of the French Language in $1977 . \mathrm{He}$ writes that:

"La première [the Official Languages Act] reconnaissait deux langues officielles, l'autre [the "Policy of Multiculturalism"] plusieurs cultures, marginalisant ainsi la culture québécoise et dissociant la langue et la culture, comme si la langue n'était pas le support d'une culture dans une communauté donnée" (Pelletier 2008, 68).

\subsubsection{Official Language Act (1974)}

Gémar writes that Québec's 1974 Official Language Act was "[sans] doute pour donner la riposte à la loi fédérale [the Official Languages Act of 1969]" (Gémar 2008, 316). This act was the first to proclaim French as the official language of Québec. In this sense, it went further than the recommendations of the Gendron Commission, which stated that French and English should be "national languages" of Québec. Henceforth, the federal and provincial governments would not see eye to eye on linguistic policy.

The Official Language Act (Bill 22) in 1974 made French mandatory in public signs; forced businesses to "francisize"; restricted English schools to children who already knew English; and prioritized the French version of Québec laws. It also created the Régie de la langue française to monitor the implementation of "francisation" programs and to carry out inquiries. Moreover, article 41 stated that: "Pupils must have a sufficient knowledge of the language of instruction to receive their instruction in that language. Pupils who do not have a sufficient knowledge of any of the languages of instruction must receive their instruction in French" (Québec 1974).

Gémar comments that this law highlighted the gap between Francophones and Anglophones: while the former judged it too weak, the latter thought it was 
discriminatory (Gémar 2008, 316).

\subsubsection{Charter of the French Language (1977)}

The PQ came in power in Québec in 1976. The "Énoncé de politique" (also called "White Book") titled "La politique québécoise de la langue française" that accompanied the Charter of the French Language points out the federal impotency, in the eyes of the Québec government, to protect Francophones. It states that the federal institutional bilingual policy resembles an "écran de fumée qui masque bien mal le fait que le Canada et l'Amérique sont anglophones" (G. Rocher 2008, 341).

The root of the Charter of the French Language is the fear of assimilation, which is derived from three main concerns. First, French should survive in North America in order to protect linguistic diversity. Here, the argument is the same as for biodiversity: humans should try to preserve as much diversity as possible, because one living organism that does not seem necessary today might prove to be of an extreme importance, that we cannot now foresee, later. Second, the federal government cannot be counted on for the protection of the French language. There was a concern that without clear protection and support for the French language in Québec, the province might gradually become assimilated into the North American Anglophone majority - the process was already happening with Francophone minorities in the rest of the country. Third, FrancoCanadians outside Québec in 1977 could not always send their children to French schools (as discussed before). Québécois wanted institutions to pass their mother-tongue down through generations; they knew that individual will does not suffice to protect a language. In sum, assimilation was understood as a proceeding unabated for Francophones across 
Canada who had not made sure that their provincial government guaranteed the preservation of their language and identity. Richard Arès writes in 1967:

"Si l'expérience d'un siècle de vie française en dehors du Québec démontre quelque chose, c'est bien ceci: les garanties accordées aux Franco-Canadiens par la Constitution de 1867 ont été tout à fait insuffisantes. Les Pères canadiens-français de la Confédération ont manqué de clairvoyance et de fermeté; ils n'ont pas suffisamment tenu compte des groupes français des autres provinces et les ont livrés sans défense aux attaques des fanatiques de l'impérialisme assimilateur"' $(1967,541)$.

Evidence can be found in the diglossia - that is, the social ranking gap between two varieties of the same language within a society, or between two different languages that existed between Francophones and Anglophones in Québec. Indeed, Québec's Comité interministériel sur la situation de la langue française claims that the threats were as follows in 1977:

- economic: most management jobs were filled by monolingual Anglophones, and Francophones were much poorer than their English counterparts;

- political: the Québec government believed that the Canadian Constitution was meant to assimilate French speakers; and

- demographic: French Québécois' birthrates were declining and immigrants chose to speak English rather than French (Québec 1996).

The Charter made French the unique language of Québec. The initial version imposed the exclusive use of French in public signs, posters, and commercial advertising; required all enterprises of fifty of more employees to be "franciséed"; allowed English education only to children whose parents had received their primary education in English in Québec; and made the French version of laws the only official one. Through the years 
(and judicial conflicts), the Charter has been amended so that most of its dispositions have been weakened: commercial signs must be predominantly in French, the "francisation" programs are not as compelling, English education is accessible provided parents or siblings of one have received more than $50 \%$ of their pre-college education in English in Canada, and English versions of laws are as valid as French versions. ${ }^{21}$

The Charter also created four organizations. First, the Office de la langue française is responsible for the linguistic "officialisation," terminology, and "francisation" programs. It also monitors the linguistic situation in Québec and publishes a corresponding report every five years. It "shall see to it that French is the normal and everyday language of work, communication, commerce and business in the civil administration and in enterprises. The Office may, among other things, take any appropriate measure to promote French" (Québec 1977). Second, within the Office de la langue française, the Commission de surveillance de la langue française was renamed the Commission de protection de la langue française in 1984. Third, the Charter also created the Conseil supérieur de la langue française. Its mission is to "advise the Minister responsible for the administration of this Act on any matter relating to the French language in Québec" (Québec 1977). Fourth, the Charter created the Commission de toponymie. Its role is to promote the French character of place names in Québec while respecting the popular usage and the history attached to a name (Dorion 2008, 386-7).

21 The 2002 Act to amend the Charter of the French language (Bill 104) prevented parents from contouring the Charter by sending their children one year in an English private school and then in an English public school. It was judged unconstitutional by the Supreme Court of Canada in 2009. Bill 115 replaced it in 2010. It stipulates that a child may attend English public schools provided that he has attended a private English school for three years. 


\subsubsection{Changes to the Charter of the French Language by the Supreme Court and federal legislation}

The Charter was challenged in courts and its initial dispositions in terms of education, advertising as well as English and French versions of the law have been lessened over the years. Here is a description of the changes that were made.

Education. The Charter initially stated that only children whose parents had received primary education in English in Québec could attend an English school. The federal government considered that this infringed on the free movement underlying the federal system, but there was nothing in the 1867 Constitution to invalidate this disposition of the Charter. Instead, the federal government and the nine provinces added article 23 in the 1982 Constitution to counteract the Charter (Woehrling 2008, 356). Henceforth, children from outside Québec can receive their education in English in Québec if their parents or siblings have received more than $50 \%$ of their pre-college education in English anywhere in Canada.

Advertising. In the judgment Ford v. Québec (Attorney General) in 1988, the Supreme Court of Canada judged that French could be obliged in advertising, but that other languages could not be proscribed (Cour suprême du Canada 1988). Premier Bourassa used the Notwithstanding Clause (by enacting Act 178), that is, article 33 of the 1982 Constitution, to avoid applying the judgment of the Supreme Court and to enforce uniquely French advertising. Act 178 was revoked after an outcry of Anglophones across Canada and the United Nations' Human Rights Committee declared that it was infringing freedom of expression (Leclerc 2010b; Woehrling 2008, 357-9). 
English and French versions of the law. In Attorney General of Quebec v. Blaikie et al. (1981), the Supreme Court of Canada judged unconstitutional (according to article 133 of the BNA Act) the dispositions of the Charter according to which French would be the sole language of acts and rules in Québec. Those who wrote the Charter were aware of this infringement, but, given that Manitoba had declared itself monolingual English in 1890 (even though its 1870 provincial constitution claimed that both languages had the same value), thought that article 133 of the BNA Act could be modified by a mere provincial law. The Supreme Court invalidated both Manitoba's 1890 law and the Charter's disposition.

In 1993, Québec's Act to Amend the Charter of the French Language (Bill 86) was enacted. It stated that French was the predominant language in public and private signs (advertising); it included the 1982 obligations regarding English education; and stipulated that English and French versions of the law would have the same value.

\subsubsection{Constitution Act (1982)}

In response to the Charter of the French Language in 1977 and to the election of the separatist PQ in 1976, the Prime Minister of Canada Pierre Trudeau repatriated the constitution and enacted the 1982 Constitution Act (Pal 1995b, 45-7). ${ }^{22}$ Since the 1960's, Québec had wanted more powers within the Canadian federation and a formal recognition that it was a nation ${ }^{23}$, despite reservations by the rest of Canada to these

22 Québec is the only province that has always refused to sign the Charter of Rights and Freedoms.

23 Perhaps the simplest version of these demands is described as the "five conditions" under which Québec would agree to sign the Constitution Act. They were stipulated by Gil Rémillard, then Québec's minister of Canadian Intergovernmental Affairs, on May 9 of 1986: explicit recognition of Québec as a distinct society, guarantee of more powers in immigration, limitation of the federal power to spend, recognition of a veto right, and participation of Québec to the nomination of the Supreme Court judges (Rémillard 1986, 9). 
demands. Parallel to that, the Canadian government wanted to add a constitutional charter of rights to its constitution, but modifying the constitution required the consent from the British Parliament and many stakeholders thought that this would require the approval of Québec. After the sovereignty-association referendum of Québec in 1980, the province was in weak position. Moreover, the Supreme Court of Canada judged, in its $1981 \mathrm{Re}$ : Resolution to amend the Constitution and its 1982 Re: Objection by Quebec to a Resolution to amend the Constitution decisions, that Québec could not veto a constitutional change. During the Nuit des longs couteaux (November 4 of 1981), the federal government convinced all other provinces - while the Premier of Québec was sleeping - to adopt the Constitution Act which included the Charter of Rights and Freedoms (Woehrling 2009, 92-3).

The 1982 Constitution Act sets the core of the linguistic policy of the Canadian government. The Charter of Rights and Freedoms stipulates that English and French are the two official languages of Canada (art.16, 18, and 19); that citizens should have access to federal services in the language of their choice where the number (or the nature of the office) warrants it (art.20); that the province of New Brunswick is bilingual (art.16); and that primary and secondary education should be available in French and English where the numbers are sufficient (art.23). No territorial protection is granted to Francophones; nor is any geographical area designated as benefiting from a special protection for Francophones. Rather - and as is the case in most laws (Malloy 2005) - individual rights are guaranteed.

Also, the 1982 Constitution Act explicitly counteracted the Charter of the French 
Language. Article 73 of the original Charter of the French Language stipulated that Canadians from outside provinces settling in Québec had to send their children to a French school, unless a reciprocity agreement existed between Québec and the province they were from (Woehrling 2008, 356). This was unacceptable to federal authorities, who judged that it inhibited free circulation and movement throughout Canada. But nothing in the 1867 Constitution made this disposition illegal. Hence the 1982 Constitution, whose article 23 states that children may attend English school provided their parents or siblings have received more than $50 \%$ of their pre-college education in English in Canada. Article 23 of this 1982 act made it so that article 73 of the Charter of the French Language was in conflict with federal legislation. When it was brought up before the courts after 1982, article 73 of the Charter of the French Language was declared invalid (specifically, in the judgment of 1984, Attorney General (Quebec) v. Quebec Protestant School Boards).

\subsubsection{Official Languages Act (1985)}

In 1985, Prime Minister Brian Mulroney decided to revise the federal government's 1969 Official Languages Act. The 1985 act is the same as the one enacted in 1969, with the addition of the protection of linguistic minorities; it essentially enforces the protection of individual rights to speak and be educated in one's official language. The aim of this act was two-fold: to foster national unity and to support linguistic minorities across the country (Pal 1995b).

The Official Languages Act of 1985 states that English and French are equal languages of the Parliament and of federal courts; that communications and services should be executed in either language provided there is significant demand; that both 
mother-tongue speakers have equal opportunity in the federal government; and that the government will enhance the vitality of French and English minority communities and encourage the recognition of both languages in the country.

\subsubsection{Multiculturalism Act (1985)}

Not only did Ottawa revise its Official Languages Act in 1985, it also strengthened its multiculturalism statement of 1971 by enclosing it into a law. In 1985, the Parliament of Canada passed the Multiculturalism Act. The objective was to create a Canadian identity based on the recognition of a multitude of cultures and two languages:

"It is hereby declared to be the policy of the Government of Canada to [...] (i) preserve and enhance the use of languages other than English and French, while strengthening the status and use of the official languages of Canada; and (j) advance multiculturalism throughout Canada in harmony with the national commitment to the official languages of Canada" (Canada 1985a,

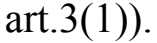

Notwithstanding the recognition of official bilingualism, Canadian multiculturalism is purportedly based on the idea that all citizens are equal (Citizenship and Immigration Canada 2008). This goes against the linguistic policy of Québec, based on the belief that a diglossed (dominated) language cannot survive without a strong culture. Otherwise said, nothing in the Multiculturalism Act takes into account the linguistic territorial agglomerations of Francophone citizens in Québec.

\subsection{Competing visions of linguistic policies}

The high point of linguistic policy in Québec is the Charter of the French Language. The

Charter aims at making the territory of Québec mainly French, and the cornerstone of 
this mission is to ensure immigrants speak French. The Charter is criticized by some for infringing on the individual rights of Anglophones to speak English or for immigrants to choose a language of instruction. Indeed, one may not advertise in English only nor send one's children to English school without having received English education in Canada. The linguistic policy is territorially-based; Québec, as a minority nation, is French and functions in this language. It enforces collective rights based on the argumentation that before French was enforced (before 1977), Francophones were subject to a serious diglossia (Vaillancourt et al. 2007) and the same would happen nowadays if French were not protected.

The core of linguistic policy in Canada is represented by the assemblage of the Official Languages Act, the Charter of Rights and Freedoms, and the Multiculturalism Act. The former two grant rights to all residents of Canada; one may address the federal civil service in either official language and thus linguistic minorities are protected (French minorities outside of Québec and English minorities within Québec). According to Michael Keating:

"The Bélanger-Campeau commission (1991) insisted that Quebec could not accept the 1982 Canadian constitution and charter of rights because it entrenched the equality of all Canadians on the same basis, thus denying Quebec's distinct society; its provisions for multiculturalism reduced the Québécois to one ethnic group among many; and the equality of provinces deprived Quebec of the means for promoting its distinct society" $(1996,75)$.

As for the Multiculturalism Act, it projects a Canadian identity built on multiple cultures, while attesting the two official languages. Both these laws are based on a logic of individual rights: across Canada, one may choose one's language to address the federal government. 
In sum, the premises of the Québécois linguistic policy and of the Canadian linguistic policy are not the same. The former is based on territory and collective rights; the latter is based on individual rights. While both Québec and Canada include French as a component of the identity of their nation's government, the former has only one language as part of its linguistic policy and the latter has two languages that are parts of its linguistic policy.

\subsubsection{Competition between Québec and Ottawa in linguistic policy}

The following time line lists the actions related to the linguistic policy in Québec and Canada since the 1960's. In the time line, each action is ascribed to one of three categories, in accordance with the definitions presented earlier. 
Illustration 2: Time Line of Actions in Linguistic Policy in Québec and Canada

Commission royale d'enquête sur l'enseignement dans la province de Québec

Commission of Inquiry on the Situation of the French Language

Act to promote the French Language

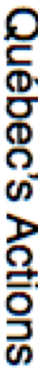

General Estates on the Situation and Future of the French Language

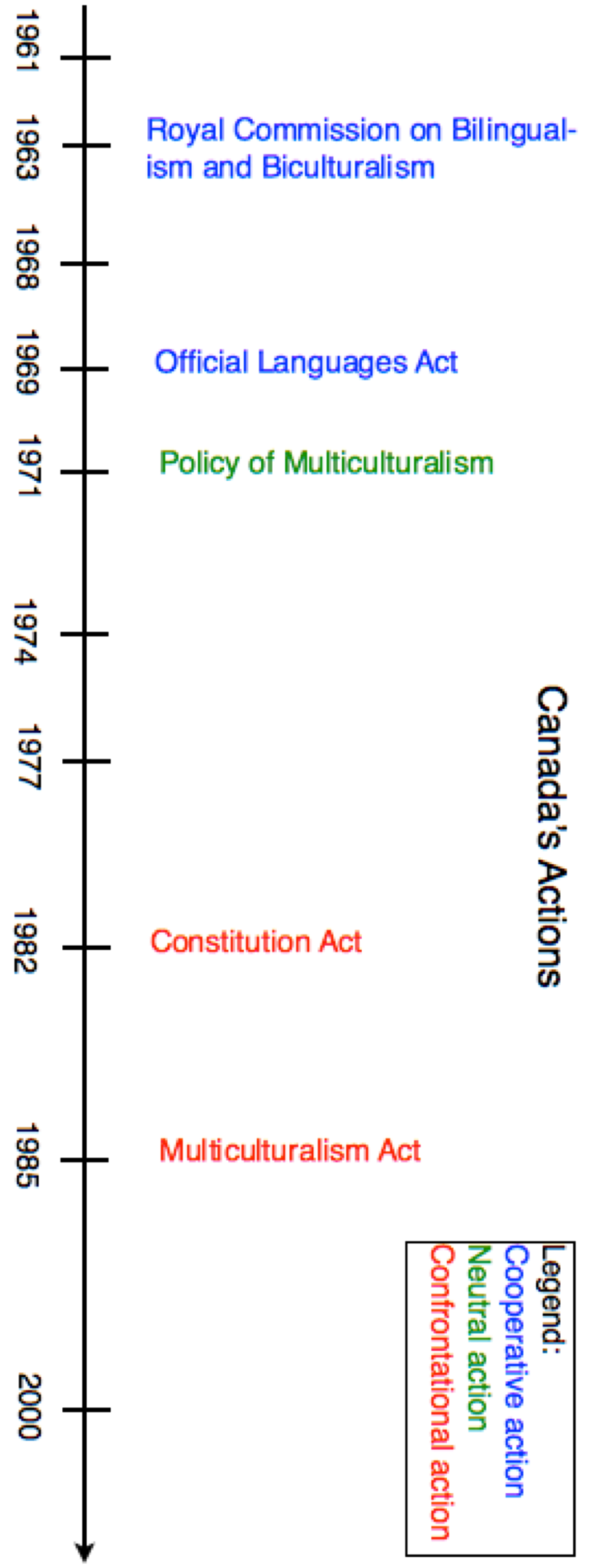


In the 1960 's, both governments engaged in cooperative actions. The situation changed in 1971 with the federal "Policy of Multiculturalism," which is considered a neutral action as it sought to promote one national identity - that is, an identity not based on language, but rather on the fact of being Canadian. Nevertheless, this action is not considered confrontational as it was accompanied by few consequences at the federal level. The provincial Charter of the French Language (1977) may be considered an confrontational action as it clearly opposed Ottawa's and Québec's linguistic policies. It was followed by a series of responses through the Constitution Act (1982) and the Multiculturalism Act (1985), which are also labelled as confrontational actions for reasons discussed earlier. The confrontational dynamics seem to have calmed down in the 2000's with an apparent absence of actions - except perhaps for the General Estates on the Situation and Future of the French Language (2000), which were ordered by the Government of Québec in 2000 and presided by Gérald Larose. The final report, released in 2001, lists a series of recommendations to promote, highlight, and advance French in Québec. A few of these could be deemed confrontational such as doing all possible against article 23 of the 1982 Constitution Act (Commission des États généraux sur la situation et l'avenir de la langue française au Québec 2001, 236). But the report got little public exposure and does not seem to be influencing the current government, nor the linguistic policy of Québec.

Since the 1990's, the federal and Québec governments have not interacted over linguistic policy. Interviews with both Guy Dumas, Interim Secretary from 1990 to 1995 and Associate Deputy Minister at the Secrétariat à la politique linguistique of Québec 
from 2000 to 2008, and Graham Fraser, Commissioner of Official Languages of Canada since 2006, were unambiguously clear: Québec and Ottawa have different linguistic policies and do not discuss them with one another. Contacts between civil servants of the federal and provincial governments are absent. Contacts between elected officials responsible for linguistic policy, on the rare occasions they occur, are only for the purpose of courtesy. Guy Dumas was active in six laws related to linguistic policy during his career; yet, he is unaware of any contacts with the federal government or other provinces on that topic. Graham Fraser asserted that the federal government does not want to give the impression that it is telling Québec how to act regarding its linguistic policy. Ottawa is measured in its actions that have to do with this policy field because it believes that linguistic policy is a sensitive topic within the population (Interview with Graham Fraser 2012; Interview with Guy Dumas 2012).

\subsection{Linguistic policies in Catalonia and in Spain}

Before the end of the Franco dictatorship in 1975, only Castilian was permitted in Spain. ${ }^{24}$ Afterwards, there was an acute memory of the oppression in Spain and an openness, a desire to fix the oppression, for linguistic minorities. From the late 1970's to the mid-1990's, linguistic minorities - with the Basque, the Catalan, and, to a lesser extent, the Galician minorities at the forefront - rebuilt their institutions, in what could be deemed a cooperation with the central state. From the mid-1990's to the early 2000 's, terrorist violence from the Basque ETA (Euskadi Ta Askatasuna) cooled down this

24 It should be noted that "Castilian" refers to what is usually called "Spanish" in North America. Under the expression "Spanish languages," all languages spoken in Spain are included: Castilian, Catalan (Valencian), Galician, Basque (Euskera), Asturian (Leonese), Aragonese, Aranese (Occitan), Extremaduran, and Fala. 
cooperation between minorities and the central state. Catalonia managed to keep a cooperative relationship with Madrid, perhaps due to the necessity for the central government of working in a coalition with the governing party of Catalonia. Since the 2000 's, the linguistic situation seems to have become more confrontational, with less agreeable decisions on both sides. This section will offer a historical description of the linguistic policies of Catalonia and Spain from the 1970's to the present.

\subsubsection{Before the 1970's}

Before the Bourbons' dynasty in 1715, non-Castilian regions of Spain were essentially autonomous. The Bourbons ended Catalan institutions and the status of noble Catalans. Catalans could hardly access the civil service or the army, thus their social ascension was accomplished through the industries (mainly textile). The 1812 Constitution sought to unify Spain and, as part of that project, Catalonia was spread across four provinces.

From the 1830 's to the 1890 's, Catalonia witnessed a Renaixença (a renaissance), that is, a movement whose core was the revival of Catalan in literature and culture in general. The Renaixença started with the poem "La Pàtria" by Bonaventura Carles Aribau in 1832, which essentially deplored that Catalan was disappearing from the literature. The Renaixença is now used as a basis for the spread of nationalism (Mar-Molinero 2000). According to Mar-Molinero, "This revival in their own cultural awareness, and an increasing frustration with the perceived backwardness of the politically-corrupt and primarily agricultural central Spanish state, fuelled the Catalan people's awakening interest in political as well as cultural issues" $(2000,43)$.

Parallel to this cultural movement, a pro-federalist political movement emerged, 
guided by the the book Las Nacionalidades (literally, The Nationalities) written by the Catalan Francesc Pi i Margall. This publication criticized the unitarian principle in Spain and proposed federalism. In 1886, Valentí Almirall published Lo Catalanisme (literally, The Catalanism) in which he exposed the Catalan language as the core value of the Catalan nationalism (Mar-Molinero 2000, 43-4).

The restoration of the monarchy in 1875 catalyzed demands for greater political recognition of Catalonia, for example, the first Congrés Catalanista was organized in 1880. In 1885, Catalan elites presented the Memorial de Greuges, which requested the defense of Catalonia, of its economy, of its traditional law, and of its language, to King Alfons XII. The First Republic of 1889 and its centralizing project commenced the political Catalan affirmation: political parties and interest groups placed the national question at the core of their actions. In 1892, the Unió Catalanista met in Manresa and agreed on the "bases" of a regional constitution for Catalonia (Mar-Molinero 2000, 44). In the same vein and also in 1892, Enric Prat de la Riba wrote La Nacionalitat Catalana (literally, The Catalan Nationality) in which he put the Catalan language at the core of the Catalan identity - and advocated Catalan nationalism without militating for Catalonia's independence (Mar-Molinero 2000, 45-6).

Prat de la Riba established the nationalist party Lliga (literally, the League) and was elected president of the Diputació (the local government) of Barcelona in 1907. Under Prat de la Riba, the Institut d'Estudis Catalans (literally, the Institute of Catalan Studies) was created to standardize Catalan. The linguist Pompeu Fabra remains as the main figure of standardization (orthography, grammar, and dictionary) of the language, 
working at the Institut from 1913 to 1932. Meanwhile, the four Catalan provinces Barcelona, Tarragona, Girona, and Lleida - merged in a larger organization, the Mancomunitat de Catalunya (which later became the Generalitat), and Prat de la Riba became its first president in 1914.

From 1923 to 1930, Spain was under the dictatorship of Primo de Rivera and this "put an abrupt stop to the flourishing Catalan culture and political nationalism" (MarMolinero 2000, 46). The use of Catalan was prohibited. Catalonia recovered its autonomy through the creation of its Generalitat in 1931, under the Second Republic (1931-36). The Civil War began in 1936.

Franco ended the Generalitat in 1938 and the use of Catalan was forbidden the following year. By prohibiting Catalan, Franco's dictatorship, from 1939 to 1975, arguably strengthened Catalan nationalism "with the Catalan language its central motif and point of resistance" (May 2008, 242). In the 1950's, publication in non-Castilian languages became more common and, in the 1960's, they could be taught in private centres. In 1973, the Education Act allowed Catalan to be taught, but only as a foreign language (Mar-Molinero 2000, 158). Under Franco, non-Castilian languages were portrayed as "inferior" to Castilian and "inconsequential" to the central state (MarMolinero 2000, 85).

In addition to language, economic success also contributed to strengthening Catalan nationalism: "[The] ongoing association of Catalan with economic dominance, even during the years of its political marginalisation, is certainly a key factor in its survival amounting, in effect, to a form of reverse diglossia within Catalonia” (May 2008, 243). 


\subsubsection{After the 1970's}

The transition to democracy in Spain began after Franco's dictatorship. Two days after his death, which occurred on November 20 of 1975, Juan Carlos was designated king of the country. He appointed Adolfo Suárez as his Prime Minister.

The suppression of non-Castilian languages under Franco is key to understanding the subsequent politics of language in the country afterwards. Indeed, the Spanish population associated Franco's dictatorship with the prohibition of non-Castilian languages. Thus, his policies arguably resulted in the promotion of Catalan later on:

"[Franco's] regime's clever propaganda drive made one costly mistake: the rejection and even ridicule of the minority languages became so closely associated with the ideology of the Franco regime that it also served as a point of reference around which to build the opposition to it. Language became a symbolic standard bearer for and against the regime" (MarMolinero 2000, 85).

\subsubsection{Constitution (1978)}

The Constitution of Spain was signed in 1978, during a period called the "transition" from Franco's dictatorship to a "state of communities." This agreement encouraged the creation of $17 \mathrm{AC}$ 's. Being recognized as an $\mathrm{AC}$ granted more jurisdictions to the regions, as stipulated in article 148 of the Constitution. Under article 143, regions had six months to fulfill the requirements (mainly, popular approval via referendums) allowing them to become an AC. The regions that fulfilled these requirements faster than other regions were thus labeled "historical autonomous communities": Catalonia, the Basque Country, and Galicia.

The core of the linguistic policy of Madrid is officially contained in article three 
of the 1978 Constitution, which states that:

"(1) Castilian is the official Spanish language of the State. All Spaniards have the duty to know it and the right to use it.

(2) The other Spanish languages shall also be official in the respective Selfgoverning [nowadays called 'Autonomous'] Communities in accordance with their Statutes.

(3) The richness of the different linguistic modalities of Spain is a cultural heritage which shall be specially respected and protected" (Cortes Generales de España 1978, preliminary title, section 3).

The first paragraph makes it possible for Madrid to communicate with its citizens in Castilian only. In other words, all Spaniards have the duty to learn Castilian and it can be used anywhere in the country. Under the second paragraph, Galicia, the Basque Country, and Catalonia have declared themselves bilingual. In other words, for Madrid, the non-Castilian Spanish languages can be "official in their "respective communities"” as long as Castilian is present throughout the country (Mar-Molinero 2000, 88-9).

\subsubsection{Statute of Autonomy (1979)}

In 1979, the Generalitat of Catalonia enacted its Estatut d'autonomia (henceforth called the Statute of Autonomy), in line with the prescription of the Spanish Constitution, as described earlier. It thus gained the advantages of becoming an $\mathrm{AC}$, that is, jurisdiction on the powers listed in article 148 of the Constitution. This Statute of Autonomy represents the basis of the linguistic policy in Catalonia.

The Statute of Autonomy of Catalonia contains the following language provisions:

"1) The own language of Catalonia is Catalan. 
2) Catalan is the official language of Catalonia, as Castilian is the official language of the whole of the Spanish State.

3) The Generalitat shall guarantee normal and official use of both languages, adopting all measures necessary to ensure they are known, and creating those conditions which shall make possible their full equality with regard to the duties and rights of the citizens of Catalonia.

4) The speech of the Valley of Aran shall be taught and shall receive special respect and protection" (article 3, translation by Pou Pujolràs $(2002,3)$ ).

In practical terms, Catalonia's Statute of Autonomy added Catalan as compulsory subject in all public schools of Catalonia (Mar-Molinero 2000, 159).

As for the expression "own language" of paragraph one, it is a literal translation from the Catalan "llengua pròpia." It refers to the language that symbolically represents the $\mathrm{AC}$, without necessarily being the official one from a legal perspective. Its genuine purpose is only later informed; indeed, although the expression is first mentioned in the 1979 Statute of Autonomy, it is only formally defined in the 1983 Normalization Law. There, in the 1979 document, it is explicated that Catalonia has one "llengua pròpia" and two official languages; hence, the Generalitat has the duty to promote and maintain the full equality of both (Generalitat de Catalunya 1983, introduction). This idea is later (in 1983) termed as "normalization," which refers to the "full equality" of the two languages, as understood by the government of Catalonia. Underlying this assertion of "full equality" of a dominant and a dominated language is the necessity of strongly promoting the dominated language, that is, Catalan. In the 1998 Linguistic Policy Act, "llengua pròpia" is - finally - defined officially. 


\subsubsection{Normalization Law (1983)}

In 1983, Catalonia decided it was time to strengthen its language, having been prohibited from doing so under Franco. The 1983 Llei de normalització lingüistica a Catalunya (henceforth called the Normalization Law) was replaced by the 1998 Linguistic Policy Act, but remains important historically to understand future linguistic policy actions.

The Normalization Law received enormous support from the Parliament of Catalonia and from the population (Mar-Molinero 2000, 93-4, 160). Mar-Molinero explains the reason for the strong support: "This was, after all, only eight years after the end of the Franco dictatorship and very many still identified political democratisation in general with the upgrading and promotion of the minority languages in particular" (MarMolinero 2000, 160). On top of that, Catalan was associated with social prestige and economic success in Catalonia, thus non-Catalan speakers were sympathetic to learning it (Mar-Molinero 2000, 161).

Catalonia was confronted with the weak presence of Catalan in everyday use, in education, and in means of communication. The law was created to end this linguistic imbalance between Castilian and Catalan in Catalonia. ${ }^{25}$ Thus, the recuperation of Catalan was perceived as a part of the reconstruction of Catalonia following Catalan's ban under Franco's dictatorship. ${ }^{26}$

The importance of the language for the $\mathrm{AC}$ was central. The introduction of the 1983 law commences with: "The Catalan language, fundamental element of the creation

25 "Per això aquesta Llei es proposa de superar l'actual desigualtat lingüística impulsant la normalització de l'ús de la llengua catalana en tot el territori de Catalunya" (Generalitat de Catalunya 1983, introduction).

26 "la recuperació de la llengua catalana com un dels factors fonamentals de la reconstrucció de Catalunya" (Generalitat de Catalunya 1983, introduction). 
of Catalonia, has always been the own language [of this autonomous community]" (Generalitat de Catalunya 1983, introduction, author's translation). Yet, this legislation was in accordance with the 1978 Spanish Constitution, whose article three stipulates that Castilian is the official language of the state, but that it is to be co-official with other languages in the autonomous communities, in accordance with their respective statutes of autonomy - exactly what the Catalan Statute of Autonomy (1979) stipulated in its own article three.

Article one of the 1983 Normalization Law listed the objectives of the law: "a) to protect and encourage the use of Catalan by all citizens; b) to give effect to the official use of Catalan; c) to normalize the use of Catalan in all means of communication; d) to ensure the increase of the knowledge of Catalan" (Generalitat de Catalunya 1983, art.1, author's translation). In order to achieve the first objective, the Normalization Law made Catalan the language of public administration and Parliament (Generalitat de Catalunya 1983, art.5-13). The Generalitat would provide Catalan courses to all civil servants (municipalities must do the same) and the Generalitat would commission the creation of an up-to-date map of Catalonia (Generalitat de Catalunya 1983, art.24-7). In terms of addressing the second objective, the Normalization Law stated that the Generalitat would promote the Catalan language and culture in the means of communication in order for it to become the language of normal use (Generalitat de Catalunya 1983, art.21). ${ }^{27}$ It would also promote Catalan in newspapers, on the radio, in theatre, in cinema, in books, and in other cultural manifestations (Generalitat de Catalunya 1983, art.22-3). As for the third objective, increasing the knowledge of Catalan, the Normalization Law targeted 27 "La llengua normalment emprada hi ha d'ésser la catalana" (Generalitat de Catalunya 1983, art.21). 
education. It stipulated that all children must be able to use ("normally and correctly") both official languages at the end of their basic instruction, although children may receive their education in their usual language, Castilian or Catalan (Generalitat de Catalunya 1983, art.14). In universities, professors and students may use the official language of their choice, but universities must offer classes on the Catalan language to insure the understanding of Catalan by those who do not (Generalitat de Catalunya 1983, art.16). Teachers must know both languages and the Generalitat would provide the necessary conditions for this to happen (Generalitat de Catalunya 1983, art.18-9). Finally, the Aranese language was to be protected in the Val d'Aran (Generalitat de Catalunya 1983, $\operatorname{art} 28)$.

After the Parliament of Catalonia voted in favor of the Normalization Law, the President of Spain, Felipe González, brought it before the Tribunal Constitucional (literally, the Constitutional Court), which invalidated two components of it. First, the Court decided that, in case of disagreement between the Castilian and the Catalan versions of the laws, the Catalan version could not be deemed superior (thus nullifying part of article 6.1 of the Normalization Law) judging that it would present a danger for judicial security (Tribunal Constitucional 1986, II.3). Second, the Executive Committee of the Generalitat de Catalonia would not be allowed to "exercise all political, administrative, and judicial actions to protect the Catalan rights of its citizens" (author's translation), nullifying article 4.2 of the Normalization Law. The Constitutional Court judged that "administrative and judicial actions" in article 4.2 were the jurisdiction of the state (Tribunal Constitucional 1986, II.2). 


\subsubsection{Law on the Education System (1990)}

In 1990, the Spanish government decided to revise its previous education law which dated back to 1970, that is, during the dictatorship of Franco. It issued the Ley Orgánica de Ordenación General del Sistema Educativo (LOGSE). This new law was necessary to follow the course of integration in the EU - diplomas had to be comparable between countries - and to adapt the curricula to broader contemporary needs. In that sense, the 1990 law recognized that "school curricula should be able to reflect more explicitly the features of their immediate environments and respond to their community needs" (MarMolinero 2000, 162). In other words, Madrid was leaving the task of deciding exact curricular objectives and content to schools, as long as they followed the LOGSE.

This law has since been replaced by the 2006 Ley Orgánica de Educación. Nevertheless, it remains important in the transition between the full centralization of education in Madrid and its partial decentralization with the autonomous communities. Indeed, the Generalitat saw the 1990 Law on the Education System as an encouragement to promote its culture and language in the school curriculum, as is demonstrated by the 1992 Catalan decree.

\subsubsection{Decree that establishes the structure of the mandatory education in Catalonia (1992)}

The 1990 Spanish Law on the Education System was the opportunity for Catalonia to develop parts of its curriculum that would better reflect the AC. In 1992, the Generalitat voted on the decree "Decret pel qual s'estableix l'ordenació general dels ensenyaments de l'educació infantil, l'educació primària i l'educació secundària obligatòria a Catalunya," 
establishing the norms of mandatory kindergarten (before six years of age), primary, and secondary (high school) education (Generalitat de Catalunya 1992). It made instruction in Catalan mandatory starting at the age of eight (with the exception of the Val d'Aran pupils), through the use of a more compulsory immersion education.

This latter element of the Catalan decree did not please Castilian speakers living in Catalonia and the consensus over the means to protect Catalan dissolved (MarMolinero 2000, 162). The opposition was epitomized by the article from Madrid's newspaper $A B C$ which headlined: "The same as Franco but the other way round: the persecution of Castilian in Catalonia" ("Igual que Franco, pero al revés: persecución del castellano en Cataluña" 1993, author's translation). The newspaper devoted many pages to this issue before the beginning of the school year, presenting the views of parents who refused to abide by the measure and thought that three hours of Castilian per week were insufficient for their children to be functional in the main language of Spain (Armora 1993, 72-75).

\subsubsection{Linguistic Policy Act (1998)}

Still trying to strengthen its language in the public sphere, the Catalan Parliament replaced, in 1998, the 1983 Normalization Law with the Llei de Politica Lingüistica (henceforth called the Linguistic Policy Act).

Mar-Molinero claims that the main addition of the 1998 Linguistic Policy Act consisted of the clarification of the meaning of "own language" ("llengua pròpia"), as stipulated in the 1979 Statute of Autonomy of Catalonia and stated in the 1983 legislation (2000, 165-6). The symbolic definition given to "own language" is that it singularizes the 
people of Catalonia (Generalitat de Catalunya 1998, art.2, par.1). The tangible consequences of this definition are explained. Being the "own language" of Catalonia, Catalan is:

“a) The language of all institutions of Catalonia, in particular that of the administration of the Generalitat, of the local administration, of public companies, of public services, of institutional means of communication, of education, and of toponymy.

b) The language of preferred use for the administration of the State of Catalonia (in the sense that it will itself determine), for other institutions, and, more broadly, for the companies and other entities that offer services to the public" (Generalitat de Catalunya 1998, art.2, par.2).

While the 1983 law focused on the knowledge of the language (model of persuasion), the 1998 act is more concerned with the legal and institutional status of Catalan (model of legislative enforcement), much like the Charter of the French Language in Québec (May 2008). One of the main objectives of the Linguistic Policy Act is to normalize and encourage the use of Catalan in public administration, in education, in media, in cultural industries, and in the socioeconomic world (Generalitat de Catalunya 1998, art.1c). To that effect, it stipulates - although in more detail - all of the articles of the 1983 Normalization Law. The main inclusions of practical importance are fourfold. ${ }^{28}$ First, private contracts and collective bargaining agreements (for unions) henceforth must be conducted in the official language chosen by the parties, or in both official languages in case of discordance (Generalitat de Catalunya 1998, art.15-6). Second, students must demonstrate oral and written knowledge of both Catalan and Castilian in order to be granted their secondary education - acceptable exceptions are to be determined by the

28 A striking change is contained in article 19 of the Linguistic Policy Act. According to it, one may request a modification to the civil registry so that the letter " $i$ " is added in-between one's two last names. It looks more Catalan than without it. 
Generalitat (Generalitat de Catalunya 1998, art.21; Mar-Molinero 2000, 167). Third, linguistic quotas are imposed on radio and television communications, as well as cinema (Generalitat de Catalunya 1998, art.26, 28). Fourth, firms must be able to offer services in both official languages to customers (Generalitat de Catalunya 1998, art.32). Many of these provisions include special protection for the Aranese language in the Val d'Aran.

As one could expect, the Linguistic Policy Act led to opposition from the rest of Spain. The debate was placed between the individual right of people to use Castilian anywhere in Spain, including in Catalonia - and the collective right to use Catalan, which can only be achieved via a confrontational action given the predominance of Castilian (Mar-Molinero 2000, 167-8). Mar-Molinero claims that the law deals with this conundrum. Article three of the Linguistic Policy Act writes that "Catalan is the official language of Catalonia, as is Castilian as well," protecting individual rights; article two of the same act stipulates that "Catalan is Catalonia's own language and distinguishes it as a people," thus making Catalan the language of the authorities and the language of the public sphere, hence protecting collective rights (Mar-Molinero 2000, 165-8).

\subsubsection{European Charter for Regional or Minority Languages (2001)}

The European Charter for Regional or Minority Languages was adopted by the Council of Europe in 1992. Spain ratified it in 2001 and it came into force in the country the same year. In Spain, a few languages were designated as "protected," including Catalan in Catalonia (Database for the European Charter for Regional or Minority Languages [No date]). The Charter prescribes actions vis-à-vis education, justice, public services, media, cultural activities, and economic relations, and highlights "the protection and promotion 
of regional or minority languages" (Council of Europe 1992).

In 2005, the Council of Europe's independent Committee of Experts - in charge of monitoring the application of the Charter - issued a recommendation to Spain about Catalonia, which was later supported by the the Committee of Ministers of the Council of Europe. The two Committees recommended that Spain comply with two articles of the Charter. First, with article nine of the Charter, requiring that an "adequate proportion" of Spain's judicial staff posted in Catalonia have a working knowledge of Catalan. Second, with article ten, requiring that the personnel of Spain's administration offices posted in Catalonia have a "working knowledge" of Catalan (Committee of Experts of the European Charter for Regional or Minority Languages 2005; Committee of Ministers of the Council of Europe 2005). In 2008, the same two Committees recommended the exact same two elements, with the addition of a third one: to "ensure the presence of all regional or minority languages in state owned public services" (Committee of Experts of the European Charter for Regional or Minority Languages 2008; Committee of Ministers of the Council of Europe 2008).

\subsubsection{New Statute of Autonomy (2006)}

These European recommendations - on judicial personnel and Spain's administrative staff posted in Catalonia - encouraged Catalonia to stipulate these in the revision of its Statute of Autonomy. In 2006, the Parliament of Catalonia voted a new Estatut d'autonomia de Catalunya (henceforth called the Statute of Autonomy), replacing that of 1979. With regard to linguistic policy, it is stated in the Preamble that:

"The civic and associative tradition of Catalonia has always underlined the 
importance of Catalan language and culture, of rights and duties, of knowledge, of training, of social cohesion, of sustainable development, and of equality of rights - and, especially today, of gender equality" (Generalitat de Catalunya 2006, 8, author's translation, bold added).

And this is linked to a much more powerful message, that of nationalism. In the Preamble, Catalonia is designated as a "nation":

"The Parliament of Catalonia, representing the sentiment and will of the citizenry of Catalonia, has defined Catalonia as a nation of an ample majority. The Spanish Constitution, in article two, recognizes the nation reality of Catalonia as a nationality" (Generalitat de Catalunya 2006, 9, author's translation, bold added).

This revised Statute held a very high importance in Catalan politics. It was voted on by the Parliament, and then approved by $74 \%$ of the electorate via referendum (Rioux 2006, A1). The emphasis, in the Preamble, is explicitly on what constitute the values of Catalonia. These have been agreed upon by the deputies of the Catalan Parliament and, later, by those of the Spanish Parliament (Colino 2009), and are meant to indicate what Catalonia's leaders are to focus on - language is at the forefront and Catalonia is a nation.

The expression "own language" is defined on two occasions in the new Statute. Firstly, "Own language and official languages" are discussed in article six. It is said that the own language of Catalonia is Catalan. In accord with what was stipulated in the 1998 Linguistic Policy Act, it is thus the language of normal use, of public administrations, of public communication, and of education. Both Catalan and Castilian are official languages in Catalonia - and discrimination based on language is forbidden. But the definition of "own language" goes one step further in the new Statute of Autonomy compared to the 1998 legislation. Article six defines Catalan as: "the language of normal and preferred use of public administrations and means of public communications in 
Catalonia, as well as the normally used language in the functioning and instruction of education" (Generalitat de Catalunya 2006, art.6.1, author's translation, bold added). Secondly, article 143 - labeled "Own language" and of lesser legislative importance stipulates that the Generalitat has exclusive jurisdiction over its own language, including the determination of its scope, its uses, its judicial effects on its own "officiality," and also over the linguistic normalization of Catalan (Generalitat de Catalunya 2006, art.143). The novelty of the 2006 definition of "own language" thus comes from the word "preferred" in article six; the use of this term indicates that the Generalitat aims at making Catalan more prevalent than Castilian in Catalonia. Article 143 merely acts as a reminder that the Generalitat will act in many facets to promote Catalan.

As for other short-term practical consequences, three elements are new in relation to the 1998 legislation. First, the Generalitat and the Spanish state must take necessary action to have Catalan recognized in the EU, and to have it used in international organizations and in cultural or linguistic international agreements (Generalitat de Catalunya 2006, art.6). Second, citizens have the right to communicate with the Administration of Justice in Catalan, without translation. In order for this to be functional, all personnel of the Administration of Justice must show sufficient knowledge of both official languages. Catalonia's citizens also have the right to communicate in written Catalan with the state's constitutional and judicial institutions (Generalitat de Catalunya 2006, art.33). Third, everyone has the right to be served (in written and oral speech) in either official language when using any government services, conducting business, and all public services (Generalitat de Catalunya 2006, art.34). 


\subsubsection{Sentence of the Constitutional Court (2010)}

Then in power under President José María Aznar López, the PP in Madrid disagreed with this revised Statute of Autonomy and brought the matter to the Constitutional Court of Spain in 2006, on the basis that some of its articles were unconstitutional. According to the PP, the new Statute of Catalonia is radical and sets the path for independence. ${ }^{29}$ Four years later, and after a series of political rumblings, the Constitutional Court finally gave its judgment (Barbeta 2010).

The stumbling block brought up by the new Statute of Catalonia for linguistic policy, is epitomized by the rejection of the first paragraph of article six. The Constitutional Court judged that Catalan could not be said to be the "preferred" language of Catalonia, as this would infringe on article 3.2 of the Constitution, which stipulates that there can only be one "official" language is Spain: Castilian (Tribunal Constitucional 2010, II.,par.14a). ${ }^{30}$ In other words, the government of Catalonia wants Catalan to be the main language of its $\mathrm{AC}$, while respecting the right of all citizens of Spain to speak Castilian, based on the belief that a minority language needs to be promoted in order to be maintained and strengthened. Madrid refuses any pre-eminence of a language other than Castilian, based on the belief (or fear) that the status of Castilian would be lessened (Tribunal Constitucional 2010, II,par.14a). ${ }^{31}$

29 From a presentation of the President of the PP of Cataluña, Alicia Sánchez-Camacho: "ahora que vivimos una radicalización de la política catalana con planteamientos para independizarse del resto de España, el PPC quiere salir de esta espiral nacionalista” (Partido Popular de Cataluña 2010).

30 "En efecto, el art. 3.2 CE no permite que los Estatutos de Autonomía proclamen la oficialidad de cualquier lengua española distinta del castellano" (Tribunal Constitucional 2010, II,par.14a).

31 "A diferencia de la noción de "normalidad", el concepto de "preferencia", por su propio tenor, trasciende la mera descripción de una realidad lingüística e implica la primacía de una lengua sobre otra en el territorio de la Comunidad Autónoma, imponiendo, en definitiva, la prescripción de un uso prioritario de una de ellas, en este caso, del catalán sobre el castellano, en perjuicio del equilibrio inexcusable entre dos lenguas igualmente oficiales y que en ningún caso pueden tener un trato 
Other articles of the 2006 Statute are also related to linguistic policy. The Court judged that article 33 , on the right to use Catalan with public administration and justice in Catalonia, was constitutional (Tribunal Constitucional 2010, II,par.21). As for article 34, on the right to use Catalan when conducting business in Catalonia, the Constitutional Court interpreted that this did not mean that businesses could be forced to serve customers in Catalan (Tribunal Constitucional 2010, II.,par.22).

The Constitutional Court also communicated a warning concerning article 35, which stipulates that Catalan is to be the language of normal use in instruction. The tribunal added that, even though the new Statute does not stipulate that Castilian is not to be a language of normal use in instruction, it should also be the co-official language of normal use in instruction (Tribunal Constitucional 2010, II.,par.24). This was not well received in Catalonia. La Vanguardia, one of the leading newspapers of Catalonia, outlined two elements from the judgment: a) the rejection by the Constitutional Court that the use of the word "nation" in the Preamble of the new Statute has any meaning (Tribunal Constitucional 2010, II.,par.7); and b) the obligation for both Castilian and Catalan to be languages of instruction and normal use in education ("El Constitucional rechaza la nación catalana y equipara el castellano al catalán como lengua vehicular en la enseñanza” 2010).

\subsection{Competing visions of linguistic policies}

The high water mark of the linguistic policy of Catalonia is the 2006 Statute of Autonomy; it seeks to make Catalan predominant over Castilian in Catalonia. Catalans

privilegiado" (Tribunal Constitucional 2010, II,par.14a). 
have been fighting since the end of Franco's dictatorship to promote their language on their territory. Under Franco's dictatorship, their language was forbidden. The hope is for a transitioned Spain, more tolerant of the cultural and identity fulfillment that they seek. This reference to history in the Catalan identity is clearly stated in the Preamble of the 2006 Statute, which offers the history of the nationalistic rights of Catalonia over the last millennium. And in order to make Catalan prevalent in Catalonia, the latter needs power over many jurisdictions that are currently in the hands of Madrid, exactly what the 2006 Statute requested.

The high point of the linguistic policy of Spain is the 1978 Constitution. Its article three stipulates that all Spaniards have the duty to know Spanish and that some AC's may have co-official languages, as is the case in Catalonia. However, Madrid refuses to recognize that there exist more than one nationality within Spain - as was indicated in the judgment of the Constitutional Court in 2010 - and, in the same vein, that a language other than Castilian could take predominance over the language of all Spaniards in any AC. This could be connected to article two of the Constitution, according to which Spain is "indivisible" and consists of only one ("unique") nation.

\subsubsection{Competition between Barcelona and Madrid in linguistic policy}

The following time line lists the actions related to the linguistic policy in Catalonia and Spain since the late 1970's. The definitions of the categories are as described previously. 
Illustration 3: Time Line of Actions in Linguistic Policy in Catalonia and Spain
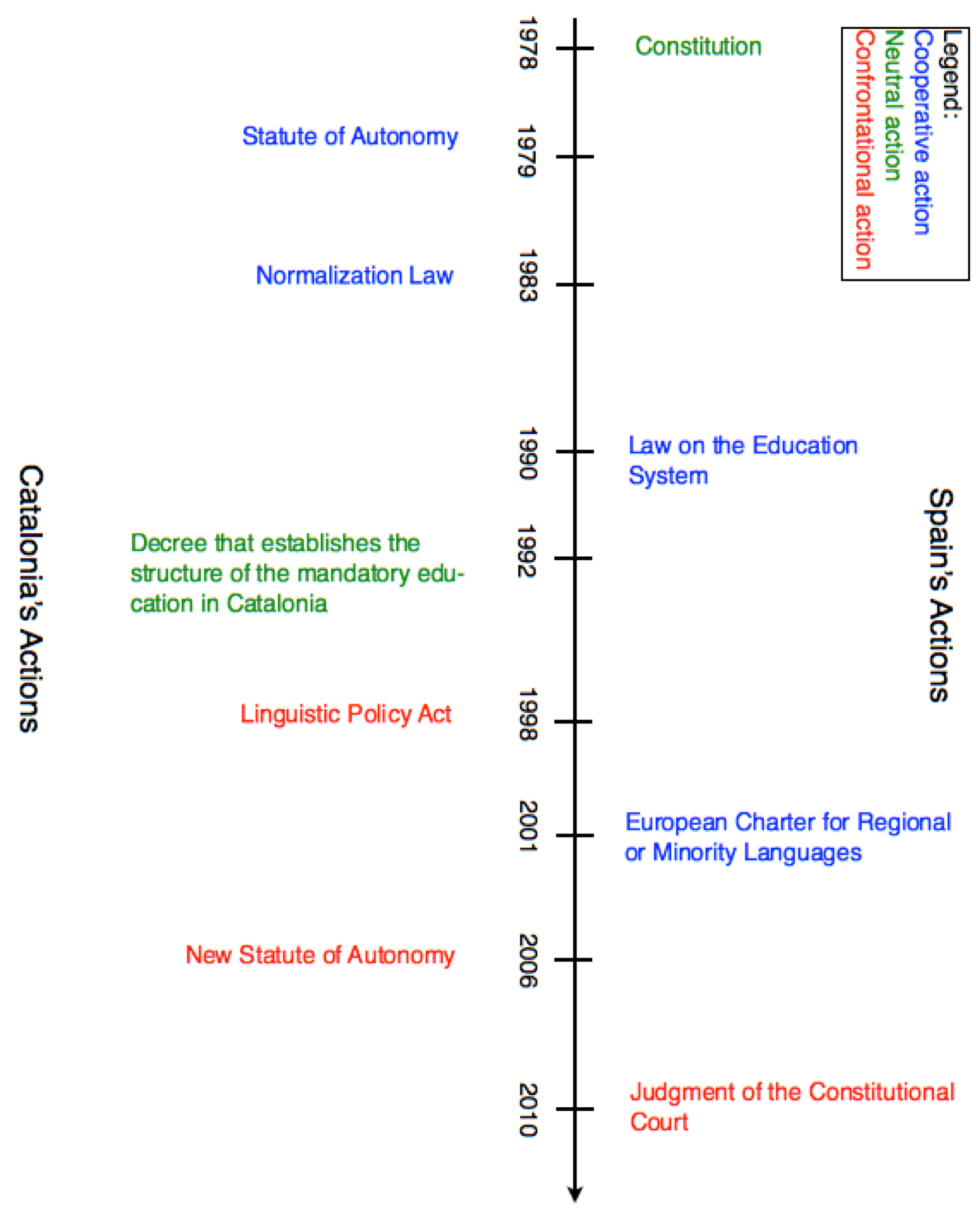
Except for the Spanish Constitution, which stipulates that Spain is a country of one language except in special AC's, both governments displayed cooperative actions until the 1990's. In 1992, the Catalan government started issuing neutral actions that highlighted its uniqueness; the consequences were not drastic. More confrontational actions appeared in that decade and have been rising since then. The 2001 action represents an exception, but it appears that Spain is not complying with all of its articles (as discussed earlier). The latest Constitutional Court's judgment put a serious limit to the ambitions of the Catalan government, notably in terms of linguistic policy.

Interviewee Lluís Jou, Director General of the Linguistic Policy of Catalonia from 1996 to 2003, claimed that Madrid has grown increasingly belligerent as the Catalan language has asserted its presence in Catalonia. According to him, the Generalitat does not trust Madrid regarding linguistic policy and contacts between civil servants of the two governments are scarce. Catalonia does not want to discuss linguistic policy with Madrid - for example, within a bilateral commission on linguistic policy - because Catalonia thinks that Madrid would promote Castilian over Catalan. When Jou was in charge of designing the 1998 Linguistic Policy Act, Madrid was very vigilant of Castilian and was afraid of its potential regression (Interview with Lluís Jou 2012). This view was confirmed by an interview at the Embassy of Spain in Ottawa with Ignacio Sánchez de Lerín García-Ovies, Deputy Head of Mission. He claimed that AC's are keen on wasting money on bilingualism and others because it promotes their image to their citizens. According to him, in Spain, there is a general consensus that bilingualism is a waste of money (Interview with Ignacio Sánchez de Lerín García-Ovies 2012). 


\subsection{Conclusion}

The linguistic policies in Québec-Canada and in Catalonia-Spain have much in common. In both cases, the minority nation promotes a national identity based on the minority language (respectively French and Catalan) through public policies, which mainly consist of education laws (and immigration laws in Québec, but not in Catalonia although the 2006 Statute had plans for it). In both cases, the central government agrees to the promotion of the minority language in the minority nation, but to a certain degree. It projects itself a national identity that is not based on the recognition of linguistic minorities, but rather on the right of individuals to use the central state's majority language in the minority nation.

The difference between Québec-Canada and Catalonia-Spain lies in the responses, the retaliation that occurs. In the former case, the competition was more fierce. The number of actions is higher than in the latter case, and more actions tend toward the confrontational pole of the continuum. Also, Catalonia and Spain seemed more aligned until the late 1990's, when Catalonia started enacting a stricter linguistic policy. The situation between Québec and Canada appears more cooperative since the late 1990's, when both governments reduced the confrontation of their actions in linguistic policy.

Why did these dynamics differ? The answer seems to lie in the incremental character of the minority nation's demands. First, in Spain very few - and definitely not political elites - supported the dictatorship of Franco after his death. ${ }^{32}$ The prohibition of minority languages across Spain under his reign epitomized the oppression endured by all

32 Until 2006, supporters of Franquismo, or Franco's nostalgics, would gather to commemorate his death on November 20 at the Valle de los Caídos. Since 2007, the Ley de Memoria Histórica has prohibited, among other things, this celebration. 
Spaniards. Thus, Spain and Spaniards were in favor of more rights and promotion of minority languages. Second, no one forecasted that Catalonia would later bring other political demands, or even broader recognition to the table. Third, other minorities within Spain (the Basque Country and, to a lesser degree, Galicia) also wanted more recognition, adding support to Catalonia. Fourth, Catalonia (and the Basque Country) was relatively rich and Madrid needed its support. The majority nation's attitude towards Québec's demands was different in Canada. First, in the 1960's, Québec was becoming increasingly nationalist and it was clear that independentist ideas were in the air. The relatively sudden uproar of Québec seemed to come out of nowhere. Second, no other group within Canada supported Québec. Francophones outside of Québec perceived Québec's will as dangerous for their own survival after the Quiet Revolution (Harvey 1995) - left alone in Canada if Québec were to separate, what would they become? Third, Québec was relatively poor - and Duplessis, during his long reign, had not developed great connections with the federal government, focusing mainly on an autonomist Québec (Durocher 1969, 25,27; Laporte 1960, 139).

The depiction of the competition over linguistic policy in Québec-Canada and Catalonia-Spain comports with the model presented in the previous chapter. These minority nations and majority nations compete for the loyalty of their citizens via linguistic policy. First, when it comes to minority nations, Catalonia aims at a concordance between its linguistic policy and its mainly Catalan population. Since the end of Franco's dictatorship, the Catalan government's linguistic policy increasingly promotes the Catalan language. In Québec, from the 1960's to the 1990's, the government 
has increasingly tried to promote the French language. This is arguably less fervent since the 2000's, but the government wants French to remains its chasse gardée. Second, as for majority nations, Spain was, after Franco and when the Catalan language was feeble, indulgent towards Catalan demands. Since the mid-1990's, Catalonia and the Catalan language appear arguably stronger and Madrid has started to fear interference with the upkeep and predominance of Castilian in Catalonia. Canada, confronted by a province that wanted to be uniquely French, envisioned a threat to its territorial unity and responded with a bilingual policy across the country. In both cases, the origin of the confrontation is the same: the minority nation does not count on the majority nation's government for protection, and the minority nation's government has ample room to articulate this to its citizens.

Thus ensues a competition in which both governments present linguistic policies that match as closely as possible the identity of their citizens. At that game, the minority nation comes the closest to representing its citizens, as their identity is more cohesive than that of the country as a whole. 


\section{Competition through foreign policy}

This chapter describes the competition in Québec-Canada and in Catalonia-Spain, in light of the model presented earlier, for the specific field of foreign policy.

Foreign relations, and the policy that governs it, are of vital importance for minority nations (Garcia Segura 2008; Lecours 2002). Three main factors explain why Québec and Catalonia - along with the federated states of Belgium - are the most active federated states with regard to international relations: a) they seek international support for their nationalistic cause; b) they want to pursue nation-building, that is, to promote the minority nation to its inhabitants; and c) they want to foster economic development $(\mathrm{N}$. Michaud 2006, 264; Paquin 2008, 71).

The foreign policies of Québec-Canada and Catalonia-Spain display less confrontation than the linguistic policies, studied in the previous chapter. Québec and Ottawa settled on the matter in the 2000's. In Catalonia and Spain, from the 1990's to the mid-2000's, little confrontation occurred and it became confrontational after Catalonia's revised Statute of Autonomy in 2006. In the case of Québec, France acted as a catalyst in increasing the powers of the minority nation in foreign policy; the EU did not play the same role for Catalonia.

What lies beneath these apparent situations? How do the minority and majority nation's governments deal with each other when it comes to foreign policy? How have the competitive dynamics played out since the 1960's in Québec-Canada and the 1970's in Catalonia-Spain?

The rest of this chapter is divided into two parts, following the respective cases 
studied. It begins by describing the foreign policies of Québec and Canada since the 1960 's, the period that corresponds to the rise of the nationalistic movement. Then, it describes the foreign policy of Catalonia and that of Spain since the late 1970's, commencing with the end of Franco's dictatorship. Finally, it presents the results in a continuum summarizing the events for each case.

\subsection{Foreign policies in Québec and in Canada}

From the 1960's to this day, the foreign policies of Québec and Canada have swayed from cooperation to confrontation with a clear predominance of the latter category.

\subsubsection{Before the 1960's}

The 1867 BNA Act stipulates that the federal government has jurisdiction over foreign policy: "The Parliament and Government of Canada shall have all Powers necessary or proper for performing the Obligations of Canada or of any Province thereof, as Part of the British Empire, towards Foreign Countries, arising under Treaties between the Empire and such Foreign Countries" (United Kingdom 1867, art.132). Since the Statute of Westminster in 1931, Canada has the right to conclude its own treaties, but nothing stipulates that Ottawa can force the application of international treaties. Nevertheless, the federal government initially tried to impose treaties on provinces, and many cases were brought to court. These cases have shaped the current understanding of jurisdiction.

Three judgments by the Judicial Committee of the Privy Council in London (which was Canada's last tribunal until 1949) are of interest in assessing the foreign affairs' jurisdiction of each level of government in Canada (Lecours 2009). The 1932 
judgment on the Regulation and Control of Aeronautics in Canada stipulated that, in the case of conflicting jurisdiction (that is, between sections 91 and 92 of the BNA Act), the federal government was to have paramount authority over the provinces (Russell 1982, 103). The Privy Council decided that section 132 of the BNA Act was to prevail in international agreements: "They [the judges] consider the governing section to be s. 132, which gives to the Parliament and Government of Canada all powers necessary or proper for performing the obligations towards foreign countries arising under treaties between the Empire and such foreign countries" (Russell 1982, 105). Also in 1932, the judgment by the Privy Council on Regulation and Control of Radio Communication in Canada followed the same line:

"Being, therefore, not mentioned explicitly in either s. 91 or s. 92, such legislation [on radio communication] falls within the general words at the opening of s. 91 which assign to the Government of the Dominion the power to make laws 'for peace, order and good government of Canada in relation to all matters not coming within the classes of subjects by this Act assigned exclusively to the legislatures of the Provinces' " (Russell 1982, 110).

The Privy Council made a volte-face in 1937. Contrary to both decisions in 1932, which granted international power to the federal government, the Privy Council ruled in the Labour Conventions Case that "If the [international] treaty dealt with a subject that was normally under section 92 [which defines provinces' powers], then legislation giving effect to it could only be enacted by the provincial legislatures" (Russell 1982, 122). In other words, "this means that Canada cannot become a party to an international agreement which requires legislative action beyond the ambit of section 91 unless the prior approval of the provinces is first secured" (Russell 1982, 123). The idea behind the judgment was that, if the federal government could not implement legislation in domestic 
issues that belonged to section 92 , then it would be unreasonable to allow it to secure this legislation merely by signing an international treaty dealing with a paragraph of section 92 (Russell 1982, 129). This judgment is employed by Québec (and other provinces) as the justification of their role in international treaty implementation - in fact, it is the premise of the Gérin-Lajoie doctrine (Lecours 2009).

The teaching of the 1937 judgment on Labour Conventions Case is that, in Canada, a treaty, in order to be applied, must be incorporated by a law emanating from the concerned level of government (determined by articles 91 and 92 of the 1867 BNA $A c t)$. The consequences of the jurisprudence were apparent in the Draft Declaration of the United Nations in 1948. Lester B. Pearson, then Prime Minister of Canada, pronounced a discourse before the general assembly in which he stressed that Canada could not express itself in some committees that had to do with provincial matters (Paquin 2006c, 36-7). A more recent example is that only Québec, Alberta, Manitoba, and Prince Edward Island have ratified the agreement on labour included in the North American Free Trade Agreement (NAFTA) - labour being a provincial jurisdiction (Nossal, Roussel, and Paquin 2007, 496).

Given this legal precedent, the federal government has always been careful not to spur contestation regarding its international affairs. Consequently, the federal government has ratified fewer international treaties than unitarian countries (Dehousse 1991, 181). Another strategy employed by the federal government is to ratify an international treaty, but including in its final version a Canada clause which stipulates that the federal government can only respect the treaty in the limits of its own jurisdiction and that its 
application is subject to the constitutional rights of the provinces. The federal government first used a federal clause in an international treaty in 1961 with the International Labour Organization (Paquin 2006c, 38).

This federal clause nowadays has two variations. First, some treaties are applied to only a few provinces (e.g., the Hague Conference on Private International Law of 1968 and the Convention providing a Uniform Law on the Form of an International Will of 1973). Second, there may be a clause that obligates signing countries to take "all reasonable measures" (as in art. XXIV:12 of the General Agreement on Tariffs and Trade (GATT) of 1947) or "all necessary measures" (as in art. 105 of the NAFTA of 1992) in order to ensure compliance of the treaty by provinces (de Boer 2002,3). Nevertheless, neither the GATT nor NAFTA can "adequately address measures that fall outside federal competence" (Hayes 2005, 621). Put otherwise, when the federal government signs an international treaty, it cannot promise compliance by the provinces.

\subsubsection{After the 1960's}

Three reasons explain the development of Québec's international relations in the 1960's. First, the Quiet Revolution (discussed in a previous chapter) instigated a large enterprise of nation-building. Québec found support for its project in France: Québec was more welcome there than in the United Kingdom or in the U.S.A, and it could reinforce the status of the French language with the help of France. Moreover, Québec already had a relationship with France. Paris was the first city (in 1882) where Québec had appointed an agent-general. His mandate was to "act as "the accredited representative of the government of Quebec for all negotiations falling within the jurisdiction of the province' 
" (Ministère des Relations internationales du Québec 2006, 3) $\cdot{ }^{33}$ France was also the first place where Québec had opened a Maison du Québec or Québec Government Office (in 1961) (Ministère des Relations internationales du Québec 2006, 3). Further, President De Gaulle catalyzed Québec's relations with France (Bernier 1996, 2001, 134-136).

Second, in the 1960's, Québec was in a phase of internationalization and did not want to allow the federal government to act unilaterally in its jurisdiction on the international scene. Francophones were underrepresented in the federal civil service, Ottawa was disinterested in Francophonie matters, and there was little knowledge of Québec's political issues outside the province (Bernier 1996, chap.4). Québec thus understood that it was the only entity in Canada that could reasonably carry out relations with other Francophone nations.

Third, in the 1960's, parallel to a strong enterprise of nation-building, Québec wished to gain external recognition. Indeed, the privilege of meeting with heads of state is a very powerful symbol as it is usually restricted to country heads. In 1961, Québec enacted a law on foreign agents and delegates, announcing an expansion of its offices abroad (Ministère des Relations internationales du Québec 2006, 4). For the Québec government, international relations had the potential of strengthening the sentiment of identity within Québec itself (Nossal, Roussel, and Paquin 2007, 565-70).

\subsubsection{Education Agreements with France (1965)}

The beginning of the tension between Québec and Ottawa occurred in 1965 when Québec signed agreements with another country, France, without the involvement of Ottawa. In

33 Québec had also appointed agents-generals in London (1911), in Brussels (1914), and New York (in 1943) (Ministère des Relations internationales du Québec 2006, 3). 
February of 1965, Québec signed an agreement with France on a program of exchanges related to education. A few months later, in November of 1965, both signed another agreement on cultural exchanges. In order to implement these two agreements, a Commission interministérielle des relations extérieures du Québec - composed of French and Québécois representatives - was created (Ministère des affaires fédéralesprovinciales du Québec 1966, 12-13).

In short, France helped Québec have a presence at international conferences, against Ottawa's will. These two events led to a series of conflicts between Québec and the federal government, over the international engagement of Québec. Given the historical significance that these agreements would have, it is interesting to note the perception of students of Québec's foreign policy, that Québec would not have carried such a relationship with France without the latter's influence:

"S'il y a eu au Québec un désir de poursuivre sur le plan international la modernisation entamée au début des années 1960, il est douteux que le Québec, occupé ailleurs, eût autant oeuvré dans ce domaine sans les pressions françaises. Les pressions françaises forcèrent une réaction alors que les ressources à Québec étaient limitées, ce qui a souvent forcé certaines improvisations avant que le Québec ait développé ses capacités étatiques. C'est, par exemple, du gouvernement français que vient l'idée de la coopération en éducation" (Bernier 1996, 5).

Bernier argues that De Gaulle (who shouted the famous "Vive le Québec libre !" in 1967) and his followers used Québec to distinguish France from the U.S.A., the United Kingdom, and Canada $(1996,6)$.

\subsubsection{Gérin-Lajoie Doctrine (1965)}

These two agreements between Québec and France were just the beginning of a tense 
relationship between Québec and Ottawa with regard to foreign relations. Québec was seeking, concomitant with the Quiet Revolution, to widen the influence of its government - and when it came to international relations, Québec was not satisfied with the federal government. A double complaint emerged: Québec was not well represented by the federal government on the international scene and the federal government's External Affairs did not care sufficiently about Francophone states (Bernier 1996, 50).

"Paul Gérin-Lajoie, le Vice-premier ministre et Ministre de l'Éducation du Québec en 1965, mettra en avant des arguments nationalistes afin de justifier que le Québec développe sa propre politique internationale car, selon lui, ce dernier n'est pas assez bien représenté par le gouvernement fédéral et parce que les services extérieurs canadiens négligent les États francophones" (Paquin 2008, 74).

On April 12 of 1965, Paul Gérin-Lajoie, then Deputy Premier (Vice-Premier ministre) and minister of Education of Québec, pronounced a discourse before the Consular Corps List of Montréal. This speech stipulated what is now called the GérinLajoie doctrine. In essence, it claims that Québec can negotiate and apply international agreements in its fields of jurisdiction (N. Michaud 2006, 268).

"J'ai mentionné, il y a un instant, la surprise qu'a causée la signature, par la France et le Québec, d'une entente sur l'éducation. Cette entente est tout à fait conforme à l'ordre constitutionnel établi. Face au droit international, en effet, le gouvernement fédéral canadien se trouve dans une position unique. S'il possède le droit incontestable de traiter avec les puissances étrangères, la mise en œuvre des accords qu'il pourrait conclure sur des matières de juridiction provinciale échappe à sa compétence législative. Ainsi en a décidé, il y a près de trente ans [en 1937], un jugement du comité judiciaire du Conseil privé, jugement qui n'a jamais été infirmé” (Gérin-Lajoie 1965).

Gérin-Lajoie reminded his audience that the agreements signed between Québec and France were consistent with the judgment of 1937 of the Judicial Committee of the Privy Council. What is more, Gérin-Lajoie said that, since the provinces - not the federal 
government - were in charge of implementing international treaties, they should also be entitled to negotiate these treaties when they affected their jurisdictions:

"Il n'y a, je le répète, aucune raison que le droit d'appliquer une convention internationale soit dissocié du droit de conclure cette convention. Il s'agit des deux étapes essentielles d'une opération unique. Il n'est plus admissible non plus que l'État fédéral puisse exercer une sorte de surveillance et de contrôle d'opportunité sur les relations internationales du Québec" (Gérin-Lajoie 1965).

\subsubsection{Conference of the Ministers of Education of French African Countries in Gabon (1968) and General Conference of the Francophonie in Paris (1968)}

France and Québec strengthened their relationship, using their common language as a justification for, literally, circumventing Ottawa on two occasions in 1968.

In 1967, it became apparent that Québec could be invited to both the Conference of the Ministers of Education of French African Countries in Gabon and General Conference of the Francophonie in Paris - without the supervision of Canada. Prime Minister Pearson wrote in December of 1967 to the Premier of Québec, Johnson, to suggest that: a) when a meeting would cover general matters, the Secretary of State for External Affairs would preside the Canadian delegation; and b) when a meeting would have to do exclusively with education, the minister of Education of Québec would be part of the Canadian delegation, perhaps presiding it. No answer came from Québec (Sharp 1968, 33-35).

Since education is of provincial jurisdiction, Québec judged that it should participate to the 1967 event - without federal supervision. It asked France to intervene; Ottawa asked the opposite. In the end, France talked Gabon into inviting Québec and not 
Ottawa. Québec attended the Conference of the Ministers of Education of French African Countries in Libreville, Gabon, from February 5 to 10 of 1968, but not Canada (Sharp 1968, 35). Québec's representatives were treated with the highest regards and Ottawa suspended all diplomatic relations with Gabon.

Then, on March 8 of 1968, Pearson wrote again to the Premier of Québec. He highlighted the fact that other Francophones lived in Canada and insisted that the country should remain united - but, once more, received no answer from Québec. On April 5 of the same year, Pearson wrote another letter to Premier Johnson. He did receive a response this time, one day before the public announcement that Québec would participate in the General Conference of the Francophonie in Paris, to be held from April 22 to 26. Apparently, "[the] Canadian Government was never officially informed of the status of the Québec delegation at the Paris meeting. [...] the Québec minister stated after the conference that Québec had participated on the same basis as other delegations" (Sharp 1968, 38).

\subsubsection{Federalism and International Relations (1968)}

Confronted with a growing relationship between Québec and France - one that did not include Ottawa - the federal government had to intervene. Later in 1968, Paul Martin, the federal government's Secretary of the State for External Affairs, released a White Book titled "Federalism and International Relations." The federal government was trying to deal with the growing international presence of Québec. Indeed, in the preface by Prime Minister Pearson, one reads that: "An additional special factor [to the new attention directed to Canada's external relations] has been the new interest of French-speaking 
Canadians in closer contacts with the French-speaking community in the world" (Martin $1968,5)$.

In essence, this document claimed that international relations were the central government's jurisdiction solely. The rationale was double. First, when Canada was a colony, the Queen had all powers in external affairs (according to paragraph 132 the $B N A$ $A c t$ ). Once Canada was no longer a colony, all powers assumed by the Queen were transferred to the Governor General. Thus, "it is reasonable to conclude that the powers required by an independent state in fact reside in that state, and further, when Canada achieved autonomy, only one entity became independent and was recognized as such by the international community" (Martin 1968, 14). Second, it would make no sense for the provinces to enact laws related to external affairs since "the Federal Executive is empowered to disallow acts passed by provincial legislatures whether or not such acts deal with matters within the legislative competence of the provinces" (Martin 1968, 15).

Also in 1968, but under a different Secretary of the State for External Affairs, this time Mitchell Sharp, the federal government published "Federalism and International Conferences on Education." The reason for the publication of this supplement is similar to the one behind the earlier publication, namely, the participation of Québec to the conferences on education of Francophone ministers in Libreville, Gabon, and then in Paris, France (Sharp 1968, 4). It is centered once more on the statement that Canadian foreign policy and foreign relations cannot be divided (Sharp 1968, 8). It argues against Québec's doctrine, Gérin-Lajoie, in which the 1937 Privy Council's judgment allowed for provinces to carry their jurisdictions abroad (Sharp 1968, 9-10). 


\subsubsection{Agence de coopération culturelle et technique (1970)}

The response of the federal government did not stop the Québec government and France from pursuing their relationship. In 1970, African countries and France created the Agence de coopération culturelle et technique (ACCT) - which later became the Organisation internationale de la Francophonie - in order to "promouvoir et [diffuser] les cultures des Hautes Parties contactantes et [intensifier] la coopération culturelle et technique entre elles" (Agence de coopération culturelle et technique (ACCT) 1970, art.1). Two conferences in Niamey, Niger, took place to create the ACCT. Both times, France used all of its influence over African countries and succeeded, against Ottawa's will, in getting Québec a distinct invitation (Paquin 2006a).

Moreover, France made sure that Québec obtained a seat at the ACCT (Bernier 1996, 49; 2001, 136). Louis Balthazar claims that "en dépit de la prétention du gouvernement du Canada, le Québec s'est vu octroyer un véritable statut international" $(2005,180)$. Article 10 of the Charter of the contemporary Organisation internationale de la Francophonie (OIF) - which reproduces article 3.3 of the Convention of the former ACCT - reads:

"Dans le plein respect de la souveraineté et de la compétence internationale des États membres, tout gouvernement peut être admis comme gouvernement participant aux institutions, aux activités et aux programmes de l'OIF, sous réserve de l'approbation de l'État membre dont relève le territoire sur lequel le gouvernement participant concerné exerce son autorité, et selon les modalités convenues entre ce gouvernement et celui de l'État membre" (Organisation internationale de la Francophonie 2005, art.10).

Prime Minister Pierre Trudeau (1968-79 and 1980-4) tried to impose a solely Canadian presence at the ACCT, but the French and Québec civil servants were able to 
negotiate a singular and official Québec presence, within the Canadian delegation (Paquin 2006b, 37-40). Yet, Balthazar dismisses the impact of a special seat for Québec:

"Le statut international du Québec demeure donc bien encadré par l'État membre canadien et ne peut être opérationnel sans un minimum de concertation entre les gouvernements d'Ottawa et de Québec. En dépit de moult accrochages entre les deux instances, cette concertation s'est imposée le plus souvent au gré des rencontres internationales et des politiques québécoises dont les objectifs sont très rarement différents de ceux du gouvernement canadien" (Balthazar 2005, 180).

In 1971, Québec and Ottawa signed a protocol (titled "Modalités selon lesquelles le gouvernement du Québec est admis comme gouvernement participant aux institutions, aux activités et aux programmes de l'Agence de coopération culturelle et technique") that confirmed the place of the former in the ACCT, in agreement with the Convention of the ACCT (Ministère des Relations internationales du Québec 2006; Morin, Rigaldies, and Turp 1988, 375-382).

\subsubsection{Conférence des chefs d'État et de gouvernement des pays ayant en commun l'usage du français (1985)}

When the separatist PQ was elected in 1976, the relationship between Québec and Ottawa was tense and became macro-confrontational around the 1980 referendum. The Québec government sought as many contacts as possible in order to increase its international presence, mainly at the ACCT. The ACCT wanted to meet regularly and formally. Prime Minister Trudeau lobbied that Québec would not participate in the meetings, but France, every time, threatened to withdraw if Québec were to be excluded from the meetings. In the end, President Mitterand of France (1981-95) agreed to wait before organizing the first summit of the Francophonie (Paquin and Beaudoin 2006). 
In 1984, Prime Minister Brian Mulroney (1984-93) was elected. He sought to deal with Canada's constitutional problems, making Québec adhere to the 1982 Constitution "with honour and enthusiasm." As for the foreign policy of Québec, he claimed that he saw nothing wrong in the direct and privileged relationship between France and Québec (Paquin and Beaudoin 2006, 148). A compromise was reached under the simultaneous office terms of Prime Minister Mulroney and Premier Pierre-Marc Johnson (1985): both signed the "Entente entre le gouvernement du Québec et le gouvernement du Canada relative au Sommet francophone" (Gouvernement du Canada and Gouvernement du Québec 1985; Morin, Rigaldies, and Turp 1988, 380-381). It was agreed that for matters related to the world political situation, Québec's Premier would be present and show interest, while for matters related to the world economic situation, Québec's Premier could - after consultation with the Prime Minister of Canada - intervene in the matters that are of interest to Québec. The Québec government would attend the entire summit and be identified as "Québec-Canada." In practice, Québec participates as a full member (Paquin and Beaudoin 2006, 149). The first summit took place in 1986.

\subsubsection{Canada in the World (1995)}

In another instance of macro-confrontation (centered on the referendum of 1995), the federal government released a statement on foreign policy titled "Canada in the World." The Québec government heavily criticized this statement. Balthazar (2005) identifies two elements that irritated the Québec government: a) provinces are not mentioned as a level of government; and b) the system of education is referred to as a unified Canadian one even though education is of provincial jurisdiction according to the 1867 BNA Act. 
The bulk of the discontent came from one of the objectives of the statement. The three objectives of this foreign policy statement are: "The promotion of prosperity and employment; The protection of [Canada's] security, within a stable global framework; and The projection of Canadian values and culture" (Government of Canada 1995, 3). The Québec government disliked the third objective.

The federal statement designates "Cultural affairs [as] one of the pillars of [Canadian] foreign policy" (Government of Canada 1995, 38). Moreover, it insinuates that there is only one Canadian culture:

"in the medium- and long-term, a country that does not project a clearly defined image of what it is and what it represents, is doomed to anonymity on the international scene. Only Canadian culture can express the uniqueness of our country, which is bilingual, multicultural, and deeply influenced by its Aboriginal roots, the North, the oceans, and its own vastness" (Government of Canada 1995, 37).

\subsubsection{Response of the Québec government (1999 to 2002)}

In response to "Canada in the World" and still within the macro-confrontation climate following the 1995 referendum, the Québec government first published a declaration on the imperative of its participation in international forums on issues related to education, culture, and language (the "Déclaration du gouvernement du Québec concernant la participation aux forums internationaux traitant d'éducation, de langue, de culture et d'identité") in 1999. As part of the rationale for this statement, the document reads that:

"Considérant que, dans son énoncé de 1995, Le Canada dans le monde, faisant de la culture un des trois piliers de son action internationale, le gouvernement Canada ignore jusqu'à l'existence de la culture québécoise et que des ministres fédéraux la décrivent comme une simple " composante régionale » d'une culture canadienne unique" (Gouvernement du Québec 1999). 
Clearly, the Québec government's declaration aimed to balance the federal government's 1995 "Canada in the World." More actions would follow on the part of the Québec government, consisting of two laws, in 2000 and 2002.

Notably, Québec enacted the Act respecting the exercise of the fundamental rights and prerogatives of the Québec people and the Québec State (also referred to as Bill 99) in the year 2000. Louis Bélanger argued that it is "the current government's response to the Federal 'clarity bill' " $(2002,199-200)$, which constitutes another element of the macro-confrontation that reigned between Québec and Ottawa.

Bélanger (2002) claims that the Gérin-Lajoie doctrine is stipulated in Chapter II of the act, which maintains that no international treaty that affects provincial jurisdictions can be imposed on Québec against its will and that it is free to defend these on the international scene:

"The Québec State is free to consent to be bound by any treaty, convention or international agreement in matters under its constitutional jurisdiction. No treaty, convention or agreement in the areas under its jurisdiction may be binding on the Québec State unless the consent of the Québec State to be bound has been formally expressed by the National Assembly or the Government, subject to the applicable legislative provisions. The Québec State may, in the areas under its jurisdiction, establish and maintain relations with foreign States and international organizations and ensure its representation outside Québec" (Québec 2000, chap. II, par.7).

This action illustrates the competition that takes place between the foreign policies of Québec and Canada. Louis Bélanger (2002) even concludes that the Canadian response to Québec's international action after Trudeau's centralist and provincial equality principles is largely responsible for Québec's extensive foreign policy $(2002,208)$.

The 2000 act became more tangible with Québec's Act to amend the Act 
respecting the Ministère des Relations internationales and other legislative provisions (also known as Bill 52) in 2002, according to which all international agreements related to provincial jurisdiction must be voted by its Parliament. Since then, every international agreement signed by the federal government that affects the jurisdictions of Québec must by approved by a vote in Québec's National Assembly:

"This bill establishes a mechanism enabling the National Assembly to approve any important international commitment the Government intends to make either in respect of a Québec international agreement or an international accord pertaining to a matter within the constitutional jurisdiction of Québec" (Québec 2002, Explanatory notes).

This novelty brought about by the 2002 law - that is, the process of approval by Québec

- usually has two steps. First, the minister of Relations internationales of Québec gives his agreement. Second, the Government of Québec does so (Turp 2006b, 60).

In 2005, the Québec government released a list of demands regarding its presence in international forums:

"Québec must be a full member of Canadian delegations and must be free to appoint its own representatives to such delegations.

Québec must have access to all information and must be involved in helping plan the Canadian position prior to any negotiations.

Québec must have the right to speak for itself at international conferences and organizations.

Québec's right to consent before Canada signs or declares that it is bound by a treaty or agreement must be recognized.

Québec must have the right to present its position at appearances by Canada before the arbitration bodies of international organizations when Québec or its interests are affected" (Ministère des Relations internationales du Québec 2005, 8). 


\subsubsection{Agreement concerning UNESCO (2006)}

On May 5, 2006, Prime Minister Stephen Harper and Premier Jean Charest signed the Agreement between the Government of Canada and the Government of Québec concerning the United Nations Educational, Scientific and Cultural Organization (UNESCO). Since then, Québec has had a formal seat in the Canadian Delegation at UNESCO and has been able to intervene at UNESCO proceedings, meetings, and conferences (Ministère des Relations internationales du Québec 2006, 2). More importantly, the agreement grants recognition to Québec as a "minority nation"; indeed, the agreement commences with: "Recognizing that in Canada, the specificity of Québec, based among other things on the use of the French language and a unique culture, leads it to play a special role internationally" (Gouvernement du Québec and Gouvernement du Canada 2006). The agreement also gives Québec immediate access to all UNESCO's documentation - thus allowing Québec to begin influencing Canada's position on future votes early (Ministère des Relations internationales du Québec 2009).

If Canada and Québec were to have divergent positions as to how to vote, Canada's opinion would win, but it would have to formally explain its position to Québec (Gouvernement du Québec and Gouvernement du Canada 2006, par.3.1). The PQ complained that this agreement is tantamount to Québec sacrificing its own power in areas of provincial jurisdiction, that is, education and culture (Turp 2006a).

A Québec civil servant interviewed on the topic of the UNESCO claimed that Québec and Ottawa do not always have the same opinions on all topics discussed, but that they discuss and find an agreement; namely, an inter-ministerial committee Québec- 
Ottawa meets to find a common position to be presented before the UNESCO. Civil servants from both the Québec and federal governments purportedly work together with collegiality. The civil servant interviewed even thinks that the quality of their discussions makes for a Canadian position that is more well-thought, and thus stronger. Thus, the relation of Québec and Ottawa that was "forced" because of the UNESCO agreement has had positive ripple effects in other areas of foreign relations. A new attitude of collegiality now characterizes all contacts between the two governments regarding most foreign relations. That said, the relation of the two governments regarding international trade remains less "formalized" than the one for the Francophonie and the UNESCO agreement (Interview with anonymous civil servant employed at the ministère des Relations internationales du Québec 2012). This claim, that the relation between the two governments is of lesser quality when it comes to international trade, was corroborated by another Québec civil servant working on international trade. According to him, the current negotiation between Canada and the EU is unique in that the federal government engages with the provinces to a greater extent than in other ongoing trade negotiations (e.g., India and Japan) (Interview with Patrick Muzzi 2012). This claim was somewhat confirmed when interviewing a federal civil servant who asserted that, in the case of the negotiation with the EU, provinces are involved because the EU wants to include provincial government procurement within the agreement. ${ }^{34}$ The EU knows that these are of provincial jurisdiction. For all other negotiations regarding international trade, Canada is presented as a single entity with which to negotiate in order to avoid confusing the other side - except in France, Belgium, and Switzerland, where federalism is well34 This is well documented in Malone (2011). 
understood and Québec known. The question of jurisdiction is not really primary; what matter are the commercial interests (Interview with Randle Wilson 2012).

\subsection{Competing visions of foreign policies}

The high point of Québec's foreign policy is the Gérin-Lajoie doctrine. It states that the province is to have sole responsibility for its foreign policy, without the supervision of the central government. Moreover, other provinces - notably Alberta and, to a lesser extent, Ontario - now concur with this view (Lecours 2009).

The high point of Canada's foreign policy is harder to pinpoint - perhaps "Canada in the World" represents it best. It claims that Canada should speak with a single voice on the international scene. Interestingly, France and the wider Francophonie played a very important role in the relationship between Québec and Canada (Bernier 1996; Nossal, Roussel, and Paquin 2007). As is discussed in the next section, this relationship has evolved since the 1960's from one of confrontation to one of cooperation.

\subsubsection{Competition between Québec and Ottawa in foreign policy}

The following table lists the actions related to foreign policy in Québec and Canada since the 1960 's. In the time line, each action is ascribed to one of three categories, in accordance with the definitions presented earlier. 
Illustration 4: Time Line of Actions in Foreign Policy of Québec and Canada

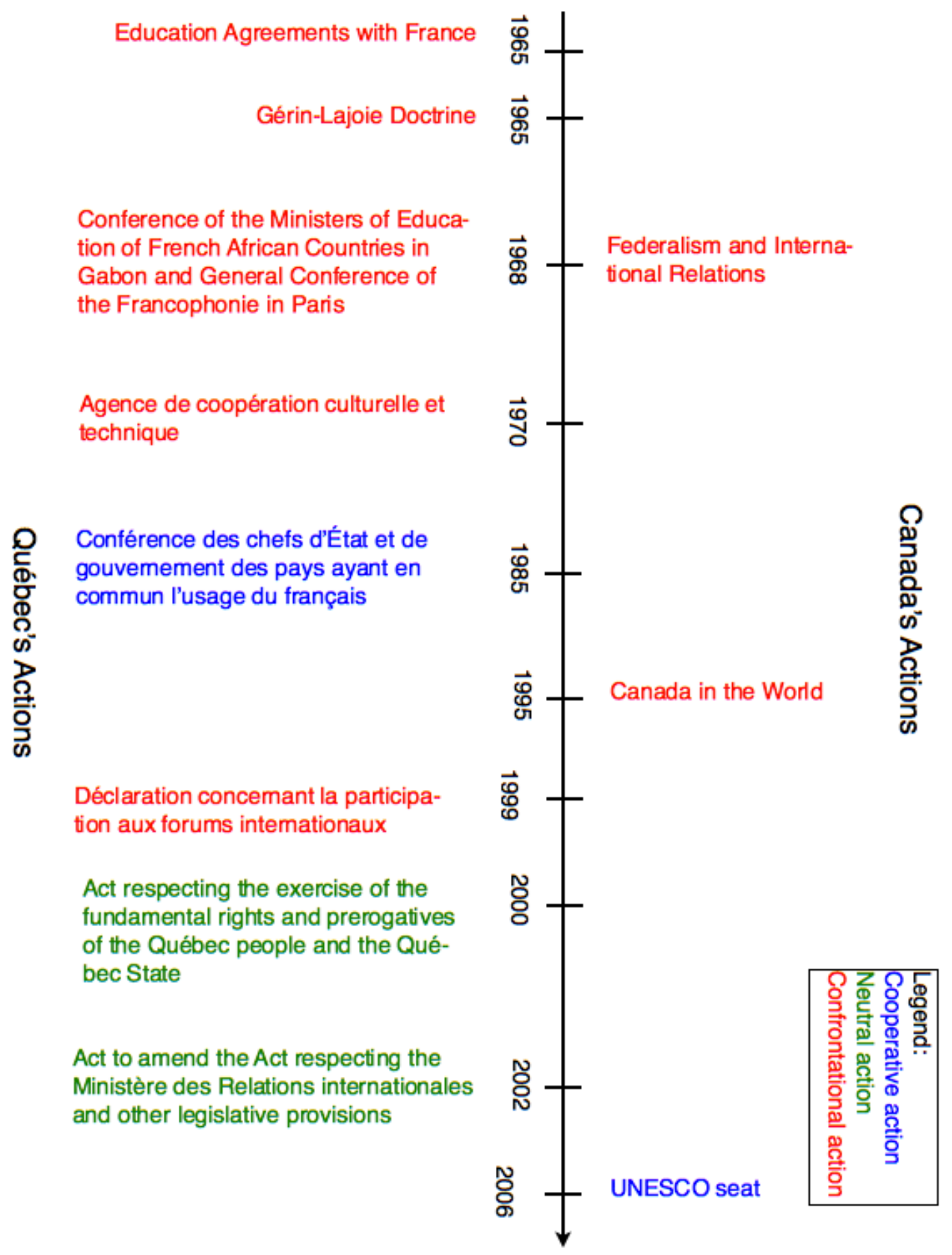


In 1965, Québec's foreign policy actions promoted an identity appropriate for a national minority, thus diverging from Canada's foreign policy at the time. The response of the central government in 1968 opposed Québec's foreign policy - it tried to ensure that the latter would not have its own distinct presence on the international scene. The series of Francophonie events starting in 1968 ensured a series of confrontational actions between Québec and Canada. Nevertheless, in 1985, the foreign policies of Québec and Canada finally reached an agreement as to how they should conduct their foreign policies in a parallel manner, arguably thanks to the cooperative attitude of Prime Minister Mulroney. The rapport between the minority nation and the central government became confrontational again in 1995 with "Canada in the World." Finally, in 2006, when Québec gained a seat at UNESCO, the relationship between Ottawa and Québec seems to have reached a cooperative point.

\subsection{Foreign policies in Catalonia and in Spain}

Since the 1970's, the foreign policies of Catalonia and Spain have significantly departed from their initial period of cooperation, and are now geared towards confrontation.

\subsubsection{Before the 1970's ${ }^{35}$}

Starting in the mid- $18^{\text {th }}$ century, a consensus emerged among some elites in Catalonia on the need to establish its own policies given the transformations occurring in the world. Catalonia adopted industrialization before many areas of the rest of Europe and catalyzed its commerce. King Charles III (1716-1788) opened the ports of the Catalan coast to

35 Most of this section is informed by Casassas et Costa Ruibal (2003). 
Spain's colonies. But the war between Spain and France (1808-1814), the subsequent reign of Ferdinand VII (1813-1833), and the colonial crisis (1811-1830) slowed down the development of a foreign policy.

By the mid- $19^{\text {th }}$ century, political conditions in Catalonia had become favourable to the development of a foreign policy. The renewed Barcelona was revealed when it hosted the Universal Exposition in 1888. Catalan organizations supported other nationalistic movements in Europe, and offered support to Ireland, Crete, and Finland (Casassas and Costa Ruibal 2003, 106). At the beginning of the $20^{\text {th }}$ century, the bourgeoisie - notably the organization Foment del Treball Nacional - of Catalonia decided to find new international markets after the end of Spanish colonization. Catalonia focused mainly on the Americas. Catalans exiled during the Primo de Rivera dictatorship (1923-1930), created associations, and sought support from foreign powers. They even published their own magazine, Quaderns de l'Exili. However, the Second World War (1939-1945) and the subsequent Franco dictatorship (1939-1975) paralyzed further development of Catalonia's affairs.

\subsubsection{After the 1970's}

After Franco's death in 1975, the transition to democracy in Spain commenced. For Catalonia, this meant, in part, the beginning of international relations. According to the academic literature, two things have changed since the late 1970's with regard to foreign relations of Catalonia. First, Spain's membership with the EU facilitated exchanges and promoted the role of the regions (García Segura and Pareja Alcaraz 2003, 116-117). It contributed to lessening the Spanish government's fears of AC's' foreign actions, thus 
reducing the conflictual relation with the Catalan government:

"En général, le processus européen a aidé le déploiement de l'activité extérieure des CA au sens où il a permis de tranquilliser le gouvernement espagnol et de l'aider à changer sa perception: ce qui était vu comme une manifestation protodiplomatique [de confrontation] en Espagne, était admis comme une affaire tout à fait normale en Europe, pour autant que les autres gouvernements européens l'acceptent et que cela ne porte pas atteinte à la cohérence de la politique étrangère de l'État" (Garcia Segura 2008, 148).

As this chapter will show, the reality is more nuanced than the existing literature illustrates.

Second, while Catalonia could have been said to carry out external activity in the 1980 's in order to promote its internal recognition, the objective has been, since the 1990's, mostly economic (Garcia Segura 2008, 159; Paquin 2003, 70-2).

\subsubsection{Constitution (1978)}

Article 149.1.3 of the Spanish Constitution stipulates that the central state has full jurisdiction in international relations: "The State shall have exclusive competence over the following matters: [...] 3. International relations" (Cortes Generales de España 1978 art.149.1.3). Articles 93 and 97 add, respectively, that Madrid has the power to sign international treaties ${ }^{36}$ and to conduct foreign policy. ${ }^{37}$

The interpretation of the Constitution might seem unambiguous - after all, the wording is straightforward. Yet, over the years and as their governments grew, Catalonia and other AC's (notably the Basque Country and Galicia) started questioning its scope.

36 "Mediante la ley orgánica se podrá autorizar la celebración de tratados por los que se atribuya a una organización o institución internacional el ejercicio de competencias derivadas de la Constitución. Corresponde a las Cortes Generales o al Gobierno, según los casos, la garantía del cumplimiento de estos tratados y de las resoluciones emanadas de los organismos internacionales o supranacionales titulares de la cesión" (Cortes Generales de España 1978 art.93).

37 "El Gobierno dirige la política interior y exterior [...]" (Cortes Generales de España 1978, art.97). 
The reason behind this growing questioning is not clear. One possibility was the realization that issues that concerned $\mathrm{AC}^{\prime} \mathrm{s}$ (culture, language) were becoming increasingly dealt with at the international level, hence the need for their direct presence in the international arena. Perhaps these AC's became aware that other minority nations (in particular Québec and Flanders) were active on the international scene in matters under their jurisdictions. The most likely explanation is that, as their governments grew and became increasingly organized (they were not in 1978, after years of dictatorship), these AC's realized that they needed more power than the Constitution stipulated in order to promote their interests. In the 1990's, Catalonia and other AC's were no longer willing to have Madrid manage matters of their jurisdiction internationally.

\subsubsection{Statute of Autonomy (1979)}

In accordance with the dispositions included in the Spanish Constitution, Catalonia enacted its Statute of Autonomy in 1979. The Statute of Autonomy of Catalonia does not include any special mandate for the $\mathrm{AC}$ in terms of foreign policy, except for tourism (Generalitat de Catalunya 1979, art.9.12) and the application of international treaties regarding what affects its jurisdiction (Generalitat de Catalunya 1979, art.27.3). Also, Catalonia can ask Spain to sign international treaties or agreements related to language or culture (Generalitat de Catalunya 1979, art.27.4) and has the right to be informed of other treaties that affected its interests (Generalitat de Catalunya 1979, art.27.5). All other matters that could be deemed related to foreign policy (such as ports and airports) were designated as jurisidictions of Catalonia, but without infringing on the central state's own policy (Generalitat de Catalunya 1979, art.9-28). In sum, Catalonia's Statute of Autonomy 
aligned with the Spanish foreign policy (García Segura and Pareja Alcaraz 2003, 120).

\subsubsection{Judgment 137 of the Constitutional Court (1989)}

In 1985, Spain brought before the Constitutional Court (via the decree 156/1985) what seemed to the central government a conflict of jurisdiction. The Court judged that the Xunta (that is, the government) of Galicia, another historic AC of Spain, was infringing on the Constitution by having signed a "Comunicado de Colaboración" (communiqué on collaboration) with Denmark (Tribunal Constitucional 1989a, II, par.5). However, judge don Eugenio Díaz Eimil wrote a dissenting judgment in which he argued that AC's should be allowed to conduct international activity that is related to their jurisdictions and that does not affect the sovereignty of Spain (Tribunal Constitucional 1989a, Voto). This dissident judgment laid out the foundations of the future of foreign policy for AC's in Spain: "Ce jugement dissident est fondamental puisqu'il est à l'origine d'une conception nouvelle de la politique étrangère des communautés autonomes" (Paquin 2003, 57). It opened a new line of interpretation (García Segura and Pareja Alcaraz 2003, 121). The new perspective it suggested, as to what involvement AC's should be permitted on the international scene, soon became visible in the judgments of the Constitutional Court.

\subsubsection{Judgment 153 of the Constitutional Court (1989)}

In 1985, Catalonia brought before the Constitutional Court the claim that Spain was not respecting its Statute of Autonomy (more specifically, article 9) in a 1984 decree which stipulated that Spain would be solely in charge of determining what constitutes a "Spanish" movie made in "coproduction" (that is, a movie made in Spain in collaboration 
with another country). (This designation would, in turn, favour subsidies.) Catalonia argued that the arts were its jurisdiction and that it had full authority to enforce international treaties (article 27.3 of its Statute); Spain countered that it had full power to sign international treaties (according to article 149.1.3 of the Constitution) (Tribunal Constitucional 1989b). The Court judged that the ascription of a nationality to a movie was the jurisdiction of Catalonia, not Spain (Tribunal Constitucional 1989b, Fallo). Moreover, the Court recognized that not all external relations are "international relations" (Tribunal Constitucional 1989b, II, par.9). This was the beginning of a significant change of the Constitutional Court's position regarding Spain's foreign policy (Aldecoa and Cornago 2009, 250). "International relations" as mentioned in article 149.1.3 of the Constitution were to be understood as referring to "hard core" ("nucli dur") actions (Urgell 2003, 22). More specifically, "international relations" constituted "treaties, peace and war, recognition of states, external representation, international responsibility, etc." (Tribunal Constitucional 1989b, II, par.8, author's translation).

Other judgments by the Constitutional Court followed the new direction with respect to Spain's foreign policy, notably judgment 80 in 1993. The Constitutional Court then agreed with Catalonia and the Basque Country that Spain could not execute international treaties in jurisdictions that belonged to AC's (Tribunal Constitucional 1993). The most important was judgment 165 in 1994 and will be discussed later. Meanwhile, Spain signed the Treaty of the EU in 1992.

\subsubsection{Treaty of the European Union (1992)}

Catalonia (as well as the Basque Country) was a strong promoter of the Treaty of the EU 
(Nagel 2011, 180-181; Roller 2004, 87). Catalonia has been pushing for "regionalism," that is, the input of the regions in the EU decision-making process. In particular, the nationalistic party CiU (in power from 1983 to 2003) tried "to shape, rather than follow, the EU's regional agenda" (Crameri 2008, 19). CiU's Jordi Pujol, 1980-2003 President of the Generalitat, held foreign policy as one of his keen interests and has always claimed that his promotion of regionalism in Europe did not harm the central states. Pujol even presided over the Assembly of European Regions from 1992 to 1996, but was disappointed with the powers given to the Committee of the Regions (created in 1994 in accordance with the Treaty of the EU) (Nagel 2011, 180-181). Nevertheless, he left a tradition of involvement in European affairs - within a strict respect of the Constitution (García Segura and Pareja Alcaraz 2003, 128).

Since 1992, the Treaty of the EU has offered the possibility of participation in the negotiation of European policies to the regions. Specifically, the treaty reads that "The Council shall consist of a representative of each Member State at ministerial level, authorized to commit the government of that Member State" (Treaty on European Union 1992, art.146, now art.203). Spain was encouraged to include the AC's in decisions related to Europe.

In 1992, via the Acuerdo de institucionalización de la Conferencia para Asuntos Relacionados con las Comunidades Europeas (literally, the Agreement that Institutionalizes the Conference on Issues Related to the European Communities, whose acronym is CARCE), Spain initiated a series of multilateral conferences in order to promote cooperation with its AC's. ${ }^{38}$ According to Aldecoa and Cornago, this action was 38 This agreement is regulated by the Ley de Régimen Juridico de las Administraciones Públicas y del 
"[departing] from previous practice" $(2009,254)$. The objective was to inform the AC's on European Community matters and to agree on the implementation of European norms (España 1992a).

\subsubsection{Judgment 165 of the Constitutional Court (1994)}

The Treaty of the EU encouraged, on paper, a greater role for regions across Europe (including AC's in Spain). And Spain did indeed take a series of actions in the next years that appeared to change the roles of AC's and the central government vis-à-vis Spanish foreign policy. One step toward an apparent reduction in control by the central government occurred in a judgment by the Constitutional Court in 1994. In 1988, specifically under decree 89/1988, the Spanish government argued before the Constitutional Court that the Basque government was violating article 149.1.3 of the Spanish Constitution by having an office representing the Basque government in Brussels. This office (under the Basque Department of Industry, Innovation, Commerce, and Tourism) had been in activity since 1981, that is, before Spain even signed the Treaty of Adhesion to the European Communities in 1986.

The Constitutional Court announced its judgment (no. 165) in May of 1994. It judged that "international relations" ("relaciones internacionales") were to be distinguished from the "external activities" ("relaciones con relevancia internacional") of the AC's. The former refer to a state subject to international law; the latter have to do with activities related to jurisdictions that belong to the AC's and have an external relevance, without having consequences for the external power of the state (Tribunal Constitucional

Procedimiento Administrativo Común, under article 5 (España 1992b). 
1994, I.Antecedentes, par.5). The reasoning was that, with a circumspection of "international relations," too many actions of the governments would be considered under the jurisdiction of the central government, thus disrupting the constitutional order (Tribunal Constitucional 1994, II.Fundamentos jurídicos, par.5). "International relations" were thus defined as "relations between international subjects and ruled by the International Law" (Tribunal Constitucional 1994, II.Fundamentos jurídicos, par.5, author's translation).

Aldecoa and Cornago $(2009,251)$ comment that all AC's applauded this judgment. It is understood, since then, that AC's:

"are entitled to develop diverse international activities as far as these activities are instrumental for the effective exercise of their own powers, are not invasive of the powers that the Constitution assigns exclusively to the national government, and neither affect the national government's international responsibilities nor create new obligations" (Aldecoa and Cornago 2009, 251).

In other words, $\mathrm{AC}$ 's can henceforth conduct international relations as long as they "do not imply the exercise of the ius contrahendi, do not create immediate and real obligations towards foreign public powers, do not affect the foreign policy of the State, and do not generate responsibility for the State towards foreign powers or international or supranational organizations" (Tribunal Constitucional 1994, II.Fundamentos jurídicos, par.6, author's translation). In other words, the Constitutional Court ruled that the AC's could conduct "external activities," but not "international relations," as these are reserved to the central state. Hence, the Court allowed the participation of AC's in external activities as long as they were within their jurisdiction and that their action did not affect the core of international relations, that is, sovereignty and state responsibility (García 
Segura and Pareja Alcaraz 2003, 122).

\subsubsection{Agreement of CARCE on the participation of the AC's in the European Communities' issues via the sectoral conferences (1994)}

Given the recent judgment (in May of 1994) by the Constitutional Court and the developments regarding the involvement of regions in the EU decision process, Spain seemed geared toward granting more room to AC's in foreign relations. In November of 1994, a new agreement of CARCE (the Acuerdo de la CARCE de 30 de noviembre de 1994 sobre la participación interna de las Comunidades Autónomas en los Asuntos Comunitarios a través de las Conferencias Sectoriales ${ }^{39}$ ) became the turning point in the activities of the organization. While CARCE was before involved in the "descendent" phase of the decisions (that is, it was informed by Madrid of its decisions and had to execute these), the 1994 agreement meant that Catalonia and other AC's would now be part of the "ascendent" phase (that is, of the decision process of Spain in relation to European institutions) (Ministerio de Política Territorial y Administración Pública de España 2010). Nevertheless, in the event that the AC's and the central government were unable to reach a consensus, the latter would decide the position. In other words:

“Si aucune position commune n'est obtenue [après négociation entre les communautés autonomes et le gouvernement central], l'Accord [de 1994] prévoit que l'État « prendra connaissance des arguments exprimés » par les CA, ce qui signifie que l'État bénéficie d'une marge de discrétion totale pour la défense de ses positions" (Castellà Andreu 2005, 199).

\subsubsection{Act that regulates CARCE (1997)}

In 1997, one more document was added to regulate the actions of the central government

39 Available at: http://www.der.uva.es/constitucional/participacion/re100395.html 
and the $\mathrm{AC}$ when dealing with the EU: the Ley 2/1997, de 13 de marzo, por la que se regula la Conferencia para Asuntos relacionados con las Comunidades Europeas ${ }^{40}$ (literally, the Act that regulates CARCE). This 1997 action is significant because of the institutionalization of the process that it entails.

According to the act, CARCE meets at least twice a year and more if a specific number of AC's requests it (Comunidad de Madrid 2004). More importantly, the 1997 act officially regulates CARCE and its functioning, and adds validity to CARCE (because it becomes a law). For the first time, in 1997, AC's were able to participate in the comités of the European Commission (España 1997; Ministerio de Política Territorial y Administración Pública de España 2010).

\subsubsection{Agreement of CARCE on representation on the EU Council of Ministers (2004)}

The apparent involvement of the AC's in the EU decisions did not stop. Rather, on December of 2004, CARCE signed a new agreement that would allow it to participate in four councils of the Council of Ministers of the EU.

Thus, since 2005, CARCE has been divided into four councils, each subdivided into several sectoral conferences. Each of these four councils corresponds to one of the ten sub-councils of the Council of the EU (Comunidad de Madrid 2004). The councils are: a) Employment, Social Policy, Health and Consumer Affairs Council; b) Agriculture and Fisheries Council; c) Environment Council; and d) Education, Youth and Culture (EYC) Council (Aldecoa and Cornago 2009, 255; Comunidad de Madrid 2004;

40 Available at: http://noticias.juridicas.com/base_datos/Admin/12-1997.html 
Ministerio de Administraciones públicas de España 2005). The AC's elect a representative in each of these councils to represent the AC's (who agree to the representation) at the Council of the EU (Comunidad de Madrid 2004).

This participation in the EU seems significant. Indeed, the Council of the EU is: "the main decision-making body of the European Union." It is "made up of the ministers of the Member States" (Council of the European Union 2011). Among other roles, it: "passes laws, usually legislating jointly with the European Parliament" and "defines and implements the EU's common foreign and security policy, based on guidelines set by the European Council" (Council of the European Union 2011). In sum, AC's now seem to have access to the decision-making process of the EU on issues that interest them. Furthermore, the 2004 agreement stipulates the nomination of two councillors to Spain's Permanent Representation to the EU. Specifically, the Consejería para Asuntos Autonómicos de la Representación Permanente de España ante la UE (REPER) (literally, the Ministry dealing with Issues of AC's at Spain's Permanent Representation to the EU) in Brussels has these councillors or officials ("consejeros") who are in charge of informing all AC's and CARCE of all matters related to the EU decisions that might be of interest to them, and must formulate a consensual position of all AC's (Ministerio de Administraciones públicas de España 2005; Ministerio de Política Territorial y Administración Pública de España 2010).

In 2009, CARCE again modified its agreement in order to participate in a fifth Council, the Competitiveness Council (Ministerio de Política Territorial y Administración Pública de España 2010). In 2010, CARCE was renamed the Conferencia para Asuntos 
Relacionados con la Unión Europea (CARUE) (Ministerio de Política Territorial y Administración Pública de España 2010).

According to Aldecoa and Cornago, the absence of rules governing the nomination of the two representatives is criticized - so much so that Basques and Catalans would prefer to pursue bilateral relations with the central government (2009, 255). This was confirmed when interviewing Catalan civil servants in May 2012. The Catalan Secretaria d'Afers Exteriors (literally, the Secretary of External Affairs of Catalonia) said that the CARUE (called the CARCE until 2010) has lately lost influence and deals with minor questions. When all AC's agree on a theme, their position appears as strong before the central government. Nevertheless, the votes at the CARUE are political, that is, its members vote according to their political party. For example, in Spring of 2012, all AC's but two (among which Catalonia) had ministers of the PP, thus they all voted along. In sum, the CARUE remains a "too soft" lobby mechanism for AC's. Madrid takes into account the opinions of the AC's when it matches its own interest (Interview with Débora Miralles Solé 2012).

\subsubsection{Revised Statute of Autonomy (2006)}

Despite the apparently growing powers given to AC's within CARCE, Catalonia wanted to go further. In 2006, Catalonia revised its 1979 Statute of Autonomy and had it approved by referendum (as already discussed in the previous chapter). The new Statute of Autonomy included more power in many spheres for Catalonia - among these were the international relations of the AC. Indeed, Aldecoa and Cornago speak of the "[opening] of a new era" $(2009,251)$, alluding to the ambitious foreign policy that other AC's might 
replicate in their own revised Statute of Autonomy.

The revised Statute of Autonomy of Catalonia planned a bilateral commission between Catalonia and Spain (Generalitat de Catalunya 2006, art.183) in which the former would contribute to the position of the latter on European matters of Catalonia's jurisdiction (Generalitat de Catalunya 2006, art.184-192). Much like the CARUE, that is, the bilateral commission for EU matters, this mechanism does not enhance Catalonia's influence on Spain's foreign policy decisions in reality. The Subcomisión sobre la UE (literally, the Sub-commission on the EU) is part of the Comisión bilateral para el desarrollo del Estatuto de autonomía (literally, the Bilateral Commission for the development of the Statute of Autonomy). As of Summer of 2012, the Sub-commission had not met since the election of the PP in the Summer of 2011 (Interview with Débora Miralles Solé 2012). The revised Statute of Autonomy also planned that Catalonia would now conduct international relations (“acció exterior") (Generalitat de Catalunya 2006 art.193-200). Specifically, Catalonia would be able to request that Spain sign international treaties that have to do with Catalonia's jurisdictions (Generalitat de Catalunya 2006, art.196). In addition, the AC would participate in international bodies that affect its jurisdiction, in particular UNESCO (Generalitat de Catalunya 2006, art.198).

\subsubsection{Judgment of the Constitutional Court (2010)}

While the central government had - apparently - increasingly allowed the AC's to conduct their respective foreign policies, especially since the 1992 Treaty of the EU, the judgment on the revised Catalan Statute of Autonomy by the Constitutional Court in 2010 
(already discussed in the previous chapter) put a halt to this seemingly expanding cooperation. Spain's foreign policy stance was hardened: the Constitutional Court clearly set out that Spain's jurisdictions could not be diminished by the existence of any bilateral bodies with its AC's.

In this judgment, two elements are important for the future sharing of foreign policy responsibilities between the central government and the AC's ("El TC dice que la bilateralidad no significa relación entre iguales y no afecta a competencias estatales" 2010). First, the Court judged that, relative to article 174.3, the Generalitat had to follow the state's legislation and that no institution (that is, a bilateral commission between Spain and Catalonia) could substitute for the decision-making bodies of the state nor lessen or prevent the free and full exercise of these jurisdictions. ${ }^{41}$ Second, article 183.1 (regarding the bilateral commission of Spain-Catalonia) interpreted the Commission as an "incentive" organization, not a binding one for Spain, ${ }^{42}$ meaning that it could encourage Spain to take a specific decision, but not force it to.

\subsection{Competing visions of foreign policy}

The high point of Catalonia's foreign policy is the revised Statute of Autonomy (2006). In short, Catalonia wants more say in European institutions for issues related to its own jurisdictions. The high point of Spain's foreign policy is the 1997 law institutionalizing

41 "En definitiva, el art. 174.3 EAC ha de interpretarse en el sentido de que prevé una participación orgánica y procedimental de la Generalitat que habrá de ser regulada por la legislación estatal y que no puede sustanciarse respecto de los órganos decisorios del Estado ni impedir o menoscabar el libre y pleno ejercicio de las competencias estatales" (Tribunal Constitucional 2010, par.111).

42 "la participación del Gobierno de la Generalitat cerca del Gobierno del Estado ha de limitarse a la típica facultad de estímulo e incentivación del ejercicio de una determinada competencia por quien es su exclusivo titular jurídico. Es decir, a una facultad de acción política que sólo compromete en el ámbito político que le es propio y al que necesariamente se contrae" (Tribunal Constitucional 2010, par.115). 
the input of the AC's in Spain's decisions before the EU, via CARCE. As is discussed in the next section, the foreign policies of Catalonia and Spain became less confrontational in the late 1980's to early 2000's. Yet, hopes for further involvement by Catalonia in the EU came to a halt in 2010 with the judgment of the Constitutional Court on Catalonia's revised Statute of Autonomy.

\subsubsection{Competition between Barcelona and Madrid in foreign policy}

The following time line lists the actions related to the foreign policies in Catalonia and Spain since the late 1970 's. The definitions of the categories are as described previously. 
Illustration 5: Time Line of Actions in Foreign Policy of Catalonia and Spain

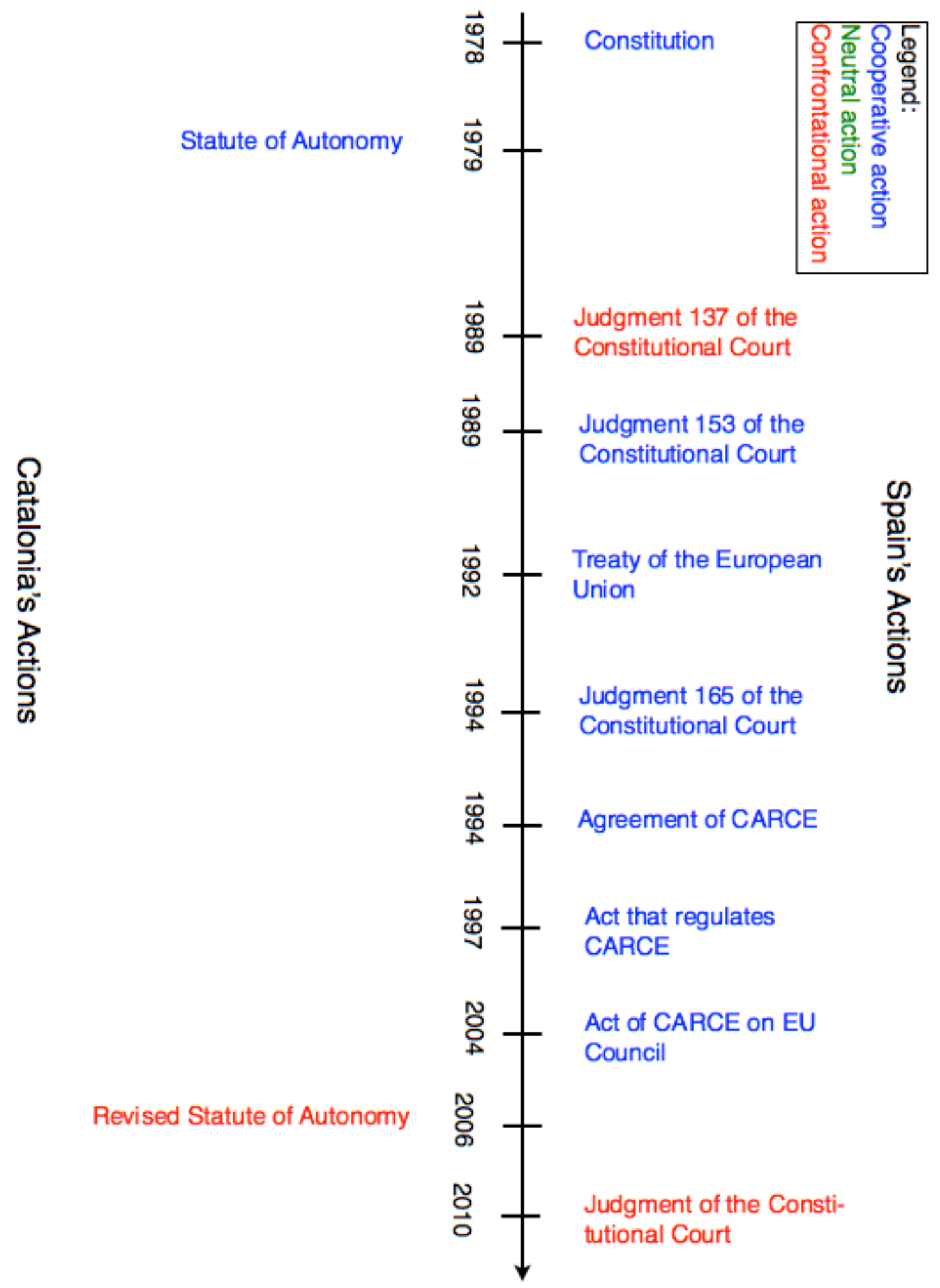


At the beginning of the transition period after Franco's death, in the late 1970's, Spain's central government clearly perceived itself as the only representative of the country on the international scene. Throughout the 1980's, the Constitutional Court aligned its judgments with this view and challenged the tentative international activities of all AC's. However, participation in European institutions brought seemingly more influence of the AC's in matters under their own jurisdiction, provoking a series of cooperative actions by Spain towards Catalonia's (and all AC's') international activities. The CARCE was created, bringing an appearance of a more important role to AC's both in Spain's foreign policy and in their own international activities.

Still, Catalonia, and other AC's, were hoping for more influence in Spain's foreign policy in matters related to their own jurisdictions, notably via a bilateral commission constituted between Catalonia and Spain, as proposed in its revised Statute of Autonomy of 2006. The influence of Québec's doctrine Gérin-Lajoie is apparent in Catalonia's demands: the latter wants, just like Québec, to have its say and be responsible for its jurisdictions abroad. The Constitutional Court, when judging the 2006 Statute, stipulated clearly that Catalonia would not obtain these powers: Spain remains formally in charge of important decisions outside of its borders. Catalonia (and other AC's) can give their opinion, but not much more. All interviews conducted in Madrid and Barcelona in Spring of 2012 concurred: the EU did not change significantly the foreign relations powers of Catalonia before Madrid. This is a more nuanced view than the one presented by the existing academic literature (García Segura and Pareja Alcaraz 2003; Garcia Segura 2008). The EU deals with the countries, not regional governments (Lecours 2002). It 
imposes laws, directives, and regulations, that the countries (not the regions or the AC's) must apply. It only negotiates with the central governments' ministers, even if the topic does not pertain to their jurisdiction. Moreover, these laws, directives, and regulations have to be applied uniformly across countries. For example, the EU imposed a law on Spain's budget in early 2012. Spain had to apply it, otherwise sanctions would have ensued. As a result, Spain imposed cuts on AC's without consulting them (Interview with Carles Viver 2012).

\subsection{Conclusion}

The foreign policies in Québec-Canada and in Catalonia-Spain differ in the response that the majority nation's governments offered to the minority nation's governments. In Québec, after a series of confrontational actions, the federal government agreed to the Gérin-Lajoie doctrine in the early 2000's. Nowadays, the foreign policies of Québec and Ottawa are aligned with one another and tend definitely more toward cooperation than confrontation. In Catalonia, the competition in foreign policies has reached, since the revised Statute of Autonomy in 2006, a climax of confrontation. However, in the 1990's, the foreign policies of Barcelona and Madrid seemed to align more and more.

What explains the difference in the dynamics between Québec-Canada and Catalonia-Spain in terms of foreign policies? The influence of France in the case of Québec and the apparent-but-rather-ineffective influence of the EU in the case of Catalonia gives a partial answer. The former organized for Québec to have a presence at international meetings in the late 1960's and early 1970's. While this dissertation does not pretend to offer a full coverage of the French diplomacy in these decades, it seems likely 
that Paris had positioned itself as a stronger power over Francophone countries than Ottawa had. And Québec was willing to play according to France's idea of a Francophonie organization, probably because it perceived this external helper as an opportunity to advance its foreign policy with a big step within Canada. The dynamics in Catalonia-Spain are different. Even though the EU apparently gave a larger role to the regions (these include Spanish AC's), in reality, it did little to advance the foreign policy of Catalonia within Spain. Throughout the 1990's, the Constitutional Court incrementally favored an augmentation of Catalonia's powers in matters of foreign policy. Also, the EU encouraged Spain to pursue the CARCE (which became the CARUE) and thus gave a arena where Barcelona and Madrid could meet to discuss EU matters. Nonetheless, civil servants interviewed in Catalonia on this topic were adamant that this had not advanced the powers of the AC in questions related to the EU (Interview with Carles Viver 2012; Interview with Débora Miralles Solé 2012). In 2006, with the revised Statute of Autonomy, Catalonia sought to advance in an significant way its foreign policy. This was met with a rejection from the Constitutional Court and Catalonia-Spain are nowadays under macro-confrontation.

Episodes of macro-confrontation in both Québec-Canada and Catalonia-Spain also influenced the dynamics of the foreign policies. In 1995, the year of the referendum and the year when Ottawa issued "Canada in the World," the relations with Québec reached a maximum of confrontation. This 1995 action by the federal government inspired Québec to write a "Déclaration concernant la participation aux forums internationaux" as well as to enact two laws in the early 2000's. Currently, in Catalonia, 
the macro-confrontation is occurring in part because of the rebuttal faced by the 2006 Statute and in part because of the consequences of the financial crisis (discussed in chapter 6). These episodes of macro-confrontation affected all policies studied in this dissertation. In both of these instances, the citizens of the minority nations wanted the minority nation's government to have more power in foreign policy because the majority nation's government did not reflect enough the minority nation's jurisdictions on the international scene. 


\section{Competition through immigration policy}

This chapter describes the competition in Québec-Canada and in Catalonia-Spain, in light of the model presented earlier, for the specific field of immigration policy. Immigration policy is of particular importance for minority nations. For Québec, in 2006, 11.5\% of the population was of foreign origin (Immigration et Communautés culturelles du Québec 2011, 2); in Catalonia, it was $16.4 \%$ in 2010 (Generalitat de Catalunya 2010). In comparison, for Canada, $19.8 \%$ of its population was born outside the country in 2006 (Citoyenneté et Immigration Canada 2011) and Spain had 14.2\% of its population born outside the country in $2011^{43}$ (Instituto Nacional de Estadística 2011, calculated by the author).

The immigration policies of Québec and Canada have been cooperative since the later 1960's. Nowadays, Québec selects most of its immigrants, while Ottawa remains responsible for refugees and family reunification. In fact, Québec and Ottawa have a clear and written procedure (in the form of the 1991 Agreement) for deciding which immigrants settle in Québec. By contrast, Barcelona has very little influence in Madrid's decisions over immigration; rather, the central government of Spain has full power. Some commentators claim that Catalonia "should" have more power, citing the examples of Québec and Flanders (Zapata-Barrero 2006, 2009a).

Indeed, the two cases studied present different situations. Québec-Canada appears to offer a case of almost full cooperation between their respective immigration policies, and Catalonia-Spain seems increasingly confrontational. The fact that these two relatively

43 According to this source, Spain had a total population of $47,190,493$ people, of which $6,677,839$ were born outside its territory. 
similar minority nations have very different powers vis-à-vis their central governments when it comes to immigration is a puzzle - hence making for an interesting comparison. What factors lead to these apparently opposite situations? How do the minority nation's government and the majority nation's government deal with each other when it comes to immigration policy? How have the competitive dynamics played out since the 1970's? Why do Québec-Canada and Catalonia-Spain offer such different perspectives when it comes to immigration policy?

The rest of this chapter begins by describing the immigration policy of Québec and the immigration policy of Canada since the 1960's, the period that corresponds to the rise of the nationalistic movement in the province. Then, it describes the immigration policy of Catalonia and that of Spain since the late 1970's, commencing with the end of Franco's dictatorship. Finally, it presents the results in a time line summarizing the events for each case. This chapter matches the model described earlier. Starting in the 1960's, the Québec government has been demanding more powers in immigration from the federal government - and Ottawa has agreed to it little by little. The federal government has acquiesced to these demands for a few reasons. First, it was encouraged to do so by the Constitution (article 95 stipulates that immigration is a shared jurisdiction). Second, acquiescing to this growing power in Québec promoted the image of a federal government that cared about the preserving of French in Canada - hence potentially favouring the loyalty of the citizens to the majority nation. Immigration policy is not a case of confrontation between Québec and Ottawa: it is probably the closest to perfect cooperation of all the cases studied in this thesis. The 1991 Agreement binds the two 
parties to the way they assess immigrants' applications. It is a written procedure, carefully followed and to which both governments refer as part of their daily interactions (Interview with anonymous civil servant employed at Citizenship and Immigration Canada 2012). On the contrary, Catalonia started demanding more powers in immigration in the 1990's and wanted many powers all at once. One could say that the federal government did not see it coming. As a result, it refused to make any significant concession of immigration powers to the AC. The Spanish government sees immigration as its own policy and seeks to promote a pure Spanish loyalty. This is still the situation in 2013.

\subsection{Immigration policies in Québec and in Canada}

In the 1960's, immigration policies in Québec and in Canada epitomized the increasing influence that the Québec government wanted to have over the identity of the minority nation. Canada agreed to the demands of Québec for control over immigration, and the issue has been cooperative since the 1960 's. Nowadays, the sharing of immigration policy still appears to be au beau fixe between the two governments.

\subsubsection{Before the 1960's}

The 1867 BNA Act stipulates in article 95 that immigration is a shared jurisdiction between the provinces and the federal government. Yet, from the beginning of Confederation, immigration policy was entirely controlled by the federal government. It was centered on the desire to have immigrants assimilate to the mainstream population (Reitz 2004, 123-124). Immigrants assimilated mainly to the English population, even in 
Québec (Reitz 2004, 121-122). Information on immigration in Canada was only available in English (Brossard 1967, 100-102; Labelle and Rocher 2009, 62). Indeed, of the 2.5 millions of immigrants to Canada between 1945 and 1965, 60\% were Anglophone and 3\% were Francophone (Brossard 1967, 121). Kelley and Trebilock observe that, in Canada in 1867, immigration was seen as an instrument to develop the economy of the country: "Following Confederation, immigration policy was regarded as one of the cornerstones upon which the new nation would develop. For Canada to survive as an independent, prosperous nation, economic growth was essential and, in turn, was dependent upon a larger population and an expanding market" (2010, 12-13). And, as immigration was to be used as a tool for economic development,

"[Anglo-Canadian nationalists'] concern was principally with the development of a homogenous society based on British values, traditions, and institutions. Anglo-Canadian nationalists pressed for an immigration policy that was selective and that promoted British immigrants over all others. Their demands were sharply at variance with those of French Canadians, who were concerned that the linguistic and cultural balance that existed at the time of the Confederation not be upset. Amid these competing concerns and values, economic interests held paramountcy within the government, not only for the first thirty years after Confederation, but throughout most of the next halfcentury as well" (Kelley and Trebilcock 2010, 13-14).

But the federal government was not the only one to blame for the weak assimilation of immigrants to French. Québécois before the 1960's have been described as "hostile" towards immigrants (Brossard 1967, 20) or "xenophobic" (Daniel 2006, 45). Also, the birthrate in Québec was higher than in the rest of Canada until the 1960's, hence the lesser concern about the integration of immigrants in the province. In Québec, the birthrate went from 37.6 for 1,000 women in 1921 to 29.3 in 1945, down to 21.7 in 1965 (Institut de la statistique du Québec 2012). In Canada (as a whole, including Québec), it 
went from 29.3 to 24.3, down to 21.3 for the same years (Statistics Canada 2008). Otherwise said, Québec's relatively high birthrate, until the mid-1960's, lessened the concern for attracting immigrants to the province.

\subsubsection{After the 1960's}

Most historians agree that the Quiet Revolution was a turning point for Québec's nationalism. In 1968, the Québec government created its ministère de l'Immigration (Labelle and Rocher 2009, 62). Slowly, but increasingly, it demanded more and more

powers from the federal government. These demands culminated with the Agreement of 1991, still in force today.

\subsubsection{Ministère de I'Immigration (1968)}

As explained in the chapter on linguistic policy, in the 1960's, Québec was worried about immigrants choosing English over French. Coupled with a decreasing birthrate, the longterm preservation of Québec's distinct French identity appeared increasingly in doubt. On top of that, nationalism was growing within the province. In addition, the Constitution did say that immigration was a shared jurisdiction.

Since 1965, Québec had a Service of Immigration within the ministère des Affaires culturelles. It wanted to go further. The new department, the ministère de l'Immigration du Québec, was announced by both the Secrétaire of Québec, Yves Gabias, and the federal minister of Citizenship and Immigration, Jean Marchand, in February of 1968. Two reasons were the cause: the decreasing birthrate and the diminution of French immigrants. Yves Gabias reported that, in 1967, births had gone down by 23\% in Québec 
and that demographers were announcing the "drowning" of Québécois within the next 15 to 50 years (Le Québec se dote d'un ministère de 1'Immigration 1968). The department was to post Québec's representatives in all Canadian immigration offices located in French-speaking countries, and to have them target Francophones in the promotion of immigration to Québec. The federal minister, Jean Marchand, said that this action was perfectly compatible with the Constitution; that it wanted to protect the "French fact" in North America; that Québec was the best to decide which immigrants were most likely to adapt to Québec; and that the federal government was to "fully collaborate" with Québec (Le Québec se dote d'un ministère de l'Immigration 1968).

The ministère de l'Immigration of Québec was created to foster the cultural identity of a "collectivité nationale distincte" (Robic 1987, 577). The federal government seemed fine with that. Clearly, the two governments were working hand in hand to promote French immigration to Québec: it was cooperation without a doubt. Québec opened two offices, in France and Italy. It also created seven centres in the province for the learning of French by immigrants.

\subsubsection{Cloutier-Lang Agreement (1971)}

In 1968, Québec started asking the federal government that representatives of the province be allowed in the foreign offices of Canada. The federal government finally agreed to it (Daniel 2006, 49). But it made sure to specify that Québec was not receiving a favour refused to other provinces.

The 1971 Cloutier-Lang Agreement sought to "render possible and facilitate the presence of an orientation officer and a secretary-clerk-interpreter, both in the employ of 
the Department of Immigration of Quebec, within federal immigration offices outside Canada" (Lang and Cloutier 1971, par.2). The Québec officers could provide information to potential and accepted immigrants, but application for immigration remained entirely the domain of the federal government (Lang and Cloutier 1971, par.10). It was clearly indicated that Québec was not, via this agreement, receiving any special treatment:

"[this agreement] does not have as its objective or effect to place the Quebec government in a privileged position in the field of immigration recruitment and selection, as compared to the other provinces, but to enable a Quebec Orientation officer to receive, and to advise, counsel and assist an immigrant who has chosen Quebec as his place of settlement before the immigrant departs" (Lang and Cloutier 1971, par.11).

Despite this mise en garde from the federal government, the cooperation between it and the Québec government was yet far from its final stage. Over the next decades, the cooperation would only keep growing.

\subsubsection{Bienvenue-Andras Agreement (1975)}

In 1974, the Minister of Immigration of Canada Robert Andras presented a Green Paper in which he recognized that immigration was a shared federal-provincial jurisdiction. Moreover, among the problems faced by Canada was "the decline of francophones as a percentage of the population" (Kelley and Trebilcock 1998, 372). This Green Paper was followed by public consultations and laid the groundwork for the new law of 1976 (Kelley and Trebilcock 1998, chap.9; Labelle and Rocher 2009). Meanwhile, in October of 1975, the federal government and the Québec government signed a new Agreement concerning information, recruitment and selection of foreign nationals residing outside of Canada for permanent residence or temporary employment in the Province of Québec, 
also called the Bienvenue-Andras Agreement thanks to the names of the ministers responsible for immigration, respectively in Québec and in Canada.

This agreement held that Québec and Ottawa would, together, plan the policy over immigration and temporary residence in Québec (Bienvenue and Andras 1975, par.1). The two governments would share information regarding applications; consult one another on recruitment and selection of applicants; and communicate about immigration processes (Bienvenue and Andras 1975, par.1). Québec and Canada would seek a consensus if their opinions were to diverge, but Canada would have the last say (Bienvenue and Andras 1975, par.2, Addendum No.1).

What is more, Québec and Canada both officially recognized that this agreement was a step toward an era of increasing cooperation relating to immigration: "[considering] the increasingly cordial contacts and the growing co-operation that has developed between the two parties, particularly within the framework of the previous Agreement signed on May 18, 1971; [the] parties to this Agreement are determined to consult on matters concerning the implementation of a program relating to" information, recruitment, selection, and communication of immigrants and temporary workers in Québec (Bienvenue and Andras 1975, 4-5).

Yet, it remains unclear what exactly encouraged the Canadian government to sign the agreement. Two reasons stand out. On the one hand, the sovereignty threat from Québec was salient given the crisis of 1970. The Green Paper of 1974 showed concern for the fate of the minority nation by explicitly stating that the decreasing proportion of Francophones was among the problems of the country. On the other hand, article 95 of 
the BNA Act stipulates that immigration and agriculture are shared responsibilities. There is probably not much else to understand from this federal evidence of cooperation: the preamble of the 1975 Agreement itself lists article 95 as the first consideration, followed by the selection of French-speaking immigrants in Québec with "due regard for the economic, demographic and socio-cultural needs of Québec" (Bienvenue and Andras 1975, 4).

\subsubsection{Immigration Act (1976)}

The Immigration Act of Canada, passed in 1976 but enforced starting in 1978, established, in accordance with international treaties (notably the 1951 United Nations (UN) Convention Relating to the Status of Refugees and its 1967 Protocol), that specific categories of immigrants would be welcomed to Canada (Canada 1976, art.2). Canada needed this new law: in the previous years, the federal government had been criticized for its poor management of immigration issues, in particular cases with refugees (e.g., the Chilean crisis of 1973). As Kelley and Trebilock put it, when the federal Minister Andreas assumed his position (in 1972) and commenced the process of designing the legislation, "Managerial problems and an illegal immigration backlog spiralling out of control caused deep morale problems among immigration officials" $(1998,371)$.

The objectives were clearly stated: to promote the attainment of demographic and economic goals of Canada and to honour international treaties (Canada 1976, art.3). Regarding the former, applicants whose medical costs would constitute a burden for Canada, who have weak economic autonomy, and those who show a criminal potential, were to be refused immigration to Canada (Canada 1976, art.19). In line with 
international obligations, the assessment of refugees was stipulated (Canada 1976, art.3g,6,45-48,115). More importantly, the minister of Immigration would henceforth be obliged to consult provinces' objectives for immigration every year and report it to the Parliament (Canada 1976, art.7). And the same minister would be entitled to sign agreements with provinces in order to coordinate with their immigration policies (Canada 1976, art.109). This was the "first time" that the federal government recognized "in practice" that immigration was a shared responsibility with provinces (Kelley and Trebilcock 1998, 391).

\subsubsection{Couture-Cullen Agreement (1978)}

In accordance with the 1976 Immigration Act of Canada, Québec and Canada signed, in 1978, an agreement granting Québec more say in the selection of immigrants - the Agreement between the Government of Canada and the Gouvernement du Québec with regard to co-operation on immigration matters and on the selection of foreign nationals wishing to settle either permanently or temporarily in Québec, also known as the Couture-Cullen Agreement. Henceforth, Québec would decide the criteria for applicants under the categories of independent immigrants (some of them), temporary workers, students, post-secondary education teachers, and medical-reason tourists. Kelley and Trebilcock report that "Federal officials hailed the agreement as "proof of the flexibility that exists in the current federal system" " $(1998,392$, quoting "Immigration: Quebec Signs," Winnipeg Free Press, 21 February 1978).

This new agreement came at an important time for Québec. Day and Winer document how the 1976 election of the PQ led to a net outflow from Québec of between 
26,349 and 33,172 people (2012, 251-252). Moreover, this immigration shock likely affected high-income taxpayers more than low- and middle-income ones (Day and Winer 2012, 252). Of course, this is an important, perhaps even dramatic, result for any government and Québec certainly had to take action in order to preserve its demographic weight within Canada.

In practical terms, the two governments were to set up a Joint Committee whose mandate would satisfy the requirements of article 109 of the 1976 Immigration Act: harmonize both parties' objectives relating to immigration, and coordinate immigration policies from both governments (Gouvernement du Canada and Gouvernement du Québec 1978, II). On top of that, the Joint Committee was to establish processes to deal with special issues relating to immigration (Gouvernement du Canada and Gouvernement du Québec 1978, II). That is, the federal government would not admit visitors without the prior agreement of Québec (Gouvernement du Canada and Gouvernement du Québec 1978, III, par.5). However, family reunification and refugees remained the domain of the federal government (Gouvernement du Canada and Gouvernement du Québec 1978, Preamble).

\subsubsection{Immigration Policy (1990)}

In 1990, Québec could already participate in the selection of a few categories of immigrants (notably workers and students), but novel demands in the 1990 policy included the selection of more categories of immigrants (notably investors and more types of independent immigrants), and the integration of concern for the demographic weight of Québec within Canada; that is, a consideration for maintaining the French 
proportion of Canadians (Ministère des Communautés culturelles et de l'Immigration du Québec 1991, 24; Young 1991).

The 1990 Immigration Policy focuses first on the contribution of immigration to the economic development of Québec, mainly because native Québécois have few children. However, it mentions repeatedly that the adoption of French by immigrants is necessary to ensure social cohesion. The first principle of the policy is that French is the common language of public life in Québec (Ministère des Communautés culturelles et de l'Immigration du Québec 1991, 16) and its first objective is to increase the proportion of French speakers among immigrants ${ }^{44}$ (Ministère des Communautés culturelles et de l'Immigration du Québec 1991, 26). In short, the immigration policy of Québec highlights the importance of learning or knowing French for immigrants in order to guarantee their integration to a society designated as Francophone. The federal government would soon respond favourably to the Québec demands related to immigration.

\subsubsection{Gagnon-Tremblay-McDougall Agreement (1991)}

In 1991, the Couture-Cullen Agreement came to an end and was replaced by the GagnonTremblay-McDougall Agreement, that is, the Canada-Québec Accord relating to Immigration and Temporary Admission of Aliens. From then on, the responsibilities of

44 More recently (and in continuation of the Commission de consultation sur les pratiques d'accommodement reliées aux différences culturelles, also called Bouchard-Taylor Commission), Québec has asked those who fill out a "Demande de certificat de sélection du Québec" to sign the "Déclaration sur les valeurs communes de la société québécoise." After a list of the six values, it is highlighted that "La société québécoise est aussi régie par la Charte de la langue française qui fait du français la langue officielle du Québec. En conséquence, le français est la langue normale et habituelle $\mathrm{du}$ travail, de l'enseignement, des communications, du commerce et des affaires" (Ministère de l’Immigration et Communautés culturelles du Québec 2008, 12). 
each government relating to immigration were stated explicitly (Labelle and Rocher 2009, 62-65).

On the one hand, Canada would decide on the general criteria of immigration: "defining the general classes of immigrants and classes of persons who are inadmissible into Canada, by setting the levels of immigration and the conditions for the granting of citizenship, and by ensuring the fulfillment of Canada's international obligations" (Gouvernement du Canada and Gouvernement du Québec 1991, art.3). On the other hand, Québec would make decisions that concerned immigrants settling in the province: "Québec has the rights and responsibilities set out in this Accord with respect to the number of immigrants destined to Québec and the selection, reception and integration of those immigrants" (Gouvernement du Canada and Gouvernement du Québec 1991, art.4). Otherwise said, Québec would be responsible for the "selection" and, Canada, for the "admission" of immigrants (Gouvernement du Canada and Gouvernement du Québec 1991, art.12). Québec's immigration policy would seek to admit a percentage of immigrants equal (plus up to $5 \%$ greater) to the proportion of its population within Canada (Gouvernement du Canada and Gouvernement du Québec 1991, art.5-7). More specifically, Canada would be the sole arbiter regarding matters of family reunification (Gouvernement du Canada and Gouvernement du Québec 1991, art.13-16). The decision would be joint (from both Canada and Québec) for refugees not already in Québec (Gouvernement du Canada and Gouvernement du Québec 1991, art.17-20). Québec would decide for "sponsors," students ${ }^{45}$, temporary workers, and foreign visitors

45 Québec does not decide for "[students] chosen under a Canadian government assistance program for developing countries" (Gouvernement du Canada et Gouvernement du Québec 1991, art.22a). 
(Gouvernement du Canada and Gouvernement du Québec 1991, art.21-22). Finally, Canada would give "reasonable compensation" to Québec for cultural, linguistic, and specialized economic integration of immigrants to Québec (Gouvernement du Canada and Gouvernement du Québec 1991, art.24-26). Thus, the two main requests contained in the 1990 Immigration Policy of Québec were accepted: Québec would have a say in the selection of more categories of immigrants (notably investors and some types of independent immigrants) than before, and the integration of concern for the demographic weight of Québec within Canada would be taken into account.

In an interview, a federal civil servant at the Department of Citizenship and Immigration Canada stressed that all contacts, all discussions, all decisions related to immigration between the two governments refer to the 1991 Agreement - the civil servant even called it "the Bible." This formal rapport between Québec and Ottawa avoids confrontation related to administrative matters, with the possible drawback of causing policy changes (in order to fit with current reality) to be more challenging (Interview with anonymous civil servant employed at Citizenship and Immigration Canada 2012). One example provided in the interview consisted of the calendar stipulated in Appendix A, section III (Gouvernement du Canada and Gouvernement du Québec 1991): the calendar does not match the government's present processes (e.g., when data are available about the number of immigrants hoped for the next year). As of June of 2012, discussions were occurring between Québec and Ottawa about changing the calendar to match with current reality within the government (Interview with anonymous civil servant employed at Citizenship and Immigration Canada 2012). (This only represents the perspective of the 
federal government. It was impossible to obtain the perspective from the Québec government on immigration policy.) According to the MP in charge of immigration in the opposition party in Québec in Summer of 2012, Yves-François Blanchet, the administrative relation between Québec and Ottawa is well organized, but the federal government applies a system of values that does not fit with Québec's (Interview with Yves-François Blanchet 2012). Moreover, he said that the office of the federal minister of Immigration does not pick up the phone when the then-Premier of Québec, Jean Charest, calls (Interview with Yves-François Blanchet 2012). Yet, this formalized relationship is certainly a great example that relations between the two governments - even on a terrain that is at the core of the minority nation's survival, immigration - can be cooperative.

The 1991 Agreement arguably exemplifies the height of the cooperation that can exist between governments of a majority nation and a minority nation for a specific public policy. Kelley and Trebilcock see it as a response to the defunct Meech Lake Accord: "Hoping perhaps to minimize the political fall-out of the rejection of the Meech Lake constitutional accord in 1990, the federal government and Quebec Premier Robert Bourassa immediately began bilateral negotiations designed to transfer additional immigration powers to Quebec" (Kelley and Trebilcock 1998, 392-393). It appears that the political context served Québec's requests in 1991 - the federal government certainly wanted to appear considerate towards Québécois, but Québec and Ottawa were already on a path of cooperation in matters of immigration. The 1991 Agreement is a continuation of reinforced cooperative actions. 


\subsection{Competing visions of immigration policies}

The high point of Québec's and Canada's immigration policy is certainly the GagnonTremblay-McDougall Agreement of 1991. In it, the immigration jurisdiction of the minority nation is clearly stipulated and, with the exception of humanitarian immigrants, shielded from the central government's influence. Compared to the two other policy domains studied and compared to immigration policy for Catalonia, the progression towards full cooperation between Québec and Ottawa over immigration policy appears as a unique case. Within two decades, a minority nation's government and a majority nation's government were able to increase their cooperation over a policy domain and, afterwards, maintain it for a least two more decades.

\subsubsection{Competition between Québec and Ottawa in immigration policy}

The following time line lists the actions related to the immigration policy in Québec and Canada since the 1960 's. In the time line, each action is ascribed to one of three categories, in accordance with the definitions presented earlier. 
Illustration 6: Time Line of Actions in Immigration Policy in Québec and Canada
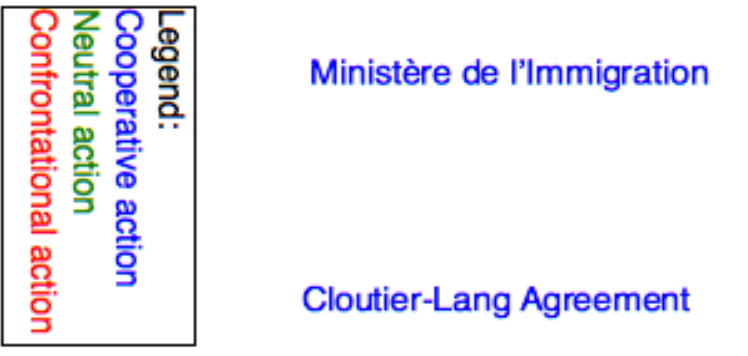

Bienvenue-Andras Agreement

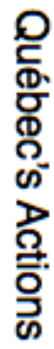

Immigration Policy

Gagnon-Tremblay-McDougall Agreement
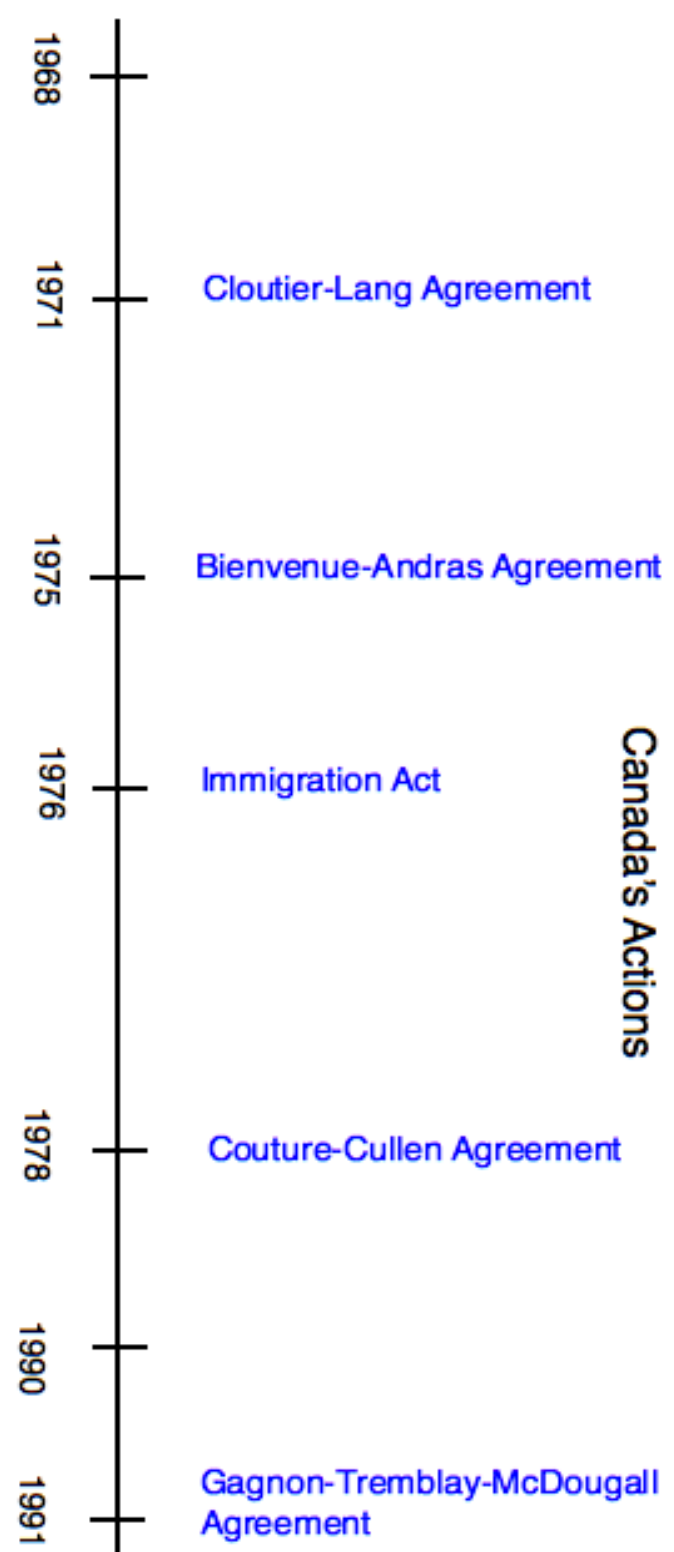
The immigration policy in Québec and Canada certainly depicts a different dynamic than the one revealed from the study of the linguistic and foreign relations policies. Here, agreements were signed as the sharing of power was increasingly going towards greater jurisdiction on the part of the minority nation's government. Overall, little tension between the two governments is perceptible. The reason might be straightforward: the 1867 BNA Act stated that immigration was a shared jurisdiction between provinces and the federal government. It is reasonable to presume that the perceived threat of a Supreme Court's decision if the federal government were to refuse powers to Québec was a good enough impetus for agreeing with the province on this matter. Also, in the 1980's, within the constitutional debate (with the referendum in 1980 and Meech Lake Accord in 1987), the cooperation from the federal government in matters of immigration provided a great display to Québécois that Ottawa understood the concerns for the preservation of their minority nation. But these reasons could have been invoked for linguistic and foreign policy - otherwise said, immigration policy did not have to be as cooperative as it has been. What stands out here is that both nations responded favourably to the other nation's actions. The game was one of continuous positive reinforcement. Moreover, Québec asked for more powers (at least in the official discourse) in an incremental way. Therefore, the federal government had less to change every time and both governments could witness the absence of drawbacks from this increasing cooperation. As the following will show, this never happened between Spain and Catalonia for immigration policy. 


\subsection{Immigration policies in Catalonia and in Spain}

Before the end of the Franco dictatorship in 1975, immigration to Spain was scarce. It increased slowly as Spain transitioned to democracy and, parallel to that, became an economic pole of attraction for emigrants. Catalonia tacitly left all immigration policy to the central government - that is, until the 1990's. Catalonia then started demanding more power over immigration, climaxing around the revision of the Statute of Autonomy in 2006.

\subsubsection{Before the 1970's}

There was no net immigration to Spain under Franco. In fact, it was the opposite: Spaniards and Catalans were emigrating to other European countries and to the Americas. In the 1950's, Spaniards emigrated to Latin America and France: "In 1960, it is estimated that close to 1.3 millions Spaniards were living in Latin America (715,685 in Argentina), while in France the numbers were up to almost 450,000" (Romero Valiente 2004, 225, author's translation). In the late 1950 's, the trend started changing for emigration to Western Europe (Germany, France, and Switzerland). In the early 1970's, more than 2.5 millions Spaniards lived outside Spain, ten times the number of foreigners residing in the country (Romero Valiente 2004, 225, author's translation).

\subsubsection{After the 1970's}

As discussed in the previous chapters, after Franco's dictatorship, the transition to democracy commenced in Spain. The Constitution of Spain was signed in 1978. 
Following the Constitution, Catalonia enacted its Statute of Autonomy in 1979. These two fundamental documents agree that immigration policy is the central government's jurisdiction.

On the one hand, article 149.1 of the Constitution stipulates: "The State shall have exclusive competence over the following matters:[...] (ii) Nationality, immigration, emigration, status of aliens, and right of asylum" (Cortes Generales de España 1978). On the other hand, Catalonia's Statute of Autonomy recognizes Spain's exclusive competence in matters of immigration policy in articles 11 and 13. It is written that the Spanish government has all responsibilities related to domestic and foreign migrations (Generalitat de Catalunya 1979, art.11.3). Also, the Spanish police - not Catalan - is in charge of customs, entry and exit of the country by foreigners and citizens, extradition and expulsion, control of the borders, emigration and immigration, identity documentation, and so on (Generalitat de Catalunya 1979, art.13.4).

There was a consensus between Madrid and Barcelona in the late 1970's; the Spanish government was to deal with everything related to immigration policy. In any case, the transition to democracy did not attract many non-Spaniard immigrants to Catalonia or Spain. Immigration was not a concern until the 1990's (Zapata-Barrero 2006, 195). In fact, "[until] early 1992, the immigration office in the Ministry of Labor was anachronistically called the 'Spanish Institute of Emigration' " (Cornelius 2004, 387). In 1985, Spain enacted its first immigration law, the Ley Orgánica 7/1985 de 1 de julio sobre Derechos y Libertades de los Extranjeros en España (literally, the Act on Rights and Liberties of Foreigners in Spain). Cornelius describes it as a "highly restrictive law 
[that] was almost entirely the result of external pressure associated with Spain's entry into the European Union on January 1, 1986" (2004, 404). The newspaper El Mundo claims that this law was described by some social organizations as one of the toughest in Europe and that it was enacted because Spain, which was about to enter the EU, did not want to become an entry point to the continent (Quílez 2005, author's translation). This law was accompanied by a "proceso extraordinario de regularización" (literally, an extraordinary process of regularization) that was not successful (in the sense that it regularized few illegal immigrants) and encouraged Spain to take other measures (Cornelius 2004, 412).

\subsubsection{Interdepartmental Immigration Committee (1993)}

In 1991, Spain carried a second extraordinary process of regularization for more than 100,000 immigrants on its territory (Gozálvez Pérez 1996, 17). According to Cornelius (2004), two reasons motivated this extraordinary legalization program. First, a survey "found that the vast majority of illegal immigrants already residing in Spain intended to stay and, eventually, bring their families" (2004, 412). Second, "major newspapers had published inflated estimates of the numbers of illegal immigrants, alarming public opinion; labor unions, along with immigrant rights and church groups, were pressing for a broad amnesty" (2004, 412). In fact, it was presented as a way of finishing the 1985 extraordinary process of regularization (Gallarín and Fernández 2002, 9).

After the 1991 extraordinary process of regularization, many segments of society in Catalonia demanded greater support for immigrants. The most important was perhaps “L'Informe de Girona: 50 propostes sobre immigració,” published in 1992 (Generalitat de Catalunya 2009, 60). This document was written by the Comissió d'Associacions i 
Organitzacions no Governamentals de les Comarques de Girona (literally, the Commission of associations and non governmental organizations of the counties of Girona) (Romero 2001, 201, 205). Among other things, “L'Informe de Girona” requested education for all children, be they from illegal immigrant parents or not. In response to this popular uproar, the Generalitat created the Comissió per al seguiment i la coordinació de les actuacions en matèria d'immigració (literally, the Commission for monitoring and coordinating immigration actions) (Generalitat de Catalunya 2009, 60). This Commission, in turn, wrote a report on immigration in Catalonia. As a result, the Generalitat presented, in 1993, a "Pla interdepartamental d'immigració (1993-2000)"46 (literally, an "Interdepartmental Immigration Plan") and created the Comissió Interdepartamental d'Immigració (the Interdepartmental Immigration Committee) as well as 40 programs related to immigration. The main development of this Committee was that, under it, immigration began to be treated as an interdepartmental (to be understood as important) problem by the Generalitat.

\subsubsection{Act on Rights and Liberties of Foreigners in Spain and their Social Integration (2000)}

In January of 2000, Spain passed the Ley Orgánica 4/2000 sobre derechos y libertades de los extranjeros en España y su integración social (literally, the Act on Rights and Liberties of Foreigners in Spain and their Social Integration). Two articles are of importance for AC's. Firstly, article 68 of the 2000 act establishes that the central

46 This Plan established the policy of immigration to Catalonia with the following objectives: "promoting a global policy of integration, establishing and carrying out a series of consistent and coordinated services and resources programmes, driving the participation of immigrants in Catalonia's nation building and promoting information for and awareness about the issue among the population at large, and especially for people working in related fields" (Generalitat de Catalunya 2009, 61). 
government will coordinate with the AC's in terms of immigration via the Sectoral Conference on Immigration (España 2000, art.68, par.1). Secondly, article 39 specifies that the minister of Work and Immigration of Spain will take into account the projections of needed workforce submitted by AC's when deciding the numbers of work visas to be allowed each year, and the management of residence permits (for work visas and work permits) will be done in coordination with AC's (España 2000, art.39, par.1,2). In the same line, the Spanish government is to collaborate on temporary (seasonal) work immigration with AC's (España 2000, art.42, par.1).

This represents, from Spain, a very quick mention of the AC's in the immigration policy. The Generalitat considers it the first mention by the central government of the involvement of AC's in the process (Generalitat de Catalunya 2008a, 83). It does, indeed, recognize that AC's are entitled to the respect of their own responsibilities when it comes to immigration. In particular, AC's are responsible for their workforce regulations and for the enforcement of residence regulation by their own police (España 2000, art.68, par.2,4) ${ }^{47}$

It seems that this act caused the appearance of an opening in Madrid as to what AC's could do in matters of immigration. Three official documents that followed the 2000 act are worth mentioning. First, the 2000 act entailed an extraordinary process of regularization, with the particularity (contrarily to previous regularizations) that AC's were involved. Depending on immigration within their borders, the AC's could process the applications (Gallarín and Fernández 2002, 12).

47 Four AC's have their own autonomous police: Canary Islands, Catalonia, the Basque Country, and Navarre. 
Second, the Generalitat saw in the 2000 act a chance to enforce its responsibilities. In July of 2001, "Decret 188/2001" established that Catalonia was in charge of social services (that is, healthcare, education, social assistance, childcare, professional training, and work) to immigrants, even irregular (i.e., illegal) immigrants. The Generalitat underlines in the preamble and in article 9 of this decree that these social services to immigrants are its own jurisdiction (Generalitat de Catalunya 2001a).

Third, "Real Decreto 2393/2004" (Spain's decree) mentions in two places the growing role of AC's in the welcoming of immigrants. First, in its preamble, it focuses on two tasks increasingly taken by AC's: a) information about work conditions; and b) "atención a los inmigrantes" (literally, the taking care of immigrants, a deliberately vague reference to social services). Second, in article 99, AC's can be the ones responsible for modifying work permits for immigrants if they wish (España 2004). The 2000 act was reformed in 2009, as discussed below.

\subsubsection{Secretariat for Immigration (2000) and 2001-2004 Immigration Plan (2000)}

From 2000 onwards, immigration became important in Catalonia. Between 2001 and $2005,90 \%$ of the growth of the population in this AC was due to immigration (ZapataBarrero 2006, 196). In 2000, the Generalitat created the Secretaria per a la Immigració (Secretariat for Immigration), under the Department of the Presidency. In 2001, it approved a new "Pla Interdepartamental d'Immigració 2001-2004” (Interdepartmental Immigration Plan). The novelty of this Plan resides in the "Catalan way of integration," which relies on a balance between diversity and a shared sense of community. Also, in 
this 2001-2004 Plan, the Generalitat contends that the Constitution (art.149.1) is unambiguous in granting the jurisdiction over immigration to the central government for the "nucli essencial de la política immigratòria" - literally, the central core of the immigration policy, that is, the entry and exit of foreigners, their residence and work permits, their numbers, the sanctions, etc. (Generalitat de Catalunya 2001b, 119). However, the Generalitat also claims that it has a role to play in immigration:

"the Generalitat has competences over other fundamental aspects in immigration policy. Thus, the Generalitat has acted and has to act in the future in a significant manner in the social and economic integration of the immigration population, through the sectorial policies in domains of education, hygiene, accommodation, etc." (Generalitat de Catalunya 2001b, 119, author's translation).

To support its claim to act in immigration policy, the Generalitat argues that: a) it has been doing so for two years already; and b) this is in line with the future EU's common immigration policy that strives to make all parts of the society involved in dealing with immigration. The Generalitat requests two things. First, it wants "an active participation in the process of work permits and visas" (Generalitat de Catalunya 2001b, 119-120, author's translation). Second, it wants the "possibility of having civil servants from the Generalitat in consular offices, giving them the mission of welcoming those who wish to come to Catalonia, and explicating the reality of Catalonia and facilitating their hiring prior to arriving" (Generalitat de Catalunya 2001b, 120, author's translation). All these demands would be officially formulated in the 2006 revision of Catalonia's Statute of Autonomy. 


\subsubsection{Revised Statute of Autonomy (2006)}

The Generalitat released a subsequent edition of its Interdepartmental Immigration Plan for 2001-2004: the "Pla de ciutadania i immigració 2005-2008" (literally, the "2005-2008 Citizenship and Immigration Plan"). However, this was not a decisive document for immigration policy in Catalonia. It conceptualized the "language of citizenship" and a common public culture, and it emphasized the contribution of immigrants to Catalonia (Generalitat de Catalunya 2005).

Much more important is, in 2006, the veritable commencement of Catalonia's immigration policy (Zapata-Barrero 2009, 125-161). ${ }^{48}$ In the revised Statute of Autonomy, immigration was framed in terms of Catalonia's needs and constitutional responsibilities. Among these, first on the list, was immigration, over which Catalonia was seeking more control.

In the 2006 document published by the Generalitat to explain the new Statute of Autonomy, the first reason given for its need is: "The adaptation of the [Catalan] institutions to the political and social reality of our times" (Saura 2006, 10, author's translation). And the first example of this contemporary reality is immigration from outside of the EU "which already [composes] over $10 \%$ of the population, a percentage higher than in France, Germany, and Italy, while the Generalitat does not have jurisdiction over it [immigration]" (Saura 2006, 11, author's translation). Indeed, in the revised Statute, Catalonia is to have exclusive jurisdiction over the reception of

48 The political context of the revised version of the Catalan Statute of Autonomy was discussed previously, but it might be worth reminding the broad situation: Catalonia wanted more powers from Madrid. It wrote a revised Statute in collaboration with most political parties in Madrid. This revised Statute was approved by the Catalan Parliament, and, afterwards, by the Catalan population via a referendum. The PP brought it before the Constitutional Court because it thought it violated the Spanish Constitution. The judgment came in 2010. 
immigrants and their integration (Generalitat de Catalunya 2006, art.138.1). Also, Catalonia would have exclusive jurisdiction in terms of foreign workers (Generalitat de Catalunya 2006, art.138.2). Finally, Catalonia would take part in key immigration decisions (Generalitat de Catalunya 2006, art.138.3).

Catalonia bases its new jurisdiction partly on the 2000 act which legalized the social integration of immigrants. According to the 2006 Statute, Catalonia will be in charge of creating a model of integration, of legalizing it, and of making rules to implement it (Generalitat de Catalunya 2009, 51). The Generalitat refers to this package of new responsibilities as a "sous-compétence" in the French version and as a "subsidiary authority" in the English version of the 2009 "Citizenship and Immigration Plan" when discussing it (Generalitat de Catalunya 2009, 51 both versions). This careful wording is in line with the explicit statement that the 2006 legislation does not seek to impede the nuclear competence of Madrid in immigration (Generalitat de Catalunya 2009, 49). Also, Catalonia ascribes another new jurisdiction - the initial reception of immigrants - to the Generalitat and calls it, too, a "sous-compétence" (Generalitat de Catalunya 2009, 52).

Even more important are the work permits. With the 2006 Statute, Catalonia is now responsible for them, as it will be the one responsible for the "initial" granting of work permits. According to the Generalitat, "the assumption of the granting of initial work permits - the great statutory innovation with respect to immigration - is not the only new feature in the field of employment in the Statute, as the new Article 138.2 also shields the powers vested in the autonomous regions by current legislation and regulation" (Generalitat de Catalunya 2009, 53). The Generalitat mentions that Madrid 
remains in charge of employment legislation in general, that is, for criteria of work permits and penalties, yet, Madrid will be obligated henceforth to coordinate with Barcelona (Generalitat de Catalunya 2009, 53-54). As detailed below, Madrid did not respond favorably to Catalonia's demands for more powers in immigration. ${ }^{49}$

\subsubsection{National Agreement on Immigration (2008)}

The 2008 "Pacte Nacional per a la Immigració" (the Generalitat translates it as the "National Agreement on Immigration") purports to fill three tasks: it "a) explains what has happened to us [Catalans]; b) listens to what the people say; c) provides answers" (Generalitat de Catalunya 2008d). These "answers" take the form of three lines of action: management of the workforce (in order to maintain Catalonia's competitiveness); adaptation of the public service to a diverse population; and building of a common sense of the nation (notably through the Catalan language) (Generalitat de Catalunya 2008a, $32-77)$.

Catalonia issued four national agreements between 2006 and 2008 (Generalitat de Catalunya 2008b). In Catalonia, these are probably equivalent to Canadian "white papers," that is, statements of policy changes to come in a specific domain (education, environment, etc.). By issuing a national agreement on immigration, the Catalan government was showing Madrid that it had a social consensus on the question and that it wanted to take action in immigration. The 2008 "National Agreement on Immigration" promotes the Catalan society as being "diverse" and cohesive thanks to a "shared

49 In addition to article 138, article 84 also makes note of immigration. According to it, the forefront assistance of immigrants (that is, the provision of first care social services) will be under the responsibility of municipalities (Generalitat de Catalunya 2006, art.84). This was not dismissed by the Constitutional Court in 2010 (Tribunal Constitucional 2010, II, art.37). 
common project." Its Signature Document (or presentation page) writes: "The consensus involved in the National Agreement on Immigration represents a further step forward after the many great initiatives that have been performed through the local setting and associations, as well as the different Governments of the Generalitat, in order to encourage the management, reception and integration of immigration" (Generalitat de Catalunya 2008a, 7). It emphasizes that the Signature Document is the result of substantial collaboration across the "civil society" that deals with immigrants, and points out that 32 associations have signed it (Generalitat de Catalunya 2008a, 5).

\subsubsection{Citizenship and Immigration Plan (2009)}

In 2009, Catalonia went one step further in its attempt to obtain more powers in immigration from Madrid. Immigration was a growing concern in Catalonia and the Catalan government still did not have power over this policy. Jordi Pujol (an influential leader who was president of the Generalitat from 1980 to 2003) said in 2009: "Le grand problème que nous avons en Catalogne, c'est l'immigration" (Boire and Roy 2009). According to Pujol, Catalonia does not have enough power within Spain to manage immigration, to preserve the Catalan identity (Boire and Roy 2009). The Catalan "Pla de Ciutadania i Immigració 2009-2012" (the English version calls it the "2009-2012 Citizenship and Immigration Plan") concretizes the actions planned in the 2008 "National Agreement on Immigration" and is directly in line with the 2006 Statute of Autonomy (Generalitat de Catalunya 2009, 9-10). This document is akin to a full presentation of the immigration policy of Catalonia: it first investigates data on immigration over time (including learning of Catalan by immigrants); then it details the European, Spanish, and 
Catalan legislation related to immigration since the 1970 's; and finally it presents the 2009-2012 Plan. The full document is detailed (more than 150 pages) and is translated to French, English, Aranese, and Castilian. Clearly, its role is to support the 2006 requests for immigration that were included in the revised Statute of Autonomy.

The Plan explains that the EU has increasing powers in immigration, and member States have fewer. The EU is currently responsible for its external border controls and visas (notably via the Schengen System); for asylum issues (for Ukraine, Moldavia, Belarus, and Tanzania); for establishing the rights of foreigners (via the European Union Agency for Fundamental Rights in Vienna and a future Fundamental Rights Charter in the Lisbon Treaty); and for curbing illegal immigration (in particular, the EU now has a "Return Directive" and a Return Fund $\left.{ }^{50}\right)($ Generalitat de Catalunya 2009, 44-45).

As mentioned above, the objective of the 2009-2012 Plan is to implement the 2008 "National Agreement." Indeed, the actions to be taken are divided into the same three lines as in the 2008 "National Agreement": management of the workforce (in order to maintain its competitiveness), adaptation of public services to a diverse population, and building of a common sense of the nation (Generalitat de Catalunya 2009, 77).$^{51}$ It clearly states that the Secretariat for Immigration will henceforth be in charge of the immigration policy, thus in charge of various bodies related to immigration coordination, management, and participation (Generalitat de Catalunya 2009, 78-84). Among these coordination bodies that work under the Secretariat for Immigration is the Comissió Bilateral Estat-Generalitat (literally, the State-Generalitat Bilateral Commission).

50 For more information, see the press release from the European Parliament (European Parliament 2008).

51 The 2009-2012 Plan details very finely each of the three lines into 17 programs, 131 projects, and 235 actions, all with a calendar, responsible organization, references to the 2008 "National Agreement," strategic objectives, and operational objectives (Generalitat de Catalunya 2009, 87-158). 


\subsubsection{Revised Act on Rights and Liberties of Foreigners in Spain and their Social Integration (2009)}

In 2009, Spain revised its 2000 Act on Rights and Liberties of Foreigners in Spain and their Social Integration. It had to do so for three reasons (España 2009a, art.IV). First, the Constitutional Court had judged that some parts of the 2000 act were not constitutional (notably those impeding immigrants from forming associations or protesting in the streets). Second, the EU had enacted nine directives that affected immigration since 2000 and Spain had to integrate them into its legislation. Third, immigration was growing and Spain had to adapt its management in accordance with this reality.

With this law, Madrid did not reply to Catalonia's growing interest for immigration policy - this would come in 2010 with the judgment by the Constitutional Court on the 2006 revised Statute of Autonomy of Catalonia. Rather, the 2009 act makes some room for the AC's. The act presents the Sectoral Conference on Immigration as a way of "channeling the cooperation between the General Administration of the State and the Autonomous Communities" (España 2009a, art.VII, author's translation). Yet, the 2009 act also reaffirms that Madrid is in charge of the "definition, planning, legislation, and development of the immigration policy" and stipulates ten principles that must guide immigration in all of Spain (España 2009a, art.2 bis, author's translation). AC's are left with the role of "integration" of immigrants (España 2009a, art.2 ter, disp. add.82).

As of Summer 2013, the Sectoral Conference on Immigration has met five times (España 2012b) since its creation in 2008 (España 2012a). ${ }^{52}$ It consists of a reunion of

52 The Sectoral Conference on Immigration has not met in 2013 as of July of 2013: http://www.seap.minhap.gob.es/dms/es/areas/politica autonomica/coop_multilateral_ccaa_ue/Conf_Sec toriales/Documentacion/Conf_Sect_Reuniones/parrafo/2013/conferencias_sectoriales_2013.pdf 
elected officials of the central government and the AC's. The last report by the Sectoral Conference (dated March of 2010) claims that three things happened in the 2010 meeting (España 2010, 36-37). First, an integration fund for immigrants was approved. Second, AC's received information about the 4th European conference of ministers of immigration. Third, AC's received information about the Foro para la Integración Social de los Inmigrantes (literally, the Forum for the Social Integration of Immigrants), an organization, within the Ministry of Work and Social Security of Spain, in charge of the integration of immigrants (España [No date]). In sum, this conference appears to play a role of information, from Madrid to the AC's. This is not where Catalonia can influence immigration policy.

But, Catalonia, ${ }^{53}$ instead of Spain, can, since 2009, be the issuer of the "autorización inicial de trabajo" (literally, initial authorization to work) for immigrants who come as immigrant-workers (España 2009a, art.37,68). Barcelona must apply the rules dictated by Madrid using the "Reglamento de la Ley Orgánica 4/2000" (basically, the by-law that comes out of the 2009 act) (Interview with Maria Le Bolay 2012; Interview with Xavier Bosch 2012) ${ }^{54}$ This is formally stated in the agreement of 2009 between Catalonia and Spain on the "traspaso de funciones y servicios a la Generalitat de Cataluña en materia de inmigración" (literally, the transfer of tasks to the Generalitat in matters related to immigration) (España 2009b). As part of the 2006 revised Statute of Autonomy, Catalonia and Spain meet at the State-Generalitat Bilateral Commission (Generalitat de Catalunya 2006, art.183). One of the five sub-commissions of this

53 I am indebted to Mathilde Maria Le Bolay (Interview with Maria Le Bolay 2012) for making a great part of what I claim in this paragraph (and much more about Spain's immigration policy) clear. All remaining errors are mine only.

54 Available at: http://noticias.juridicas.com/base datos/Admin/lo4-2000.html 
bilateral commission is called the Subcomisión bilateral de cooperación GeneralitatEstado en materia de inmigración: trabajo y residencia de extranjeros (literally, the Bilateral sub-commission of cooperation between the Generalitat and the Central State on matters related to immigration: work and residence of foreigners) (Casas i Rondoní 2011). This sub-commission is responsible for reaching agreements for transfers of tasks to the Generalitat in matters related to immigration. In other words, it has the responsibility for analyzing the initial authorizations to work for immigrants. Afterwards, the Bilateral Commission approves them (Interview with Maria Le Bolay 2012). In the end, Catalonia still has no power over the selection of immigrants.

\subsubsection{Judgment of the Constitutional Court (2010)}

Finally, in 2010, the Constitutional Court handed its judgment of the 2006 revised Statute of Autonomy of Catalonia. It was the coup de grâce of the development of the Catalan immigration policy. The Constitutional Court constrained the interpretation of the 2006 Statute. It decided that article 138 was not unconstitutional as long as "immigration" in the revised Statute was understood without its constitutional meaning; otherwise, it would be infringing the exclusive jurisdiction of Spain as listed in art.149.1.2 of the Constitution. For each of the three parts of art.138 of the new Statute, the Constitutional Court offered a restrictive interpretation. First, it judged that the responsibilities of Catalonia - such as social assistance, culture, public health, and social services - did allow for its involvement in immigration. (In other words, Catalonia was still allowed to provide such services to immigrants.) Second, there was no doubt that foreign workers fell under the sole jurisdiction of Spain. Catalonia would not be allowed to choose 
foreign workers, but it could still apply its own labor laws on its territory. Third, only Spain could decide whether (and, if so, how) Catalonia might be part of any decisionmaking relative to immigration (Tribunal Constitucional 2010, art.83). In sum, all of Catalonia's requests in terms of immigration were rejected outright. The Constitutional Court did not allow for any involvement of Catalonia in what is considered the exclusive jurisdiction of Spain, even though it affects Catalonia's responsibilities (social assistance, culture, public health, and social services).

\subsection{Competing visions of immigration policies}

The high point of the immigration policy of Catalonia is the 2009 "Citizenship and Immigration Plan." In it, the Generalitat clearly describes its lines of action towards immigration, based on a large consultation in 2008 and constitutional requests in 2006 that it hoped would be approved. The demands are similar to those of Québec in the early 1970's: power over visas and immigrant workers.

By contrast, the high point of Spain for immigration policy is the 1978 Constitution, which states that the central government has full jurisdiction over immigration - a wording not negotiable according to the 2010 Constitutional Court's decision over the 2006 Statute of Autonomy. Hence the current competition between Catalonia and Spain over immigration policy. 


\subsubsection{Competition between Barcelona and Madrid in immigration policy}

The following time line lists the actions related to the immigration policy in Catalonia

and Spain since the late 1970's. The definitions of the categories are as described previously. 
Illustration 7: Time Line of Actions in Immigration Policy in Catalonia and Spain

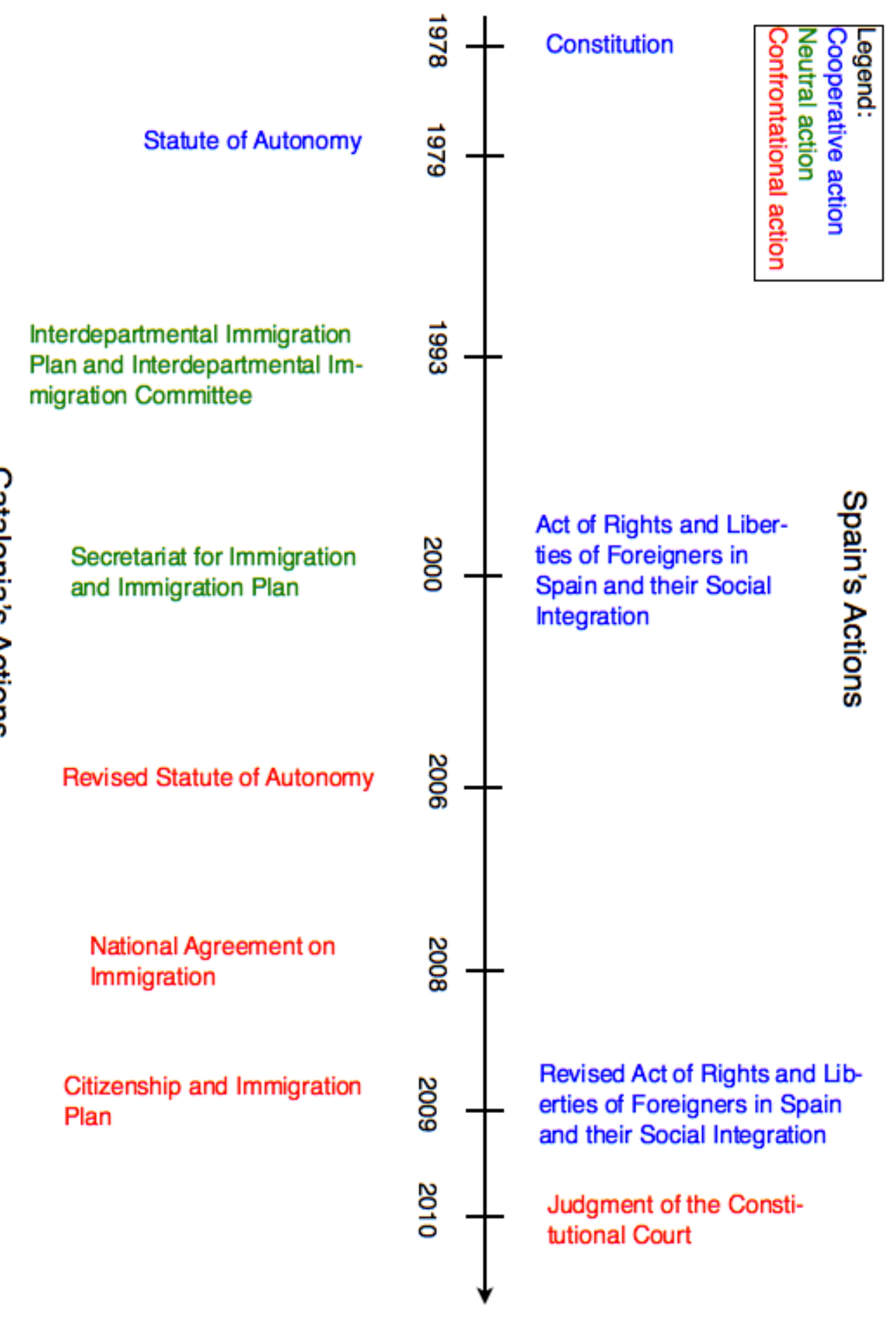


Both governments fully agreed on immigration policy until the 1990's: Madrid was in charge of it. Things changed as immigration became more prevalent, and perhaps, as Catalonia was gaining more powers in other policy domains. In 1993, the Catalan government started expressing concern about immigration on its territory. The Spanish government acquiesced to a few requests in 2000 but, in 2006, when Catalonia revised its entire Statute of Autonomy, the AC clearly wanted to be more officially involved in immigration policy. It did not wait for the Constitutional Court judgment on the 2006 Statute (which, as discussed in a previous chapter, went through many political events before finally being presented in 2010). In 2008, the Generalitat consulted with all immigration stakeholders in Catalonia and implemented programs in 2009. The response of the Constitutional Court in 2010 indicates an unprecedented tension between Madrid and Barcelona over the sharing of immigration policy. This judgment put a serious limit on the ambitions of the Catalan government, notably in terms of immigration policy.

Moreover, as of 2012, Madrid cut all money it was sending back to AC's for the integration of immigrants (EFE 2012). ${ }^{55}$ (In 2004, the Fondo de acogida e integración de personas inmigrantes (literally, the Fund to welcome and integrate immigrant people) was created in order for AC's to integrate immigrants, under the argument that the economic crisis required it.) Surprisingly, Madrid did not diminish the money it sends to NGO's that deal with immigrants (Interview with Xavier Bosch 2012). This makes for a tense situation between Barcelona and Madrid as integration is a Catalan jurisdiction, but Madrid decides how to spend the tax money raised in Spain (Interview with Xavier

55 In case this has not already been made clear in the dissertation, all AC's (except Navarra and the Basque Country) receive almost all of their money from the central state. 
Bosch 2012). (The situation between Madrid and Barcelona is strained these days due to other factors that will be discussed in the concluding chapter of the dissertation, but this is one more factor of tension that is related only to immigration.)

Many of the mentions of AC's in the above description of the immigration policy in Spain refer to all of Spain's AC's - they are not peculiar to Catalonia. However, Catalonia is certainly at the forefront of Spanish AC's demanding more powers in matters of immigration. This is partly due to its considering itself a minority nation. The other part of the explanation is that Catalonia is one of the most economically successful AC's of Spain, thus attracting a good share of the immigration. It is worth noting that in all Catalan documents, there is an emphatic understanding that the immigration that most needs to be dealt with is the non-Spanish, non-Western EU immigration. Most Catalan documents on immigration (e.g. 2001-2004 "Immigration Plan" and 2008 "National Agreement on Immigration") start with a presentation of where immigrants to Catalonia are from - Morocco. And most webpages from the Generalitat that deal with immigration have an obvious clickable icon for "Women." The tension stemming from Muslim immigration - that is, gender equality - is ubiquitous when surveying the Generalitat's information. This perception was confirmed when interviewing the General Director of Immigration of Catalonia: "the Generalitat has an interest for the Islam promoted in Catalonia to be in line with European values" (Interview with Xavier Bosch 2012, author's translation).

This chapter has not detailed the influence of the EU on Spanish immigration policy. Yet, this supra-institution controls a large part of the immigration policy of its 
member countries. According to Ette and Faist, since the late 1970's, there is a "shift of competencies from the national to the European level" $(2007,7)$. This shift intensified with the Amsterdam Treaty in 1997: henceforth, all member countries (including Spain) apply the Schengen Convention of 1985, stipulating that people are free to circulate within the EU (Lavanex 2007, 134-135). ${ }^{56}$ Indeed, "European law on visa and on most asylum and refugee issues is now binding and justifiable and it is superior to national legislation in most of the member states" (Bendel 2007, 33) ${ }^{57}$ The EU also issues "directives" which have to be implemented by member States. To give an example, the "Council Directive 2003/86/EC of 22 September 2003 on the right to family reunification" makes it very clear that polygamy is not recognized (Europa 2011a) ${ }^{58}$ It stipulates: "In the event of a polygamous marriage, where the sponsor already has a spouse living with him in the territory of a Member State, the Member State concerned shall not authorise the family reunification of a further spouse" (European Council 2003, c.II, art.4). Spain, like all other member states, included this in its own legislation (España 2009a, art.16-19). It seems that immigration policy will be more and more decided by the EU in the future (Luedtke et al. 2010, 27). In 2008, the EU members signed a European Pact on Immigration and Asylum that is presented as the "basis for immigration and asylum policies common to the European Union (EU) and its countries" (Europa 2010). The idea is to increasingly harmonize the immigration policies of member states and to curb illegal immigration. A further step was taken in 2011 with the

56 For more on Spain and EU immigration policies, see Fauser (2007).

57 Spain is not one of these countries. For more on the European Parliament's decision process related to immigration, see Bendel (2007).

58 I am grateful to Mathilde Le Bolay (Interview with Maria Le Bolay 2012) for pointing out this example. All remaining errors are mine only. 
"Politique migratoire européenne globale" (no official translation to English) (Europa 2011b).

One element of immigration has been intentionally avoided in this chapter. Since the mid-1990's, Spain and Catalonia have faced a phenomenon of irregular (i.e., illegal) immigration. By definition, the numbers are difficult to agree upon, but most scholars contend that a great share of irregular immigration in Spain goes to Catalonia due to the economic vitality of the AC..$^{59}$ Needless to say, this is a source of tension between Catalonia and Spain, and the meager information does not make the issue any easier to manage.

\subsection{Conclusion}

Québec and Catalonia face a different reality when it comes to immigration policy. The former has a great deal of power over who immigrates to its territory, while the latter has merely the right to welcome and support immigrants, and deal with labour conditions. The lack of constitutional power over immigration for Catalonia does not explain all of its meager capacities in this domain. Indeed, Spain also has all power, according to the Constitution, in foreign relations, yet, over time, Catalonia has come to be entitled with power over "external activity."

In other words, Québec and Canada have a cooperative relationship, while Catalonia and Spain share one full of confrontation. Why? This dissertation argues that Québec sought more powers from Canada incrementally. The Cloutier-Lang Agreement in 1971 gave Québec the right to inform immigrants in Canadian offices. The Bienvenue-

59 For more information on irregular immigration to Spain and Catalonia, see Cornelius (2004). 
Andras Agreeement in 1975 wrote down that immigration was a shared jurisdiction; added that Québec and Ottawa would together plan immigration policy and temporary residence in Québec; and said that they would share information about immigrants, with veto power for Ottawa. Ottawa's Immigration Act in 1976 confirmed that immigration was a shared provincial-federal jurisdiction in practice. The Couture-Cullen Agreement in 1978 stipulated that Québec would be in charge of the criteria for those applying as independent immigrants, temporary workers, students, post-secondary education teachers, and medical-reason tourists. Québec's Immigration Policy in 1990 requested that Québec be in charge of more categories of immigrants and also willingness from Ottawa to maintain the proportion of Francophones in Canada. Finally, in 1991, Québec and Ottawa signed the Gagnon-Tremblay-McDougall Agreement, which still constitutes today the basis of the relationship for dealing with immigrants: the former is in charge of their "selection," while the latter takes care of their "admission." Every time, Ottawa could see that Québec was cooperating: as mentioned earlier, it even officially said so in the agreement of 1975, referring to "increasingly cordial contacts and the growing cooperation" (Bienvenue and Andras 1975, 4-5). By contrast, Catalonia "woke up" in the late 1990 's and wanted everything at once. In 1993, it released an "Interdepartmental Immigration Plan" for 1993-2000; created an Interdepartmental Immigration Committee; and commenced 40 programs to deal with immigration. In 2000, Spain passed the Act on Rights and Liberties of Foreigners in Spain and their Social Integration and gave hope to Catalonia that further action in immigration would be allowed by AC's. It was agreed between Madrid and Barcelona that the Generalitat would be in charge of education and 
social services for immigrants. Later the same year, the Generalitat put up a Secretariat for Immigration and published its 2001-2004 "Immigration Plan." Then, as part of a larger project to gain more powers (the revision of its 1979 Statute of Autonomy), Catalonia planned that it would henceforth have exclusive responsibility over the integration of immigrants and foreign workers; be involved in key immigration decisions, and grant the initial work permits. While the 2006 Statute of Autonomy was being judged before the Constitutional Court, Catalonia gathered relevant civil society's actors and published its consensual "National Agreement on Immigration" in 2008. This was followed by Catalonia's "Citizenship and Immigration Plan" the next year. These two documents express clearly how Catalonia intends to deal with immigration based on three themes. Later in 2009, Spain updated the 2000 act with the passage of the Revised Act on Rights and Liberties of Foreigners in Spain and their Social Integration. It did not respond to Catalonia's increasing requests regarding immigration policy, but instead discussed instances (whose usefulness is not determined) where Barcelona and Madrid met to discuss immigration policy. Then, finally, in 2010, the Constitutional Court released its judgment of the 2006 Statute of Autonomy, ruling out all that Catalonia wanted in terms of immigration policy. Moreover, in 2012, the funds allowed by Madrid to Catalonia for the integration of immigrants were revoked, even though Madrid recognizes that Catalonia is in charge of this. In sum, Catalonia commenced requesting more power in immigration to Spain in the 1990's, just as immigration was becoming significant in Spain (and Catalonia). Right from then, Barcelona requested much from Madrid, and this was met with a blunt refusal from the central government. 
More than the pace of the minority nations' demands is necessary to explain the difference between Québec-Canada and Catalonia-Spain. In the 1970's, Ottawa was alarmed over the possibility of Québec's leaving the federation; Spain does not seem to feel this threat coming from Catalonia, as Madrid has the right to not even recognize referendums on secession (Bozonnet 2009; Europa Press 2009; Gibson 2010).$^{60}$ More importantly, Québec raises its own taxes while Barcelona does very little (Interview with Xavier Bernadí Gil 2012). Nevertheless, this dissertation seeks to explain the relationship based on the actions of the minority and the majority nations' governments, hence the interest here is on how one's actions influence the other's and the incremental pace of Québec's requests for more powers in immigration certainly explains the differential response it received from its majority nation's government from that of Catalonia's.

60 Many referendums were locally organized in Catalonia from 2009 to 2011. The results are available at http://www.decidim.cat/index.php Decidim.cat describes itself as a "Moviment de càrrecs electes locals," that is, a movement of locally elected officials. 


\section{Conclusion of the thesis}

The aim of this dissertation was to fill two gaps in the academic literature. On the one hand, it sought to explain the competition that takes place between a majority nation's and a minority nation's government via public policy. On the other hand, it presented a model that would display this competition and, perhaps, be representative of the situation in other minority nations of industrialized federations, such as Scotland, Flanders, and the Basque Country.

This dissertation has argued that majority nations' governments are more likely to agree to their minority nation's requests for more powers or competences if these demands are presented in an incremental manner. The logic is two-fold. First, the smaller the change in the minority nation's policy, the easier it is for the majority nation to acquiesce to it without changing too much of its own policy or without seeming overly complacent. Second, the more successfully minority and majority nations' governments align as an ensemble, the more likely they appear to continue on this path of success. They gain confidence in one another, or witness the merits (net benefits) of cooperation versus confrontation. Nevertheless, not all policy actions will consist of incremental changes. Confrontation and big steps in policy actions will occur when an issue is brought at the forefront of the policy agenda. Then, the government that faces the policy agenda might think that it has an advantage for a big, non-incremental step or it might think that it does not really have a choice but to do a non-incremental policy action. At other times, there is macro-confrontation between the minority nation's and the majority 
nation's governments.

The rest of this chapter first justifies the comparison of Québec-Canada and Catalonia-Spain. It then summarizes the model developed and the findings of each chapter, that is, of each policy field studied. Finally, it raises a few contemporary issues relevant to the research and discusses future research.

\subsection{Importance of the comparison between Catalonia and Québec}

This dissertation has previously discussed the similarities and differences that justify the comparison of Québec and Catalonia. They find themselves in a similar setting: they display advanced minority nations' institutions and a serious nationalism. Moreover, they both find themselves in industrialized federations. The comparison of Québec-Canada and Catalonia-Spain is important because minority nationalism exists within almost all industrialized federations (except perhaps the U.S.A.). It is a constant source of tension within these countries that, if not managed, can come to represent a serious menace for the political unity of the country. The competition between a minority nation and its respective majority nation matters for the future of countries that face it. Minority nationalism is also important for the legitimacy of majority nations that face it. Even if minority nationalism does not pose an immediate threat to the political unity of a country, morally, any government must seek to represent its population as a whole. If a majority nation does not, over the long term, have the loyalty of a minority nation, its legitimacy is questionable. This dissertation has sought to compare the competition in Québec-Canada 
and Catalonia-Spain that takes place using public policy with the hope of informing the dynamics between minority and majority nations around the industrialized world.

The choice of the two cases studied is attested by the academic literature that already exists, that compares Québec and Catalonia. Keating published Nations against the State (1996) in which he compared Québec, Catalonia, and Scotland based on nationalism, language policy, economy, civil society, and international affairs. He shows that the rise of minority nationalism is a consequence of the increasing "challenges to the State" (e.g., the State has to protect individual rights, to aim for economic prosperity, to keep welfare and social solidarity, to deal with international commitments). Kymlicka published Politics in the Vernacular: Nationalism, Multiculturalism, and Citizenship (2001b) which centered on a discussion of the rights of national minorities such as Québec and Catalonia. He highlighted the inability of federations to include national minorities and discussed the response of national minorities (e.g., Québec and Catalonia). With most of the comparative literature citing these two texts, there is now a wellestablished network of academic students whose research focuses on the comparison of Québec and Catalonia. Alain-G. Gagnon has published many books on the topic, including La raison du plus fort : Plaidoyer pour le fédéralisme multinational (2008) and L'âge des incertitudes : Essais sur le fédéralisme et la diversité nationale (2011), and coedited Nations en quête de reconnaissance : Regards croisés Québec-Catalogne (Gagnon and Requejo 2011). All of these center on the comparison of the cases of Québec and Catalonia. Lecours and Gagnon co-edited Les Nationalismes majoritaires contemporains: identité, mémoire, pouvoir (Nootens, Gagnon, and Lecours 2007), which 
includes chapters on both Spain and Canada. Also, Lecours and Rocher published an article titled "Le fédéralisme comme mode de gestion de la diversité : les cas du Canada et de l'Espagne" (2007) that compares the duality of the central state and its minority nation(s) in the two countries. One could go on and on justifying the interest in the comparison of Québec and Catalonia. Perhaps the most important similarity of QuébecCanada and Catalonia-Spain is the strong sentiment of "being different" that affects most minority residents. It does not matter whether this sentiment is true or not. What counts is the feeling of being a unit, a unit that is not the same as the rest of the country.

The academic literature has focused on the comparison of Québec and Catalonia, as well as other minority nations, but not much their conflict/cooperation over and around public policies. Paquin did compare Québec and Catalonia on the topic of foreign relations in La revanche des petites nations: le Québec, l'Écosse et la Catalogne face à la mondialisation (2001) and La paradiplomatie identitaire: le Québec, la Catalogne et la Flandre en relations internationales (2004). The rest of the existing academic literature has not yet addressed the competition between minority and majority nations via public policy. The dissertation sought to fill in this gap.

\subsection{Overview of the model}

The model developed in the second chapter of this dissertation claims that minority nations' and majority nations' governments compete for the loyalty of their citizens through public policy. Two elements of this assertion are developed below: governments' interest in loyalty and governments' competition via public policy.

First, governments seek the loyalty of their citizens for one main reason: it gives 
them more power to implement policies that are important to them, to which they are dedicated. It is almost a tautology to claim that majority nations' governments do not fear that their language, that their identity will survive in the long term. Because its language, its culture, its identity are the dominant ones in the country that the majority nation governs, it is natural to believe - consciously or not - that these are not endangered and do not need special care to foster in the long term. By contrast, the minority nation's government fears that, in the long term, its language and its identity will not be sustained. This is a problem because parents and grandparents want their descendants to speak their language and share their cultural identity. They might be self-interested and forecast that their descendants' being like them will mean less work on their part when communicating. Or they might be altruistic and consider that their descendants will be more fulfilled if they speak a certain language (theirs) and display a certain cultural identity (theirs, also).

Second, citizens have one main way of assessing their governments, that is, by the actions the governments take, which, together, form a public policy. In turn, governments have one main way of obtaining their citizens' loyalty, that is, by the actions that they take with regard to a public policy. The minority nation's and majority nation's governments thus each have a policy in each field where they can (i.e., language, foreign affairs, and immigration). These actions composing policies may be cooperative, neutral, or confrontational. When they are cooperative, the two governments' policies are aligned with one another. They do not contradict each other, hence citizens can give their loyalty to both governments. When actions are confrontational, the two governments' policies are 
opposed and do not allow citizens to give their loyalty to both governments at the same time in terms of this policy. Neutral actions are either actions of lesser importance or actions that neither align the two governments' policies nor oppose them.

\subsubsection{Hypotheses of the model}

How do these actions play out between the two governments? This dissertation responds by two main hypotheses. The first hypothesis is that the minority nation's and the majority nation's governments respond to one another's actions by implementing similar actions. A government is likely to enact the same type of action as the one to which it is responding. For example, a cooperative action by one government is often responded to by a cooperative action by the other government. In the same vein, a confrontational action from one government generally leads to another confrontational action by the other government. Incremental actions, that is, cooperative or neutral actions, are the best strategy in the long term for a minority nation's government that seeks more power from the majority nation's government. Incrementalism makes the decisions appear less threatening to the majority nation and to other political entities within the country (e.g., provinces or AC's) that might feel unjustly treated when the minority nation obtains more power from the majority nation. Also, the successes of the small changes giving more power to the minority nation encourage changes in the same direction in the future. In the end, the minority nation's government that is in charge of the core elements that differentiate it from the majority nation brings a long-term equilibrium between the two parties. These core elements are related to the long-term prosperity of the minority nation and touch policies that impact language and culture. The long-term situation of the 
language within a minority nation is also determined by immigration, since the proportions of those who assimilate to the minority nation predict the future viability of its language. Also, a minority nation has an interest in defending its interests by itself in the world, without relying on the majority nation's government. By presenting itself as a strong political entity on the international scene, a minority nation shows that it can, if it so decides in the future, become a full country. Hence exist the foreign relations agendas of minority nation's governments.

The second hypothesis of this dissertation relates specifically to one type of action, that is, confrontational ones. Given that confrontation is less fruitful for a minority nation in the long term than incremental actions - which are either cooperative or neutral - one wonders why a government would choose it. This type of competition between the minority nation's and the majority nation's governments occurs for three main reasons. First, a government might perceive the situation as good for advancing a specific policy. In this case, a confrontational action might bring about a bigger change than a smaller action, cooperative or neutral action would. Second, a minority nation's government might also take a leap (big step) in a policy when it thinks that it does not have a choice. When a minority nation's government does not foresee an opening from the majority nation's government in one policy, it might judge it best to simply use confrontation to advance its power in that policy field. And, third, confrontation between the two governments is sometimes quasi inevitable (when incrementalism does not seem possible) and will happen in more than one policy: there is then macro-confrontation between both governments. This is often accompanied by a larger political malaise that 
involves, for example, a serious desire from the minority nation to secede. This dissertation covers three episodes of macro-confrontation, the two referendums in Québec-Canada (in 1980 and 1995) as well as the current situation between Catalonia and Spain.

\subsubsection{Assessment of the model}

Are these hypotheses confirmed by the three policies studied for the cases of QuébecCanada and Catalonia-Spain? Otherwise put, does the theoretical model work? The first hypothesis posits that one government's action is generally responded to by an action from the other government that is of a similar nature. In other words, a neutral action by one government is likely to be followed by a neutral action from the other government and so on for the other two types of actions. Let us verify this hypothesis by briefly examining the three policy fields for each of the two regions studied. The case of linguistic policy in Québec-Canada supports this hypothesis. By simply looking at the time line of actions of Québec and Canada since the 1960's, one notices the similarity of the colors. Blue (cooperative) actions are followed by blue actions in the 1960's, then green (neutral) actions occur in subsequent years (in the early 1970's), and red (confrontational) actions are grouped together in the late 1970's and 1980's. This red ensemble of actions is also explained by the second hypothesis. The competition ends with a green action in 2000. (Notwithstanding the colors, the first hypothesis is also supported by the detail of the actions provided below.) The linguistic policy of CataloniaSpain also corroborates the hypothesis. Blue actions (and one green action) are followed by blue actions until 1992. Actions of 1998 and 2006 constitute exceptions, but are in 
support of the second hypothesis. The actions that compose the foreign policies of Québec-Canada mainly reinforce the first hypothesis. Red actions are responded to by red actions from the 1960's until the late 1990's, until one green action in 2000 leads to another one in 2002, and the competition goes back to cooperation in 2006. (Québec's action of 1985, the Conférence des chefs d'État et de gouvernement des pays ayant en commun l'usage du français, constitutes an exception due to a momentary political détente when Mulroney took power.) In Catalonia-Spain, the study of the competition via the foreign policies of both governments shows blue actions grouped together in the late 1970's. Red actions follow one another in the late 1980's and so do blue actions in the 1990 's and 2000's. The subsequent years correspond to macro-confrontation and are explained by the second hypothesis. The immigration policy in Québec-Canada is fairly simple: it is only composed of blue actions and thus embraces the first hypothesis. Finally, the immigration policy in Catalonia-Spain shows a grouping of blue and green actions up to the year 2000. Afterwards, the competition is relevant to the second hypothesis.

The second hypothesis deals with confrontational actions and macroconfrontation between a minority nation's government and its respective majority nation's government. The linguistic policies in Québec-Canada reflected confrontation in the late 1970's and early 1980's. In 1977, when enacting the Charter of the French Language, Québec thought that it had a favorable momentum to advance its linguistic policy. The PQ had been elected the previous year in Québec's provincial elections and the Premier of Québec, René Lévesque, was a charismatic leader. Then ensued the first episode of 
macro-confrontation between the two governments, illustrated by the 1980 referendum. The two following actions by the federal government, that is, the 1982 Constitution Act and the 1985 Multiculturalism Act, completed the set of confrontational actions. The linguistic policies of Catalonia and Spain have been plagued with confrontation since 1998 when Catalonia enacted the Linguistic Policy Act. Catalonia thought that it had a chance to further its linguistic policy. After all, no action had followed the 1992 "Decree" (neutral action), so perhaps it seemed that the time was ripe to make its linguistic policy more aggressive. Except for the 2001 European Charter for Regional of Minority Languages, the rest is confrontation between Barcelona and Madrid on linguistic policy. (Spain's action of 2001 constitutes an exception to a series of confrontational actions that is due to the influence of the EU on its member states.) In fact, the rest is macroconfrontation between the two governments, as is discussed below. The paroxysm of this macro-confrontation probably lies in the 2010 Constitutional Court's judgment of the 2006 revised Statute of Autonomy of Catalonia. Catalonia sought more powers in many policy fields with the 2006 text, but the more important demands were rejected by the highest tribunal of the country. The foreign policy in Québec-Canada faced confrontation from the 1960's until the 2000's. The beginning of this series of actions, in 1965, was probably, for Québec, that it did not have a choice if it wanted to advance its foreign policy. Indeed, at the time, Ottawa would defend relatively weakly the minority nation's foreign policy on the international scene. There was probably little the province could do to convince Ottawa to promote more intensely its interests internationally, hence the acceptance of Québec to partake in the 1965 agreements with France. The foreign policy 
of Catalonia-Spain displays the macro-confrontation that has been taking place since the mid-2000's. (There was also confrontation in the late 1980's, when Spain thought that it had a clear advantage over Catalonia in terms of foreign policy.) The immigration policy of Québec-Canada shows no confrontation. However, the immigration policy in Catalonia-Spain provides more evidence of the current macro-confrontation that is taking place between the two governments. (Although, the cooperative action in 2009 was not aligned with the judgment of the Constitutional Court that was handed in 2010.)

\subsection{Linguistic policy}

\subsubsection{Québec-Canada}

The actions taken by Québec in the 1960's in terms of linguistic policy were in cooperation with Ottawa's actions. In 1961, Québec held a Commission royale d'enquête sur l'enseignement dans la province de Québec. The recommendation was two-fold: improve the teaching of the French language in Québec and have the government intervene to protect the language, particularly in Montréal. In 1963, Ottawa established the Royal Commission on Bilingualism and Biculturalism. Nationalism was growing in Québec, and the province was envisioning measures to protect French; put simply, the federal government had to show its interest in linguistic policy. The Commission recommended bilingualism of federal institutions, including Ottawa's Parliament, the federal courts, and the federal civil service. In 1967, troubles started in St-Léonard (a district of Montréal), which would epitomize the conflict between French and English languages in the province and spread wider than the region of Montréal, all across the 
province of Québec. In St-Léonard, 90\% of the immigrant (largely Italian) population was choosing the bilingual curriculum for the instruction their children. As a result, most immigrants integrated into the English population and did not master French. In 1968, the School Board decided to offer only French classes. Anglophones and Allophones decried this decision. In 1968, Bill 85 was introduced in Québec; it would allow parents the choice of the language of instruction. Protests of Francophones, and their opposition, that is, immigrant parents, led to the use of the Riot Act in 1969.

In response to what is now called the "Crisis of St-Léonard," two series of concurrent actions related to linguistic policy occurred. One series of these two actions commenced, in 1968, with the provincial government putting in place the Commission of Inquiry on the Situation of the French Language and Linguistic Rights in Québec in order to inquire about measures to be taken to protect the French language and the linguistic rights of minorities. Québec's Premier wanted to wait for the report of the Commission before new language legislation, but tension was so high that he proposed the Act to promote the French Language in Québec in 1969. This law promoted French at work, in the public arena, and made both French and English mandatory at school. Still, parents could choose the main language of schooling and Francophones were displeased with the protection of the language in the province. The Commission's final report was submitted in 1973, recommending that the government make French the official language of Québec, noting that immigrants would not otherwise learn the language. (It would be followed by Québec's Official Language Act in 1974, discussed below.) A concurrent action took place on the federal side. In 1969, Ottawa enacted the Official Languages Act, 
which introduced a new federal policy regarding languages and identity: the federal government would now be the protector of linguistic minorities (English and French) $a$ mari usque ad mare. On top of that, the federal civil service, courts, Parliament, and laws would henceforth be bilingual.

Actions in linguistic policy by Québec and Ottawa were cooperative until the 1970's. The linguistic policies of the minority and the majority nations were aligned. Both governments were going in the same direction: increasing the status of the French language while protecting the choice of language. In Québec, the government promoted French in the workplace and in public while guarding the rights of parents to choose their children's language of instruction. In Ottawa, the government promoted bilingualism while making itself the protector of linguistic minorities. In the 1970's, however, the situation became more neutral than cooperative.

In 1971, Ottawa announced its "Policy of Multiculturalism," whose objective was to dissociate language and culture. The idea of a bilingual and bicultural country, with each language attached to the Francophone or Anglophone culture, was replaced by that of a multicultural country with still two official languages. In other words, one's language would no longer dictate one's feeling of belonging to a specific culture other than the Canadian identity. This was different from the contemporary linguistic policy of Québec, which sought to preserve the French language on the basis of a Francophone's identity. Québec replied to this new federal action in 1977. In 1974, and probably in response to the federal 1969 Official Languages Act, Québec enacted the Official Language Act (Gémar 2008). This legislation made French the official language of the province. Public 
signs had to include French, businesses had to "francisize," French versions of the law were prioritized, and only children who already knew English could attend English schools. These 1971 and 1974 actions were neutral since both actions did not affect the linguistic policy of the other government. Both Québec and Ottawa could keep their linguistic policy as they intended and citizens could still give their loyalty to both governments at the same time.

The late 1970's and early 1980 's are marked by confrontational actions by the two governments in linguistic policy. This said, the late 1970's and early 1980's constitute a period of macro-confrontation between Québec and Ottawa, that is, confrontation in all aspects related to politics and policy. Starting in 1976 with the election of the separatist PQ, Québec's governing political party - and its charismatic leader (also Québec's Premier) René Lévesque - was in confrontation with the promotion of a united Canada under another charismatic character, Canada's Prime Minister Pierre Elliott Trudeau. The macro-confrontation was apparent in the 1980 referendum on sovereignty of Québec, which menaced the continuity of the country. It reached its paroxysm in 1982 with the repatriation of the Canadian Constitution, which was signed by all provinces except Québec during the Nuit des longs couteaux, a moment that epitomized the macroconfrontation between the province and the federal government.

In 1977, Québec enacted the Charter of the French Language. This law made "French the language of Government and the Law, as well as the normal and everyday language of work, instruction, communication, commerce and business" (Québec 1977b, Preamble). More specifically, it required that public signs be in French, that businesses of 
more than 50 employees be "franciséed," that the French version of laws be the official one, and that only children whose parents had been instructed in English in Québec be admitted to public English schools. Multiple court cases over the years weakened some of these provisions. Most notably, in 1982, the federal Charter of the Rights and Freedoms, included in the Constitution Act, partly confronted the Charter of the French Language when stipulating, by and large, that English children from Canada residing in Québec could be instructed in English in Québec (Canada 1982, art.23). Three years later, in 1985, the federal government enacted the Multiculturalism Act, still a confrontational action against Québec's linguistic policy as it was attacking the biculturalism that was until then parallel and in support to bilingualism.

Since the 1990's, the linguistic policies of Québec and Ottawa have not seen tumult; one could say that the situation of linguistic policies is settled between the minority and the majority nations. In 2000, the General Estates on the Situation and Future of the French Language brought little to no turmoil in Québec. This action was neutral given that it did not go against Ottawa's linguistic policy. Nowadays, little confrontation seems to be taking place between Québec and Ottawa. Interviews conducted with the Commissioner of Official Languages of Canada and the former Associate Deputy Minister of the Secrétariat à la politique linguistique du Québec confirmed that the two governments do not interact when it comes to linguistic policy (Interview with Graham Fraser 2012; Interview with Guy Dumas 2012). On December 5 of 2012, the party in power in Québec, the PQ, presented Bill 14 (Act to amend the Charter of the French language, the Charter of human rights and freedoms and other 
legislative provisions) (Gouvernement du Québec 2012a). This bill includes a few modifications for the Charter of the French Language: francisation for smaller enterprises, francisation for enterprises contracted by the government, and stricter access to English public schools (Radio-Canada 2012). These changes are considered minor and are not otherwise discussed in the dissertation.

\subsubsection{Catalonia-Spain}

During the transition to democracy, the majority nation's government, that is, the Spanish central government, was keen on allowing the use of minority nations' languages. The 1978 Spanish Constitution was explicit about allowing co-official languages in AC's that decided to employ them (Cortes Generales de España 1978, art.3). This was a neutral action in terms of linguistic policy.

When Catalonia decided on its Statute of Autonomy in 1979, it used the provision of Madrid's Constitution and made Catalan co-official with Castilian in the AC (Generalitat de Catalunya 1979, art.3). This Catalan action was aligned with Madrid's linguistic policy, hence, cooperative. In the late 1970's, Spain was in transition towards democracy and there was a consensus that minority languages should be promoted. After all, no one wanted to be associated with Franco's prohibition of the teaching of Spain's minority nations' languages. In 1983, Barcelona made a first step to include Catalan in its education program: it enacted the Normalization Law. Catalan became the language of the Catalan civil service and Parliament, was promoted as a means of communication, and more importantly, children had to be able to use both co-official languages at the end of their basic education (but could still choose the language of instruction). This 
legislation still meant that the linguistic policies of Barcelona and Madrid were in line with one another, that they were cooperative. As far as linguistic policy was involved, citizens could display their loyalty to both governments. In 1990, Madrid enacted the Law of the Education System, one more cooperative action. This law's main purpose was to comply with European legislation, but it nonetheless mentioned that AC's would be allowed to decide on extracurricular activities and was thus favorable to education in Catalan in Catalonia. Indeed, in 1992, Barcelona issued the "Decree that establishes the structure of the mandatory education in Catalonia." This decree made Catalan mandatory in schools from age eight and strengthened immersion in Catalan. This angered nonCatalan speakers across the country as epitomized by the editorial titled "Same as Franco, but the other way round" (author's translation) in the newspaper $A B C$ ("Igual que Franco, pero al revés: persecución del castellano en Cataluña" 1993). Many Spaniards felt that the new Catalan decree was imposing a language, just as Franco had imposed Castilian across the country during his dictatorship. The decree was a neutral action: it did not affect Madrid's linguistic policy, but neither did it reinforce it (as a cooperative action would have).

Catalonia decided to go further in 1998 with the Linguistic Policy Act. From then on, contracts would have to be in the language decided by all parties or in the two coofficial languages, students would have to know both languages to obtain their secondary diploma, means of communications would impose requirements of Catalan use, and businesses would offer services in Catalan. This action was a confrontational one as it protected and promoted Catalan, but not Castilian, in the AC. It was going against 
Madrid's linguistic policy of treating both languages equally in the AC; on the contrary, Barcelona thought that Catalan - not Castilian - needed protection. But the 2001 ratification by Spain of the European Charter for Regional or Minority Languages obliged Madrid to partly align its linguistic policy with that of Barcelona. The 2005 and 2008 recommendations of the Committee of Ministers of the Council of Europe were to the effect, inter alia, that federal civil servants and judges posted in Catalonia had to know the language. As such, this was a cooperative action on the part of the Spanish government, which would align its linguistic policy with that of Barcelona.

But Barcelona was hoping that it would be able to take a big leap in protecting its language with the provisions included in the 2006 revision of its Statute of Autonomy. (The 2006 version was weaker than the 2005 one, which was modified to gain approval from the Spanish Congress.) This 2006 version of the 1979 document made Catalan the "preferred" language of the $\mathrm{AC}$, while maintaining Castilian as a co-official language. Henceforth, the Administration of Justice and Spain's governmental offices would provide services in Catalan. This action was going against Madrid's linguistic policy, which was not (at least fully) offering services in Catalan to Catalonia's citizens; thus, it was a confrontational action. And the response was a confrontational one, too. The 2006 Statute was brought before the Constitutional Court by the political party PP and - after occupying the media with new judges' appointments, resignations, and so on - in 2010, the highest tribunal gave an interpretation that nullified most linguistic provisions, including the one making Catalan the "preferred" language of Catalonia. Since then, Catalonia and Spain have been enduring a period of macro-confrontation that extends 
beyond linguistic policy. This is discussed below, but, as an illustration, referendums on sovereignty are being held in various towns, against the recognition of their validity by Madrid. Interviews conducted in Barcelona and at Spain's Embassy in Ottawa confirmed the macro-confrontation currently taking place between the two nations' governments in terms of linguistic policy. The former Director General of the Linguistic Policy of Catalonia said that Madrid has become increasingly belligerent towards Catalonia's linguistic policy, as the language has progressed in the civil society (Interview with Lluís Jou 2012). Deputy Head of Mission in Ottawa claimed that AC's waste money by promoting languages other than Castilian (Interview with Ignacio Sánchez de Lerín García-Ovies 2012). The distrust between the two governments is ubiquitous in CatalanSpanish politics as of Summer 2013. The contents of the discourse coming from the

country's representative who was met - during a scholarly interview involving notetaking and an official form signed agreeing to the interview - seems singular and, one may advance, is but one illustration of the current period of macro-confrontation between the minority and a majority nations' governments.

\subsubsection{Conclusion on linguistic policy}

The core of linguistic policy for both Québec and Catalonia is that neither trusted the majority nation's government to defend their language. Québec could see the assimilation of French Canadians in the rest of Canada in the 1970's; Catalonia fears the erosion of Catalan on its territory as Madrid does not allow for Catalan, the minority nation's language, to receive more protection than Castilian. In both cases, the central government had (or has) not been doing enough to protect the minority nation's language. In both 
cases, the minority nation implemented incremental legislation. In both cases, the federal government agreed, except when the change was relatively large: Ottawa opposed the 1977 Charter of the French language and Madrid opposed the 2006 "preferred language," enclosed in the revised Statute of Autonomy, of Catalan over Castilian.

\subsection{Foreign policy}

\subsubsection{Québec-Canada}

In 1965, Québec signed agreements with France on two occasions. First, it signed an agreement on exchanges related to education. Second, it signed an agreement on cultural exchanges. The significance in these two agreements lies in Ottawa's absence: Québec signed these with France without Canada's involvement. Also in 1965, the Deputy Premier, Paul Gérin-Lajoie, enunciated the doctrine that would guide Québec's foreign policy henceforth: in accordance with the 1937 judgment of the Judicial Committee of the Privy Council, the province is in charge of its jurisdictions, even at the international level. These actions by Québec were not aligned with Ottawa's foreign policy; at the time, provinces' involvement in international relations was slight. The confrontation continued as France arranged for Québec to take part in two international meetings in 1968. In one instance, France engineered Québec's presence - and Canada's absence - at the Conference of the Ministers of Education of French African Countries in Gabon. Ottawa suspended diplomatic relations with Gabon as a form of protest. In another instance, Québec took part in the General Conference of the Francophonie in Paris, announcing its presence to Ottawa only one day before announcing it publicly. The federal government 
responded with a confrontational action in the form of the release of a document titled "Federalism and International Relations" in 1968. Basically, in this, the federal government argued that Ottawa was the only entity in charge of international relations based on Canada being subject to London in this matter (when Canada was a colony) and based on its power of disallowance of provincial laws (which had not been used since 1943 according to Chaput (1975)). In 1970, Québec responded with another confrontational action. France arranged for Québec to have a seat at the ACCT (which is now the OIF). Moreover, two conferences were held in 1970 in order to put in place this international organization and France had Québec invited both times, distinctly from Ottawa. Thus, from 1965 to 1970, confrontation reigned between Ottawa and Québec in terms of foreign policy.

After the macro-confrontation around the election of the separatist PQ in 1976 and the referendum in 1980, there was a détente between the two governments. In 1985, Québec and Ottawa agreed on the participation of the former to meetings of the ACCT. In short, Québec would be present and intervene, depending on the topic, in accordance with a formal agreement signed by the province and the federal government. As an illustration, for economic questions related to Québec's interests, the province could intervene after consultation with the Prime Minister. This was a cooperative action because both the minority and the majority nations could follow their foreign policy in parallel. Québec was allowed to participate in international meetings related to its language, and intervene on questions of importance to the province. Parallel to Québec's foreign policy, Ottawa was still in charge of questions important to its jurisdictions on the international scene 
and did not lose face because it was still present, with Québec, in ACCT gatherings.

In 1995, a new period of macro-confrontation developed as Québec held a referendum on sovereignty-association. Ottawa released "Canada in the World" and angered Québec. In the document, the Canadian education system is referred to as one (even though it is the jurisdiction of provinces) and one of the three objectives is to promote Canadian values and culture (without reference to Québec's distinct culture). This action was a confrontational one as it was against Québec's foreign policy. Québec's Gérin-Lajoie doctrine stated that the province was responsible on the international scene for its own jurisdictions; in "Canada in the World," Ottawa was posing itself as a unique entity on the international arena. Québec responded three times.

In 1999, Québec released a statement titled "Déclaration du gouvernement du Québec concernant la participation aux forums internationaux traitant d'éducation, de langue, de culture et d'identité" which was an explicit response to Ottawa's 1995 "Canada in the World." The statement claimed that Québec should be able to speak for itself in international forums when it was a question of education, culture, and language. This was an action explicitly against Ottawa's foreign policy at the time, thus confrontational. Ottawa wanted to be the promoter of Canadian culture, while Québec wanted to be in charge of its jurisdictions (including culture) on the international scene. Then, in 2000 , Québec enacted the Act respecting the exercise of the fundamental rights and prerogatives of the Québec people and the Québec State that furthered the Gérin-Lajoie doctrine by claiming that a vote at the National Assembly of Québec would be required for international treaties to be binding for Québec when matters were related to the 
province's jurisdictions. Québec enacted another law in 2002 that "establishes a mechanism enabling the National Assembly to approve any important international commitment the Government intends to make either in respect of a Québec international agreement or an international accord pertaining to a matter within the constitutional jurisdiction of Québec" (Québec 2002, Explanatory notes). These last two actions, in 2000 and 2002, are neutral as they did not affect Ottawa's foreign policy. They were incremental in the sense that the 2000 act followed the Gérin-Lajoie doctrine and the 2002 act added a mechanism to formalize the 2000 act. Put differently, both could be predicted.

As a result, in 2006, Ottawa responded with a cooperative action: it allowed Québec to hold a seat in the Canadian Delegation at UNESCO and to intervene in UNESCO meetings thanks to the Agreement between the Government of Canada and the Government of Québec concerning the United Nations Educational, Scientific and Cultural Organization (UNESCO). Perhaps more importantly, Québec has access in real time to UNESCO's documentation, which gives it a strategic advantage to influence Ottawa's position. This was a cooperative action as both governments have influence on one another's foreign policy. Citizens can be loyal to both governments because they agree on foreign policy. Interviews conducted both in Québec and Ottawa illustrated that the foreign policy was not managed as cooperatively in all aspects. On the one hand, on issues related to international organizations, it seems that civil servants of both governments have collaborated intensely since 2006 (Interview with anonymous civil servant employed at the ministère des Relations internationales du Québec 2012). On the 
other hand, on issues related to international trade, it appears that collaboration depends on the country with which discussions are occurring (Interview with Patrick Muzzi 2012; Interview with Randle Wilson 2012).

\subsubsection{Catalonia-Spain}

The 1978 Constitution of Spain stipulated that international relations were the jurisdiction of the federal government. Article 149 is explicit on this point. On top of that, it is supported by articles 93 (Spain is responsible for international treaties) and 97 (foreign policy is Spain's task). This might appear clear-cut, but the foreign policy's responsibility became challenged by some AC's a few years later. This defiance is not surprising: when the Constitution was enacted in the late 1970's, Spain and AC's were minor global actors. For example, Spain's exports in proportion of GDP were as low as $12.7 \%$ to $14.7 \%$ between 1975 and 1980, as compared to $22.1 \%$ to $28.1 \%$ in Canada (OECD 2013). In other words, the country was (politically and economically) more closed off than Canada was. The 1979 Statute of Autonomy of Catalonia was aligned with the Constitution in terms of foreign policy. It stipulated that it would not infringe on Spain's foreign policy. Indeed, it was written that Barcelona would "enforce international treaties and conventions affecting the matters attributed to it according to this Statute" (Generalitat de Catalunya 1979, art.27.3). Also, the Statute stipulated that "The Government of Catalonia will be kept informed of the drafting of the treaties and agreements and of parliamentary bills concerning customs duties involved in matters of specific interest to it" (Generalitat de Catalunya 1979, art.27.5). Thus, the 1979 Catalan Statute was all cooperative with regard to Spain's foreign policy. 
In the late 1980's, however, a few AC's became more active on the international scene. In 1985, Galicia, another AC, signed a communiqué in collaboration with Denmark. This text was brought before the Constitutional Court, which judged in 1989 that it did not respect the Constitution because international relations were the jurisdiction of the central government. Nevertheless, one judge rendered a dissenting opinion, writing that AC's should be able to conduct "international activity" provided they did not affect Spain's foreign policy. Again in 1989, the Constitutional Court had to decide whether movies co-produced by Catalonia and another country could be ascribed the Catalan nationality by Catalonia itself. ${ }^{61}$ The Constitutional Court judged that the nationality of movies was Catalonia's jurisdiction, arguing that not all external relations are "international relations," and thus do not fall within Spain's jurisdiction according to the Constitution. The first of these two 1989 judgments was a confrontational action by Spain towards Catalonia: the federal government's foreign policy was challenging the will of the $\mathrm{AC}$ to be more present on the international scene, that is, to pursue its own foreign policy for questions related to its jurisdictions. The second of these two 1989 judgments was a cooperative action: Madrid's foreign policy would align with Barcelona's foreign policy so that the latter could conduct external relations without violating the Constitution.

The competition between Barcelona and Madrid changed in the 1990's. In 1992, Spain's signature of the Treaty of the $E U$ came into force. This induced the creation of the Agreement that Institutionalizes the Conference on Issues Related to the European Communities (whose acronym is CARCE in Castilian). Put simply, the Treaty of the EU

61 A Catalan nationality favored subsidies for the movies. 
encouraged member states to have regions participate in the negotiation on EU policies related to regions. Spain thus created the CARCE where AC's and Madrid discuss these issues. Another cooperative action happened in 1994, when the Constitutional Court judged that the Basque Country government could be allowed an office in Brussels. The AC had been maintaining this office since 1981, yet in 1988 Madrid protested before the Constitutional Court, arguing that international relations were its jurisdiction. In its judgment, the tribunal distinguished between "international relations" and "external activities." In the end, the Basque Country could keep its office in Brussels, and so could Catalonia. The CARCE was further developed in the 1990's and 2000's. In 1994, a new Agreement planned for more involvement of AC's in Spain's decisions related to the EU. Then, in 1997, the Act that regulates CARCE was enacted which institutionalized and formalized the CARCE. Moreover, AC's were henceforth allowed to participate in the comités of the European Commission that had to do with their jurisdictions. In 2004, a new Agreement on the CARCE was signed between Madrid and AC's. Since then, the CARCE has four (five since 2009) councils that can each partake in a sub-council of the Council of the EU. The AC's take decisions in the CARCE councils and a representative of the AC's delivers them to the EU sub-council that discusses the same issues, although at a European level. Also since the new Agreement of 2004, Spain's AC's have two councillors representing their positions at Spain's Permanent Representation to the EU (whose acronym is REPER). All these actions of the 1990's and 2000's by Madrid were cooperative. The majority nation's government was incrementally giving more apparent power to AC's, including Catalonia, in terms of foreign policy. The EU encouraged a 
stronger voice for regions within member states on issues related with the EU; Spain responded by creating the CARCE. This reunion of AC's and Madrid was first used to inform AC's and moved to include them in five sub-councils of the Council of the EU. Nonetheless, the cooperation between AC's and Madrid that takes place at the CARCE is dependent upon the politicians elected who take part in it (Interview with Débora Miralles Solé 2012).

Since 2006, cooperative actions in terms of foreign policy have come to a halt in Spain. The new Catalan Statute illustrates the current macro-confrontation that describes the relation between Barcelona and Madrid. As mentioned earlier, Catalonia revised its 1979 Statute of Autonomy and enacted it in 2006. As part of the revised Statute, Barcelona made a big step. It wrote that Catalonia would be able to require Spain to sign international treaties that were in its jurisdictions and that Catalonia would participate in international organizations related to its jurisdictions, such as UNESCO. On top of that, the Statute stipulated that Catalonia would have a bilateral commission with Madrid on EU issues. But, in 2010, the Constitutional Court judged that such a bilateral commission would not be binding for Madrid and that Catalonia could not lessen Spain's jurisdiction in international relations. Both actions related to the 2006 Statute are confrontational. In both instances, one government's action challenged the other government's foreign policy. In 2006, Catalonia tried to impose its say in Spain's decisions related to its jurisdictions on EU issues through the creation of a bilateral commission. In 2010, Spain replied by refusing such a growth in Barcelona's influence on its decisions related to foreign policy. 


\subsubsection{Conclusion on foreign policy}

Québec received support from an external power to increase its say in foreign affairs, thanks to France arranging for Québec to be present at international conferences. As for Catalonia, the EU obliged Spain to give an appearance of more say to AC's. Both Québec and Catalonia have generally proceeded in an incremental manner. Québec has succeeded in being internationally present, almost as much as it could wish in international organizations, but perhaps not as much as it would like in international trade, which is mostly managed by the federal government (Interview with anonymous civil servant employed at the ministère des Relations internationales du Québec 2012; Interview with Patrick Muzzi 2012; Interview with Randle Wilson 2012). Catalonia, on the other hand, would like to increase its presence in Spanish decisions that affect its competences, but the current macro-confrontation prevents more power for the $\mathrm{AC}$ in foreign affairs.

\subsection{Immigration policy}

\subsubsection{Québec-Canada}

Contrary to the two other fields of policy studied (language and foreign affairs), immigration offers a case of continuous cooperative actions between Québec and Ottawa. Québec asked for increasing powers in immigration starting in the late 1960's. Every time, the federal government responded positively to Québec's requests.

Québec created its ministère de l'Immigration in 1968. Previously, Québec had a Service de l'Immigration within its ministère des Affaires culturelles. With the Quiet Revolution and a lowering birthrate, the minority nation's government sought to gain 
more powers with regard to the growth (and the language) of its population. Ottawa did not object to giving more powers to Québec in terms of immigration. After all, this was in line with Ottawa's preference for more immigrants in the country. In the announcement of the new ministry in 1968, both governments expressed the wish for more French immigration to Québec. Québec gained two main things. First, it could post representatives in Canadian immigration offices located in French countries. Second, it could promote immigration to Québec to French speakers. This was only a first action of cooperation between the two governments. Québec and Ottawa signed a first agreement on immigration, the Cloutier-Lang Agreement, in 1971. This agreement gave Québec the permission to give information about the province to potential immigrants within federal immigration offices located overseas. This was, essentially, a widening of the 1968 nonformal agreement that allowed Québec to put civil servants in federal immigration offices located in French countries. In 1975, a second agreement was signed, the BienvenueAndras Agreement. The text wrote that Québec and Ottawa would plan immigration policy and temporary residence together. Also, they would work alongside each other in selecting immigrants, although Ottawa could still veto the immigration decisions. Illustrative of the incremental cooperation on immigration policy between both governments, it is officially written in the agreement that the contacts are "increasingly cordial” between Québec and Ottawa (Bienvenue and Andras 1975, 4-5).

In 1976, Ottawa enacted the Immigration Act. This legislation changed Canada's assessment of refugees' applications, in line with the 1967 UN Protocol Relating to the Status of Refugees. Another change was brought by the new legislation: Ottawa would 
consult with provinces on their immigration's objectives and hand a report on these consultations annually to the House. Thus, this was another cooperative action by the federal government toward provincial governments, including Québec. Ottawa was willingly aligning its immigration policy with those of provinces. Indeed, the act wrote that the federal minister could sign agreements with provinces.

Two more agreements between Québec and Ottawa followed. In 1978, the Couture-Cullen Agreement gave more power to Québec in terms of immigration. Henceforth, Québec could decide the criteria for immigrants applying under the categories of independent immigrants, temporary workers, students, post-secondary education teachers, and medical-reason tourists. In 1990, Québec published its Immigration Policy. The province demanded to be able to decide the criteria for other categories of immigrants, in particular, investors, and to have the proportion of Francophones in Canada taken into account when selecting immigrants, so that their demographic weight could be maintained in the country. Finally, in 1991, Québec and Ottawa signed the Gagnon-Tremblay-McDougall Agreement. This last one is still currently in effect and allows Québec to select most of its immigrants, including refugees (family reunification applications are still solely treated by Ottawa). Also, the demographic weight of Québec (and Francophones) would be acknowledged: Québec can welcome up to $5 \%$ more than its population proportion in Canada of immigrants every year. Moreover, Ottawa would give financial compensation to Québec for the integration of its immigrants. Immigration policies of Québec and Ottawa work in a cooperative way. Québec's immigration policy aims at maintaining the proportion of Francophones in the 
province - done by selecting immigrants who are likely to learn the language and being in charge of immigrants' integration through French courses - and ensuring the demographic weight of the province. Ottawa's immigration policy recognizes the minority nation's need for preserving its French identity and the importance of abiding by international norms on refugees and family reunification. Both governments' immigration policies incrementally became aligned from the 1960's to the 1990's and still are aligned nowadays. Under the 1991 Agreement, Québec "selects" most immigrants, parallel to Ottawa "admitting" them. The result is that Québec welcomes the immigrants it deems likely to integrate to the French minority nation, while Ottawa respects its security criteria and its international engagements. An interview with a federal civil servant confirmed that the 1991 Agreement guides all interactions between federal and provincial governments on immigration and that it satisfies both parties (Interview with anonymous civil servant employed at Citizenship and Immigration Canada 2012).

\subsubsection{Catalonia-Spain}

Until the 1990's, there was net emigration from Spain and immigration was not a concern. Thus, it is not surprising that immigration policy was managed in a cooperative manner by Barcelona and Madrid until the country faced net immigration. The 1978 Spanish Constitution identified immigration as the sole responsibility of the central government, that is, Madrid. In parallel, the Statute of Autonomy of Catalonia of 1979 restated Madrid's full jurisdiction over immigration.

The situation changed around the 1990's as Spain became richer and attracted more immigrants, including illegal ones. In 1991, Spain regularized the situation of many 
of these and, as a corollary, raised awareness of the issue. Parts of the civil society in Catalonia requested that the $\mathrm{AC}$ offer support to its immigrants. In response, Barcelona held a Commission for monitoring and coordinating immigration actions and published a 1993-2000 "Interdepartmental Immigration Plan" as well as put in place an Interdepartmental Immigration Committee. Forty programs for schooling, healthcare, and social services were created, geared at immigrants. For Catalonia, the issue covered many policies, as is indicated by its "interdepartmental" character. This was a neutral action because, while it did not affect Madrid's immigration policy in a substantive way, it was not aligned with it. Catalonia was beginning to take care of immigration on its territory.

In 2000, Madrid revised its immigration legislation through the Act of Rights and Liberties of Foreigners in Spain and their Social Integration and mentioned the AC's twice in it. On the one hand, the new legislation said that Madrid would collaborate with AC's via the Sectoral Conference on Immigration, an assembly of representatives of AC's and central governments. On the other hand, the act read that Madrid would take the projections of the AC's into account when deciding on the number of immigrants to be welcomed each year. Catalonia saw the opportunity to expand its powers with regard to immigration. The same year, that is, in 2000, Catalonia established a Secretariat for Immigration and published a 2001-2004 "Interdepartmental Immigration Plan.” With these joint actions, Catalonia claimed its jurisdiction of education, health, and social services for immigrants, which it had already been doing for the past few years. It demanded two more elements of power in terms of immigration. First, it requested to be involved in work permits and visas. Second, Barcelona asked to have representatives of 
the $\mathrm{AC}$ work in Spanish immigration offices overseas to introduce potential immigrants to Catalonia.

In 2006 confrontational actions commenced in immigration policy. As discussed earlier, this period is one of macro-confrontation between Catalonia and Spain, encompassing more than immigration policy. In the 2006 revised Statute of Autonomy, Catalonia planned more control over immigrants arriving on its territory. Catalonia argued that social integration was within its constitutional competence, thus the integration of immigrants was a "sous-compétence" (in the official documentation available in French). It wanted to be in charge of initial work permits and foreign workers, as well as to be involved in key immigration decisions. While the Constitutional Court was analyzing the 2006 document, Catalonia released a "National Agreement on Immigration" in 2008 and "Citizenship and Immigration Plan" in 2009, both presenting its immigration policy under the same three themes, with programs and all details included. The 2008 document was the result of a civil society's consultation and was signed by 32 associations. It presented the three lines of action of Catalan immigration policy: management of the workforce; adaptation of the public service to a diverse population; and building of a common sense of the nation. The 2009 document detailed the implementation of the three themes identified in the 2008 paper. The 2006 Statute, the 2008 "National Agreement," and the 2009 Plan were all confrontational actions. With these, Catalonia was hoping to take a leap to more powers in immigration. After all, Spain had not refrained from its increasing actions in immigration since the 1990's.

In 2009, Spain enacted the Revised Act of Rights and Liberties of Foreigners in 
Spain and their Social Integration. Among other reasons for revising the 2000 act, the EU had published new directives which required Spain to update its immigration legislation. Nevertheless, the 2009 law restated the Sectoral Conference on Immigration as an organization that institutionalizes collaboration between Madrid and the AC's on the topic of immigration. Yet, this Sectoral Conference appears more as a way for Madrid to communicate information to $\mathrm{AC}$ 's than as a discussion forum.

Finally, the judgment of the revised Statute came in 2010. The Court judged that Catalonia could understand its jurisdiction in social services and such as applying to immigration; that it could make decisions relative to foreign workers by applying the Spanish law; and that Spain did not have to take into account Catalonia in its immigration policy. As mentioned previously, the current situation is one of macro-confrontation between Barcelona and Madrid. Catalonia does not have power to select its immigrants, although, since 2009, it has been in charge of processing working permits, following Spanish legislation. Catalonia thus still has no power in terms of immigration, except for processing working permits and integration (Interview with Maria Le Bolay 2012). However, Barcelona relied on the federal Fund to welcome and integrate immigrant people to provide services of integration for immigrants - this fund was abolished in 2012 (Interview with Xavier Bosch 2012).

\subsubsection{Conclusion on immigration policy}

The Québec-Canada management of immigration policy offers an illustration of incrementalism. Contrary to Catalonia, Québec requested more powers from the majority nation's government in terms of immigration in an incremental manner; and Québec 
obtained a more positive response from Canada than Catalonia did from Spain. This is not to say that the way in which the minority nation presents its requests determines entirely the response from the majority nation's government. However, the incremental nature of the requests by the minority nation does seem to be an important variable - and one that the literature had not identified previously.

\subsection{Current macro-confrontation in Catalonia-Spain}

The current period of macro-confrontation in Catalonia-Spain makes the analysis of this dissertation more interesting, but also uncertain. Barcelona has many grievances with Madrid: these were listed in every interview conducted in Catalonia. Below are three that appear important (but may not be in order of importance). First, the fiscal deficit of Catalonia is said to be unfair to Catalans and one of the causes of its debt. Consumption and income taxes levied in Catalonia are not the property of the Generalitat; rather, they are sent to Madrid, which then distributes it via the Fondo de compensación interterritorial (literally, the Fund of interterritorial compensation) (Interview with Paqui Santonja 2012). ${ }^{62}$ According to the current President of Catalonia, Artur Mas, Barcelona sends the equivalent 20 billion USD of tax revenues collected on its territory every year that is, 8 to $9 \%$ of the Catalan GDP - that never come back to the AC ("Entrevista íntegra d'Artur Mas a la CNN" 2012). In other words, Catalans are unhappy to have both a deficit and be sending so much money to Madrid, which then redistributes it among AC's. According to the newspaper La Vanguardia, "all political parties [...] recognize that there exists a financial discrimination for Catalonia" (Barbeta 2012, author's translation).

62 Official information available at:

http://www.mpt.gob.es/es/areas/politica_autonomica/info_ecofin/4asecorelcol/fci.html (España 2011). 
Catalonia is the third highest (AC) contributor to Spain's revenues, yet it is tenth in terms of money it receives (Barbeta 2012; Interview with Paqui Santonja 2012; Interview with Xavier Bernadí Gil 2012). Therefore, Catalans feel that they receive fewer government services than other citizens of Spain (Barbeta 2011). Second, with respect to the 2006 Statute, the central government had recognized its debt of 978 million euros to Catalonia for the years 2008 and 2009 (Interview with Mercè Corretja Torrens 2012; Interview with Xavier Bernadí Gil 2012; León 2012; Pellicer and Noguer 2012). An additional disposition of the 2006 Statute stipulated that, for seven years, investments by Madrid in Catalan infrastructure were to be proportional to the contribution of Catalonia to the GDP of Spain (Generalitat de Catalunya 2006, disp.add.3a). Yet, the central government argues that the current financial crisis does not allow for the reimbursement (García 2012b). Third, the fiscal agreement between Catalonia and Spain, is a great source of frustration for the AC. In July of 2012, the Parliament of Catalonia voted for a fiscal agreement that would create an Agència Tributària de Catalunya (literally, a Taxation Agency of Catalonia) responsible for collecting all government revenues on the territory of the AC and then negotiating with Madrid the share to be sent to the central government (Redacción 2012). It is to be understood that, with the new fiscal agreement, Barcelona would have henceforth much more negotiating power as to how much would be sent to Madrid and, likely, send less money (Coca 2012). The agreement reads: "When determining the Catalan contribution, Catalonia can not lose sight of its fiscal capacity when making its contribution for solidarity [with poorer AC's]. Resources for solidarity must be destined to basic services of the welfare state, taking into account the fiscal effort 
[of Catalonia]" (Parlament de Catalunya 2012, par.4e, author's translation) ${ }^{63}$ However, Spain's President, Mariano Rajoy, rejected the proposed fiscal agreement in September of 2012 and the President of Catalonia, Artur Mas, called for elections (which took place in November) and won 50 seats (García 2012c; Piñol and Cué 2012; Torregrosa 2012). ${ }^{64}$

On top of these three elements of frustration from Catalonia towards Spain, Barcelona does not recognize the full legitimacy of the decision of the Constitutional Court in 2010 with regard to Catalonia's revised Statute of Autonomy. In 2006, the Generalitat of Catalonia passed its revised Statute of Autonomy. The PP brought it before the Constitutional Court of Spain, declaring it partly unconstitutional. During the next several years, before the Constitutional Court handed down its judgment in 2010, numerous events occurred. According to Barcelona, the judgment is spoiled by these events, which are described here.

The Constitutional Court is composed of twelve judges whose mandates are nine years long. Four of the judges are appointed by a three-fifths vote of the House of Deputies; four are appointed by a three-fifths vote of the Senate; two are appointed by the Spanish Government; and two are appointed by the General Council of Judicial Power. Every three years, three new judges are appointed (Tribunal Constitucional 2008). There are usually six judges considered "conservatives" and six others considered "progressives."

In the Fall of 2005, the PP requested to the Constitutional Court that one judge,

63 Author's translation of: “A l'hora de determinar l'aportació catalana, Catalunya no pot perdre posicions respecte a la seva situació en capacitat fiscal un cop feta la contribució a la solidaritat. Els recursos a la solidaritat s'han de destinar als serveis bàsics de l'estat del benestar tenint en compte l'esforç fiscal."

64 The results of the 2012 election in Catalonia are discussed earlier in the dissertation (see footnote 2). 
Pablo Perez Tremps (a "progressive"), be kept away from the judgment on Catalonia's revised Statute of Autonomy. Tremps was Catalan and had published a report on jurisdictional powers in foreign relations for the Catalan government for which he had been paid 6,000 euros (Lázaro 2007). In January of 2006, the Constitutional Court rejected the PP's request. In July of 2006 the PP asked, once more, that judge Tremps be kept from the judgment on Catalonia's revised Statute. One month later, in October of 2006, the Generalitat of Catalonia asked that another judge be removed, Roberto GarcíaCalvo (a "conservative") ("El recorrido del Estatut: un camino lleno de obstáculos" 2009). Barcelona claimed that judge García-Calvo had voted against the rest of the judges earlier in 2006 to the PP's request that the revised Statute be considered a "reform of a statute" instead of a "modification of the Constitution." (If the Constitutional Court had agreed, this would have prevented the Congress from voting the Statute. When the Congress passed the Statute in 2006, the legitimacy of the Statute was enhanced. $)^{65}$ To Catalonia, García-Calvo did not seem impartial when judging the revised Statute.

The decision on whether these two judges could be part of the decision on Catalonia's revised Statute came later in 2006. On November 2 of 2006, the ten judges (all of them but Tremps and García-Calvo) voted to reject the request that García-Calvo be absent from the judgment and to decide another day on the case of Tremps. With García-Calvo reintegrated among the other judges, the vote, on February 7 of 2007, went against Tremps (Agencias 2007). According to El Pais, this was the first expulsion ever of a judge by the Constitutional Court. In return, the Catalan government asked that two

65 Here is a copy of a 2005 statement by the PP that claims so:

http://www.almendron.com/politica/pdf/documentos/spain/doc 0069.pdf 
judges who had published similar reports for the Spanish government be removed, too, from the judgment on the revised Statute of Autonomy, but its demands were rejected (Lázaro 2007). There would be eleven judges assessing the revised Statute, six "conservatives" and five "progressives."

In December of 2007 four other judges were due to be replaced: three "conservatives" (Guillermo Jiménez, Vicente Conde, and Jorge Rodríguez-Zapata) and one "progressive" (María Emilia Casas, also president of the Constitutional Court) (Vázquez 2007). According to the Público, the PP acted so that there could not be an agreement (that is, three-fifths of the House) on who would replace these four judges. In the end, they stayed in place and decided on the revised Statute ("El recorrido del Estatut: un camino lleno de obstáculos” 2009). In 2008, the judge García-Calvo died. The PP and the PSOE still could not agree on a new judge to replace him or the four other judges (EFE 2009). There would be ten judges assessing the revised Statute, four of whom had their mandates expired, and overall five "conservatives" and five "progressives."

On November 26 of 2009, twelve newspapers published an editorial titled "La dignitat de Catalunya" in which they claimed that the Constitutional Court had lost its legitimacy over the judgment of the revised Statute of Autonomy. In 2010, the President of Catalonia, José Montilla, as well as other political parties in Catalonia, signed a petition requesting that the Constitutional Court appoint five new judges before deciding on the revised Statute of Autonomy, but this did not happen (Global News España 2010).

Finally, in July of 2010, the Constitutional Court judged some important parts of the revised Statute of Autonomy as unconstitutional. (These were discussed throughout 
the dissertation.) Overall, Catalans are dissatisfied and claim that the Constitutional Court was not sufficiently impartial to judge on its Statute of Autonomy. Moreover, these events put in question the role of the constitutional frameworks and the role of the courts in managing minority nations' governments. These questions might be the objects of future research.

\subsection{Concluding remarks and future research}

Québec has more power than Catalonia in all policy fields studied. In linguistic policy, Québec essentially enacts its own laws, as long as the Constitution Act is respected. This means that the current legislation is weaker than the initial version of the 1977 Charter, which has been successfully challenged in court; Québec nonetheless controls most of the language in education, a cornerstone of the maintenance of a language. On the contrary, Catalonia's language of education is being challenged as of 2013 and it appears that the 2010 judgment made it clear that Catalan could be a co-official language in Catalonia, but not a "preferred" one. In foreign policy, Québec also has more power than Catalonia. This is most apparent from the former's presence and the latter's absence (disallowed in the 2010 judgment) at UNESCO. Plus, Québec's Gérin-Lajoie doctrine stipulates that the province is in charge of its jurisdictions on the international scene and this was made official in two acts (of the 2000's). Catalonia, on the other hand, has formal power to conduct external activities but is constrained by the 2010 judgment (which stipulates that Spain does not have to take into account Catalonia's views in this policy field) and by the EU decisions in its jurisdictions. In immigration policy, the difference of powers between the two minority nations is startling. While Québec selects many of its immigrants (with 
some exceptions such as family reunification), Catalonia may only process applicants of working permits by following Spain's legislation.

Is the implication of the hypotheses verified: does incrementalism lead to more power for the minority nation in the long term? The examination of the linguistic, foreign, and immigration policies for Québec-Canada and Catalonia-Spain seems to show that, yes, incrementalism does bring more power for the minority nation in the long term. Of course, the sample is not sufficiently large to derive a strong conclusion, but future research on other minority nations might bring more light to this result. Québec used consciously or not - an incremental approach with immigration and foreign policies. It did not with linguistic policy. As for Catalonia, it did not employ incrementalism in any of the three policy fields. After the end of the dictatorship in 1978, the situation of Catalan was weak. The language had been forbidden in public use for many years and, thus, was not thriving in Catalonia. The language and its corollary, the Catalan culture, were revived thanks to public policy and economic success. One may argue that Catalan grew stronger and that Catalonia became economically more powerful at a fast pace, from the late 1970's to the early 1990's. Then, all of sudden (at least compared to Québec), Barcelona wanted public policies that would enhance its linguistic vitality (hence the 1998 Linguistic Policy Act), its foreign affairs, and its control over immigration. Catalonia wanted more power in foreign affairs, but Spain's adhesion to the EU seemed to be paving the way and the CARCE slowly expanded. It wanted more power in immigration policy and created organizations and plans that were not met with much criticism in the rest of Spain. Finally, Catalonia thought it was the time to request 
formally all those increased powers in one document, the 2006 revised Statute of Autonomy, which was, in short, rejected by the Constitutional Court. This dissertation would argue that incrementalism à la québécoise might have proven more fruitful for Catalonia.

Finally, the cases of Québec-Canada and Catalonia-Spain have been presented as distinct units of analysis, but they might not be. There are reasons to believe that Catalonia and Québec influence one another. The website of the ministère des Relations internationales du Québec lists eleven "secteurs" (from health to workforce) on which it collaborates with Catalonia; eight ministerial missions of Québec in Catalonia since 2003; and twelve Catalan ministerial visits in Québec, also since 2003. These relations are based on the entente-cadre between Québec and Catalonia that dates back to 1996 (Gouvernement du Québec 2012b). A convincing example of this cooperation might be the "entente" between the National Assembly of Québec and the Parliament of Catalonia (Assemblée nationale du Québec 2012). The Comité mixte Québec-Catalogne has met at least six times to discuss projects of cooperation between the two governments (Gouvernement du Québec 2012c). What is more, the offices of the Catalan Delegació del Govern als Estats Units (literally, the Government Delegation in the U.S.A.) are a few meters from the Délégation générale du Québec on the $26^{\text {th }}$ floor of the Rockefeller Centre in New York City. ${ }^{66}$ In sum, there appear to be policy transfers between Québec and Catalonia; consequently, the two cases studied might not be independent from one another. They likely influence one another, at least since the late 1990's. Future research will focus on policy transfers between the minority nations of Québec and Catalonia 66 Merci à ma soeur, Laurence Couture Gagnon, de cette information et de la visite des locaux. 
since the late 1990 's. 


\section{Appendix A: List of interviews conducted}

Nineteen interviews were conducted from April to June of 2012; they are listed in alphabetical order in the table below. All interviews were conducted under the Ethics Clearance of Carleton University (project number 12-0987), valid from January 24 to May 31, 2012. One interview (with Blanchet) took place outside of the Ethics Clearance, in June; however, since this was with a member of Parliament, an Ethics Clearance was not required.

All interviews were useful for this dissertation, except for one. I emailed and phoned the ministère de l'Immigration et des Communautés culturelles du Québec for three months (February - May 2012), after which I was granted a 30-minute interview (the minimum it could last according to my Ethics Clearance) with two civil servants who handed me a three-page document in answer to my previously sent questionnaire. These three pages contained only basic information on immigration that could be easily found on the ministry website. During the interview, the two civil servants replied to every question by reading their three pages of answers. Regrettably, contacts with this ministry did not provide useful information for this dissertation. I called and emailed the ministère de l'Immigration et des Communautés culturelles du Québec again in October of 2012 that is, after the election of the PQ, hoping a change of deputy ministers might modify the response - but was once more refused any substantial information.

\begin{tabular}{|c|c|c|c|c|}
\hline Name & Affiliation & & $\begin{array}{l}\text { Date of } \\
\text { interview }\end{array}$ & $\begin{array}{l}\text { Media } \\
\text { intervien }\end{array}$ \\
\hline hous & Citizenship and & Immigration & March 12, 2012 & In person \\
\hline
\end{tabular}




\begin{tabular}{|c|c|c|c|}
\hline & Canada & & \\
\hline Anonymous & $\begin{array}{l}\text { Ministère des Relations } \\
\text { internationales du Québec }\end{array}$ & April 5, 2012 & In person \\
\hline $\begin{array}{l}\text { Anonymous } \\
\text { (two } \\
\text { servants) }\end{array}$ & $\begin{array}{l}\text { Ministère de l'Immigration et } \\
\text { des Communautés culturelles du } \\
\text { Québec }\end{array}$ & May 24, 2012 & In person \\
\hline $\begin{array}{l}\text { Xavier Bernadí } \\
\text { Gil }\end{array}$ & $\begin{array}{l}\text { Catalonia's Director of the } \\
\text { Technical Bureau in support for } \\
\text { transfers and institutional } \\
\text { cooperation }\end{array}$ & May 7, 2012 & In person \\
\hline $\begin{array}{l}\text { Yves-François } \\
\text { Blanchet }\end{array}$ & $\begin{array}{l}\text { Member of the National } \\
\text { Assembly of Québec and Critic } \\
\text { of Immigration in the PQ (in } \\
\text { opposition at the time of the } \\
\text { interview) }\end{array}$ & June 6, 2012 & By phone \\
\hline $\begin{array}{l}\text { Xavier Bosch i } \\
\text { Garcia }\end{array}$ & $\begin{array}{l}\text { General Director of Immigration } \\
\text { of Catalonia }\end{array}$ & May 9, 2012 & In person \\
\hline $\begin{array}{l}\text { Mercè Corretja } \\
\text { Torrens }\end{array}$ & $\begin{array}{l}\text { Director of Research at the } \\
\text { Institute of Autonomic Studies } \\
\text { of Catalonia }\end{array}$ & May 8, 2012 & In person \\
\hline Guy Dumas & $\begin{array}{l}\text { Interim Secretary of the } \\
\text { Secrétariat à la politique } \\
\text { linguistique du Québec from } \\
1990 \text { to } 1995 \text { and Associate } \\
\text { Deputy Minister of the } \\
\text { Secrétariat à la politique } \\
\text { linguistique du Québec from } \\
\text { 2000 to 2008 }\end{array}$ & April 10, 2012 & In person \\
\hline $\begin{array}{l}\text { Enric Fossas } \\
\text { Espadaler }\end{array}$ & $\begin{array}{lll}\text { Member of the Council of } \\
\text { Statutory } \\
\text { Catalonia }\end{array}$ & May 8, 2012 & In person \\
\hline Graham Fraser & $\begin{array}{l}\text { Commissioner of } \text { Official } \\
\text { Languages of Canada }\end{array}$ & March 12, 2012 & In person \\
\hline Lluís Jou & $\begin{array}{l}\text { Director General of the } \\
\text { Linguistic Policy of Catalonia } \\
\text { from } 1996 \text { to } 2003\end{array}$ & March 22, 2012 & By phone \\
\hline $\begin{array}{l}\text { Mathilde Maria } \\
\text { Le Bolay }\end{array}$ & $\begin{array}{l}\text { Sub-director general of } \\
\text { Immigration of Spain }\end{array}$ & May 11, 2012 & In person \\
\hline Débora Miralles & Secretary of External Affairs of & May 8,2012 & In person \\
\hline
\end{tabular}




\begin{tabular}{|c|c|c|c|}
\hline Solé & Catalonia & & \\
\hline Patrick Muzzi & $\begin{array}{l}\text { Director of the Direction de la } \\
\text { politique commerciale du } \\
\text { ministère du Développement } \\
\text { économique, de l'Innovation et } \\
\text { de l'Exportation du Québec }\end{array}$ & April 10, 2012 & In person \\
\hline $\begin{array}{l}\text { Marjolaine } \\
\text { Ricard }\end{array}$ & $\begin{array}{l}\text { Québec Delegate-General at the } \\
\text { Québec Government Office in } \\
\text { Barcelona }\end{array}$ & April 24, 2012 & By phone \\
\hline $\begin{array}{l}\text { Ignacio Sánchez } \\
\text { de Lerín García- } \\
\text { Ovies }\end{array}$ & $\begin{array}{l}\text { Deputy Head of Mission at the } \\
\text { Embassy of Spain }\end{array}$ & March 15, 2012 & In person \\
\hline Paqui Santonja & $\begin{array}{l}\text { Executive or Senior Advisor } \\
\text { (vocal asesora) at the Ministry } \\
\text { of Finances and Public } \\
\text { Administrations of Spain }\end{array}$ & May 10, 2012 & In person \\
\hline Carles Viver & $\begin{array}{l}\text { Director of the Institute of } \\
\text { Autonomic Studies of Catalonia }\end{array}$ & May 8, 2012 & In person \\
\hline Randle Wilson & $\begin{array}{l}\text { Director General of the Canada } \\
\text { Bureau of Foreign Affairs and } \\
\text { International Trade Canada }\end{array}$ & April 13, 2012 & In person \\
\hline
\end{tabular}




\section{Appendix B: Chronologies of Québec-Canada and Catalonia-Spain (accompanying CD for committee members)}

In order to inform the dissertation, two chronologies were developed at an early stage of the research. Given the length of the two documents, chronologies were presented to committee members in an accompanying $\mathrm{CD}$ and are available upon request. 


\section{Bibliography}

Agence de coopération culturelle et technique (ACCT). 1970. Convention portant création de l'ACCT. Niamey (Niger): http://www.francophonie.org/IMG/pdf/acct-textes-fondamentaux-1970convention-et-charte-3.pdf (July 4, 2013).

Agencias. 2007. "El Constitucional acepta la recusación de Pérez Tremps planteada por el PP." El País. http://elpais.com/elpais/2007/02/05/actualidad/1170667027_850215.html (May 21, 2013).

Ajzenstat, Janet. 2007. "Introduction to the 2006 edition." In Lord Durham's Report, Montréal: McGill-Queen's University Press, vii-xxxi.

Akerlof, George A., and Rachel E. Kranton. 2005. "Economics and identity." In Explorations in pragmatic economics [electronic resource] : selected papers of George A. Akerlof (and co-authors), Oxford: Oxford University Press, 67-99.

Aldecoa, Francisco, and Noé Cornago. 2009. "Kingdom of Spain.” In Foreign Relations in Federal Countries, A Global Dialogue on Federalism, Montréal: Forum of Federations and IACFS by McGill-Queen's University Press, 240-268.

Anderson, Benedict. 2006. Imagined Communities. London: Verso.

Arès, Richard. 1967. "Un siècle de vie française en dehors du Québec." Revue d'histoire de l'Amérique française 21(3a): 533-570.

Armora, Esther. 1993. "El «Proceso de normalización» no es una defensa lógica de la llengua catalana sino una agressión a la castellana." $A B C: 72-75$.

Assemblée nationale du Québec. 2012. "Relations bilatérales - Assemblée nationale du Québec.” http://www.assnat.qc.ca/fr/associations/rel-bila.html (July 30, 2012).

Axelrod, Robert M. 1992. Donnant donnant: une théorie du comportement coopératif. Paris: O. Jacob.

Bailey, Benjamin. 2007. "Heteroglossia and boundaries." In Bilingualism: A Social Approach, New York: Palgrave Macmillan, 257-274.

Balthazar, Louis. 2005. "Projection et présence internationale du Québec." In Appartenances, institutions et citoyenneté, Montréal: Wilson \& Lafleur, 77-86.

Barbeta, Jordi. 2010. "Provocación." La Vanguardia. 
http://www.lavanguardia.com/politica/20100710/53961514463/partidos-ysociedad-civil-esperan-una-participacion-historica-en-la-manifestacion-debarcelona-tras.html (October 7, 2010).

. 2011. "Catalunya tiene los impuestos más altos de España." La Vanguardia. http://www.lavanguardia.com/politica/20110213/54114087359/catalunya-tienelos-impuestos-mas-altos-de-espana.html (August 6, 2012).

—. 2012. "Catalunya es la tercera comunidad que más paga." La Vanguardia. http://www.lavanguardia.com/politica/20120724/54328816886/catalunya-terceracomunidad-mas-paga-decima-recibir.html (February 5, 2013).

Béland, Daniel, and André Lecours. 2004. "Nationalisme et protection sociale: une approche comparative." Canadian Public Policy/Analyse de Politiques 30(3): 319-331.

Bélanger, Louis. 2002. "The Domestic Politics of Quebec's Quest for External Distinctiveness." American Review of Canadian Studies 32(2): 195-216.

Bendel, Petra. 2007. "Everything under Control? The European Union's Policies and Politics of Immigration." In The Europeanization of national policies and politics of immigration: between autonomy and the European Union, New York: Palgrave Macmillan, 32-48.

Bernier, Luc. 1996. De Paris à Washington. La politique internationale du Québec. Sainte-Foy: Presses de l'Université du Québec.

—. 2001. "Mulroney's International "Beau Risque": The Golden Age of Québec's Foreign Policy." In Diplomatic Departures: The Conservative Era in Canadian Foreign Policy, 1984 - 93, Vancouver: UBC Press, 128-141.

Bienvenue, Jean, and Robert Andras. 1975. Agreement concerning information, recruitment and selection fo foreign nationals residing outside of Canada for permanent residence or temporary employment in the Province of Québec.

De Boer, Stephen. 2002. "Canadian Provinces, U.S. States and North American Integration: Bench Warmers or Key Players?” IRPP Choices 8(4): 1-24.

Boire, Roger, and Jean-Pierre Roy. 2009. Questions nationales: Québec, Écosse, Catalogne. Montréal: L'oeil fou.

Bozonnet, Jean-Jacques. 2009. "Les nationalistes catalans organisent un "référendum"." Le Monde. http://www.vigile.net/Les-nationalistes-catalans (June 27, 2012).

Breton, Albert, and Robert Wintrobe. 1982. The Logic of Bureaucratic Conduct. Cambridge, UK: Cambridge University Press. 
Breton, Roland. 1996. "The dynamics of ethnolinguistic communities as the central factor in language policy and planning." International journal of the sociology of language (118): 163-179.

Breuilly, John. 2005. "The State and Nationalism." In Understanding Nationalism, éd. Montserrat Guibernau and John Hutchinson. Cambridge: Polity Press, 32-52.

Brossard, Jacques. 1967. L'immigration: Les droits et pouvoirs du Canada et du Québec. Montréal: Presses de l’Université de Montréal.

Brun, Henri. 2006. "Nation québécoise - La motion Harper: un peu mais tout de même pas rien." Le Devoir: B5.

Canada. 1976. Loi concernant l'immigration au Canada.

- 1982. Constitution Act.

_.1985a. Multiculturalism Act.

—. 1985b. Official Languages Act.

Canada. 1971. "Announcement of Implementation of Policy of Multiculturalism within Bilingual Framework." House of Commons Debates.

Casas i Rondoní, Marc. 2011. "La Comisión Bilateral Generalitat-Estado: regulación y actividad práctica." Revista catalana de dret públic (42): 1-20.

Casassas, Jordi, and Òscar Costa Ruibal. 2003. "La política exterior a Catalunya a l'edat contemporània." In Donar protagonisme a Catalunya: Acció internacional $i$ política de relacions exteriors catalana, Barcelona: ECSA, 97-114.

Castellà Andreu, Josep Maria. 2005. "Projection et présence internationales des entités autonomes: Le cas de 1'Espagne." In Appartenances, institutions et citoyenneté, Montréal: Wilson \& Lafleur, 187-206.

Chaput, Roger. 1975. "Le désaveu ou l'annulation des lois provinciales par le gouvernement fédéral." Revue générale de droit 6(2): 305-320.

CIA - The World Factbook. 2011. "Country Comparison: GDP - per capita (PPP)." https://www.cia.gov/library/publications/the-worldfactbook/rankorder/2004rank.html?

countryName $=$ Spain \& countryCode $=$ sp\&regionCode $=$ eur\&rank=43\#sp (August 3, 2012).

Citizenship and Immigration Canada. 2008. "Canadian Multiculturalism: An Inclusive Citizenship." $\quad$ http://www.cic.gc.ca/english/multiculturalism/citizenship.asp 
(Novemebr 29, 2010).

—. 2012. "News Release - Reform of the Interim Federal Health Program ensures fairness, protects public health and safety." http://www.cic.gc.ca/english/department/media/releases/2012/2012-04-25.asp (June 11, 2012).

Citoyenneté et Immigration Canada. 2011. "Document d'information — Quelques faits au sujet de l'immigration au Canada." http://www.cic.gc.ca/francais/ministere/media/documents-info/2011/2011-0627.asp (September 2, 2011).

Coca, Maria Teresa. 2012. "A qué aspira Cataluña con el pacto fiscal." El Mundo. http://www.elmundo.es/elmundo/2012/09/19/barcelona/1348077306.html (February 6, 2013).

Colino, César. 2009. "Constitutional Change Without Constitutional Reform: Spanish Federalism and the Revision of Catalonia's Statute of Autonomy." Publius: The Journal of Federalism 39(2): 262-288.

Colomer, J. M. 2007. Great empires, small nations: the uncertain future of the sovereign state. London: Routledge.

Commission des États généraux sur la situation et l'avenir de la langue française au Québec. 2001. Le français, une langue pour tout le monde. Québec. http://www.spl.gouv.qc.ca/fileadmin/medias/pdf/COM1-021_Rapport_final.pdf (March 18, 2011).

Committee of Experts of the European Charter for Regional or Minority Languages. 2005. "Report of the Committee of Experts on the application of the Charter in Spain (First monitoring cycle)." http://www.coe.int/t/dg4/education/minlang/Report/Default_en.asp\#Spain (January 13, 2011).

- 2008. "Report of the Committee of Experts on the application of the Charter in Spain (Second monitoring cycle)." http://www.coe.int/t/dg4/education/minlang/Report/Default_en.asp\#Spain (January 13, 2011).

Committee of Ministers of the Council of Europe. 2005. "Recommendation $\operatorname{RecChL}(2005) 3$ on the application of the European Charter for Regional or Minority Languages by Spain (First monitoring cycle)." http://www.coe.int/t/dg4/education/minlang/Report/Default_en.asp\#Spain (January 13, 2011).

- 2008. "Recommendation RecChL(2008)5 on the application of the European 
Charter for Regional or Minority Languages by Spain (Second monitoring cycle)." http://www.coe.int/t/dg4/education/minlang/Report/Default_en.asp\#Spain (January 13, 2011).

Comunidad de Madrid. 2004. "Los Acuerdos de la CARCE." Madrid es Europa: Comité de las Regiones. http://www.madrid.org/cs/Satellite? blobcol=urldata\&blobheader=application $\% 2$ Fpdf\&blobheadername $1=$ Contentdisposition \&blobheadername $2=$ cadena\&blobheadervalue $1=$ filename $\% 3$ DParticipacion+de+la+Comundiad+de+Madrid+en+la+CARCE+y+en+1..pdf \&blobheadervalue $2=$ language $\% 3$ Des $\% 26$ site \%3DMPDE\&blobkey=id\&blobtable=MungoBlobs\&blobwhere=1202771963707 \&ssbinary=true (May 6, 2011).

Conversi, Daniele. 2000. The Basques, the Catalans, and Spain: alternative routes to nationalist mobilisation. Reno, Nevada: University of Nevada Paperback Edition.

Cornelius, Wayne A. 2004. "Spain: The Uneasy Transition from Labor Exporter to Labor Importer." In Controlling Immigration. A Global Perspective., Stanford, California: Stanford University Press, 386-429.

Cortes Generales de España. 1978. "Spanish Constitution." http://www.senado.es/constitu_i/index.html (November 30, 2010).

Council of Europe. 1992. European Charter for Regional or Minority Languages. http://conventions.coe.int/Treaty/EN/Treaties/Html/148.htm (July 21, 2009).

Council of the European Union. 2011. "The Council of the European Union." Consilium. http://www.consilium.europa.eu/showPage.aspx?id=242\&lang=en (May 6, 2011).

Cour suprême du Canada. 1988. Ford c. Québec (Procureur général). http://scc.lexum.umontreal.ca/fr/1988/1988rcs2-712/1988rcs2-712.html (July 14, 2010).

Couture Gagnon, Alexandre. 2012. Interview with anonymous civil servant employed at Citizenship and Immigration Canada.

Couture Gagnon, Alexandre. 2012. Interview with anonymous civil servant employed at the ministère des Relations internationales du Québec.

Couture Gagnon, Alexandre. 2012. Interview with Carles Viver.

Couture Gagnon, Alexandre. 2012. Interview with Débora Miralles Solé.

Couture Gagnon, Alexandre. 2012. Interview with Graham Fraser.

Couture Gagnon, Alexandre. 2012. Interview with Guy Dumas. 
Couture Gagnon, Alexandre. 2012. Interview with Ignacio Sánchez de Lerín GarciaOvies.

Couture Gagnon, Alexandre. 2012. Interview with Lluís Jou.

Couture Gagnon, Alexandre. 2012. Interview with Maria Le Bolay.

Couture Gagnon, Alexandre. 2012. Interview with Mercè Corretja Torrens.

Couture Gagnon, Alexandre. 2012. Interview with Paqui Santonja.

Couture Gagnon, Alexandre. 2012. Interview with Patrick Muzzi.

Couture Gagnon, Alexandre. 2012. Interview with Randle Wilson.

Couture Gagnon, Alexandre. 2012. Interview with Xavier Bernadi Gil.

Couture Gagnon, Alexandre. 2012. Interview with Xavier Bosch.

Couture Gagnon, Alexandre. 2012. Interview with Yves-François Blanchet.

Craig, Gerald M. 2007. "Introduction to the 1963 edition." In Lord Durham's Report, Montréal: McGill-Queen's University Press, xxxiii-xlv.

Crameri, K. 2008. Catalonia: national identity and cultural policy, 1980-2003. Cardiff, UK: University of Wales Press.

Daniel, Dominique. 2006. "La politique d'immigration du Québec." In Politiques publiques: le Québec comparé, Québec: Presses de l’Université Laval, 43-70.

Database for the European Charter for Regional or Minority Languages. [No date]. "The European Charter for Regional or Minority Languages - Applied to Catalan in Spain.” http://languagecharter.eokik.hu/AppliedToLanguages_PII\&IIIleast35.htm (January 13, 2011).

Day, Kathleen M., and Stanley L. Winer. 2012. Interregional Migration and Public Policy in Canada: An Empirical Study. Montréal: McGill-Queen's Press.

Dehousse, Renaud. 1991. Fédéralisme et relations internationales. Bruxelles: Bruylant.

Dieckhoff, Alain. 2000. La nation dans tous ses États: les identités nationales en mouvement. Paris: Flammarion.

—. 2007. "Rapprochement et indifférence." In Les Nationalismes majoritaires contemporains: identité, mémoire, pouvoir., Montréal: Québec Amérique.

Directeur général des élections du Québec. 2012. "Élections générales - Le Directeur 
général des élections du Québec (DGEQ).” http://www.electionsquebec.qc.ca/francais/provincial/resultatselectoraux/elections-generales.php? $\mathrm{e}=72 \& \mathrm{~s}=2 \# \mathrm{~s}$ (December 3, 2012).

Dorion, Henri. 2008. "Une toponymie québécoise." In Le français au Québec: 400 ans d'histoire et de vie, Montréal: Fides, 386-7.

Dubreuil, Benoît, and Guillaume Marois. 2011. Le Remède imaginaire: Pourquoi l'immigration ne sauvera pas le Québec. Montréal: Éditions du Boréal.

Dunton, A. Davidson, André Laurendeau, and Jean-Louis Gagnon. 1967. Rapport de la Commission royale d'enquête sur le bilinguisme et le biculturalisme. Ottawa. http://collectionscanada.gc.ca/ourl/res.php?url_ver=Z39.88-2004\&url_tim=201102-08T17\%3A19\%3A44Z\&url_ctx_fmt=info\%3Aofi\%2Ffmt $\% 3$ Akev\%3Amtx $\% 3$ Actx\&rft_dat=1671408\&rfr_id=info\%3Asid\%2Fcollectionscanada.gc.ca \%3Aamicus (February 8, 2011).

Durocher, René. 1969. "Maurice Duplessis et sa conception de l'autonomie provinciale au début de sa carrière politique." Revue d'histoire de l'Amérique française 23(1): $13-34$.

EFE. 2009. "A la espera de sentencia sobre el Estatut para renovar el Constitucional." El Mundo. http://www.elmundo.es/elmundo/2009/07/18/espana/1247934040.html (May 21, 2013).

EFE. 2012. "La Generalitat denuncia que no tendrá presupuesto para políticas de acogida." La Vanguardia. http://www.lavanguardia.com/politica/20120504/54288703987/generalitatdenuncia-no-tendra-presupuesto-politicas-acogida.html (June 19, 2012).

España. 1992a. Acuerdo de institucionalización de la Conferencia para Asuntos Relacionados con las Comunidades Europeas. http://www.cepc.es/rap/Publicaciones/Revistas/5/RIE_020_001_445.pdf (May 10, 2011).

España. 1992b. Ley 30/1992, de 26 de noviembre, de Régimen Jurídico de las Administraciones Públicas y del Procedimiento Administrativo Común. http://noticias.juridicas.com/base_datos/Admin/130-1992.html (May 10, 2011).

1997. Ley 2/1997, de 13 de marzo, por la que se regula la Conferencia de Asuntos Relacionados con las Comunidades Europeas. http://www.mpt.gob.es/areas/politica_autonomica/coop_multilateral_ccaa_ue/cca a_y_ue/Participacion_CCAA_Consejo_Ministros/CARUE/ley_2_1997/document _es/documento.pdf(May 11, 2011).

2000. Ley Orgánica 4/2000, de 11 de enero, sobre derechos y libertades de los 
extranjeros en España y su integración social. http://noticias.juridicas.com/base_datos/Admin/lo4-2000.html (October 31, 2011).

2004. Real Decreto 2393/2004, de 30 de diciembre, por el que se aprueba el Reglamento de la Ley Orgánica 4/2000, de 11 de enero, sobre derechos y libertades de los extranjeros en España y su integración social. (Vigente hasta el 30 de junio de 2011). http://noticias.juridicas.com/base_datos/Derogadas/r5rd2393-2004.html (November 8, 2011).

. 2009a. Ley Orgánica 2/2009, de 11 de diciembre, de reforma de la Ley Orgánica 4/2000, de 11 de enero, sobre derechos y libertades de los extranjeros en España y su integración social.

2009b. Real Decreto 1463/2009, de 18 de septiembre, sobre traspaso de funciones y servicios a la Generalitat de Cataluña en materia de inmigración: autorizaciones iniciales de trabajo por cuenta propia o ajena de los extranjeros cuya relación laboral se desarrolle en Cataluña.

- 2010. Informes sobre la actividad de la Conferencias Sectoriales durante 2010. http://www.seap.minhap.gob.es/dms/es/areas/politica_autonomica/coop_multilate ral_ccaa_ue/cooperacion_multilateral/Conf_Sectoriales/Documentacion/Conf_Se ct_anuales/parrafo/0/text_es_files/INFORME-CONFERENCIAS-

SECTORIALES-2010.pdf (June 19, 2010).

2012a. Conferencias Sectoriales existentes (última actualización abril 2012). http://www.seap.minhap.gob.es/dms/es/areas/politica_autonomica/coop_multilate ral_ccaa_ue/cooperacion_multilateral/Conf_Sectoriales/Documentacion/Conf_Se ct_exist/parrafo/0/01-CONFERENCIAS-REGGIMEN-JURIDICO-ULTIMAMODIFICACION-10-05-

2010/01_CONFERENCIAS_REGIMEN_JURIDICO_ULTIMA_MODIFICACIO N_26-04-2012.pdf (June 19, 2012).

- 2012b. Reuniones de Conferencias Sectoriales. Totales 1981/2012. http://www.seap.minhap.gob.es/dms/es/areas/politica_autonomica/coop_multilate ral_ccaa_ue/cooperacion_multilateral/Conf_Sectoriales/Documentacion/Conf_Se ct_Reuniones/parrafo/81-12/conferencias_sectoriales_1981-2012.pdf (June 19, 2012).

. [No date]. "Foro para la Integración Social de los Inmigrantes." Ministerio de Empleo y Seguridad social. http://extranjeros.empleo.gob.es/es/ForoIntegracion/ (June 19, 2012).

Ette, Andrew, and Thomas Faist. 2007. "The Europeanization of National Policies and Politics of Immigration: Research, Questions and Concepts." In The Europeanization of national policies and politics of immigration: between 
autonomy and the European Union, New York: Palgrave Macmillan, 3-31.

Europa. 2010. "European Pact on Immigration and Asylum." http://europa.eu/legislation_summaries/justice_freedom_security/free_movement _of_persons_asylum_immigration/j10038_en.htm (November 12, 2011).

2011a. $\quad$ "Family $\quad$ reunification." _of_persons_asylum_immigration/133118_en.h̄tm (June 19, 2012).

- 2011b. "Une politique migratoire européenne globale." http://europa.eu/legislation_summaries/justice_freedom_security/free_movement _of_persons_asylum_immigration/j10059_fr.htm (November 12, 2011).

Europa Press. 2009. "Carod replica a Zapatero que las consultas independentistas tendrán efectos "morales"." $L a$ Vanguardia. http://www.lavanguardia.com/politica/20091211/53842940213/carod-replica-azapatero-que-las-consultas-independentistas-tendran-efectos-morales.html (June $27,2012)$.

European Council. 2003. Council Directive 2003/86/EC of 22 September 2003 on the right to family reunification. http://eur-lex.europa.eu/LexUriServ/LexUriServ.do? uri=CELEX:32003L0086:EN:NOT (June 19, 2012).

European Parliament. 2008. "Parliament adopts directive on return of illegal immigrantsPress release." http://www.europarl.europa.eu/sides/getDoc.do? pubRef=-//EP//TEXT+IM-PRESS+20080616IPR31785+0+DOC+XML+V0//EN (June 28, 2012).

Fauser, Margit. 2007. "Selective Europeanization: Europe's Impact on Spanish Migration Control." In The Europeanization of national policies and politics of immigration: between autonomy and the European Union, New York: Palgrave Macmillan, 136-156.

Fishman, Joshua A. 1989. "Language and Nationalism: Two integrative essays, Part II: The impact of nationalism on language and language planning." In Language \& Ethnicity in Minority Sociolinguistic Perspective, Philadelphia: Multilingual Matters Ltd.

Foix, Lluís. 2008. "Culpar al inmigrante." LaVanguardia.com Blogs. http://blogs.lavanguardia.com/lalibreta/culpar-al-inmigrante/ (May 21, 2013).

Fort, Màrius. 2012. "Todas las caras del discurso del miedo." La Vanguardia. http://www.lavanguardia.com/politica/20121004/54352238965/discurso-miedoindependencia-catalunya.html (October 16, 2012). 
Fortin, Pierre. 2010. 'La Révolution tranquille et l'économie : où étions-nous, qu'avonsnous accompli, que nous reste-t-il à faire ?" Conference paper. La Révolution tranquille, 50 ans d'héritages in Montréal, 34. http://www.asdeq.org/ACTIVITES/COMITE-POLITIQUES-

PUBLIQUES/pdf/2010/Txt-membres-du-CPP-Pierre-Fortin-11-mai-2010.pdf (March 14, 2011).

Franco, Alain. 2012. "Bart De Wever, Anvers et contre tous." Le Point. http://www.lepoint.fr/monde/bart-de-wever-anvers-et-contre-tous-15-10-20121517005_24.php (October 16, 2012).

Gagnon, Alain-G. 2008. La raison du plus fort: Plaidoyer pour le fédéralisme multinational. Montréal: Québec Amérique.

—. 2011. L'âge des incertitudes. Essais sur le fédéralisme et la diversité nationale. Québec: Presses de l'Université Laval.

Gagnon, Alain-G., and Ferran Requejo. 2011. Nations en quête de reconnaissance: Regards croisés Québec-Catalogne. Bruxelles: Peter Lang. http://www.peterlang.com/index.cfm? event $=\mathrm{cmp}$. ccc. .seitenstruktur.detailseiten\&seitentyp $=$ produkt $\& \mathrm{pk}=60840 \& \mathrm{cid}=5$ \&concordeid $=21699$ (February 12, 2013).

Gallarín, Juan Antonio Ramos, and Isabel Bazaga Fernández. 2002. "Gestión intergubernamental y política de inmigración en España : el caso de los procesos de regularización de inmigrantes". Conference paper. VII Congreso Internacional del CLAD sobre la Reforma del Estado y de la Administración Pública in Lisbon, Portugal, 21. http://unpan1.un.org/intradoc/groups/public/documents/clad/clad0044411.pdf (June 12, 2012).

García, Luis B. 2012a. "El Gobierno crea un organismo para auditar por completo todas las administraciones." La Languardia. http://www.lavanguardia.com/politica/20121026/54353912188/gobierno-auditaraadministraciones-reducir-duplicidades-competencias.html (November 3, 2012).

_. 2012b. "El Gobierno no incluye en sus presupuestos el pago a Catalunya de la deuda pendiente." La http://www.lavanguardia.com/politica/20120403/54280589338/gobierno-noincluye-cuentas-pago-a-catalunya-759-millones.html (August 6, 2012).

—. 2012c. "Mas entierra el pacto fiscal ante el no de Rajoy." La Vanguardia. http://www.lavanguardia.com/politica/20120920/54350609421/artur-mas-rajoypacto-fiscal-decisiones.html (February 6, 2013).

Garcia Segura, Caterina. 2008. "Les relations internationales de la Catalogne: la 
problématique d'une région européenne dans un État unitaire décentralisé." In L'action extérieure des entités subétatiques: Approche comparée EuropeAmérique du Nord, Louvain: Presses universitaires de Louvain, 145-160.

García Segura, Caterina, and Pablo Pareja Alcaraz. 2003. "Balanç de l'activitat exterior de Catalunya en l'actualitat: marc jurídic i evolució política." In Donar protagonisme a Catalunya: Acció internacional i política de relacions exteriors catalana, Barcelona: ECSA, 115-132.

Gélinas, Xavier. 2007. La droite intellectuelle québécoise et la Révolution tranquille. Québec: Les Presses de l'Université Laval.

Gémar, Jean-Claude. 2008. "Les grandes commissions d'enquête et les premières lois linguistiques." In Le français au Québec: 400 ans d'histoire et de vie, Montréal: Fides, 679.

Generalitat de Catalunya. 1979. Statute of Autonomy of 1979. http://www.gencat.cat/generalitat/eng/estatut1979/index.htm.

1983. Llei de normalització lingüistica a Catalunya.

1992. DECRET 75/1992, de 9 de març - DOGC núm. 1578 - 03/04/1992 (Pàg 2048). http://educacio.gencat.net/extranet/dogc/decret_75_1992.html (18 octobre 2010).

1998. Ley de política lingüistica.

. 2001a. Decret 188/2001, de 26 de juny, dels estrangers i la seva integració social a Catalunya. http://www.upf.edu/sintesi/2001/de188.htm (November 8, 2011).

—. 2001b. "Pla Interdepartamental d'Immigració 2001-2004." http://www20.gencat.cat/docs/dasc/03Ambits

\%20tematics/05Immigracio/03Politiquesplansactuacio/01antecedents/Enllasos/IM MIGR1.pdf (November 9, 2011).

—. 2005. "Pla de ciutadania i immigració 2005-2008." http://www20.gencat.cat/portal/site/bsf/menuitem.7adbc213f0eaaecb1285ea75b0c $0 \mathrm{e} 1 \mathrm{a} 0 /$ ?

vgnextoid $=112127 \mathrm{~d} 17 \mathrm{f0a} 4210 \mathrm{VgnVCM} 1000008 \mathrm{~d} 0 \mathrm{c} 1 \mathrm{e} 0 \mathrm{aRCRD} \&$ vgnextchannel

$=112127 \mathrm{~d} 17 \mathrm{f0a} 4210 \mathrm{VgnVCM} 1000008 \mathrm{~d} 0 \mathrm{c} 1 \mathrm{e} 0 \mathrm{aRCRD} \& \mathrm{vgnextfmt}=$ detall\&conten tid=b51c27e436174210VgnVCM1000008d0c1e0aRCRD\&newLang=ca_ES (November 10, 2011).

—. 2006. Estatut d'autonomia de Catalunya. 
2008a. "An agreement to live together. National Agreement on Immigration." http://www20.gencat.cat/portal/site/bsf/menuitem.6e02226e86d88424e42a63a7b0 $\mathrm{c} 0 \mathrm{e} 1 \mathrm{a} 0 /$ ?

vgnextoid $=2 \mathrm{c} 492 \mathrm{~b} 274 \mathrm{c} 5 \mathrm{a} 4210 \mathrm{VgnVCM} 1000008 \mathrm{~d} 0 \mathrm{c} 1 \mathrm{e} 0 \mathrm{aRCRD} \&$ vgnextchannel $=2 \mathrm{c} 492 \mathrm{~b} 274 \mathrm{c} 5 \mathrm{a} 4210 \mathrm{VgnVCM} 1000008 \mathrm{~d} 0 \mathrm{c} 1 \mathrm{e} 0 \mathrm{aRCRD}($ October 31, 2011).

2008b. "Pacte Nacional per a la Immigració - 19 de desembre de 2008 - 14:00h. Actualitat. Generalitat de Catalunya." http://www10.gencat.cat/gencat/AppJava/cat/actualitat2/2008/81218pactenacional peralaimmigraci.jsp (June 18, 2012).

—. 2008c. "Població segons llengua inicial. Catalunya. 2008." Institut d'Estadística de Catalunya. http://www.idescat.cat/territ/BasicTerr? $\mathrm{TC}=5 \& \mathrm{~V} 0=3 \& \mathrm{~V} 1=3 \& \mathrm{~V} 3=3162 \& \mathrm{~V} 4=3163 \& \mathrm{ALLINFO}=\mathrm{TRUE} \& \mathrm{PARENT}=25 \&$ $\mathrm{CTX}=\mathrm{B}$ (August 6, 2012).

- 2008d. "Press Statement. Summary of the agreement." http://www10.gencat.cat/gencat/binaris/anexpacte_immigra_en_tcm34-89303.pdf (June 18, 2012).

- 2009. Citizenship and Immigration Plan 2009-2012. http://www20.gencat.cat/docs/dasc/03Ambits \%20tematics/05Immigracio/03Politiquesplansactuacio/03placiutadania09_012/01 Presentacio/pla_angles.pdf (October 21, 2009).

. 2010. "Anàlisi del darrer semestre de 2009 | La immigració en xifres | Número 6, juliol de 2010." Butlletí Secretaria per a la Immigració. http://www.gencat.cat/dasc/publica/butlletiIMMI/xifres6/analisi-del-darrersemestre-de-2009.htm (July 26, 2011).

_. 2012a. "Mapa de la representació catalana a l'exterior." Secretaria d'Afers Exteriors.

http://www20.gencat.cat/portal/site/afersexteriors/menuitem.fefd9375278ea189fe a66dfbb0c0e1a0/?

vgnextoid=7d498d1abf450310VgnVCM1000008d0c1e0aRCRD\&vgnextchannel $=7 \mathrm{~d} 498 \mathrm{~d} 1 \mathrm{abf} 450310 \mathrm{VgnVCM} 1000008 \mathrm{~d} 0 \mathrm{c} 1 \mathrm{e} 0 \mathrm{aRCRD} \&$ vgnextfmt=default\#map (August 6, 2012).

—. 2012b. Ple del Parlament, sessió núm. 39.1. http://www.ara.cat/politica/president-Generalitat-Artur-Maspolitica_ARAFIL20120925_0003.pdf(November 2, 2012).

Gérin-Lajoie, Paul. 1965. “Allocution du ministre de l'Éducation, M. Paul Gérin-Lajoie, aux membres du Corps consulaire de Montréal, lundi, le 12 avril à 12 h 30 de l'apr હ̀-midi, 
http://www.mri.gouv.qc.ca/fr/ministere/histoire_ministere/documents_archives/dis cours_gerin_lajoie.pdf(March 28, 2011).

Gibson, Gary. 2010. Spain's Secret Conflict. Endboard Productions. http://vimeo.com/25245089 (June 27, 2012).

Global News España. 2010. "PSOE y PP enfrían la posibilidad de renovar el Constitucional a corto plazo." Noticias de Gipuzkoa. http://www.noticiasdegipuzkoa.com/2010/04/18/politica/estado/psoe-y-ppenfrian-la-posibilidad-de-renovar-el-constitucional-a-corto-plazo (May 21, 2013).

Gouvernement du Canada. 2006. "Communiqués - Premier ministre du Canada." Premier ministre Stephen Harper. http://www.pm.gc.ca/fra/media.asp? category $=1$ \&page $=54$ (November 20, 2012).

Gouvernement du Canada, and Gouvernement du Québec. 1978. Entente entre les gouvernements du Canada et du Québec portant sur la collaboration en matière d'immigration et sur la sélection des ressortissants étrangers qui souhaitent s'établir au Québec à titre permanent ou temporaire.

— 1985. "Entente entre le gouvernement du Quebec et le gouvernement du Canada relative au Sommet francophone." http://www.saic.gouv.qc.ca/publications/Positions/Partie3/Document21.pdf (June $28,2011)$.

- 1991. Canada-Québec Accord relating to Immigration and Temporary Admission of Aliens.

Gouvernement du Québec. 1999. "Déclaration du gouvernement du Québec concernant la participation du Québec aux forums internationaux traitant d'éducation, de langue, de culture et d'identité." http://www.saic.gouv.qc.ca/publications/Positions/Partie3/Document39.pdf (June $28,2011)$.

- 2012a. "Bill $n^{\circ} 14:$ An Act to amend the Charter of the French language, the Charter of human rights and freedoms and other legislative provisions - National Assembly of Québec.” http://www.assnat.qc.ca/en/travaux-parlementaires/projetsloi/projet-loi-14-40-1.html (February 5, 2013).

_. 2012b. "Catalogne - MRI - Ministère des relations internationales." Ministère des Relations internationales du Québec. http://www.mri.gouv.qc.ca/fr/relationsdu-quebec/europe/espagne/catalogne (July 30, 2012).

. 2012c. "Coopération Québec-Catalogne - 7e Réunion du Comité mixte QuébecCatalogne (CMQC)." Ministère des Relations internationales du Québec. http://www.mri.gouv.qc.ca/fr//programmes-et-projets/appel-de-projet/comite- 
quebec-catalogne (July 30, 2012).

Gouvernement du Québec, and Gouvernement du Canada. 2006. "Agreement between the Government of Canada and the Government of Québec concerning the United Nations Educational, Scientific and Cultural Organization (UNESCO)." http://pm.gc.ca/eng/media.asp?id=1153 (May 18, 2011).

Government of Canada. 1995. "Canada in the World: Government Statement." http://www.dfait-maeci.gc.ca/foreign_policy/cnd-world/menu-en.asp (May 14, 2011).

Gozálvez Pérez, Vicente. 1996. "L'immigration étrangère en Espagne (1985-1994)." Revue européenne de migrations internationales 12(1): 11-38.

Harvey, Fernand. 1995. "Le Québec et le Canada français: histoire d'une déchirure.” In Identité et cultures nationales: l'Amérique française en mutation, Sainte-Foy: Les Presses de l'Université Laval, 49-64.

Hastings, Adrian. 1997. The Construction of Nationhood: Ethnicity, Religion and Nationalism. Cambridge: Cambridge University Press.

Hayes, Edward T. 2005. "A Comparative Analysis of the Regulation of State and Provincial Governments in NAFTA and GATT/WTO." Chicago Journal of International Law 5(2): 605-623.

Hirschman, A. O. 1970. Exit, voice, and loyalty: Responses to decline in firms, organizations, and states. Cambridge, MA: Harvard Univ Press.

Hudon, Marie-Ėve, and Lucie Lecomte. 2011. "Bilingualism of Supreme Court Judges." Current and Emerging Issues. 41st Parliament: 28-29.

Immigration et Communautés culturelles du Québec. 2011. Fiche synthèse sur l'immigration et la diversité ethnoculturelle au Québec. http://www.micc.gouv.qc.ca/publications/fr/recherchesstatistiques/FICHE_syn_an2010.pdf (July 26, 2011).

Institut de la statistique du Québec. 2012. "Naissances et taux de natalité, Québec, 19002011."

http://www.stat.gouv.qc.ca/donstat/societe/demographie/naisn_deces/naissance/40 1.htm (April 27, 2012).

Instituto Nacional de Estadística. 2011. "Revisión del Padrón municipal 2011. Datos a nivel nacional, comunidad autónoma y provincia. Población (españoles/extranjeros) por lugar de nacimiento y sexo." http://www.ine.es/jaxi/tabla.do? path $=/$ t20/e245/p04/a2011/10/\&file=00000004.px\&type $=$ pcaxis $\& L=0 \quad$ (June 6, 
2012).

Keating, Michael. 1996. Nations against the State. New York: St. Martin's Press.

- 2004. Plurinational democracy: stateless nations in a post-sovereignty era. Oxford: Oxford University Press.

Kelley, Ninette, and Michael Trebilcock. 1998. The making of the mosaic: a history of Canadian immigration policy. Toronto: University of Toronto Press.

- 2010. The making of the mosaic: a history of Canadian immigration policy. Toronto: University of Toronto Press.

Keohane, Robert Owen, and Joseph S. Nye. 2001. Power and interdependence. New York: Longman.

Kymlicka, Will. 2001a. La citoyenneté multiculturelle: une théorie libérale du droit des minorités. Montréal: Boréal.

- 2001b. Politics in the vernacular: Nationalism, multiculturalism, and citizenship. Oxford: Oxford University Press.

Labelle, Micheline, and François Rocher. 2009. "Immigration, Integration and Citizenship Policies in Canada and Quebec. Tug of War between Competing Societal Projects." In Immigration and self-government of minority nations, Bruxelles: Peter Lang, 57-83.

Lachapelle, Guy. 2007. "Identités, économie et territoire: la mesure des identités au Québec et la Question Moreno." Revue Internationale de Politique Comparee 14(4): 597.

Laforest, Guy. 2007. "Afterword. Lord Durham, French Canada, and Quebec: Remembering the Past, Debating the Future." In Lord Durham's Report, Montréal: McGill-Queen's University Press, 177-203.

Lancaster, Kevin. 1971. Consumer demand: a new approach. New York: Columbia University Press.

Lang, Otto E., and François Cloutier. 1971. "Agreement relative to the presence of orientation officers of the Department of Immigration of Quebec in federal immigration offices outside Canada. Signed in Ottawa by the Minister of Manpower and Immigration of Canada, Otto E. Lang, and the Minister of Immigration of Quebec, François Cloutier, this 18th day of May 1971.”

Laporte, Pierre. 1960. Le vrai visage de Duplessis. Montréal: Les Éditions de l'Homme. 
Laurendeau, André. 1962. "Pour une enquête sur le bilinguisme." Le Devoir: 4.

Lavanex, Sandra. 2007. "The Foreign Policy of European Immigration Control." In Immigration Policy in Europe: The Politics of Control, West European politics series, ed.. Virginie Giraudon and Gallya Lahav. New York: Routledge, 129-150.

Lázaro, Julio M. 2007. "Un año de escaramuzas." El País. http://elpais.com/diario/2007/10/20/espana/1192831204_850215.html (May 21, 2013).

Le Monde.fr and AFP. 2012. "Ecosse : l'accord sur un référendum ouvre la voie à une "décision historique"." Le http://www.lemonde.fr/europe/article/2012/10/15/1-accord-sur-un-referendumouvre-la-voie-a-une-decision-historique-en-ecosse_1775550_3214.html (October 16, 2012).

Leclerc, Jacques. 2008. "Écosse." L'aménagement linguistique dans le monde. http://www.tlfq.ulaval.ca/axl/europe/ecosse.htm (July 21, 2010).

2. 2010a. "Histoire (4): La modernisation du Québec (1960-1981), Le français, langue étatique." L'aménagement linguistique dans le monde. http://www.tlfq.ulaval.ca/axl/francophonie/histfrqc_s4_modernisation.htm (January 21, 2011).

— 2010b. "Les modifications à la Charte de la langue française: Les lois modifiant la Charte." L'aménagement linguistique dans le monde. http://www.tlfq.ulaval.ca/axl/amnord/quebecmodif.htm\#loi_178 (January 24, 2011).

—. 2011. "Les minorités francophones au Canada et les lois anti-françaises." L'aménagement linguistique lans monde. http://www.tlfq.ulaval.ca/axl/amnord/cnd_antifranco.htm (July 8, 2010).

Lecours, André. 2002. "Paradiplomacy: Reflections on the Foreign Policy and International Relations of Regions." International Negotiation 7(1): 91-114.

- 2007. Basque nationalism and the Spanish state. Reno, NV: University of Nevada Press.

—. 2009. "Canada." In Foreign Relations in Federal Countries, A Global Dialogue on Federalism, Montréal: McGill-Queen's University Press, 115-140.

Lecours, André, and Geneviève Nootens. 2007. "Comprendre le nationalisme majoritaire." In Les Nationalismes majoritaires contemporains: identité, mémoire, pouvoir, Montréal: Québec Amérique, 19-45. 
León, Ángel. 2012. "La Generalidad admite que la adicional tercera del Estatuto es papel mojado | Intereconomía | 762400." La Gaceta. http://www.intereconomia.com/noticias-gaceta/cataluna/generalidad-admite-queadicional-tercera-estatuto-papel-mojado-20120420 (February 6, 2013).

Lesage, Gilles. 1968. "Québec fait enquête sur la situation de la langue.” Le Devoir: 1-2.

Lessard, Denis. 2012. "Sondage: l'appui à la souveraineté recule." La Presse. http://www.lapresse.ca/actualites/elections-quebec-2012/201208/31/01-4569904sondage-lappui-a-la-souverainete-recule.php (December 3, 2012).

Lessard, Denis, Martin Croteau, and Vincent Larouche. 2012. "Commissaires anglophones: «inacceptable pour le Québec»." La Presse. http://www.lapresse.ca/actualites/quebec-canada/politiquequebecoise/201203/28/01-4510240-commissaires-anglophones-inacceptablepour-le-quebec.php (June 11, 2012).

Levi, Margaret. 1997. Consent, dissent, and patriotism. Cambridge: Cambridge Univ Press.

Lijphart, Arend. 1977. Democracy in Plural Societies: A Comparative Exploration. New Haven, CT: Yale University Press.

Lindblom, Charles E. 1979. "Still muddling, not yet through." Public Administration Review 39(6): 517-526.

Linteau, Paul-André. 2000. "Un débat historiographique: l'entrée du Québec dans la modernité et la signification de la Révolution tranquille." In La révolution tranquille: 40 ans plus tard: un bilan, Montréal: VLB éditeur, 21-41.

Lozano, Carles. 2011. "Votaciones de investidura y mociones de censura 1979 - ..." Història electoral. http://www.historiaelectoral.com/inv.html (November 25, 2012).

Luedtke, Adam, Carrie Humphreys, Terri E. Givens, and Rhonda Evans Case. 2010. "Introduction: Regulating the New Face of Europe." In Migrants and Minorities: The European Response, ed. Adam Luedtke. Newcastle upon Tyne, UK: Cambridge Scholars Publishing, 2-36.

Maalouf, Amin. 1998. Les Identités meurtrières. Paris: Grasset \& Fasquelle.

Malloy, Tove H. 2005. National minority rights in Europe. Oxford: Oxford University Press.

Malone, Christopher. 2011. Les négociations Canada-Union européenne en vue de la conclusion d'un nouvel accord: une démarche difficile. Québec: Laboratoire 
d'étude sur les politqiues publiques et la mondialisation, École nationale d'administration publique. http://www.leppm.enap.ca/leppm/1089/economie.enap (December 16, 2012).

Mar-Molinero, Clare. 2000. The politics of language in the Spanish-speaking world: from colonisation to globalisation. New York: Routledge.

Marín, Manuel. 2010. "Cataluña no es «nación»." $A B C$. http://www.abc.es/20100628/espana/cataluna-nacion-201006282051.html (November 20, 2012).

Martin, Paul. 1968. Federalism and International Relations. Ottawa: Queen's Printer and Controller of Stationery.

May, Stephen. 2008. Language and minority rights: ethnicity, nationalism and the politics of language. New York: Routledge.

McColl Millar, Robert. 2005. Language, nation and power: an introduction. New York: Palgrave Macmillan.

Michaud, Félix-Antoine D., Marie-Andrée Plante, and Patrick Taillon. 2012. "Indépendance - Quand le Royaume-Uni donne une leçon au Canada." Le Devoir. http://www.ledevoir.com/politique/canada/362756/quand-le-royaume-uni-fait-lalecon-au-canada (November 13, 2012).

Michaud, Nelson. 2006. "La doctrine Gérin-Lajoie." In Histoire des relations internationales du Québec, Montréal: VLB éditeur, 263-277.

Ministère de l'Immigration et Communautés culturelles du Québec. 2008. "Pour enrichir le Québec - Affirmer les valeurs communes de la société québécoise." http://www.micc.gouv.qc.ca/publications/fr/mesures/Mesures-ValeursCommunesBrochure2008.pdf (November 29, 2010).

Ministère des affaires fédérales-provinciales du Québec. 1966. Rapport pour l'année se terminant le $31 \quad 1966$. http://www.mri.gouv.qc.ca/fr/ministere/histoire_ministere/documents_archives/ra pport_annuel_1965_1966_final.pdf (May 14, 2011).

Ministère des Communautés culturelles et de l'Immigration du Québec. 1991. Au Québec pour bâtir ensemble, Énoncé de politique en matière d'immigration et d'intégration. http://www.micc.gouv.qc.ca/publications/fr/ministere/Enoncepolitique-immigration-integration-Quebec 1991.pdf (November 29, 2010).

Ministère des Relations internationales du Québec. 2005. "Québec in International Forums: Exercising Québec's constitutional rights at international organizations and conferences." Québec's International Initiatives (1): 8. 
2006. "Legal and Historical Foundations.” Québec's International Initiatives (2): 5.

- 2009. "Québec-Canada agreement on UNESCO." http://www.mri.gouv.qc.ca/en/relations_quebec/organisations_internationales/une sco.asp (May 18, 2011).

—. 2012. "Offices abroad." http://www.mri.gouv.qc.ca/en/ministere/representationetranger/ (August 6, 2012).

Ministerio de Administraciones públicas de España. 2005. Resolución de 28 de febrero de 2005, de la Secretaría de Estado de Cooperación Territorial, por la que se ordena la publicación de los Acuerdos de 9 de diciembre de 2004, de la Conferencia para Asuntos Relacionados con las Comunidades Europeas. http://www.es-ue.org/Documents/organizacionasuntosautonomicosreper.pdf (May $10,2011)$.

Ministerio de Política Territorial y Administración Pública de España. 2010. «Conferencia para Asuntos Relacionados con la Unión Europea ». Ministerio de Política Territorial y Administración Pública. http://www.mpt.gob.es/areas/politica_autonomica/coop_multilateral_ccaa_ue/cca a_y_ue/Participacion_CCAA_Consejo_Ministros/CARUE (May 11, 2011).

Moreno, Luis. 2001. The federalization of Spain. Portland, OR: Routledge.

Morin, Jacques-Yvan, Francis Rigaldies, and Daniel Turp. 1988. Tome II. Droit international public: notes et documents. Montréal: Éditions Thémis.

[Multiple authors]. 1992. Treaty on European Union. http://eurlex.europa.eu/en/treaties/dat/11992M/htm/11992M.html\#0001000001 (May 10, 2011).

[Multiple authors]. 2009. "La dignidad de Catalunya." La Vanguardia. http://www.lavanguardia.com/politica/20091126/53831123016/la-dignidad-decatalunya.html (August 29, 2012).

Nagel, Klaus-Jürgen. 2011. "Le nationalisme catalan et l'Europe." In Nations en quête de reconnaissance. Regards croisés Québec-Catalogne, Diversitas, Bruxelles: Peter Lang, 175-200.

[No name]. 1968. Le Québec se dote d'un ministère de l'Immigration. http://archives.radio-canada.ca/politique/provincial_territorial/clips/12445/ (April 27, 2012).

[No name]. 1993. "Igual que Franco, pero al revés: persecución del castellano en Cataluña." $A B C: 1$. 
[No name]. 2009. "El recorrido del Estatut: un camino lleno de obstáculos." Público. http://www.publico.es/espana/247017/el-recorrido-del-estatut-un-camino-llenode-obstaculos (May 21, 2013).

[No name]. 2010. "El Constitucional rechaza la nación catalana y equipara el castellano al catalán como lengua vehicular en la enseñanza." La Vanguardia. http://www.lavanguardia.com/politica/20100709/53961420416/el-constitucionalrechaza-la-nacion-catalana-y-equipara-el-castellano-al-catalan-como-lenguavehicul.html (December 4, 2010).

[No name]. 2010. "El TC dice que la bilateralidad no significa relación entre iguales y no afecta a competencias estatales." La Vanguardia. http://www.lavanguardia.com/politica/noticias/20100709/53961450120/el-tc-diceque-la-bilateralidad-no-significa-relacion-entre-iguales-y-no-afecta-acompetencias-estat.html (May 18, 2011).

[No name]. 2012. "Entrevista íntegra d'Artur Mas a la CNN." 2012. Quest Means Business. http://www.tv3.cat/videos/4144150/Entrevista-integra-dArtur-Mas-a-laCNN (July 30, 2012).

[No name]. 2012. "Umbrage in Catalonia. Even though the spectre of secession is an unwelcome distraction, Spain still needs to change." The Economist.

[No name]. 2012. "Un coronel del Ejército: “¿La independencia de Catalunya? Por encima de mi cadáver"." La Vanguardia. http://www.lavanguardia.com/politica/20120831/54344065618/coronel-ejercitoindependencia-catalunya-cadaver.html (November 3, 2012).

Nootens, Geneviève, Alain-G. Gagnon, and André Lecours. 2007. Les nationalismes majoritaires contemporains: identité, mémoire, pouvoir. Montréal: Québec Amérique.

Nossal, K. R., S. Roussel, and Stéphane Paquin. 2007. Politique internationale et défense au Canada et au Québec. Montréal: Les Presses de l'Université de Montréal.

OECD. 2013. "OECD Statistics - Country statistical profiles." OECD Stat Extracts. http://stats.oecd.org/Index.aspx?lang=fr\&SubSessionId=567ee912-51bb-4a29bb79-516daf797efe (February 22, 2013).

Organisation internationale de la Francophonie. 2005. Charte de la Francophonie adoptée par la Conférence ministérielle de la Francophonie à Antananarivo. Antananaviro (Madagascar):

OIF. http://www.francophonie.org/IMG/pdf/charte_francophonie.pdf (June 28, 2011).

Paillé, Michel. 2002. "L'enseignement en français au primaire et au secondaire pour les enfants d'immigrants: un dénombrement démographique." Revue 
d'aménagement linguistique Automne 2002(Hors série): 51-66.

Pal, Leslie A. 1995a. Interests of state: The politics of language, multiculturalism, and feminism in Canada. Montréal: McGill-Queens University Press.

—. 1995b. "Language, Policy and Rights in Canada: Pragmatism v. Politics." International Issues 38(6): 38-55.

- 2009. Beyond Policy Analysis: Public Issue Management in Turbulent Times. Toronto: Nelson Education.

Paquin, Stéphane. 2001. La revanche des petites nations: le Québec, l'Écosse et la Catalogne face à la mondialisation. Montréal: VLB éditeur.

- 2003. Paradiplomatie identitaire en Catalogne. Québec: Presses de l'Université Laval.

—. 2004. "La paradiplomatie identitaire: le Québec, la Catalogne et la Flandre en relations internationales." Politique et Sociétés 23(2-3): 203-237.

— 2006a. "La relation Québec-Paris-Otawa et l'Agence de coopération culturelle et technique." In Histoire des relations internationales du Québec, Montréal: VLB éditeur, 62-74.

. 2006b. "La relation Québec-Paris-Ottawa et la création de l'Organisation de la Francophonie (1960-2005)." Guerres mondiales et conflits contemporains 3(223): $31-47$.

—. 2006c. "Le fédéralisme et les relations internationales au Canada: l'inévitable construction d'une diplomatie à paliers multiples?" In Les relations internationales du Québec depuis la Doctrine Gérin-Lajoie (1965-2005): le prolongement externe des compétences internes, Québec: Presses de l'Université Laval, 23-47.

— . 2008. "Paradiplomatie identitaire au Québec." In L'action extérieure des entités subétatiques: Approche comparée Europe-Amérique du Nord, ed. Françoise Massart-Piérard. Louvain: Presses universitaires de Louvain, 67-82.

Paquin, Stéphane, and Louise Beaudoin. 2006. "Le premier Sommet de la Francophonie." In Histoire des relations internationales du Québec, Montréal: VLB éditeur, 141-149.

Parent, Alphonse-Marie. 1965. Rapport de la Commission royale d'enquête sur l'enseignement dans la province de Québec.

Parlament de Catalunya. 2012. "Proposta text transaccional per al ple monogràfic sobre el 
pacte fiscal." http://file01.lavanguardia.com/2012/07/25/54330073859-url.pdf (February 6, 2012).

Parti progressiste-conservateur du Canada. 1984. "Guide de la campagne." http://www.poltext.capp.ulaval.ca/upload/can1984pc_plt._14112008_181934.pdf (May 3, 2013).

Parti Québécois. 2011. "Agir en toute liberté. Programme du Parti Québécois." http://pq.org/parti/publications (December 3, 2012).

Partido Popular de Cataluña. 2010. "Sánchez-Camacho: "Defendemos la Catalunya real, el bilingüismo en libertad y el orgullo de ser catalanes y de ser españoles"." Es mucho lo que nos une. http://www.ppcatalunya.com/catala-sanchez-camacho$\% \mathrm{E} 2 \% 80 \% 9$ Cdefensem-la-catalunya-real-el-bilinguisme-en-llibertat-i-1 $\%$ E2\%80\%99orgull-de-ser-catalans-i-de-ser-espanyols\%E2\%80\%9D/ (March 18, 2011).

Pelletier, Réjean. 2008. Le Québec et le fédéralisme canadien: un regard critique. Québec: Presses de l'Université Laval.

Pellicer, Lluís, and Miquel Noguer. 2012. "El Estado deja a Cataluña sin los 219 millones por infraestructuras pendientes." El Pais. http://elpais.com/m/ccaa/2012/04/03/catalunya/1333450394_349666.html (February 6, 2013).

Piñol, Àngels, and Carlos E. Cué. 2012. "Mas se prepara para las elecciones tras la negativa de Rajoy al pacto fiscal." $E l$ País. http://politica.elpais.com/politica/2012/09/20/actualidad/1348131201_261707.ht ml (February 6, 2013).

Plourde, Michel, and Pierre Georgeault. 2008. Le français au Québec: 400 ans d'histoire et de vie. Montréal: Fides.

Pou Pujolràs, Agusti. 2002. "Legislació lingüística i procés de normalització: el cas català a l'Estat espanyol." http://www.ciemen.org/mercator/Menu_nou/index.cfm?lg=gb (December 3, 2010).

Québec. 1969. Act to promote the French Language in Québec.

-1974. Official Language Act.

—.1977a. Charte de la langue française.

—. 1977b. Charter of the French Language.

—1996. Le français langue commune. Enjeu de la société québécoise. Bilan de la 
situation de la langue française au Québec en 1995. Rapport du comité interministériel sur la situation de la langue française. http://www.cslf.gouv.qc.ca/publications/PubK103/K103.html\#Table (September 17, 2009).

-2000. An Act respecting the exercise of the fundamental rights and prerogatives of the Québec people and the Québec State.

- 2002. An Act to amend the Act respecting the Ministère des Relations internationales and other legislative provisions.

Quílez, Raquel. 2005. "Evolución de la ley. 1970-2005: De la emigración a la inmigración." Especial Inmigrantes, en busca de futuro. http://www.elmundo.es/especiales/2005/02/sociedad/inmigracion/ley/ley2.html (June 13, 2012).

Radio-Canada. 2011. "Le mouvement souverainiste en crise: Est-ce la fin d'une époque?" http://www.radio-canada.ca/nouvelles/Politique/2011/08/25/003souverainistes-experts.shtml (August 3, 2012).

—. 2012. "Québec veut resserrer la loi 101, mais ne touche pas aux cégeps." http://www.radio-canada.ca/nouvelles/Politique/2012/12/05/001-quebec-loi101decourcy.shtml (February 5, 2013).

Redacción. 2012. "La propuesta del pacto fiscal, aprobado por el 82,5\% de los votos." $L a$ Vanguardia.

http://www.lavanguardia.com/politica/20120725/54330089520/propuesta-pactofiscal-aprobado-82-5-votos.html (February 6, 2013).

Reitz, Jeffrey G. 2004. "Canada: Immigration and Nation-Building in the Transition to a Knowledge Economy." In Controlling Immigration. A Global Perspective, Stanford, California: Stanford Univ Press, 96-133.

Rémillard, Gil. 1986. “Allocution prononcée par le ministre délégué aux Affaires gouvernementales canadiennes, monsieur Gil Rémillard, à l'occasion du colloque "Une collaboration renouvelée du Québec et de ses partenaires dans la confédération"."

Rioux, Christian. 2006. "Oui catalan à $74 \%$, La Catalogne officiellement reconnue comme «nation»." Le Devoir: A1.

Robert, Jean-Claude. 2008. "La langue, enjeu politique du Québec." In Le français au Québec: 400 ans d'histoire et de vie, Montréal: Fides, 679.

Robic, Louise. 1987. “L’expérience québécoise.” Les Cahiers de droit 28(3): 575-584. 
Rocher, François, and André Lecours. 2007. "Le fédéralisme comme mode de gestion de la diversité : les cas du Canada et de l'Espagne." Éthique publique 9(1): 56-68.

Rocher, Guy. 2008. "La politique et la loi linguistiques du Québec en 1977." In Le français au Québec: 400 ans d'histoire et de vie, Montréal: Fides, 679.

Roller, E. 2004. "Conflict and cooperation in EU policy-making: The case of Catalonia." Perspectives on European Politics and Society 5(1): 81-102.

Romero, Belén Agrela. 2001. "Politiques d'action sociale auprès de la population immigrante étrangère en Espagne: approximations du schéma d'intervention à partir du travail social." Nouvelles pratiques sociales 14(1): 183-207.

Romero Valiente, Juan Manuel. 2004. Migraciones. Madrid: Instituto Nacional de Estadística. http://www.ine.es/ss/Satellite? $\mathrm{L}=0$ \&c $=$ INEPublicacion_C\&cid=1259924959283\&p=1254735110672\&pagenam $\mathrm{e}=$ ProductosYServicios\%2FPYSLayout\&param1=PYSDetalleGratuitas (November 11, 2011).

Royal Commission on Bilingualism and Biculturalism. 1965. A preliminary report of the Royal Commission on Bilingualism and Biculturalism. Ottawa.

Russell, Peter H. 1982. Leading constitutional decisions: cases on the British North America Act. Ottawa: Carleton University Press.

Sallon, Hélène. 2012. "Artur Mas enregistre un revers aux élections anticipées en Catalogne." Le Monde.

Saura, Joan. 2006. Un Nou Estatut de Catalunya per a una Espanya federal. Barcelona: Generalitat de Catalunya, Departament de Relacions Institucionals i Participació.

Secrétariat à la politique linguistique. 2009. "Dynamique des langues en quelques chiffres :

Tableaux."

http://www.spl.gouv.qc.ca/documentation/rapportssondagesstatistiques/dynamiqu edeslangues/tableaux/ (August 3, 2012).

Sharp, Mitchell, Secretary of State for External Affairs. 1968. Federalism and International Conferences on Education, A Supplement to Federalism and International Relations. Ottawa: Queen's Printer and Controller of Stationery.

Smith, Anthony. 1993. National Identity. Reno, NV: University of Nevada Press.

Statistics Canada, R.D. Fraser. 2008. "Statistiques historiques du Canada: Section B : Statistique de l'état civil et santé." Section B : Statistique de l'état civil et santé. http://www.statcan.gc.ca/pub/11-516-x/sectionb/4147437-fra.htm (April 27, 2012). 
Stroobants, Jean-Pierre. 2011. "Belgique: Wouter Beke, démocrate chrétien flamand, nouveau médiateur." Le Monde.

http://www.lemonde.fr/europe/article/2011/03/03/belgique-un-democratechretien-flamand-nomme-mediateur_1487676_3214.html (August 22, 2012).

Thiesse, Anne-Marie. 2001. La création des identités nationales: Europe, XVIIIe-XIXe siècle. Paris: Seuil.

Torregrosa, Iñaki Pardo. 2012. "La reunión de Rajoy y Mas por el pacto fiscal, en directo." La Vanguardia. http://endirecto.lavanguardia.com/politica/20120919/54350789687/reunion-rajoymas-pacto-fiscal.html (February 6, 2013).

Tribunal Constitucional. 1986. Sentencia Tribunal Constitucional núm. 83/1986 (Pleno), de 26 junio Recurso de Inconstitucionalidad número 517/1983.

—. 1989a. Sentencia 137/1989.

. 1989b. Sentencia 153/1989.

1993. Sentencia 80/1993.

1994 .

Sentencia

$165 / 1994$.

http://www.boe.es/aeboe/consultas/bases_datos/doc.php?

coleccion=tc\&id=SENTENCIA-1994-0165 (May 6, 2011).

—. 2008. "Tribunal Constitucional - Composición y organización." http://www.tribunalconstitucional.es/fr/tribunal/composicionorganizacion/Pages/C omposicionOrganizacion.aspx (April 25, 2013).

—. 2010. Sentencia 31/2010, de 28 de junio de 2010. http://www.tribunalconstitucional.es/fr/jurisprudencia/Pages/Sentencia.aspx? cod $=9873$ (October 25, 2010).

Turp, Daniel. 2006a. "L'Accord Canada-Québec sur l'UNESCO: Le sacrifice de l'autonomie internationale du Québec." Le Devoir: A7.

. 2006b. "La doctrine Gérin-Lajoie et l'émergence d'un droit québécois des relations internationales." In Les relations internationales du Québec depuis la Doctrine Gérin-Lajoie (1965-2005): le prolongement externe des compétences internes, Québec: Presses de l'Université Laval, 49-77.

2010. "Statut d'autonomie de la Catalogne - Un ordre constitutionnel imposé, comme au Québec." Le Devoir. http://www.ledevoir.com/international/actualitesinternationales/292666/statut-d-autonomie-de-la-catalogne-un-ordreconstitutionnel-impose-comme-au-quebec (November 3, 2012). 
United Kingdom. 1867. "Constitution Act, 1867.” Justice Laws Website. http://oislaws.justice.gc.ca/eng/Const/index.html (July 11, 2013).

Urgell, Jaume. 2003. "Introducció i anàlisi de la política exterior catalana." In Donar protagonisme a Catalunya: Acció internacional i política de relacions exteriors catalana, Barcelona: ECSA, 11-34.

Vaillancourt et al. 2007. "Laggards No More the Changed Socioeconomic Status of Francophones in Québec.” CD Howe Institute. Backgrounder, No. 103.

Vastel, Marie. 2012. "Résident permanent: un statut menacé?" Le Devoir. http://www.ledevoir.com/politique/canada/343758/residant-permanent-un-statutmenace (June 11, 2012).

Vázquez, Ángeles. 2007. "1.009 días con el mandato caducado.”. Público. http://www.publico.es/espana/337539/1-009-dias-con-el-mandato-caducado (May $21,2013)$.

Wallerstein, Immanuel. 1991. "The Construction of Peoplehood: Racism, Nationalism, Ethnicity." In Race, Nation, Class: Ambiguous Identities, New York: Verso, 71-85.

Wendt, A. 1999. Social theory of international politics. Cambridge: Cambridge Univ Press.

Woehrling, José. 2008. "La Charte de la langue française: les ajustements juridiques." In Le français au Québec: 400 ans d'histoire et de vie, Montréal: Fides, 679.

— 2009. "La Charte canadienne des droits et libertés et ses répercussions sur la vie politique." In Le parlementarisme canadien, Québec: Presses de l'Université Laval, 89-128.

Young, Margaret. 1991. L’immigration: l'Accord Canada-Québec. Ottawa: Gouvernement du Canada. http://dsp-psd.pwgsc.gc.ca/CollectionR/LoPBdP/BP/bp252-e.htm (March 21, 2011).

Zapata-Barrero, Ricard. 2006. "Immigration, autonomie politique et gestion de l'identité : le cas de la Catalogne." Outre-Terre 4(17): 189-209.

_. 2009a. "Building a Public Philosophy of Immigration in Catalonia. The Terms of Debate." In Immigration and self-government of minority nations, Diversitas, Bruxelles: Peter Lang, 125-161.

- 2009b. Immigration and self-government of minority nations. Bruxelles: Peter Lang. 